\title{
DGMPINAW ARTI
}

\section{6.}





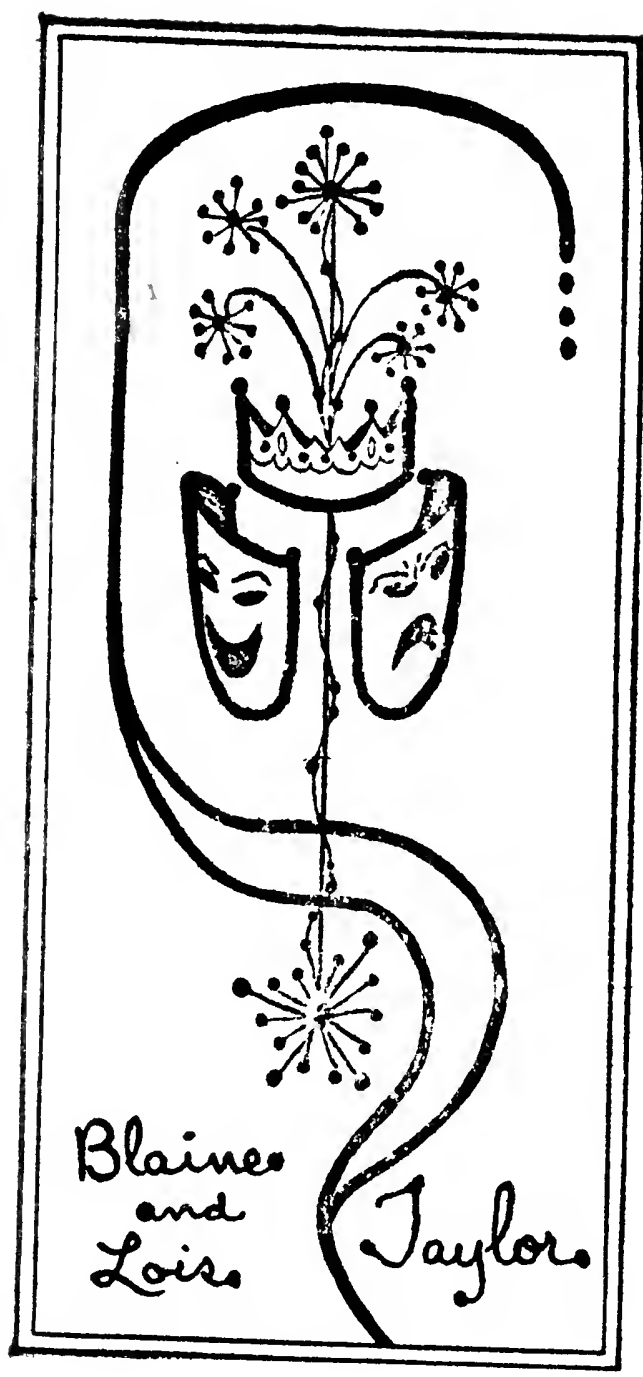



EGYPTIAN ART 




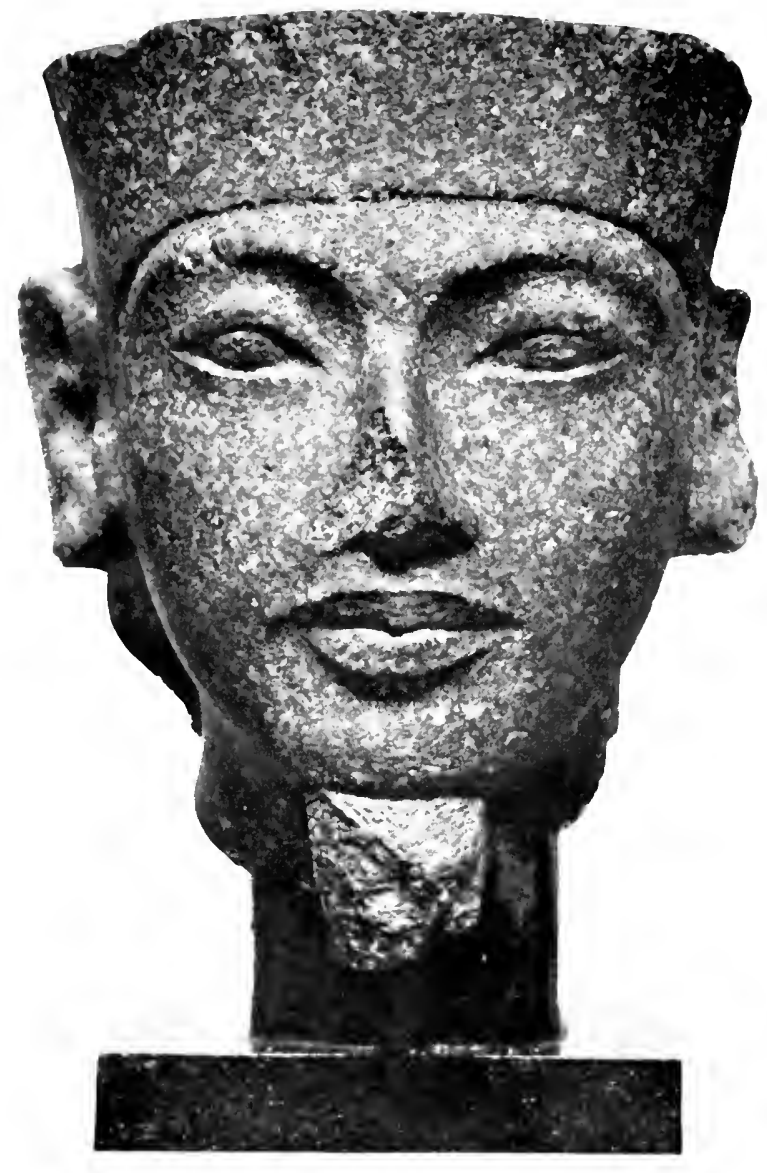

THE GOD AMEN

GRANITE HIEAD OH THL XVIIth D) NAST

MESELS ROYAYX IUL CINOUANTENAIRE, BRISSIIS 


\title{
EGYPTIAN
}

\section{INTRODUCTORY STUDIES}

BY

\section{JEAN CAPART}

Corresponding Member of the Royal Academy of Belgium; Chargé de Cours d'Egyptologie a l'Université de Liége

Professor a l'Institute Supérieur d'Art et d'Archoologie de l'Université de Liége;

Conservateur et Secrétaire des Musées Royaux de Cinquantenaire, Bruxelles

\author{
TRANSLATED FROM THE FRENCH \\ BY \\ WARREN R. DAWSON
}

NEW YORK

FREDERICK A. STOKES COMPANY

PUBLISHERS 


\section{(All rights resericd)}

Printed in Grat Britain by

UNWIN BROTHERS, LIMITED, IHE GRESHAM PRESS, LONDON AND WOKING 


\section{TRANSLATOR'S PREFACE}

HE following pages contain a translation of the introductory chapters of Monsieur Capart's Legons sur 1 l'Art égyptien. ${ }^{\mathrm{I}}$ Some few remarks are necessary to explain the origin of the work, and also of this partial translation.

In 1903 the University of Liège introduced a course of ancient art and archæology, and a similar course of study was at the same time instituted in Brussels, Monsieur Capart being appointed professor at both places. For the purpose of his lectures he drew up a series of studies embracing the entire range of Oriental art in which the predominating influence was naturally Egyptian. The practical experience gained over a number of years resulted in considerable additions and modifications to the original scheme, which benefited by each successive improvement. Monsieur Capart's wide knowledge and experience, coupled with the unrivalled series of documents which he has amassed, should form a basis for a more comprehensive study of ancient Oriental art than has ever been attempted hitherto.

In 1914 the war brought these academic courses to a standstill, but fortunately it was found possible to resume them in 1916, but in a more condensed form. These we now have in the Legons. The post-war difficulties of publication made it impossible for the author to produce a fully illustrated and annotated volume, but he was fortunately prevailed upon to issue the text as a provisional edition

I Liège: Imprimerie H. Vaillant-Carmine. I 920. 
without illustrations or notes, until such time as it should become possible to fulfil his original intentions.

On studying the Lefons I was immediately struck by a conspicuous difference in plan between them and the existing works on Egyptian art. The latter, many of them excellent books, are really little more than catalogues of known works of art arranged in chronological order, or disconnected studies of special points. No other work known to me has ever probed so deeply into the question of origins and of motives, or has been based upon such thoroughly evolutional lines as Monsieur Capart's book. I realised what a boon could be conferred upon Englishspeaking readers if it could be made accessible to them. Unfortunately the scanty leisure hours which an active business life leaves at my disposal made a translation of the whole book out of the question, but I suggested to Monsieur Capart that an illustrated English edition of the introductory chapters alone would be generally welcomed. He kindly assented to the proposal, and has revised the text chapter by chapter and added the bibliographical notes. These latter, which are for the benefit of students, have been collected at the end of each chapter, so as not to encumber the text with footnotes.

In selecting the illustrations for this work it has been our aim as far as possible to avoid the unnecessary duplication of including pictures of subjects already well known and reproduced in Monsieur Capart's previous books or in the works of others, except in cases where their presence is absolutely necessary to the correct understanding of the text. A wealth of illustrations will be found particularly in the author's Primitive Art in Egypt and in L'Art Egyptien, a new edition of which has recently appeared.

I have only to add that I have made a perfectly literal translation of the French text, and have subordinated all literary considerations to absolute clearness. In the tran- 
scription of proper names I must accept full responsibility for many inconsistencies, for instead of adhering to any one system, I have used those names which are best known to general readers or those which were used by the original discoverers or editors of the monuments.

Finally, I must express my thanks to the author for his ever-ready assistance, and to him as well as to the publishers for their patient toleration of delays which were, however, beyond my control.

WARREN R. DAWSON. 



\section{CONTENTS}

CHAPTER I

PAGE

THE COUNTRY : ITS CHARACTERISTIC ASPECTS

CHAPTER II

THE FRAMEWORK OF HISTORY .

CHAPTER III

PRIMITIVE UPPER EGYPT . . . . . . 45

CHAPTER IV

THE FIRST PHARAONIC MONUMENTS . . . $5^{6}$

CHAPTER V

ARCHITECTURAL HIEROGLYPHS AND KINDRED SUB-

'EC'TS .

CHAPTER VI

MATERIALS AND ELEMENTS OF BUILDING . $\quad 89$

CHAPTER VII

FUNDAMENTAL FORMS IN ARCHITECTURE . . 104

CHAPTER VIII

FUNDAMENTAL FORMS IN ARCHITECTURE (continued) • II7

CHAPTER IX

CONCERNING COLUMNS AND THE TRANSPOSITION OF THE FORMS PROPER TO ONE MATERIAL INTO ANOTHER . 
10 EGYPTIAN ART

CHAPTER $\mathrm{X}$

THE CONVENTIONS OF EGYPTIAN DRAWING .

CHAPTER XI

THE ARTISTIC IDEAS OF THE EGYPTIANS

.160

INDEX 


\section{ILLUSTRATIONS}

with references to the pages in text wherein they are described or referred to.

PLATE PAGE

I. Stele of the Serpent King . . . . . . 34 (After BÉnédite: Monuments Piot.)

2. Panels of Hesi . . . . . . . . 34 (After Mariette: Album du Musée du Boulaq.)

3. Reconstruction of the Pyramids of Kheops and KHEPHREN • $\cdot$ • (After HöLscher: Das Grabdenkmal des Königs Chephren.)

4. Pectoral of Sesostris III from Dashur - 36 (After photographs by BRUGSCH-PACHA.)

5. Façade of the Tomb of Chnumhotep II at Beni Hasan . . . . . . . . . 36 (After MarietTe: Voyage dans la Haute Egypte.)

6. Portico of Anubis in the Temple of Deir-el-

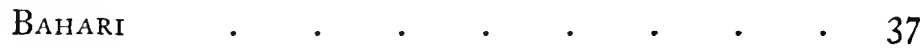
(After a photograph by Dr. C. MATHIEU.)

7. Columns in the Tomb of Ay at Tell-el-Amarna 37 (After Les Monuments du Culte d'Atonou.)

8. Arm-chair of the XVIIIth Dynasty . . 39 (After Borchardt : Kunstwerke .... Museum zu Kairo.)

9. Passage in the Temple of Horus at Edfu, showing the Gargoyles . • • • • • . . 40 (After a photograph by H. BÉcharD.)

I0. The Royal Tomb of Nagada as restored by De Morgan · • • • • • • • •

(Drawn by J. SÉDILLOT after DE MORGAN: Recherches sur les Origines de l'Egytte.) 
PLATE

i i. Central Court of tile Pyramid-Temple of Sauure AS RESTORED BY BORCHARDT . . . . 67

(After Borchardt: Das Grabdenkmal des Königs Sahure.)

12. Pronaos of the Temple of Horus at Edfu

(After a photograph by H. BÊCHARD.)

13. Architectural Hieroglyphs - $\cdot$ -
(Draun by J. Sédillot after Davies: The Mastaba of Ptahhetep.)

14. Light Canopy in the Royal Tomb at Tell-elAmarna . . . . . . . . .

(Draun by J. SÉDILlot after Les Monuments du Culte d'Atonou.)

15. Storehouses of the Temple at Tell-el-Amarna -

(Drawn by J. SÉDILLOT after DAvies: The Rock Tombs of ElAmarna.)

16. Door-frame in the Hathor Sanctuary at DeirEL-BAHARI . . . . . . .

(Drawn by J. SÉDILLOT after NAVILLE : The Temple of Deir-elBahari.)

17. The Ornamented Stele of Ptah-hetep

(After Davies: The Mustaba of Ptah-hetep.)

i 8. The Simple Stele of Ptah-hetep (After Davies : op. cit.)

19. The Sarcophagus of King Mycerinus

(After Prisse D'Avennes: Historie de l'Art Egypticn.)

20. Imitation of Mat-work and Woven Fabrics on THE STELE OF Hesi .
(After Quibell: The Tomb of Hesy.)

2i. Funerary Shrine of Princess Sadhe at Deir-elBAHARI

(Drawn by J. SÉDILLOT after NAville: The XIth Dynasty Temple of Deir-el-Bahari.)

22. Funerary Shrine of Princess Aashait at Deir-elBAHARI

(Drawn by J. SÉDILLOT after NAville: op. cit.)

23. Brick Vaulting of IIIRd Dynasty.

(After Garstang: The Tombs of the Illrd Egyptian Dynasty.)

24. Cilapel of Anubis at Deir-el-Bahari . . . 
PLATE

25. Windows in the Hypostyle Hall at Karnak 98 (Photograph by J. CAPART.)

26. The Great Temple of Horus at Edfu

(Photograph by H. BÉCHARD.)

27. Propylon of the Temple of Khonsu at Karnak - io6 (After MarietTe: Voyage dans la Haute Egypte.)

28. Second Hypostyle Hall of the Temple of Seti I AT ABYDOS

(Photograph by J. CAPART.)

29. Section of the Temple of Hathor at Dendera - io7 (After Mariette: Denderah.)

30. Vestibule of the Temple of Khephren-Upper PART . . . . . . . . . 108

(After JÉQUIER: Les Temples memphites et thébains.)

31. Granite Pillars in the Temple of Khephren at GIZEH • • • • • • • • • • • (Photograph by J. CAPART.)

32. Granite Pillars at Karnak, ornamented by FLORAL DEVICES • (Photograp.h by DR. C. Mathieu.)

33. Pillars in the Second Hypostyle Hall of Seti I

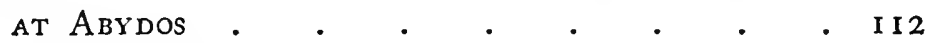
(After CAulfield: The Temple of the Kings.)

34. Tomb of Ameni-Amenemhat at Beni-Hasan • - II3 (Photograph by J. Garstang.)

35. Hathor Pillars in the Temple of Amenophis III AT EL Kab $\quad$. . . . . . . . II3 (After TYLOR: Wall Drawings and Monuments of El-Kab.)

36. Osirian Pillars from the Temple of Sesostris I

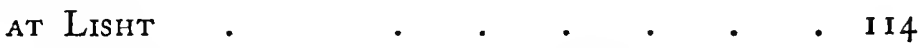
(After JÉQUIER: Les Temples memphites et thébains.)

37. Lotiform Columans represented by Paintings i 18 (Drarun by J. SÉdillot after PrISSE D'Avennes: Histoire de l'Art Egyptien.)

38. Lotiform Columins in an Ancient Empire relief in

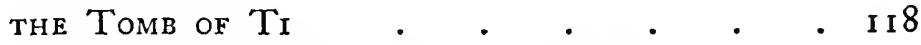
(After MARIETTE: Voyage dans la Haute Egypte.) 
39. Lotiform Colum from the Mastaba of PtahSHEPSHES

(After a photograph by BRUGSCH-PACHA.)

40. Fasciculated Papyriform Columes in the Temple OF Ne-USER-RE

(After BorchardT: Ausgrabungen bei Abusir.)

41. Typical Fasciculated Papyriform Columins of the

XVIIITH DYNASTY . . . • • . I II

(After Prisse D'Avennes: Histoire de l'Art Egyptien.)

42. Papyriform Columins of the Hypostyle Hall at

KARNAK

(After a photograph by BÉATO.)

43. Open-capitaled Papyriform Column from the Palace of Amenophis IV . . . .

(Drain by J. SÉDILLOT after PETRIE: Till-el-Amarna.)

44. Capital of Column in the Hypostyle Hall at KARNAK (After Lepsius : Denkmäler.)

45. Capitals of Cyperus Papyrus in the Hypostyle Hall AT ESNEH (After a photograph by BÉATO.)

46. Composite Floral Columns represented by Paint-

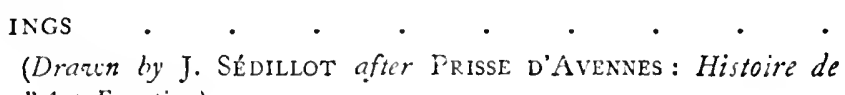
l'Art Egyptien.)

47. Portico of the Temple of Isis at Phile . 125 (After a photograph by BÉCHARD.)

48. Hypostyle Hall of the Dendera Temple (After a photograph by BÉATC.)

49. Theban Temple of Ptah at Karnak (Photograph by J. CAPART.)

50. Small Funerary Tents represented on a Bas-relief in the Berlin Museum (Photograph by the Graphische Gesellschaft of Berini;

5 I Erection of a Funerary Tent represented by a Basrelief in the Berlin Museum . . . . (Photograph by the Berlin Graphische (iesellschaft.) 
PLATE

52. Pillars at Zawiet-el-Maietin

(After Prisse d'Avennes: Histoire de l'Art Egyttien)

53. Granite Naos of Euergetes II and Cleopatra at Debod.

(After RöDER: Debod bis Bab Kalabsche.)

54. Theban House represented in the Tomb of NeferHOTEP • • • • • • • • • • I 37

(After RoselLinI : Monumenti civili.)

55. Hathor Cow of the Saite Period . • . I4I

(After Bissing-Bruckmann: Denkmäler ägyptische Skulptur.)

56. Ramesses VI immolating a Vanguished For I4I (After a photograph by BRUGSCH-PACHA.)

57. The Palace of Amenophis IV represented fullFACE . (Drawn by J. SÉdiLLoT after Davies: The Rock Tombs of El Amarna.)

58. The Palace of Amenophis IV represented from

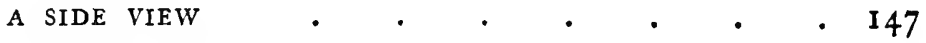

(Drazin by J. SÉDiLlot after Davies : op. cit.)

59. Painted Reliefs in the Tomb of Mer-ab

(After Lepsius : Denkmäler.)

60. Bangueting Scene from a Tomb-fresco in the

British Museum . . . . . . I5I

(After a photograph by MANSELL.)

6I. Ethiopians bringing Tribute: from The tomb of

Huy at Thebes

(After Lepsius: Denkmäler.)

62. Serdab containing Funereal Statues • . . 167 (After a photograph by JUNKER.)

63. Unguent-holders of the New Kingdom in the

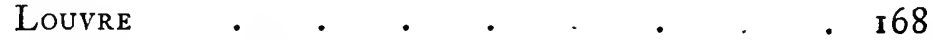

(After RAYET: Monuments et l'Art antique.)

64. Unguent-holder in the Liverpool Museum . I68 (Photograph by J. CAPART.) 



\section{EGYPTIAN ART}

CHAPTER I

\section{THE COUNTRY : ITS CHARACTERISTIC ASPECTS}

WHE natural introduction to lessons on Egyptian Art is a study, however summary, of the physical 1 conditions of the country.

Without exaggerating the influence of this medium upon artistic productions, it is nevertheless necessary to take into account the chief peculiarities of the Nile Valley, and to show in what respects this region essentially differs from almost every other land. (I)

It is not intended to repeat here the pages of a handbook of physical geography, (2) still less to transcribe the introductory paragraphs of a traveller's guide to Egypt, but rather to attempt to convey as succinct an impression as possible of the divers aspects of the Nile Valley, which, on the whole, has altered very little since ancient times.

Let us glance at a map of Egypt. Across the great desert regions of North-Eastern Africa the Nile forms a giant oasis, exceedingly elongated, which can be divided into two principal parts: the triangular estuary, called the Delta, and the course of the stream, which stretches far away towards the interior of Africa. The Delta is known as Lower Egypt, and the river proper, as far as the First Cataract, Upper Egypt.

Egypt is situated at the point of contact of three worlds : on its northern frontier it adjoins the eastern basin of the Mediterranean; on the eastern frontier of the Delta it 
touches Asia ; and, by the course of the river, it effects a penetration into African regions.

The natural frontiers of the north, the east and the west (Libyan or Sahara desert) have never changed, but that of the south, on the contrary, has reached farther and farther up the course of the Nile just as the power of the kings of Egypt has extended to remoter regions. The First Cataract, in the Assuan district, constitutes, however, in a general way the southern frontier of Egypt proper towards the south. The Pharaohs of the Ancient Empire rarely went beyond it : those of the Middle Empire conquered Lower Nubia; and later, Egyptian domination extended to Upper Nubia and even to the Sudan.

Descriptions of Egypt have often been written, by ancient travellers, Greek and Roman, by the Arabs of the Middle Ages, (3) and by countless writers in modern times. (4)

Let us first recall the brief and striking phrase by which Herodotus described Egypt as "a gift of the Nile." One might suppose that the Arab general, Amru, who conquered Egypt in A.D. 640 knew Herodotus' definition, and that he made a commentary upon it in his letter to the Kalif Omar: "O Prince of the Faithful, picture to yourself an arid desert and a magnificent country between two mountain-ranges: such is Egypt. All her products and all her riches from Assuan to Mencha come from the kindly stream which flows majestically amid the country. The time of the rise and of the ebb of its waters is so governed by the courses of the sun and the moon that there is one season of the year when all the elements of the universe come to pay to this King of Rivers the tribute with which Providence has endowed them for his benefit. Then the waters increase, leave their bed and cover the whole face of Egypt in order to deposit there the fertile mud. There is no communication between village and village save by means of boats, which are as numerous as palm-leaves. When at last the time comes when the waters cease to be necessary to the fertility of the soil, the docile river retreats within the banks which destiny has marked out for it, leaving the treasures which are hidden in the bosom of the 
earth to be gathered in. A people protected by Heaven, and who, like the bee, seem destined to work only for the benefit of others without profit to themselves of the fruit of the sweat of their brows, busily open up the earth's surface to sow there the seeds which will be fertilised by Him who makes the harvests grow and ripen. The germ develops, the shoot appears, the ear forms by the aid of the dew which takes the place of rain and which maintains the fruitful moisture with which the soil is charged: then sterility once more succeeds the most abundant of harvests. It is thus, $O$ Prince of the Faithful, that Egypt displays the picture, each in turn, of a dusty desert, a watery plain, a black and slimy bog, a verdant meadow, a garden decked with flowers, and a landscape covered with golden harvest." (5)

A modern scholar, Gaston Maspero, has given in his great work, The Dawn of Civilisation: Egypt and Chaldea, a precise description of the different aspects of the Nile. Few travellers have had occasion to traverse Egypt in all its nooks and corners in so thorough a fashion as Maspero, As Director-General of the Service of Antiquities it was his duty to examine personally the ruins and excavations. Each year he delighted to make a tour of inspection, which gave him the opportunity ever and again of seeing afresh these riverside scenes, thereby adding to and seasoning the impressions which he felt. This is why his testimony, particularly important as it is, enables us to lay aside the mass of other descriptions and to concentrate upon the principal features of his.

First, then, let us see how he characterises the two principal parts of Egypt. After having noted the three chief mouths of the Nile, which empty themselves into the sea and thus divide the Delta into two nearly equal sectors, Maspero expresses himself as follows : "These three great waterways are united by a tracery of artificial rivers and canals and by ditches, some natural, others dug by the hand of man, which silt up, close, open again and shift ceaselessly, ramifying into innumerable branches over the surface of the soil, spreading life and fertility broadcast. This network 
shrinks and becomes simpler as one proceeds southwards, the black earth and cultivation grow less, the tawny outline of the desert appears, the Libyan and Arabian hills rear themselves and come nearer together and restrict the horizon more and more, and, at the point where they may be said to unite, the Delta ends and Egypt proper begins. It is only a band of vegetable mould stretching from north to south between two regions of drought and desolation, an elongated oasis along the borders of the Nile, made and sustained by the Nile. Two ranges of hills, nearly parallel, hem it in and throughout its length, at an average distance of twelve miles apart." (5)

And now let us see his description of the stream itself and its banks: "It flows with a strong and even current under the black banks cut straight through the alluvial earth. There are little copses of date-palms, groups of acacias and sycomores, plots of barley or wheat, fields of beans or bersîm, here and there banks of sand which the slightest wind stirs up into clouds, and above all deep silence, scarcely broken by the cries of the birds or by the song of the oarsmen of a passing boat. . . The same landscape repeats itself again and again every day. Everywhere the same tree-clumps alternate with the same fields, growing green or parching in the sun, according to the season. The Nile unfolds its wandering course with the same motion amid the islets and its steep banks : village follows village at once smiling and dull beneath its canopy of leaves." (7)

This general view becomes more detailed as we examine different sites which show us successively the most characteristic aspects of the Egyptian landscape.

Let us first look at the course of the river itself, taking it from the point where it enters Egypt in the Assuan district near the famous Island of Philæ. The placid and still waters formerly made, before the construction of the Assuan barrage, a wonderful border around this little islet which is decked with the temples of the goddess Isis like a sacred barque floating in the midst of the stream. But now this beautiful site is bereft of the greater part of its charm. Soon, as it proceeds downstream from Philæ, the 
gathering momentum of the water hurls it headlong in a more and more rapid fall, and the stream makes its leap over several successive ledges; this is what we call the cataract. Were one to clamber up to the top of one of the rocky islets with which the river-bed is strewn, the horizon would be descried stretching away-vast and lowering.

On all sides the eye surveys nothing but islands and granite boulders, amongst which the waters thread their way, and only the scanty palm-trees impart life here and there to a scene which would otherwise be as barren as the desert.

Soon again, however, the river calms down, until, in the region of Elephantine, it has almost entirely regained its placidity. From here right down to the sea its current ebbs peacefully on, spreading out or contracting as it follows the profile of the valley. If in some places its breadth gives it the aspect of an arm of the sea, in others it quickly pulls itself in to the narrowness of a canal. Wherever the Nile is shallow it is parted ever and again by sand-banks which hinder shipping; and they must be rounded by means of the deep channel which flows immediately under one or other of the banks.

If, again, in several places, the river abuts directly on to the mountains, which may in places even assume the form of cliffs, the shores are more often flat and desolate, but dotted here and there by palm-groves.

Every year, from June to October, the inundation drives the river from its bed: that part of the valley which is under water and on which the mud is deposited-the mud with which the water is charged-constitutes what might be called the real Egypt in opposition to the desert.

We will now consider, at different points in the valley, the effect of this distinctive phenomenon.

If in the region of Assuan one moves some little distance from the river to the ruins of St. Simeon's Convent in the desert gorge, and from thence surveys the landscape, one would at once get there an aspect very typical of Egypt. In the dried-up valley a bed of sand spreads down to the river : on the left bank of the Nile the desert reigns supreme. 
On the right bank of the stream a narrow strip of ground is for the most part covered by the little town of Assuan. Immediately beyond, the Arabian desert reappears and stretches as far as the eye can reach. Here the valley is reduced to very small limits.

At Thebes, on the contrary, the plain opens out widely. The traveller stationed at Luxor on the right bank would see before him the river broad and calm, whilst on the left bank the foreshore, sloping up gently, is uncovered day by day as the inundation abates. A little beyond this sandy stretch, ill-fitted for cultivation, he would espy a black strip of muddy land, dotted with groups of trees, and beyond that again the desert range rears its mountain head.

If the traveller now stations himself on the lower slopes of these very mountains and at the extreme west of the valley, he will see the great Theban plain unfold before him in all its fullness. At his feet are the first slopes of the hills, riddled with excavations which are ancient tombs, with Arab dwellings dotted about here and there. Bordering on the desert the majestic ruins of the great temple of Ramesses II (known as the Ramesseum) rear themselves, while a little towards the right the two colossal statues of the so-called Memnon appear in sight, the two statues which stood before the funerary temple of Amenophis III. An irrigation canal, as a narrow glittering band, forms the background of the picture as it crosses the plain diagonally on its way to the Nile. Beyond the river a straight black strip marks out the cultivated area on the right bank, and finally the mountains of the Arabian desert rise up to the very horizon, where they are partly lost to view.

Nor is the view very different if one moves one's position to the apex of the Delta, from such a point as the heights of the great necropolis of Saqqara and Abusir.

The problem before the population of Egypt from the earliest times has ever been to extend to the fullest possible limits the benefits of the inundation, to subdue the desert territory, ever too vast, by preventing the sand from ravaging what the farmers have won and which they owe to their 
labours in irrigation: and the modern engineer merely continues, in a sense, the traditions of the most ancient inhabitants of the land. One result deserves special mention, and that is that the Egyptians, begrudging the loss of the smallest part of this precious land, have relegated to the desert the buildings consecrated to the cult of the dead.

Having thus considered the river and its valley, we must take a rapid glance at the cultivation and the handiwork of the inhabitants.

In Lower Egypt the plain stretches away to infinity. Rich in harvests most abundant, but wearying to the eye, fields follow on fields, enlivened by groups of palm-trees and now and then by a wood. From tract to tract, village follows on village, consisting usually of a handful of dwellings, linked up by roadways overshadowed by trees, and at a level scarcely higher than that of the neighbouring cultivation. Canals, branching ever more and more, wind throughout, some, fairly broad, lapping lazily amongst the groves of palm-trees, whilst others, narrower, glide like little brooks across the villages.

Various hydraulic devices, besides, make it possible to raise the water from the canals and to spread it over the land. The simplest of these is called the shadouf, and is a kind of balance, with a counterweight which lifts a receptacle full of water to a raised trench into which the labourer who works the machine deftly turns it. The shadouf is an extremely ancient invention, for it figures on the monuments of Pharaonic times. (8)

Let us now consider some typical landscapes in the cultivated districts of Upper Egypt. The picturesque village of Kafr el Haram groups its houses at the foot of the plateau of Gizeh, upon which the great pyramids rear themselves : beyond, as far as the eye can reach, extends the plain, dappled with great pools of water left behind by the retreating inundation. In the distance another village hides itself beneath a group of palms.

When one goes from the station at Bédrechein to the Saqqara necropolis, the region of Mit-Rahine is first 
crossed, whose rich crops spread away as far as the eye can reach. At the very foot of the mountain the village of Saqqara, which has given its name to the whole district, abuts on a great marsh where geese and ducks sport.

The outlook changes but little in the different tracts of Middle Egypt. In the Abydos district, for instance, from the Nile right up to the mountains one crosses wonderfully fertile lands, which show as the inundation retreats a heavy mould which dries up and cracks in all directions under the rays of the sun. This dark-coloured soil contrasts sharply with the light tones of the desert sand, and when the ancient Egyptians called their country "the Black Land" they certainly hit upon its most noticeable characteristic.

The cultivated land passes into desert very suddenly, almost without any intermediate change. One cannot, however, help noticing the great trees which thrive vigorously on bare sand, as though they stood as a protest against sterility, although their deep-set roots burrow down to levels reached by infiltrated water.

The desert merges really into the mountain, or rather into the two chains of mountains which divide off the course of the river. The Libyan range follows the left bank, just as the Arabian follows the right. Towards Lower Egypt the desert is flat and monotonous, rolling away in sanddunes for mile after mile. At the rainy season a sparse vegetation marks out the routes on which the caravans depend for feeding their beasts of burden. Towards Upper Egypt the desert rises often into gentle slopes up to the point where it reaches the mountains, and then it rises quite steeply, often in terraces. The necropolis of Abydos offers a very good instance of this. On all sides, at the lowest level, the soil is ploughed up and tossed about, laying bare beneath this mantle of sand the mouths of the shafts which give access to the funereal chambers below. The horizon is shut out by the mountain, which rears itself several hundred feet above the plain, a great solid mass with little variation in its outline. At Thebes, on the other hand, the contours are more varied, the successive slopes 
of the hills are more sharply cut; above them a peak towers up, reminding one of a natural pyramid, the "Peak of the West" as the ancients called it. (9) The action of the sand, blown about by the wind, has cut capriciously into the limestone, as for instance above the famous temple of Deir-el-Bahari.

The mountain-chain breaks up at times suddenly, giving access to a desolate valley : the best-known if not the most typical case of this is the Valley of the Kings at Thebes. Its long and winding course gives some extremely picturesque glimpses, recalling at times the primeval chaos of the valley. At one point the ancient Egyptians have cut through the foundations of a natural amphitheatre in the mountains, where they excavated the last resting-places of the great monarchs of the New Empire. Here, at the foot of a sheer cliff, at the end of a spur of gigantic rocks in steep defiles, the sovereigns who had brought under their sway the whole of the world known in their days slept their last sleep. In another valley, not so wild in its aspect, are hewn the tombs of their queens and their princes.

As far as the neighbourhood of Gebel-Silsileh the mountains are of limestone. Here a bank of compact sandstone is encountered, and the Nile has cut for itself a pathway through the stone, reducing the size of the valley to that of its own breadth. The banks are cut up by great excavations which mark the site of ancient quarries. In the Assuan region we have seen how the river has forced a road amid the granite boulders : at times the blocks have been rolled along and lean one on another as if Titans had piled up there an armoury of stones of different sizes from which were to be selected the materials for the building of the royal monuments.

Thus we have come across the principal materials used in the great building operations of antiquity: limestone, sandstone and granite, which the architects made use of in the manner we shall presently see.

Finally we must draw attention to the element which has played the fundamental rôle in the architecture of Ancient Egypt-the Nile mud. The inhabitants find it 
everywhere ready to hand. Still moist from the inundation they dug it, sometimes mixing it with chopped straw to give it greater consistency, they moulded it into blocks of even size, arranged in rows on the ground, where the rays of the sun quickly imparted sufficient firmness to make it usable at once for building.

And to this day one sometimes comes across a native brickworks near the borders of the desert where the blocks of mud are laid out in straight lines on the ground to be dried by the sun : or again, on the very banks of the river, one may see at once the bank from which the material has been taken, the bricks drying, the dried bricks piled in stacks, and finally the native houses which have retained under the mason's hand the same form which has come down from long-past ages.

\section{BIBLIOGRAPHY.}

I. Schrader, F., Les Origines planetaires de l'Egypte, in the Revue de l'Ecole d'anthropologie de Paris, January 1909, pp. I 5-27.

2. Reclus, E., Nouvelle Géographie Universelle, t. x. L'Afrique Septentrionale, Ist Part, Bassin de Nil. Paris, Hachette, I 885.

3. Reitemeyer, Else, Beschribung Ägyptens in Mittelalter aus den geographischen Werken der Araber. Leipzig, 1903.

4. An idea will be gained by consulting, for instance, Lumbroso, G., Descrittori iraliani dell' Egitto e di Alessandria in the Memorie della reale Accademia dei Lincei, Rome, I 879, a work completed in 1892 under the title Ritocchi e aggiunte ai descrittori italiani dell' Egitto e di Alessandria.

5. Translation from that given in the introduction to Palmieri and Béchard's Album L'Egypte et la Nubie. Paris, 1887.

6. Maspero, G., The Dawn of Civilisation, $5^{\text {th }}$ edition, London, I910, p. 6.

7. Ibid., pp. 7-9.

8. Scheil, V., Le Tombeau d'Apoui, in the Mémoires de la Mission archéologique francaise du Caire, t. v., 1894, Pp. 607-8 and pl. II.

Wilkinson-Birch, Monners and Customs of the Ancient Egyptians, London, I 878 , t. iii., p. 28 r.

9. Maspero, G., La Déesse Miritskro et ses guérisons miraculeuses, in the Etudes de Mythologie et d'Archéologie égyptiennes, t. ii., pp. 402-10.

Erman, A., La Religion égyptienne. Paris, 1907, Pp. I I2-I3.

Capart, J., Une Déesse thébaine-Miritskro, Bruxelles, I901. Extract from the Revue de l'Université de Bruxelles, t. vi., I900-I, April. 


\section{CHAPTER II}

\section{THE FRAMEWORK OF HISTORY}

THE Egyptians have bequeathed to us but scanty traces of their historical records. We know, however,

1 that from the earliest times they were wont to record important events in their history: indeed, there was even a special goddess relegated to preside over the annals of the Empire, (I) but only a few fragments have come down to us.

The document known as the "Palermo Stone" and some kindred fragments preserved at Cairo were drawn up under the Ancient Empire, and give us a table of the regnal years of certain kings and an indication of the most important events of those reigns. (2) Unfortunately, the fragments which have survived make up but a small part of the original text. Next must be mentioned a list of kings drawn up under the New Empire and known as the Turin Papyrus, but which is hopelessly mutilated. (3)

Some monumental lists have also been recovered: two at Abydos, one at Saqqara, and one at Karnak. Several series of royal names are inscribed upon them, but they were drawn up in connection with certain phases of religious worship ; whole periods are passed over without being represented by a single king. (4)

Manetho of Sebennytos, an Egyptian priest who was contemporary with the first two Ptolemies, wrote a history of Egypt, in compiling which he drew upon Egyptian sources of information. His work is unhappily lost, and nothing now remains but some fragmentary lists of sovereigns. The most important fragments have come down to us in Josephus' Contra Apionem. The table of dynasties, 
in three books, is preserved in the works of the Christian historians (Julianus Africanus, Eusebius, and Georgius of Syncella), but unfortunately with serious alterations in the names and dates. (5)

Manetho had classified all the kings of Egypt into a number of dynasties, but the conception of the dynasties lacks precision. One might suppose, however, that the dynasties took their names from those of the towns which served as capitals, or from which the reigning families traced their origin.

The list of towns is as follows: Thinis, Memphis, Elephantine, Heracleopolis, Thebes, Xoïs, Tanis, Bubastis, Saïs, Mendes, and Sebennytos. The dynastias thus received the following nomenclature :-

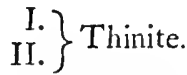
IIV. $\}$ Memphite.
V. Elephantinite.
$\left.\begin{array}{r}\text { VI. } \\ \text { VII. } \\ \text { VIII. }\end{array}\right\}$ Memphite.
IX.
$X$. Heracleopolitan.
XI.
XII. Theban.
XIII.
XIV. Xoïte.
XV. Hyksos and Theban.
XVI. Hyksos.
XVII. Hyksos and Theban.
XVIII. ?
XIX. Theban.
XX.
XXI. Tanite and Theban.
XXII. Bubastite.
XXIII. Tanite.
XXIV. Saïte.
$X X V$. Ethiopian and Saïte.
XXVI. Saïte.
XXVII. Persian.
XXVIII. Saite.
XXIX. Mendesian.
XXX. Sebynnite.
XXXI. Persian.

In the framework thus built up, it next remains to classify the kings whose names have been found upon the monuments. One is helped in this endeavour in several ways : first by direct identification of the Egyptian names and those mentioned by Manetho; thus Khufu was Kheops, Khafra was Khephren, Ramessu was Ramesses. The Egyptian documents furnish us with the names of successive kings, sometimes in genealogies, for instance. At some periods, too, the reigning king was wont to associate his successors with him upon the throne, and the monuments which bear the double names establish the order of succession. In several tombs of the Ancient Empire, names of 
funerary domains are often given in connection with the kings who founded them, which makes it possible for us to make deductions as to the grouping and often as to the succession of the kings. (6) In this connection also mention may be made of the biographical inscriptions which relate, for instance, how an officer enlisted under one king, obtained promotion under another, gained distinction under a third, etc.

These researches into the classification of the kings mainly occupied the generation of historians which preceded us. Their labours have enabled us to readjust a great number of royal names in Manetho's table of dynasties.

Can one compile, at the present day, a true history of Egypt, especially of the most ancient times? Information derived from the monuments, despite the great abundance of the latter, is, after all, of a very fortuitous nature. "For one ancient papyrus which has been rescued, countless millions must have perished. . . . It would seem that there still exists a great abundance of Egyptian documents, but they have to cover an enormous space of time." (7) We can generally say that such and such a king carried out building operations upon such and such a temple; that he undertook a military expedition against such and such a neighbouring country; that he returned with the spoils which he proudly enumerates; to which we may add a more or less lengthy catalogue of the monuments which his contemporaries have left behind them.

One may see in the histories of Wiedemann and of Petrie (8) very full lists which will give some idea of the data which have accumulated, little by little, around the names of each of the kings, but most often without affording us the slightest clue to a due conception of the main lines of contemporary history. Our knowledge of the civilisation of Egypt is much fuller, thanks to the biographical inscriptions and to the countless scenes depicted upon the temples and the tombs. One can see the use which historians have made of this material in glancing through the great works of Maspero, Edward Meyer and Breasted. (9)

We must also allude to another important source of 
information, although the most difficult to use-the religious texts. These appear to us, from the times of the Ancient Empire, as the written version of a long and almost invariable oral tradition. They indicate to us a state of civilisation which Egypt had long since left behind, when these religious texts were used. The general impression which emerges from a scrutiny of these materials is that even the Egypt of the earliest dynasties had already a long past behind it.

Without summarising here the main lines of Egyptian history, which will be found fully worked out in the books just mentioned, we must, however, define the meaning of a certain number of general terms which will recur again and again in the course of these studies. Various scholars have grouped the dynasties into several sections under denominations which, however, vary in their details.

Maspero, in his great History, expresses the arrangement thus (tome i., p. 229) :-

"Ancient history is divided into three periods, each of which corresponds to the suzerainty of a city or of a principality.

I. Memphite Period, usually called the Ancient Empire, from the Ist to the $\mathrm{Xth}$ dynasty : kings of Memphite origin ruled over the whole of Egypt during the major part of this epoch.

II. Theban Period, from the XIth to the XXth dynasty. It is subdivided into two parts by the invasion of the Shepherds (XVIth dynasty).

(a) The First Theban Empire (Middle Empire), from the XIth to the XIVth dynasty.

(b) The New Theban Empire, from the XVIIth to the XXth dynasty.

III. Saite Period : from the XXIst to the XXXth dynasty, subdivided into two unequal parts by the Persian Conquest.

(a) First Saite Period, from the XXIst to the XXVIth dynasty :

(b) Second Saite Period, from the XXVIIth to the XXXth dynasty." 
Griffith, in the eleventh edition of the Encyclopedia Britannica (I9I I), uses the following division :-

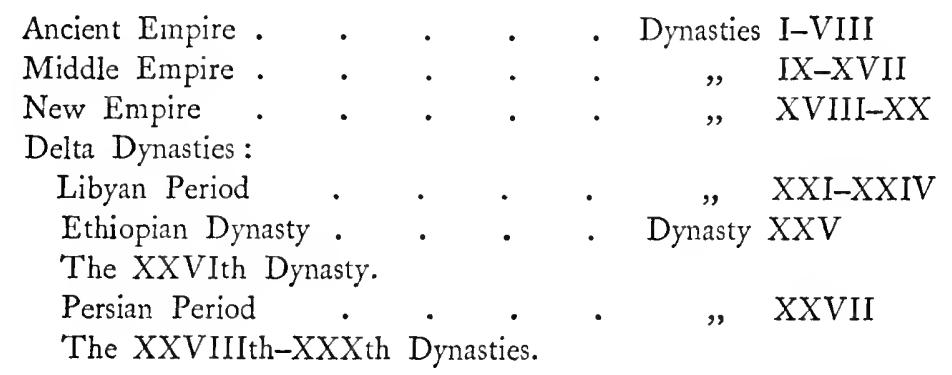

Finally, Steindorff, in the edition of Baedeker of I9I4, divides the dynasties as follows :-

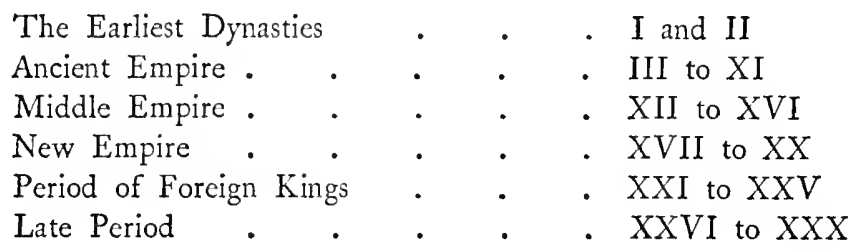

In point of fact these different classifications agree on the principal periods : Ancient, Middle and New Empire, and Saite Period; for the differences merely affect the intermediate periods. This is exactly what results from the uncertainty of our information as to these marginal epochs.

From all this we perceive that there are two obscure epochs, one between the Ancient and Middle Empires, the other between the Middle and the New, and a confused period between the close of the New Empire and the XXVIth dynasty. We find that the first two of these obscure periods have been times of artistic decadence in Upper Egypt. With the inauguration of the Middle Empire (XIIth dynasty), of the New Empire (XVIIIth dynasty), and again under the Saite Empire XXVIth dynasty), the artistic traditions of the great epochs were successively revived. On each occasion, in fact, the models which served in the most brilliant periods of the Ancient Empire were reverted to, so that Egyptian art may thus be described not as a gradual artistic evolution which perfected itself as the ages rolled 
on, finally to deteriorate and die out, but rather as a series of deviations, or of decadence followed by renaissance. It is thus that we can explain the fundamental uniformity of Egyptian art, in a number of its manifestations, in spite of the great diversity which we notice.

Let us try to form a general idea of the monuments which have come down to us, and which are to serve as the basis of our studies.

What has been said above on the subject of history in general cannot but be repeated in the case of the history of art. All our knowledge is above all things fortuitous; for certain periods materials abound, whilst for others, on the contrary, there are none at all, although one cannot legitimately infer from this lack of evidence that the Egyptians had completely ceased, for long ages, to produce works of art.

Certain classes of objects have entirely vanished. It is sufficient to cite but one example: the decorative goldsmith's work which is known to us through the representations of it on bas-reliefs and on paintings in the tombs and temples of the New Empire, where we see the kings presenting it as an offering to the gods, or the envoys of tributary states coming forward to lay it before the throne of the Pharaoh.

Of another kind of monument, which is mentioned at times in the texts, it chances that a single specimen has survived. This is the great statue in metal of King Pepi I of the VIth dynasty.

The division of the country into Upper and Lower Egypt is an important one from the point of view of the preservation of works of art. One might say, almost without exaggeration, that in the Delta everything has disappeared, whilst in Upper Egypt, on the contrary, a great number of antiquities is preserved. This difference can be accounted for in various ways, of which we may cite a few instances.

In the Delta, on account of the great distance of the quarries, most of the buildings were necessarily constructed of wood or brick, stone being but sparingly used only in the principal parts, such as in façades or in doorways. The 
PLATE I

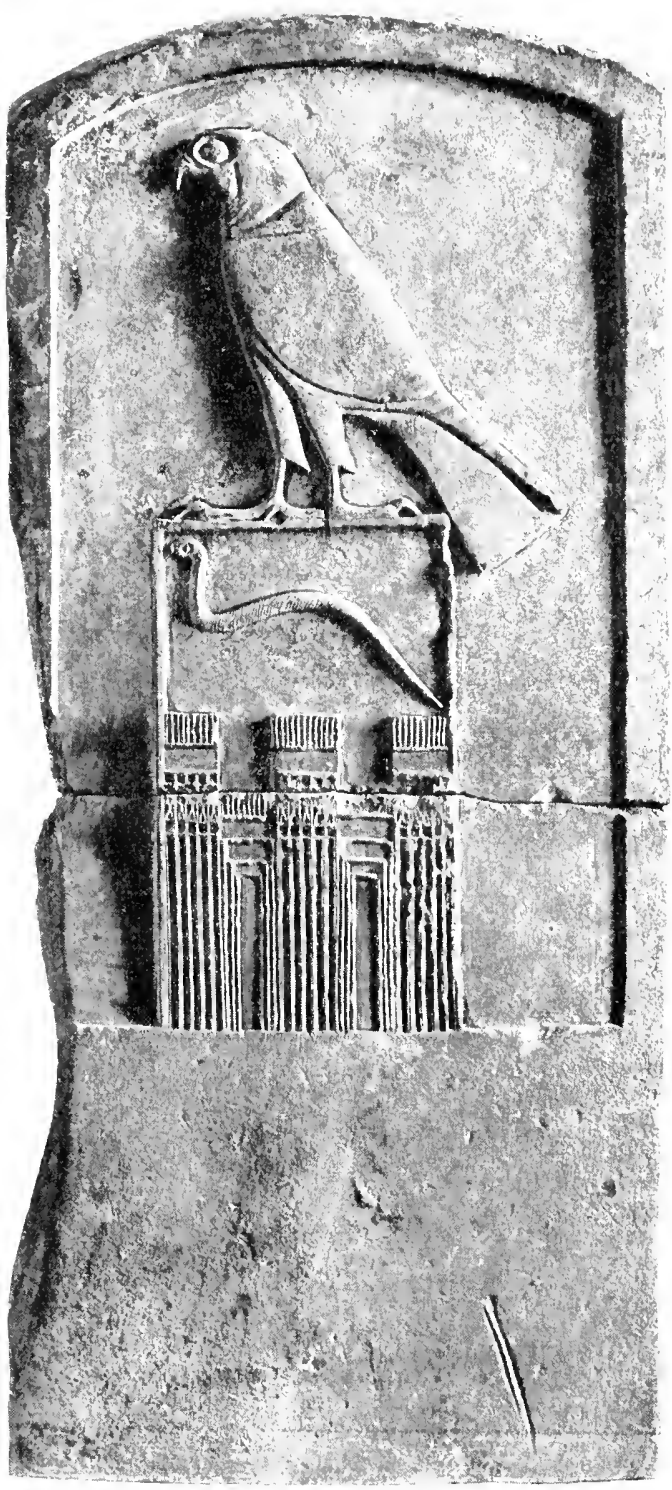



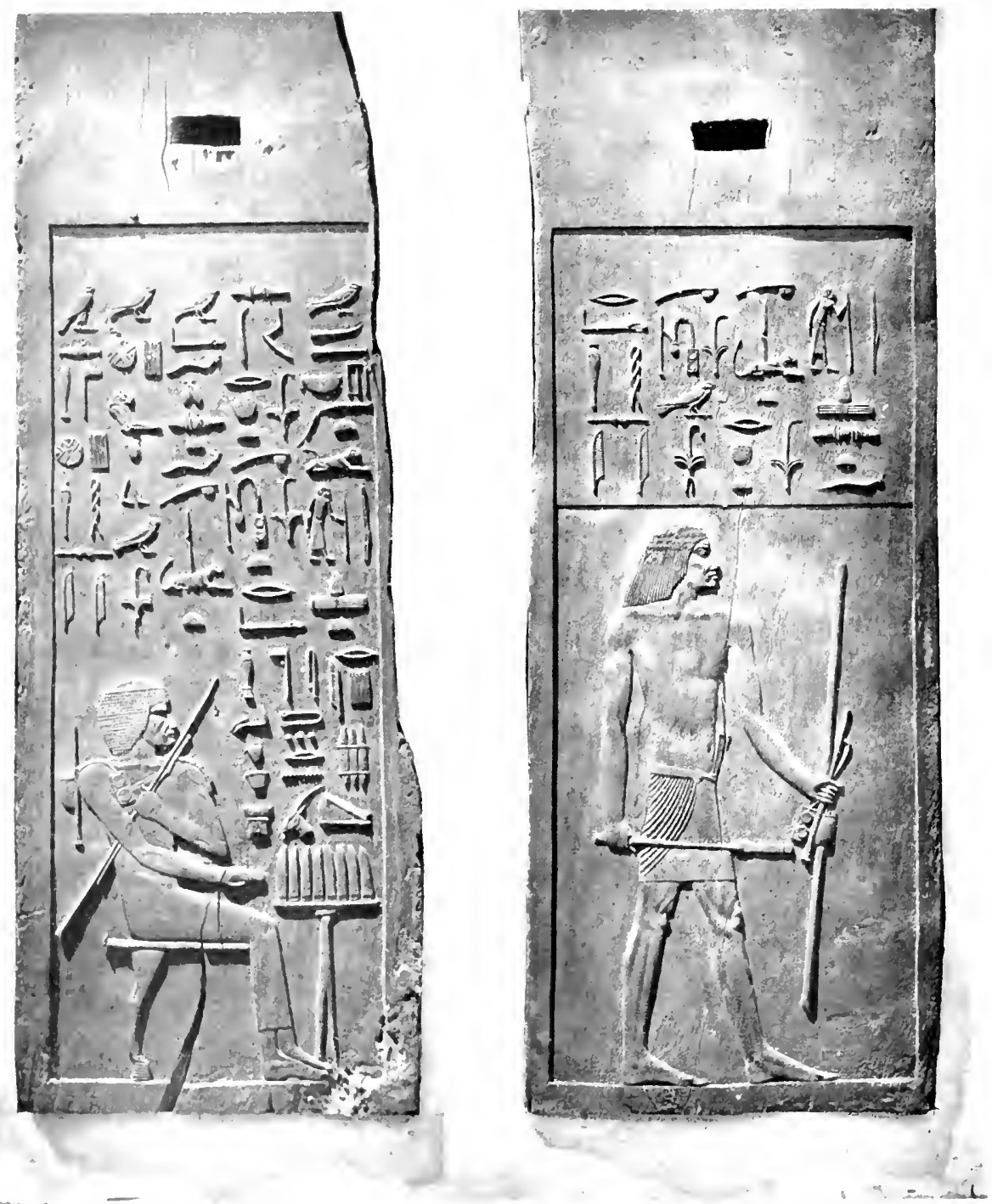


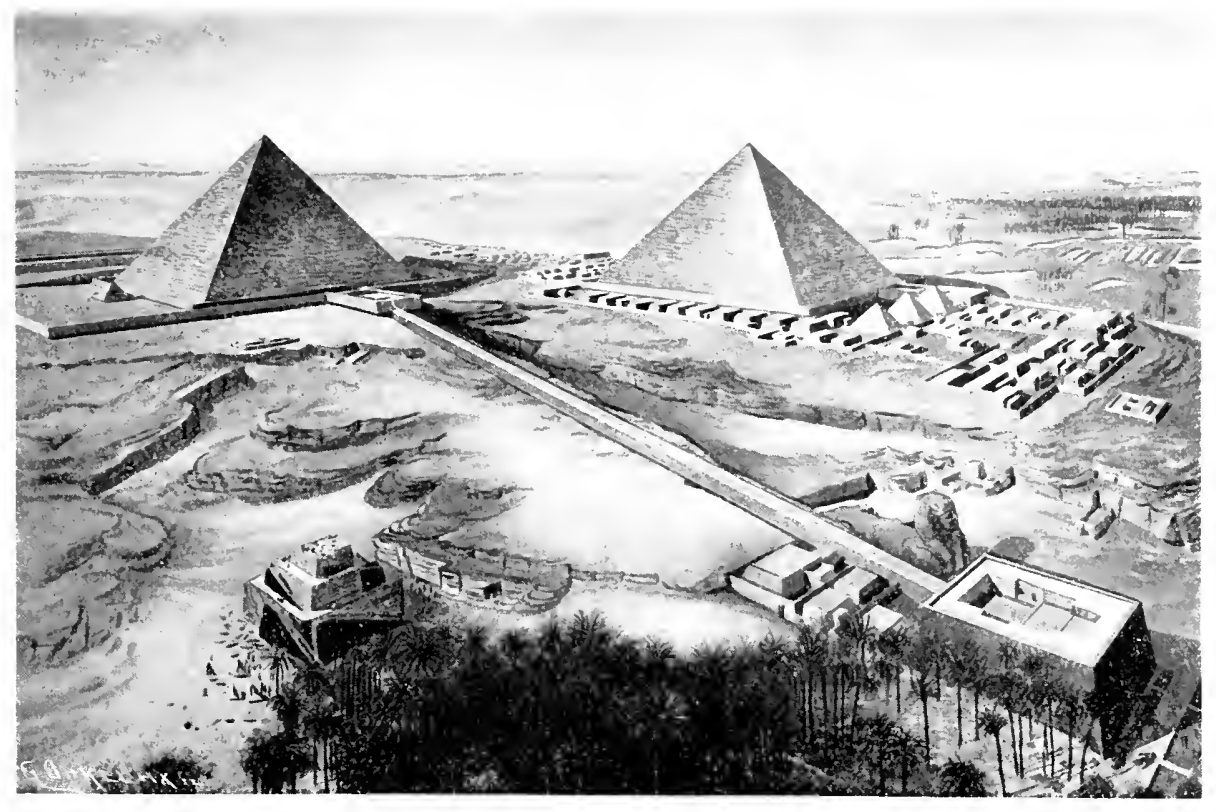



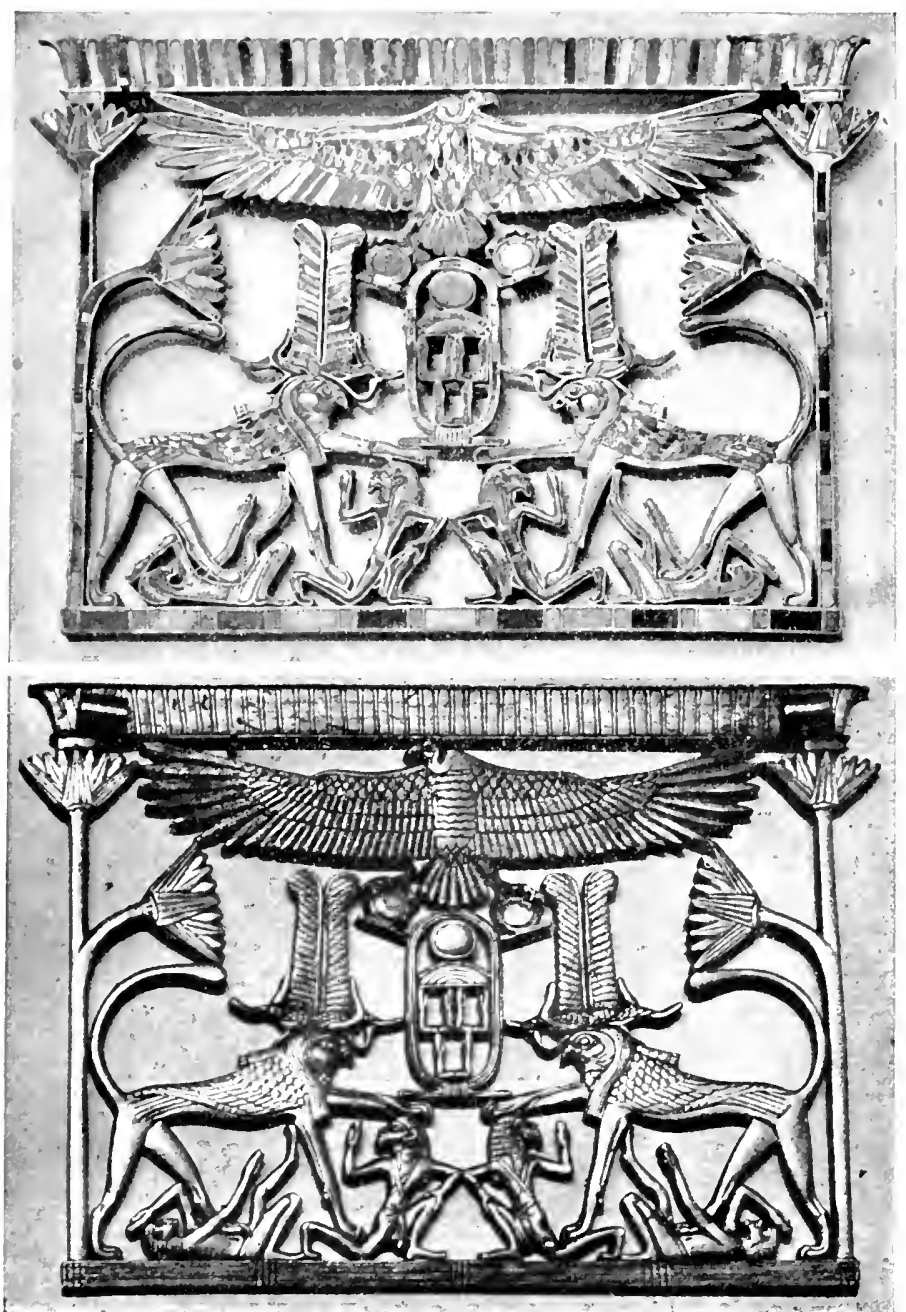
great growth of settlements and townships in Lower Egypt has led to a more and more systematic pillage of the ruins in order to carry off all the stones which can be re-used for building. The damp soil of the Delta has destroyed most of the objects confided to its care, whilst the desert of Upper Egypt has preserved them almost intact. But alike in Upper and Lower Egypt, other causes of destruction and disappearance are not lacking. Even in quite recent times antique sites have been exploited as quarries: the temple of Amenophis III at Elephantine, for instance, which was an object of great admiration to the savants of Napoleon's expedition, was completely demolished a few years later. Travellers in the first half of the nineteenth century have described (10) and published in their narratives of travel many once important ruins which have vanished completely to-day.

When one considers the countless wars and revolutions which have devastated the country (to say nothing of the fact that under the last dynasties Egypt submitted to at least two Ethiopian invasions, two Assyrian, and two Persian), and when one recalls the systematic destruction by the Christians who smashed the idols and the temples of false gods, and by the Arabs who mutilated all human figures, to say nothing of the ravages caused by excavators of long ago, one is astounded to find that so many Egyptian monuments still remain. And as though destruction by man were not sufficient, animals have done their share; one may instance the veritable invasions of white ants which have ravaged the ancient cemeteries.

It will now perhaps be convenient to draw up a kind of synopsis of typical groups of monuments which must occupy our attention, picking out characteristic examples from each kind and for different periods.

A monument of the Ist dynasty in the name of King Narmer (which some would identify with Menes, the first king to unite the two Egypts under one sceptre) is known as the Palette of Narmer. (II) It displays, amongst other things, a figure of the king clubbing a vanquished foe with his mace. From this monument onwards the general 
association of ideas is fixed, and the same theme reappears again and again across the whole page of Egyptian history. The same palette, by its portrayal of a ritual festival, makes it possible for us to trace, from the very beginning, the complex of motives which originate in the art of this remote epoch. The stele of the Serpent King, (12) now in the Louvre, is a masterpiece of execution. The falcon which surmounts the royal name is rendered with incomparable precision. One wonders for how long and with what thoroughness it must have been studied from nature before it became possible to seize with such perfection the characteristic form of the bird and to render the lines so simply and with so sure a hand that all the succeeding ages should find no need to alter in the smallest degree the outlines which thus became fixed and unchanging.

If we now glance at the reliefs on the wooden panels of Hesi, in the Cairo Museum, (I 3) which date from the first part of the IIIrd dynasty, we shall find there, perfectly employed, the fundamental conventions in Egyptian drawing of the human figure. Thus we see that the monuments of the first dynasties, rare as they are, display a fully developed art the execution of which is striking in its perfection.

The great necropolis areas, which extend all over the plateau of the Libyan desert from Gizeh to Meidûm (near the entrance to the Fayûm oasis), have preserved an important series of architectural monuments : royal tombs, generally in the form of pyramids; funerary temples of the kings, adjoining the pyramids themselves; and the tombs of high officials of the type called by archæologists " mastabas."

To cite some instances : the reconstruction of the temple and pyramid of Khephren, in a work by Hölscher, (I 4) gives us a general view of the necropolis of Kheops and of Khephren. In the background the great masses of the pyramids tower above the burial chambers of the kings; on their eastern faces the funerary temples stand, connected by a long passage to a kind of vestibule in the valley, at the foot of the plateau. Numerous mastabas are grouped around the pyramids, or in the neighbourhood of the vestibules in the valley below.

The same general arrangement is met with around the 
pyramid-temples of Abusir, where we shall find all the fundamental principles of Egyptian architecture in all ages employed by the architects of the Vth dynasty, especially the floral columns which are the most typical elements of this architecture.

The mastabas, which are massive rectangular piles, appear too as architectural complexes containing in embryo all the fundamental parts of the sacred edifice of Egypt. The walls of the chambers within are covered with bas-reliefs and paintings; in niches or in recesses hidden in the masonry are found numerous statues which furnish material for the study of sculpture in the round. To name three examples : The first is a diorite mask in the Leipzig Museum, reproducing the features of Khephren. (I 5 ) Detached from the statue, this fragment perhaps gains somewhat in beauty and lifelike intensity, separated as it is from the purely Egyptian peculiarities of form which sometimes offend our eye. Next comes the striking copper statue of Pepi I, mentioned before; ( 16 ) it bears witness to a very advanced knowledge in the rendering of anatomical details. It is, in fact, a real masterpiece in metal work. The material of which it is made has permitted the sculptor to separate the arms and legs entirely from the trunk without having to make use of slots for fitting which we find in stone statues. The two statues of Rahotep and Nofrit, found at Meidûm, complete our examples of the perfection of Egyptian art under the Ancient Empire. (I 7 )

Later ages may perhaps have produced more elegant works, but they have never succeeded in surpassing the Ancient Empire in truth and in fidelity to nature. We have thus attaching to this epoch a sufficiently numerous and varied group of monuments to help us to form an idea of the growth of art.

All of a sudden everything seems to dwindle and disappear, and the few monuments of the intervening period between the Ancient and the New Empires are of such a kind as to provoke the belief that some irremediable catastrophe has occurred. The most casual glance at the Dendereh stele of the end of the Ancient Empire shows to 
what depths of ugliness and coarseness Egyptian art must have lapsed, at least in Upper Egypt. (18) Had we not precise information as to date, one might easily imagine that the Dendereh reliefs are centuries older than the admirable statues of the Ancient Empire. One can scarcely attribute this to the clumsiness of some inexperienced craftsman, of whom a poor man had requisitioned a funerary stele in some provincial town. The royal monuments of the XIth dynasty give a scarcely better impression, for we find the fragments of a certain King Mentuhotep at Gebelein, reproducing the theme of the Narmer palette, which is treated in a stiff and angular fashion without any life. (19)

But a very short time had to pass before the kings of the XIIth dynasty had completely revived the traditions of the Ancient Empire. The bas-reliefs of Sesostris I at Koptos, as well as at Karnak, show us once more in their conception and execution the perfection of the work of the Ancient Empire.

We know of few great architectural monuments of the Middle Empire. Plenty of temples had fallen into ruin in the course of ages, had been restored (which generally means rebuilt) or enlarged by the sovereigns of the New Empire. A study, however, of the great funerary temple of the XIth dynasty at Deir-el-Bahari, whose ruins give us the data necessary for such a reconstruction, will serve to give a good idea of the abilities of their architects.

A careful study should be made of a number of interesting documents of the Middle Empire : the tombs of the nomarchs or provincial governors in Upper Egypt, the most remarkable of which are at Beni Hasan. The façade of the tomb of Chnumhotep II is justly celebrated for its so-called proto-Doric columns, and displays a standard of beauty and simplicity which only the architects of Greece, who came centuries later, were able to surpass. The walls of these same tombs present a most interesting series of reliefs and paintings.

Two lucky " finds" of caskets containing royal jewellery at Dahshûr and at Illahun make a welcome contribution to the study of the industrial arts. 
The New Empire will testify to a fresh revival of all the ancient traditions, when architecture will flourish on a majestic scale in the temples of the gods and of the funerary cult Thebes and Abydos, to name but the two most important sites, will furnish us with ample material for study. It will suffice here to cite one or two instances : the colonnade, in classic style, of the great temple of Queen Hatshepsut at Deir-el-Bahari is certainly one of the most amazing works which Egyptian architecture has bequeathed to us. Only the Cavetto cornice which surmounts the entablature informs us that we are not in the presence of a creation of the classic architects; but the bas-reliefs and the inscriptions stand there as an irrefutable proof against any classic influence, and show that the builders of Deir-el-Bahari lived a thousand years before the childhood of Greek architecture.

Luxor is a well-known name in the history of art : it is there that stand the gigantic piles to which the greatest kings of the XVIIIth and XIXth dynasties devoted their building activities. But it is at Karnak that the taste for the colossal manifests itself in all its fullness. The hypostyle hall, so vast that it could contain the whole of the structure of the cathedral of Notre Dame at Paris, has its roof upheld by I 34 columns, of which the highest are as massive as the Vendôme Column.

The famous temple at Abu-Simbel, which is entirely excavated out of the living rock, with its colossal statues fifty feet high, is a worthy architectural fellow to the temple of Karnak.

In the XXth dynasty the imposing mass of Medinet Habu, raised to the glory of Ramesses III, bears eloquent testimony that the greatest traditions were still flourishing at that time.

The hosts of New Empire tombs at Thebes and Tell-elAmarna furnish us with types of quite a long series of architectural styles. In some cases the sand has so acted as a preservative that we can find the structures almost in the state in which the Egyptians left them : such, for example, is the case of the central bay of the tomb of Ay at Tell-elAmarna. (20) 
The temples, as well as the tombs, have handed down to us countless statues, both of royal and of private persons, of all sizes, from huge colossi down to delicate little statuettes, and in every kind of material, displaying a surprising variety of different attitudes and forms.

It will suffice for the moment to instance one of the masterpieces of sculpture of the XVIIIth dynasty: the Karnak statue of Tuthmosis III, (2I) or the statue of Ramesses II, presenting a table of offerings, (22) which is at once one of the most lifelike and free productions of Egyptian art.

The court of Ramesses II at Luxor, with its great statues set up under the porticoes, proves that in spite of technical difficulties the kings did not shrink from the employment of colossi on a large scale.

As a specimen of a private statue, I will mention a handsome group in the Cairo Museum, portraying two persons a man and a women : Zai and Nai of the XIXth dynasty. (23) It is a graceful and fine piece of work, and is the type specimen of a whole class of sculptures.

In the midst of the New Empire, at the end of the XVIIIth dynasty, we must assign a special place to the monuments which are associated with the name of Amenophis IV. This strange Pharaoh, the religious and political reformer, has set his mark upon all the artistic productions of his time. The merest glance at the most exquisite piece of the series, the head of the queen in Berlin Museum, (24) reveals to the beholder an aspect of Egyptian art widely different from all else connected with the ordinary acceptance of the term.

As may well be imagined, the walls of the temples and tombs of the New Empire have provided an incredible number of bas-reliefs, paintings and drawings. We may cite a single sketch in the tomb of Ramose at Thebes, where the artist has depicted in a group the characteristic features of the races bordering upon Egypt with a precision which the most critical eye would find it difficult to find fault with. (25)

The wealth of Egypt at this time did not fail to give 


\section{THE FRAMEWORK OF HISTORY}

a great stimulus to the industrial arts : thus the tombs have preserved for us a number of pieces of the highest order, especially furniture. Fancy articles are known, as regards the New Empire, in richer abundance than at any other period. Can one imagine any object more truly artistic in its composition than the unguent-holder in the Liverpool Museum, which is made in the form of a statuette of a slave, bearing upon his shoulder a large vase? (26) The same motif is used, with suitable modifications, in one of the most beautiful wooden unguent-spoons in the Louvre. (27)

After this spell of great abundance in the New Empire, we find ourselves almost entirely unprovided with documents for the next few centuries. The XXIst to the XXIVth dynasties have left little by way of architecture; but as to sculpture the discovery of a hoard at Karnak has supplied us with an extensive series of statues of the chief members of the priestly families. These works are interesting certainly, but they display no particular characteristics.

We may mention several statues of the Ethiopian XXVth dynasty, as, for instance, those of Mentuemhat, who was governor of Thebes at the time of the Assyrian invasion. (28)

Of the Saite Empire (XXVIth and following dynasties) scarcely anything has survived. Certain statues and reliefs, however, are sufficient to testify to a renaissance, and that once more the Egyptians are drawing their inspiration from the most ancient models. In architecture, one building, the Kiosk of Nectanebo in the island of Philæ, is the introduction to the long series of Græco-Roman monuments. The Ptolemies, and then the Emperors, did, in fact, raise important buildings in different parts of Egypt, which are quite enough to show how much vitality the ancient art of the Pharaohs still possessed in their day, and in this connection it is sufficient to cite the well-known names of Philæ, Edfu and Dendereh. There we shall find buildings almost intact in some parts, and the study of these makes it possible for us to restore, at least in spirit, the great ruins of the preceding ages. When one paces the pathway around the 
temple of Edfu, or wanders among the columns of the hypostyle hall at Dendereh, one might easily be tempted to imagine that time had stopped for hundreds of years, and that one would see, without much surprise, the Egyptian priests, with their white robes and close-shaven heads, sally forth from one or other of the chambers.

The bas-reliefs, of almost infinite extent, show us the Greek dynasts or the Roman Emperors doing their best to look like the native Pharaohs, their far-off predecessors. The execution has unfortunately fallen short of its intentions, and sculpture in relief, as opposed to architecture, betrays the imminent decline into which Egyptian art was soon to lapse.

Such is the general outline of the groups of Egyptian documents which must serve as the basis of art-study; but up to the present we have as yet not spoken of dates, and it is now time that we should devote a few words to the complex question of Egyptian chronology.

Years were reckoned according to the reigns of the kings, and to restore actual dates we should have, theoretically, a complete catalogue of sovereigns and the highest years of each of their reigns. Such, however, is far from being the case.

One resource at our disposal is to consult the synchronisms of Egyptian history with those of neighbouring peoples : Greeks, Persians, Babylonians and Assyrians; another resource is furnished by the Bible. It is thus that we can affirm that Psammetik I, of the XXVIth dynasty, ascended the throne towards 663 ; that Seshork I (Sishak), of the XXIInd dynasty, pillaged the temple of Jerusalem in the reign of Rehoboam in 928 ; that Amenophis IV, of the XVIIIth dynasty, was a contemporary of King Burnaburiash II of Babylon, who reigned about I 400 .

Sometimes the Egyptian texts furnish astronomical dates calculated by the rising of Sirius (Sothis). These astronomical dates are founded on the following facts : In theory the first day of the first month of the Inundation-that is to say, the beginning of the inundation, which at Memphis took place on July 19 th-coincided with the rising of Sirius. 


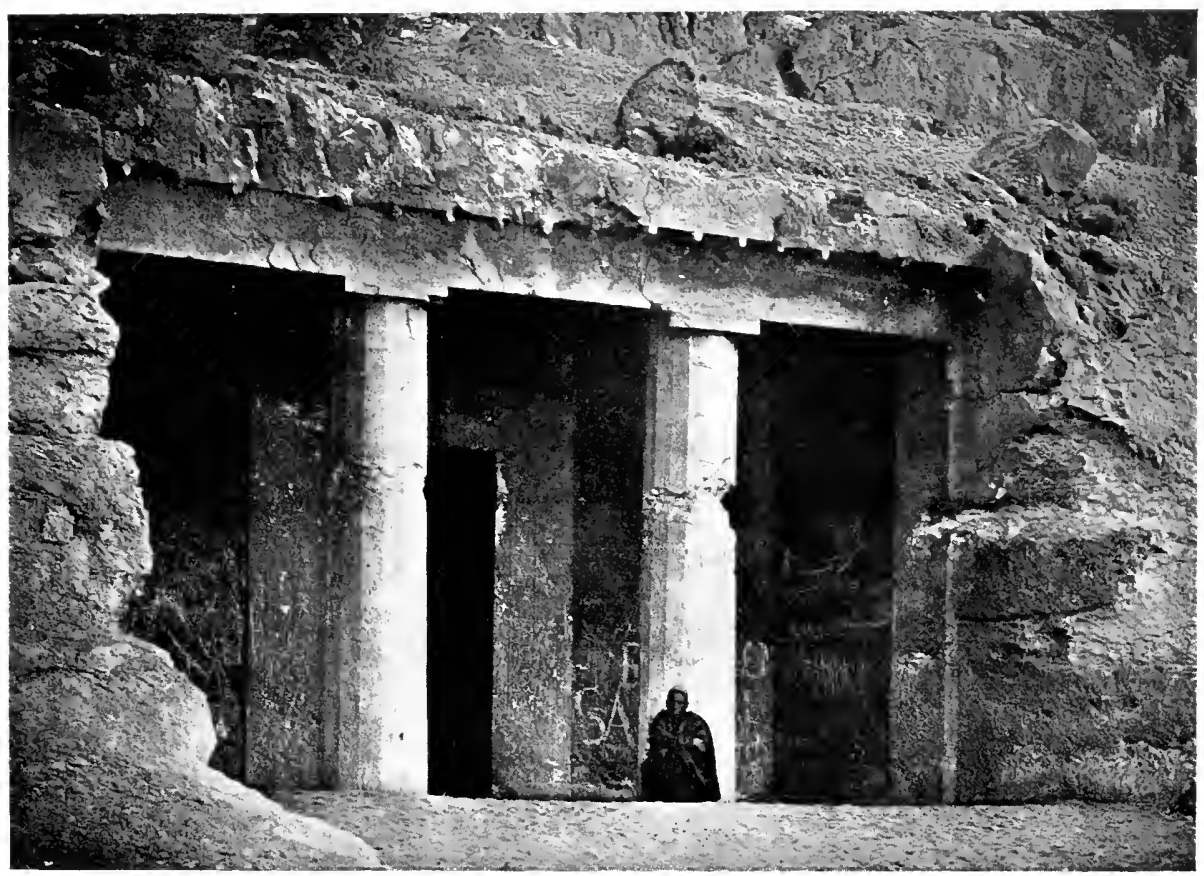




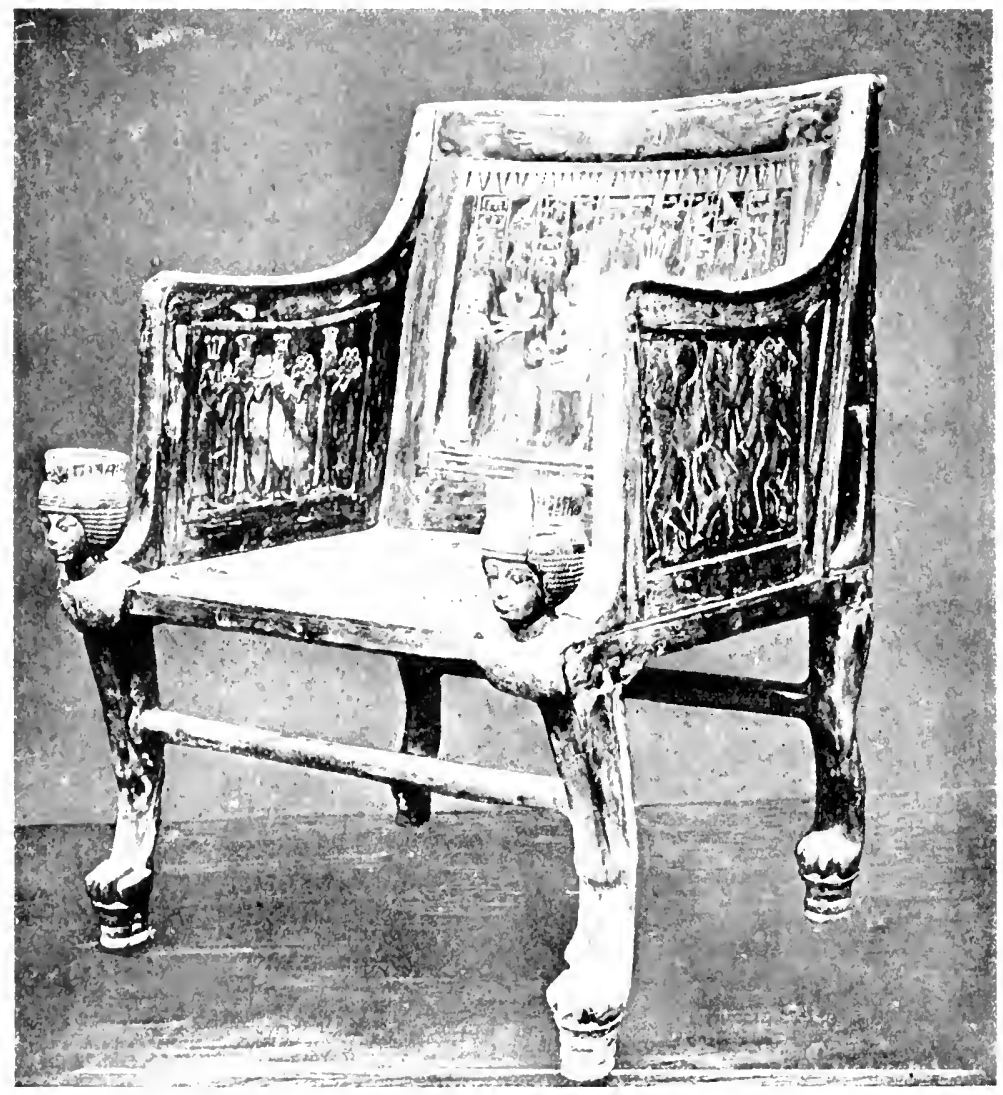


But the ordinary Egyptian year, which consisted of twelve months of thirty days each, plus five supplementary days (called the Epagomenal Days), proved to be shorter, by a quarter of a day, than the astronomical year. There was thus a difference of one day in every four years, and the rising of Sirius fell one day earlier than the four years before. There was therefore a wait of $\mathrm{I}, 460$ years before the coincidence recurred. In other words, $I, 460$ astronomical years were equal to $\mathrm{I}, 46 \mathrm{I}$ civil years.

Ptolemy II Euergetes, by the Decree of Canopus, ordered the introduction of a supplementary day every four years; but this reform was not followed till the time of Augustus, who introduced the Julian year.

When a king of Egypt said, in an inscription, that on such a day of such a month the rising of Sirius was celebrated, it is possible to calculate by the difference between this date and the beginning of the year the exact point in the astronomical cycle at which the inscription was drawn up. By such means a deduction has been made, from a date in the Ebers papyrus, as to the ninth year of the XVIIIth dynasty King Amenophis I, which would have fallen between I 550 and I 546 B.c. An inscription from Elephantine proves that a year, not determined, of Tuthmosis III of the XVIIIth dynasty, fell between 1474 and 1470 . In the same way it seems to follow from an indication in a papyrus from Kahun that the seventh year of Sesostris III of the XIIth dynasty must have fallen between 1882 and 1878 B.c.

But here we stumble upon a difficulty which would seem insurmountable in the present state of our knowledge: there is an irreconcilable lack of harmony between the astronomical dates of the XVIIIth and XIIth dynasties, on the one hand, and the royal monuments which should be placed between these two dates on the other hand. Thus, if the XIIth dynasty ended towards I 790 and the XVIIIth began about 1570 B.c., the space between the two would be only 220 years. Now we already know of more than a hundred kings, mentioned on the monuments or papyri, while new names have again recently emerged, and, according 
to the fragments of the Turin papyrus, one is forced to conclude that there reigned, within this space of time, from I 60 to 200 kings. (29)

It has been proposed, in order to solve this difficulty, to add another Sothic period, and to add, accordingly, I, 460 years to the date I790, which would place the end of the XIIth dynasty at 3,250 B.C. This system moves the Midde Empire back to the region of the date which was generally accepted, until, in consequence of the discovery of the Kahun papyri, some scholars contrived to shorten Ancient Egyptian chronology excessively.

The following short table gives the dates proposed for various dynasties by Meyer in I 904-8; Sethe in 1905; Breasted in 1906 ; Petrie in 1906; and Borchardt in I917. (30) In the last column are placed the approximate dates which will serve for all practical purposes in these studies.

\begin{tabular}{|c|c|c|c|c|c|c|}
\hline Dynasty. & Meyer. & Sethe & Breasted. & Petrie. ${ }^{1}$ & Borchardt. & \\
\hline I & 3315 & 3360 & 3400 & 5510 & 4186 & About 5000 \\
\hline IV & 2840 & 2720 & 2900 & $473^{I}$ & 3430 & $\begin{array}{l}\text { About } 4000 \text { Ancient Em- } \\
\text { pire }\end{array}$ \\
\hline XII & 2000 & 2000 & 2000 & 3459 & $\begin{array}{r}1996 / 5 \\
-1993 / 2\end{array}$ & $\begin{array}{l}\text { About } 3000 \text { Middle Em- } \\
\text { pire }\end{array}$ \\
\hline XVIII & 1580 & - & I 580 & 1580 & - & About I 500 New Empire \\
\hline XIX & I32I & - & I $35^{\circ}$ & 1322 & 一 & \\
\hline XXII & - & - & - & - & - & About 1000 \\
\hline XXVI & - & - & 一 & 一 & 一 & VIIth century \\
\hline \multicolumn{3}{|c|}{ Conquest of Alexander } & 一 & - & 一 & 332 \\
\hline
\end{tabular}

\section{BIBLIOGRAPHY.}

I. Sethe, K., in Borchardt, L., Das Grabdenkmal des Königs Sa'hure', t. ii., die Wandbilder (Wissenschaftliche Veröfentlichung der deutschen OrientGesellschaft 26), Text, p. I4. Leipzig, I9I3.

2. Schäfer, H., Ein Bruchstuick altägyptischer Annalen, in the Abhandlungen der preussiche Akademie der Wissenchaften, 1902, Anhang. Berlin, 1902.

Gauthier, H., Quatre nouveaux fragments de la Pierre de Palerme, in Le Musée égyptien, t. iii., 2, Le Caire, I9 I5, pp. 29-53, pl. 24-31.

I Petrie in I9I I fixed the reign of Menes, the first king of the Ist dynasty, at 5546 . 
3. Meyer, E., Chronologie egyptienne, traduit par A. Moret, in the Annales du Musele Guimet, Bibliothèque d'Etudes, t. xxiv., 2, pp. I $47 \mathrm{ff}$.

4. Ibid., Pp. I 43 ff.

5. Ibid., pp. $100 \mathrm{fr}$.

6. See for example E. de Rougé, Recherches sur les monuments qu'on peut attribuer aux six premières dynasties de Manthon, in the Mémoires de l'Academie des Incriptions et Belles-Lettres, t. xxv., 2, I 866 ; reprinted in E. de Rougé, Euvres diverses, t. vi. (Bibliothèque égyptologique, t. rxvi.), Pp. 5-I57 with 8 plates.

7. Griffith, Encyclopadio Britannica, I Ith edition, s.v. Egypt, p. 4 I b.

8. Wiedemann, A., Aegyptische Geschichte. Gotha, I884; Supplement. 1888 .

Petrie, W. M. F., A History of Egypt. London, Methuen, various editions.

9. Maspero, G., The Dawn of Civilisation, The Struggle of the Nations, The Passing of the Empires, various editions.

Meyer, E., Geschichte des Altertums, 3rd edition, r9r3.

Breasted, J. H., A History of Egypt from the Earliest Times to the Persian Conquest. London and New York, I905; 2nd edition, I9I9. A History of the Ancient Egyptians. London, I9I8.

10. Newberry, P. E., The Temple of Erment as it woas in 1850 , in the Proceedings of the Society of Biblical Archceology, t. 27, 1905, p. 100 and plate,

I 1. Capart, J., Primitive Art in Egypt, figs. I 83 and I 84.

12. Bénédite, G., La Stèle dite du roi Serpent, in the Monuments Piot, t. xii., I 905 , pl. I.

13. Quibell, J. E., The Tomb of Hesy (Excavations at Saggara, I9II-I2). Cairo, I9I3.

14. Hölscher, U., Das Grabdenkmal des Königs Chephren. Leipzig, I9r2, pl. I.

15. Borchardt, L., in Hölscher, U., Das Grabdenkmal des Königs Chephren, Leipzig, I912, pl. XVI.

16. Quibell, J. E., and Green, F. W., Hierakonpolis II. London, 1902, pls. L-LII.

17. Mariette, A., Voyage dans la Haute Egypte, Cairo, I878, t. i., pl. XVI.

I 8. Petrie, W. M. F., Dendereh, London, I 900, pl. XI, the stelæ of Nekhtu and of Hennu, now in the Ashmolean Museum, Oxford. pl. $33 a$.

I9. Bissing, Fr. W., Denkmöler ägyptischer Sculptur. Munich, I906,

20. Davies, N. de G., The Rock Tombs of El Amarna, Part VI. London, I 908 , pl. XXXVII.

21. Legrain, G., Statues et statuettes de rois et de particuliers, t. i., Cairo, I906, pl. XXIX-XXX.

22. Legrain, G., ibid., t. ii., Cairo, rgog, pl. IV.

23. Maspero, G., Le Musée égyptien, t. ii., I. Le Caire, I904, pl. VI.

24. Fechheimer, H., Die Plastik der Aegypter. Berlin, 1920, pl. 79-80.

25. Prisse d'Avennes, Histoire de l'Art Egyptien. Paris, 1878, t. ii., pl. IV.

26. Capart, J., Figurine egyptienne en bois au Musie de Liverpool, in the Reoue archéologique, 1907, t. ii., pl. 371 .

27. 'Maspero, G., Essais sur l'Art Egyptien, Paris, Ig I 2, fig. 82, p. 245. 


\section{4}

\section{EGYPTIAN ART}

28. Legrain, G., Statues et statuettes de rois et de particutiers, t. iii. Cairo, I 914 , Nos. 42236 to 4224 I and pl. XLIV-XLVIII; Wreszinski, W., Eine Statue des Monthemhet, in the Orientalistische Literaturzeitung, t. I9, I916, col. IO-I 8, with 3 plates.

29. Griffith, F. Ll., Encyclopeedia Britannica, s. v. Egypt, p. 79.

30. Borchardt, L., Die Annalen und die zeitliche Festlegung des alten Reiches der ägyptischen Geschichte. Berlin, I9I7. 


\section{CHAPTER III}

\section{PRIMITIVE UPPER EGYPT}

$7 \mathrm{HE}$ previous chapter has given us a glimpse of some of the highest points reached by Egyptian art in he course of its history, and we must now survey the most humble and most rudimentary efforts handed down to us through the burials of archaic times. (I)

About twenty-five years ago Petrie found the first tombs of a special type which was a puzzle to archæologists. These tombs took the form of a more or less regular trench dug in the desert in which the body was laid in a position different from anything previously known to Egyptian funereal archæology. Beside the corpse were arrayed an abundance of objects which conformed to no known type. There was some hesitation in assigning these burials to any definite period of Egyptian history until it was recognised, when further documents came to light, that they could be designated as the very earliest tombs of the inhabitants of the Nile Valley.

Let us now examine a few types. In one, the body, in a contracted attitude, with the knees drawn up to the chest and the hands bent over the face, was wrapped in matting and laid in a cavity more or less oval in shape. (2) In another, the trench is rectangular, the body is lying in the usual manner on its left side in the attitude just described, and all around it are vases of various types intended to contain funereal food. (3) Sometimes the body, the flesh having previously been removed, is placed in a coffin of burnt clay, in which likewise are found the various objects which made up the funerary gear. (4) The pottery coffin, or chest, sometimes fills only a part of the trench; in such cases 
the gear is arranged partly within the chest and partly outside it. (5) The trench, which in other cases reaches considerable size, is divided into a number of compartments, the greatest being the funereal chamber proper, the others forming a kind of repository for the burial objects and for offerings. (6)

The determination of the epoch to which these tombs are assignable being generally admitted, it remained to attempt a classification of them in chronological succession. Professor Petrie, in his memoir on Diospolis, was able, thanks to the abundance of the material he found and to the minute care with which excavation was conducted, to draw up a chronological basis for these primitive tombs.

$\mathrm{He}$ distinguished a certain number of trenches, marked by the numbers 30 to 80 , which he called " Sequence Dates." (The numbers below 30 were reserved for the discovery of burials still more ancient.)

The general development of the civilisation revealed by this study showed that two periods could be distinguished. This resulted mainly from the analysis of the pottery, which was, as we have seen, particularly abundant, and provided a whole series of distinct varieties. The first period is characterised by pottery with a red ground, whilst the second is chiefly marked by pottery with a light ground.

Red Ground.-The colouring is obtained by a coating of hæmatite, which gives in the baking a fairly vivid red. A distinction must be made between the vases called "blacktopped "(that is to say, those whose upper parts are black) and "red-polished" (vases with a polished red surface). The black colouring of the edges is produced by the reduction of hæmatite under the influence of oxide of carbon, released by the partial combustion of wood in the course of the baking. Petrie has named the red vases decorated with markings of white " cross-lined," and these are characterised mainly by designs in intersecting white lines.

Light Ground.-In this second category are included the vases called "wavy-handled," " decorated," "late" and "rough-faced." The first mentioned derive their name from the attachment fixed by the potter to the body of the vase about its widest part in the form of a wavy strip of 
clay, with the object of holding the cordwork from which the vessel was suspended. The vases of this order have different shapes, passing from a globular type with a wide body to a perfectly cylindrical type. The more the vase approximates the cylinder, the more the wavy handle tends to encircle the body completely, until in the totally cylindrical type the zigzag line completely encircles it.

The "decorated" pots bear on their surfaces paintings in red or brown colours, of which some imitate basket-work, whilst others represent different subjects to which we shall come later on.

The "late" vases show an even surface, whilst the "rough-faced" have, as the name implies, a rugged ground and are made of coarser material.

Petrie drew up a fundamental series of vases of the most frequent types at different periods of the primitive epoch. This classification is based upon the appearance, development, and disappearance of various types, as well as upon the relative number of different types in one and the same tomb. If one reduces a characteristic plate in Petrie's Diospolis (Plate II) to the form of a chart, the following result is obtained :-

\begin{tabular}{|c|c|c|c|c|c|c|c|}
\hline Typc. & 30. & $31-4$ & $35-42$. & $43-50$. & $51-62$ & $63-7 \mathrm{r}$ & $72-80$. \\
\hline irst C & & & & & & & \\
\hline $\begin{array}{l}\text { Blacl } \\
\text { Red }\end{array}$ & 5 & 3 & $\begin{array}{l}3 \\
4\end{array}$ & $2^{2}$ & 二 & 二 & z \\
\hline Cross-lined. & - & 2 & 4 & 二 & $\overline{-}$ & 二 & $=$ \\
\hline econd Group Light- & & & & & & & \\
\hline W & - & - & $\mathrm{I}$ & I & I & 2 & 2 \\
\hline ted & 二 & 二 & 二 & 4 & $\begin{array}{l}3 \\
3\end{array}$ & $\begin{array}{l}\mathrm{r} \\
6\end{array}$ & $\overline{4}$ \\
\hline Rough & - & - & - & - & 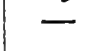 & - & I \\
\hline
\end{tabular}

At sequence date 30 the table shows five black-edged vases to one red-polished. At sequence date $3 \mathrm{I}-4$, for three black-edged vases there are three red-polished and two cross-lined. The black-topped are still represented 
by three specimens at sequence date $35-42$, by two at sequence date 43-50, after which they disappear. The wavy-handled series is arranged beginning with globular and ending with cylindrical vases. It will be observed that the wavy-handled vases are rather rarer with the blacktopped group, while they are more frequent with all the other categories of the second group, and furnish thus a dividing line between the two. Discoveries on sites of the earliest dynasties conform to this arrangement, showing as they do that the cylindrical vases (which are derived from the wavy-handled) persist into the historic period, whilst the black-bordered red pottery completely die out (subject to a reservation to which we shall refer later on). It can be shown that the point of contact of the Ist dynasty with the system of sequence dates falls somewhere in the neighbourhood of sequence date $75 \cdot(7)$

The results thus arrived at by Petrie have been confirmed by the various excavations carried out in recent years by different explorers. Never-when sufficient attention has been paid to minute details-has the general framework established by the English excavator been broken down by the excavations of the American Reisner at Naga-edDerr, or the Austrian Junker at Tourah, or the German Möller at Abusir-el-Meleq. Never has a tomb yielding an assortment of pottery controverted the table set out above.

It thus becomes certain that the tombs discovered in Upper Egypt belonging to the primitive period fall into two groups, distinguished principally by their pottery.

In recent years, consequent upon the operations of raising the Assuan barrage, the Egyptian Government decided to have explorations made over all the Nubian burial-grounds before they had to be submerged. The discoveries which resulted from these excavations have been most important from the point of view of augmenting our knowledge of the primitive period. (8)

In Nubia also two periods are recognisable, the first offering complete identity with the first period of Upper Egypt. On both sides the same civilisation is manifested by the objects from the tombs, nor is there evidence of any 


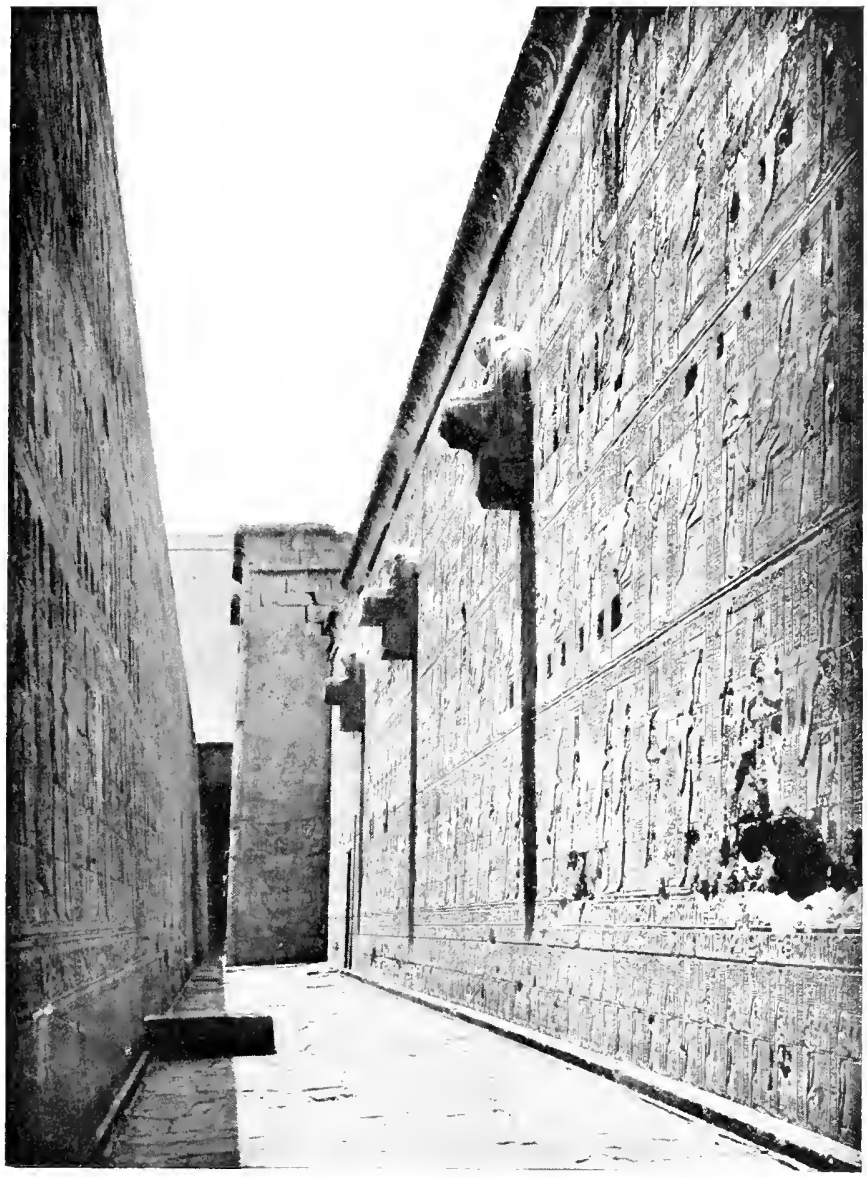

GARGOYLES IN THE WALL OF THE TEMPLE OF HORUS AT EDFU 


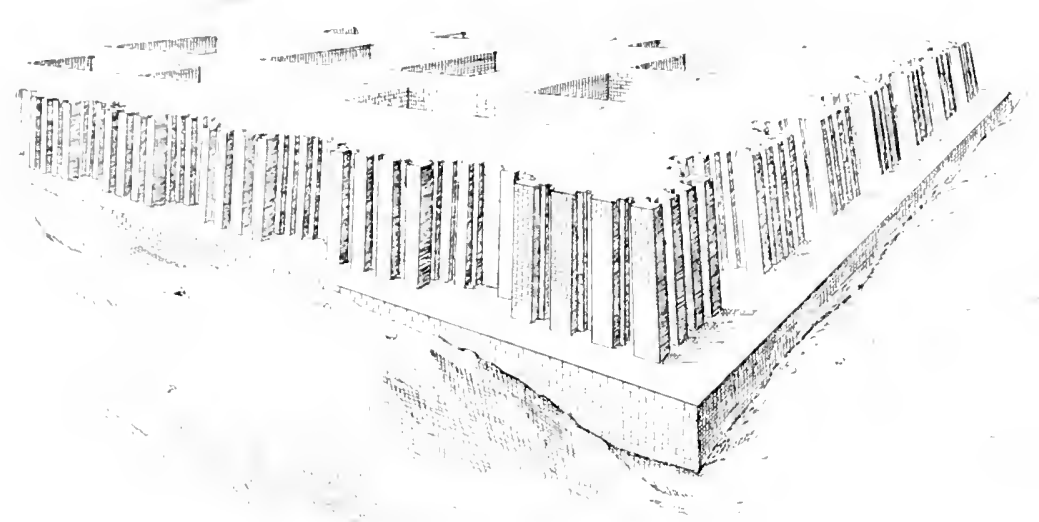

THE ROYAL TONB OF NIQADA AS RESTORJI)

BY DE MORGAN 
type which might be called distinctively Nubian. As regards the second period, it is noticeable that there is a persistence of primitive types which had disappeared in Egypt : the forms change, but the genres survive. The vases of the second Egyptian period, particularly the wavyhandled, as well as the decorated, appear but in small quantities in the Nubian tombs, as if the centre from which these varieties of pottery radiate were more remote in Nubia than in Upper Egypt. Under the Ancient Empire the Pharaonic civilisation of Egypt does not make itself apparent in any marked degree beyond the First Cataract; and naturally the burials continue to yield objects of a type quite of their own and derived from primitive models. If, then, there is disappearance in Upper Egypt, there is also survival in Nubia, and this survival accounts for sporadic reappearance of vases of Nubian type in Egypt which recall the productions of the primitive period. This explains how it is that Maspero found, at El-Khizam, black-topped red vases under a VIth dynasty stele : and it explains also the finding of Nubian pottery in the tombs called pan graves at Diospolis, etc.

Reisner's recent excavations at Kerma in the Sudan have likewise shown the existence of red pottery with black tops of wonderful perfection. Several specimens have been previously found in Egypt, at Abydos, Kurna, etc., but it has not been known to what centre of manufacture to relegate them. The Meroitic pottery of Ethiopian times shows the late survival of the pottery of the most ancient period of Upper Egypt.

Primitive civilisation ebbed from north to south, following the course of the Nile. The information gained from these remarks enables us to say that the second period in Upper Egypt shows the influence of contact with a neighbouring civilisation which we naturally look for in Lower Egypt.

But there is not only the pottery of the tombs to consider ; other objects must claim attention. We will mention first of all the hard stone vases which constitute one of the most surprising industries of the inhabitants of Upper Egypt. The material was everywhere ready to hand, but it 
would seem that, attracted by the difficulty of the task, they set themselves generally to carve the very rocks which offered the greatest resistance with an accuracy which is simply astounding. Without entering into a special study of this category of objects, two observations must, however, be made. Several of the most frequent types are copies of the pottery vases of the second period, globular pots with cylindrical handles, a form only really necessary in the case of mud-made vessels, for a cylindrical handle of stone is very difficult to work, and is, moreover, useless, for there is no fear that the suspending cord would cut through the granite by rubbing; in the earthenware, on the contrary, a wide cylindrical handle is the guarantee of long use of a vessel. The second observation to be made is that, from the time of the first dynasties, if stone vases continued to be made, the hardest rocks would be abandoned little by little in favour of softer materials, particularly alabaster. The Egyptians of the earliest dynasties possessed beautiful vases made of metal, the use of which supplanted that of stoneware, which was finally abandoned.

Much the same happened in the case of working in flint. The tombs of primitive times furnish admirable flint knives, worked with really astounding dexterity. Towards the close of the second period these beautiful flakes suddenly give place to much coarser productions, (9) some of which are palpable imitations of metal implements, as for instance knives with handles. (IO) The explanation is not far to seek : a new industry, coming from without, had lowered the value of the masterpieces made of a material which would henceforth serve only the needs of the lower orders of the population.

So far we have confined our attention to the products of the industrial arts, but the burials have also yielded objects which enable us to form an idea of the capacity of the primitive races in sculpture and draughtsmanship.

In several tombs the presence of modelled figures has been made known : these are rude attempts to render, in clay or bone, the human form, and may be compared, for instance, with two female figurines in the collections of the 
Brussels Museum. One is armless, the arms being reduced to mere stumps; the other has both arms, which end in bird's claws and are raised above the head in an attitude of dancing or of lamentation. The shape of the body is clumsily rendered : the feet are lacking and the head resembles that of a bird, perhaps in the attempt to portray a woman carrying her head high in the air with the chin thrust forward. We may mention too, from the same museum, two hippopotamus teeth : the upper part is carved to represent a bearded head. The work here is rather better, and one might even allow for it a certain dexterity in rendering the characteristics of the race. Sometimes animal figures are foundoxen, cows, sheep or hippopotami, wrought in different materials. Finally, boats fitted up with their equipment have been discovered, and even, in one case, a model of a house with clay walls. (I I)

All this is very rudimentary, but nevertheless extremely interesting in showing that the primitive inhabitants of Upper Egypt had funerary rites bearing great analogy with those of the Pharaonic Egyptians. The dead man desired to have in his tomb, ready at hand, not only funerary offerings, but model dwellings, boats, little models of cattle, and even of slaves, both male and female. It would be difficult to affirm summarily that there was simply an analogy derived from similar animistic conceptions. Would it not be better to consider the hypothesis of one civilisation borrowing from another?

We may also note, in passing, various objects of clothing or attire : these are the combs decorated on the upper border with figures of antelopes or birds, spoons with handles made up of little carved animals, such as a lion chasing a dog.

Drawing and painting are known to us chiefly from the decorated pottery mentioned above. The most frequent design is a fairly complex contrivance formed by a double line curved in the shape of a bowl, with numerous strokes on the lower part, two little constructions above and towards the middle, and two kinds of banners. Some would see in these designs representations of villages, but the majority of archæologists consider them to be boats. (12) The two 
incurved lines constitute the hull, the little strokes below are the oars, and the constructions within are the cabins. One plate published by Petrie (13) collects together the greater number of fundamental types. On the first line two rows of birds, flamingos or ostriches, alternate with two boats. Above the second are two antelopes. On the second line we find the birds and boats and a crocodile. The third line shows, both above and below the boats, a series of triangles, in which we recognise mountains. Further on we have a series of mountains, two large boats separated by a plant on each side of which are stationed two female figures whose attitude recalls the pottery figures we have just described. Looking a little more closely at the boats on his specimen, we notice in the fore part a rope and a mooring post. At the prow is a sort of palm-leaf, which serves as a shelter for the pilot; at the stern three great oars ending in paddles, recalling exactly the great steeringoars which are usual on the Egyptian boats in historic times. Behind one of the cabins, a standard surmounted by the figure of an elephant indicates, we must suppose, the locality from which the boat has come. The careful study of the different standards depicted on the pottery shows that it is possible to group them in a series in which are found several signs which were used in later times in the hieroglyphs to denote the provinces of Lower Egypt. (14)

The object of these paintings must be sought for in connection with their presence in the tombs, and it would seem that the scenes painted or drawn are used to replace models and figures. By this means are placed at the dead man's disposal his boats and his slaves; he is provided with cattle and game-birds in the same way as was effected in later times by the use of sepulchral figures and funerary paintings and bas-reliefs. The most likely confirmation of this interpretation is the existence of one tomb, unique up to the present and discovered at Hierakonpolis in Upper Egypt, where we find developed and amplified as mural paintings the usual themes of pottery decoration. (I 5) Here again the big boats occupy the greater part of the wall (on one of them a man works the rudder); in the free space are 
depicted scenes of hunting and battle. By means of the pottery found in the tomb the sequence date 67 can be approximately established. We are thus somewhere near the date at which the primitive series and the Ist dynasty converge. One might almost ask oneself whether the paintings in this unique tomb of Hierakonpolis have not the right to be considered as a debased imitation of the fine tombs of the Pharaonic age which we shall meet with under the Ancient Empire. One detail perhaps gives, in this connection, a very precise indication. In the lower angle is a man, upright, who lifts his arm and brandishes a club above three tiny squatting figures who appear to be bound. This is the "caricature" of the scene we have already met with in the first Egyptian monument we studied, namely, the palette of Narmer. The Hierakonpolis tomb thus gives a crude rendering of one of the most persistent and immutable themes of Pharaonic art. One is tempted to see likewise in the paintings of boats on the pottery a naive representation of the great Egyptian vessels which the inhabitants of Upper Egypt were wont to see navigating the stream during the period of conquest in their country.

There are still some objects bearing engraved pictures which must be noticed. The most typical examples, perhaps, are great flint knives with decorated handles of ivory or gold. One of them, in the Cairo Museum, with its handle made of a sheet of gold-leaf, is decorated with engravings. (I6) On one of the faces two serpents are intertwined, and in the free space between the coils of their bodies the designer has inserted floral devices, evidently with the dislike of empty spaces which is so well known amongst all primitive peoples. On the reverse side is a procession of real and fantastic animals which proceed from the bottom to the top. We shall presently come across similar representations on ivory handles.

It now remains to examine a final class $o^{\prime}$ objects-the slate palettes. These palettes, of which the object or use is not quite certain and which may perhaps most fittingly be called magical instruments, (I 7 ) present either geometrical 
or animal forms. Amongst the animals the most frequent are the antelope, fishes, tortoises and birds. If, in most cases, the animal is identifiable at first sight, in others we find derivations more and more remote from the primitive type. These palettes had entirely disappeared from Egypt in historic times. They survive in Nubia up to the first dynastic age, but in a completely atrophied form. It would therefore appear that these objects owe their origin to beliefs and customs peculiar to the inhabitants of Upper Egypt. However, the excavations at Hierakonpolis yielded, in the most ancient deposits, decorated slate palettes, one of which is no other than the great palette of King Narmer. It bears the king's name at the top of both faces, written in hieroglyphs. This discovery enables us to assign to a definite epoch several fragments scattered in different museums, the dating of which had been the object of much discussion. We will refer to them again in the next chapter when studying the problem of the origin of Egyptian Pharaonic art.

\section{BIBLIOGRAPHY.}

I. Capart, J., Primitive Art in Egypt. London, 1905.

2. Petrie, W. M. F., Diospolis Parva, London, Igor, pl. V.

3. Ibid.

4. Reisner, G. A., Work of the University of California at El-Ahaiwah and Naga-ed-Dêr, in the Archceological Report of the Egypt Exploration Fund, I 900-190I, p. 23, fig. 3 .

5. Reisner, G. A., The Early Dynastic Cemeteries of Naga-ed-Dêr, Part I., Leipzig, 1908, pl. I6.

6. Ibid., pl. 4 .

7. Petrie, W. M. F., Abydos, Part II, London, 1903, pl. LXIV.

8. Reisner, G. A., Archaological Survey of Nubia, Report for 1907-8; Archeological Report, Cairo, I910. Firth, C. M., Report for I908-9, Archaological Report, Cairo, I9I2.

9. Petrie, W. M. F., Diospolis Parva, London, I90r, p. 23 and pl. IV.

Io. Petrie, W. M. F., Abydos, Part I, London, I902, pls. XVIII-XIX.

I1. Capart, J., Primitive Art in Egypt, London, 1905, chap. iv.

I 2. Morgan, J. de, La Barque des Morts chez les Egyptiens prédynastiques, in the Revue anthropolgique, t. xxx., 1920, pp. 272-82 and fig. 22.

I3. In Naqada and Ballas, London, i 896, pl. LXVII.

I 4. Newberry, P. E., List of Vases with Cult-Signs in the Annals of Archaology and Anthropology, Liverpool, t. v., Pp. 137-42; Notes on Some Egyptian 
Nome Ensigns and their Historical Significance, in Ancient Egypt, t. i., Igr 4, pp. 5-8, where the quotation to the Annals must be corrected, vol. v., p. I 32 . I 5. Quibell, J. E., and Green, F. W., Hierakonpolis, London, I902, t. ii., pls. LXXV-LXXVIII.

16. Quibell, J. E., Archaic objects (Catalogue général au Musée du Caire), Cairo, I905, t. i., p. 237 ; Currelly, Ch. T., Stone Implements, Cairo, I9 3 , pl. XLVII.

17. Capart, J., Les Palettes en schiste de l'Egypte primitive. Brussels, Ig08. 


\section{CHAPTER IV}

\section{THE FIRST PHARAONIC MONUMENTS}

SERIES of successful excavations has led to the
discovery of monuments belonging to the earliest
dynasties : Hierakonpolis in Upper Egypt, Naqada several miles north of Thebes, Abydos with its ancient temple and necropolis - all these sites have proved themselves to be of the utmost importance for the study of the first stages of civilisation of Pharaonic Egypt. To these we might add Toura on the right bank of the Nile, and Tarkan on the left, both in the region of Memphis.

On looking through the memoirs in which scholars have published the results of their researches in these localities, one is at once struck by the perfect concordance of the objects brought to light. On the lines of the study which we made in the preceding chapter, we shall begin by establishing the identity of types, a particularly striking feature in the case of pottery. For there is, in fact, no one ware characteristic of Hierakonpolis, another of Abydos, a third of Memphis; on the contrary, in the whole Nile Valley one and the same "fashion" is followed by the potters. It probably came into existence at a central spot whose influence was sufficiently strong to carry it in all directions.

The same general identity is likewise perceived in the forms of the architectural monuments, a point which is very apparent in the tombs of the Ancient Empire.

We may notice, however, for the moment the great tomb of Naqada, which the inscriptions enable us to place at the beginning of the Ist dynasty. (I) The upper part of the walls is lost, but enough remains to prove that the 
exterior sides of the tomb presented a curious arrangement of pilasters forming projections with niches let in, a feature which occurs again and again in the course of the study of Egyptian architecture.

Among the most important objects preserved in these archaic deposits are fragments bearing royal names. The first, already known to us, is the palette of King Narmer (Menes?), which we must now examine more closely. (2) On the principal face (that upon which the figures are largest) the central part is occupied by a group to which attention has already been directed; the king wears the crown of Upper Egypt; he raises a club with which he is about to strike a conquered foe kneeling on the ground. Behind the king is a serving-man bearing his sandals. Above the head of the victim a symbolic group signifies that the falcongod Horus has granted the king victory over six thousand enemies. On the other face, the field of the palette is divided into several registers. In the first we witness a ceremony : the king, decked this time with the crown of Lower Egypt, advances accompanied by a sandal-bearer and preceded by a high functionary. The procession, which moves towards a group of decapitated bodies, is headed by four bearers carrying ensigns. Below, two feline animals stretch and intertwine their necks in such a way as to enclose a circular space. The two fantastic animals are held in leash by two men who occupy the free space above the beasts. At the bottom a bull treads a vanquished enemy underfoot and destroys with its horns the walls of a fortified town. The two fugitives at the foot of the principal face would appear to belong to this scene. Here, indeed, we have before our eyes a representation which is purely Egyptian, showing that the costumes, attributes and attitudes of later periods were already quite in use. Several hieroglyphs, amongst others the king's name thrice repeated, demonstrate the employment in such remote times of this peculiar system of writing.

The style of the palette has not yet reached the standard of other monuments of the same age which we shall presently deal with; we can easily perceive the awkwardness and 
the stiffness of some of the figures; but an explanation of this will be given later on. The same defects in style can be seen elsewhere in the bas-relief of King Mersekha or Semerkha, carved at a great height on the rocks at WadyMagara in Sinai. (3) Here three large royal figures are set out side by side : on the left, a repetition of the principal group of the palette, the king is preparing to immolate his vanquished enemy; before this group the figure of the king, twice repeated and differing only in the crown (in one case that of Upper Egypt, in the other of Lower Egypt). It is well to note that in this group the triumphant king is also wearing the crown of Upper Egypt, which implies the supremacy of this part of the country over the other.

The stele of the Serpent King (4) affords us an instance of the highest perfection coupled with extreme simplicity. A light frame follows the outline of the stone and shows up the royal name there engraved : in fact, the entire decoration of the stone set up in the king's tomb confines itself to giving us his principal name. The Egyptian kings of classic times had five names corresponding to different titularies; the most important, that which we have here, is called the Horus name. A falcon, the bird sacred to Horus, perches upon the upper part of a rectangle in which is inscribed the king's name. The lower part of the rectangle is occupied by a curious complex of horizontal and vertical lines which immediately recalls the arrangement of the walls of the royal tomb of Naqada. But this question will be followed up in detail later on.

In the ruins of the temple of Hierakonpolis a granite fragment was found, doubtless a door-jamb, which repeats several times the name of King Khasekhemui, of the IInd dynasty. (5) Here again we recognise the general arrangement just described, but with this difference : the rectangle is surmounted, not by a falcon only, but by two animals symbolising the two parts of Egypt-the falcon and the still unidentified animal of the god Seth. This is a way of expressing that the king re-united under one sceptre after a period of division "the two parts, of Horus and of Seth," as the texts frequently say. The same King 
Khasekhemui (or one of his predecessors called Khasekhem) is known by two statues found at Hierakonpolis. (6) We may note in passing that, in spite of their mutilations, they present the fundamental characteristics of the royal sculpture of the following dynasties; were it not for the evidence of the inscriptions it is probable that archæologists would feel some hesitation in assigning them to so remote an age.

At the level dated by these monuments, excavators have discovered at Hierakonpolis and at Abydos great quantities of fragments worked in ivory : the testimony of the inscriptions carved upon some of them enables us to affirm that the whole collection certainly belongs to the earliest dynasties. These ivories, unhappily very mutilated, display the existence of figures of men or of animals of very finished workmanship. But few examples need be cited. One fragment in the Oxford Museum is the upper part of the body of a woman, (7) whose shoulders are covered by long wavy locks; in spite of its mutilations it shows perfect execution. We can see that the sculptor's chisel has carefully studied the shape of the head, and has succeeded in rendering the features in a most expressive manner. The eyes, which were made of some other material, have unfortunately disappeared, leaving two gaping sockets in the midst of the face. We may compare with it a minute figure of only a few centimetres in height preserved in the British Museum : (8) it is a king of Upper Egypt wrapped in a long embroidered cloak. The injuries of time have altered the surface of the ivory, but not too much to prevent us from appreciating the delicacy of the workmanship and the intense realism which characterises it.

The part played by these little figures has not been determined with certainty, but they may have been, after all, ex-voto offerings in the temples or funerary figures destined for the tombs. We do know, however, the purpose of the figures of dogs, lions and lionesses which have been found in the tombs of several localities. They are gaming-pieces, and to be convinced of this we have but to compare the lion and the dog from the royal tomb of Naqada (9) with the painting of a box of games in the tomb of Hesi at Saqqara. (beginning of the IIIrd dynasty). (IO) These little images 
all testify to great dexterity in seizing the characteristic forms of the animals.

These same tombs contained fragments of furniture. They give us a striking example of the stylisation of an object of daily use which was so successful that the Egyptians adhered to it with scarcely any change until the latest epochs of their history. We will examine two chair-legs found in the tomb of Naqada, which are wrought in the form of the legs of a bull. (I I) One is a fore-leg, the other a hind-leg; both rendered with the greatest fidelity. The piece of furniture was supported by the animal, or indeed represented the animal itself, standing normally upon its four feet, two before, two behind. The necropolis of Abydos has yielded a whole series of identical, or similar, pieces. It will be noticed that in one series of examples the legs of the bull are more bent, as if the animal were weighed down beneath its load. (12)

Similar objects have been recovered, entire or fragmentary, from all the Ist dynasty sites: they show a wellfinished type which was handed down to the Egyptians of posterity in a form wellnigh unchangeable.

Objects in faïence, enamelled sometimes in a single colour, sometimes in several colours, are everywhere met with; there are the figurines, vases, glazed tiles for wall decoration, etc., (I3) the very abundance of which proves that we are dealing with a craftsmanship which has left its tentative stages far behind and has adapted itself to the requirements of widely different uses. It is at the same time one of the most typical industries of Pharaonic Egypt. In some of the primitive tombs of Upper Egypt collars of enamelled beads have been found, but these same burials contain, more by exception than by rule, an occasional object of copper. Their presence there is to be explained apparently by commercial intercourse, and enamel, like copper, immediately indicates one and the same origin. It is to Sinai that the Egyptians of the most ancient periods went to exploit the copper mines, and the Egyptian enamel is, as is well known, derived from copper.

Before going farther it is well to inquire what conclusions 
emerge from the mass of dated objects examined up to this point. There is no possibility of confusion between the group of documents found at Hierakonpolis and in the royal tombs of Abydos on the one hand, and the mass of objects from Upper Egypt which are studied in the previous chapter. These are quite another matter, the product of quite another civilisation. One is led from this to the problem already mentioned: whence came the wave of civilisation which altered the aspect of the objects discovered in Upper Egypt since the second period of the primitive epoch?

The complete civilisation which now appears to us as being in possession of very developed art is further characterized by a system of writing which is already fully constituted. We may quote in this connection the remarks of several scholars. Professor Steindorff says: "The formation of hieroglyphic writing goes back to prehistoric times; already on the inscriptions of the royal tombs of Abydos-that is to say, the most ancient historical monuments-we come across Egyptian writing as an accomplished fact which, in the course of later ages, will have to undergo but a minimum of modification." (14) Professor Sethe of Göttingen expresses himself as follows : "Under Menes and his successors, the kings of the first historic dynasty, we find Egyptian civilisation completely evolved, and even, in a sense, having reached its culminating point. In particular, the writing has developed as completely as possible from the pictographic writing from which it originated, towards its transformation into phonetic writing which must certainly have been in use for some centuries." (I 5). Again, it was in Egypt itself that hieroglyphs came into being. In the opinion of Professor Griffith of Oxford " the ancient Egyptian system of writing, so far as we know, originated, developed, and finally expired strictly within the limits of the Nile Valley. The germ of its existence may have come from without, but as we know it, it is essentially Egyptian and intended for the expression of the Egyptian language." (I6)

We are bound, then, to admit a historic period before 
the Ist dynasty. The Egyptians cherished the memory of it, and for them the Ist dynasty was not the startingpoint of their history, but only of the history of a reign which united Upper and Lower Egypt under one sceptre. When they related the beginnings of their existence they described the reign of the gods upon earth. Then, when the gods had ceased to rule, they bequeathed their power to numerous kings before the time of Menes. The historical fragment of Palermo contained lists of these kings of Upper and of Lower Egypt. The Turin papyrus, as well as Manetho, preserve traditions of successive families of kings anterior to the Ist dynasty. Without entering into the details of these questions, I will content myself with quoting the conclusion of the historian Ed. Meyer : (I 7) "There is no question here of the interpretation of a later age, but of a very ancient tradition. In the royal papyrus of Turin, preserved only in fragments, it seems that the gods were succeeded first of all by a dynasty of more than a thousand years' duration, then by twenty kings with a period of eleven hundred years, then by ten the number of whose years is lost, then by others again of which only the number of years has been preserved, three hundred and thirty; then ten kings with more than a thousand years, then nineteen sovereigns of Memphis who reigned only eleven years, four months and twenty days; and nineteen kings of the northern country with more than two thousand one hundred years, and finally the dynasty of 'Worshippers of Horus,' with over thirteen thousand four hundred and twenty years. According to Manetho, after three dynasties of gods or demi-gods, follows first a certain number of kings with one thousand eight hundred and seventeen years, and then thirty Kings of Memphis with one thousand seven hundred and ninety years, ten Kings of Thinis with three hundred and fifty years, and finally the genii who correspond to the 'Worshippers of Horus,' with five thousand eight hundred and thirteen years. In spite of differences in detail, it will be observed that the general scheme is the same."

For fuller information I must refer the reader to my study, published in I9 I 4, on The Origins of Egyptian Civilisa- 
tion, (I 8 ) in which I discussed the arguments which seemed to me to show that this history before the Ist dynasty could be placed almost entirely in Lower Egypt. It happens that archæological discoveries in Upper Egypt have been very rich in a number of places, yet, side by side with the civilisation of the indigenous peoples, no traces whatever have been found of a Pharaonic civilisation before the development of the Ist dynasty. It might be supposed that the documents of the transition period still lie hidden in the burial-grounds which have up to the present escaped the attentions of archæologists, but the series of pottery has shown in a concordant manner that perfect continuity has been maintained. It will be remembered that in the last chapter it was pointed out that the Ist dynasty attaches about the sequence date 75. If long lines of kings had reigned in Upper Egypt before Menes, it is strange, to say the least of it, that nowhere in the primitive burials have hieroglyphic inscriptions been found, although they abound when the Ist dynasty tombs are opened.

There is, however, one historical fact that must certainly be taken into account, and that is the superiority which Upper Egypt exercised over Lower Egypt in historic times. It is likewise quite certain that at the dawn of the dynastic era Upper Egypt had conquered Lower Egypt. It is probable that Egyptian chiefs, firmly established in Upper Egypt, had at some given time conquered the Delta, which was the birthplace of their race. Here we have the first example of an event which repeated itself several times in the course of history. Thus, after the Ancient Empire the Theban princes gained ascendancy over the Herakleopolitan kings, and founded the Middle Empire, whose authority extended all over Egypt. In the same way, in the XVIIth dynasty, the Theban princes expelled the Hyksos. (19)

It is to a period first of struggles for freedom and then of conquest that the slate palettes belong, monuments which seem to be rather what we may perhaps term "imitatives." The Hierakonpolis specimen, in the name of Narmer, fixes with certainty the date of the whole series. 
At several periods in the history of Egyptian art we come across groups of rude and clumsy monuments whose " imitative character" is absolutely undeniable. The earliest Theban sovereigns to the XIth dynasty made lamentable copies of the artistic productions of the Ancient Empire. It was not until the time when their power was firmly established over the whole of Egypt that they had access to good models and to good workshops, and began their series of masterpieces. (20)

We will now examine the most important palettes and fragments of palettes.

A complete specimen was found at Hierakonpolis at the same time as that of Narmer. (2 I) The edge is adorned with figures of animals; in the field are scattered pêle-mêle representations of animals, both real and fantastic, pursuing one another. On the obverse, the centre of which is occupied by a cavity, the figures are of the same character: we see again two feline animals with serpentine necks, one on either side of, and detached from, the cavity. If they are deprived of their decorative motive, these necks have no point whatever. One might almost see here a clumsy imitation of one of the motifs of the great palette. The unfortunate animal reappears on a specimen in the Louvre, (22) but this time it is set far from the cavity and walks on the field of the object. On one of the faces is seen, rudely interpreted, a design figuring a palm-tree flanked by two giraffes.

The fine fragment in the British Museum (23) (completed by an Oxford fragment) might pass as having served as the model for the Louvre palette. Here the forms of the giraffes are drawn with the precision and care which characterise the fine animal drawings of the Egyptians of the Ancient Empire. On the reverse of the palm-tree and giraffe scene is depicted a battle episode. Once more we see the slain enemies lying on the ground, whilst a lion and some birds of prey come to tear them. The drawings are of unequal merit : the lion is not of such pure execution as the giraffes, but the corpse which is being devoured by the beast is drawn with real perfection. The Oxford frag- 


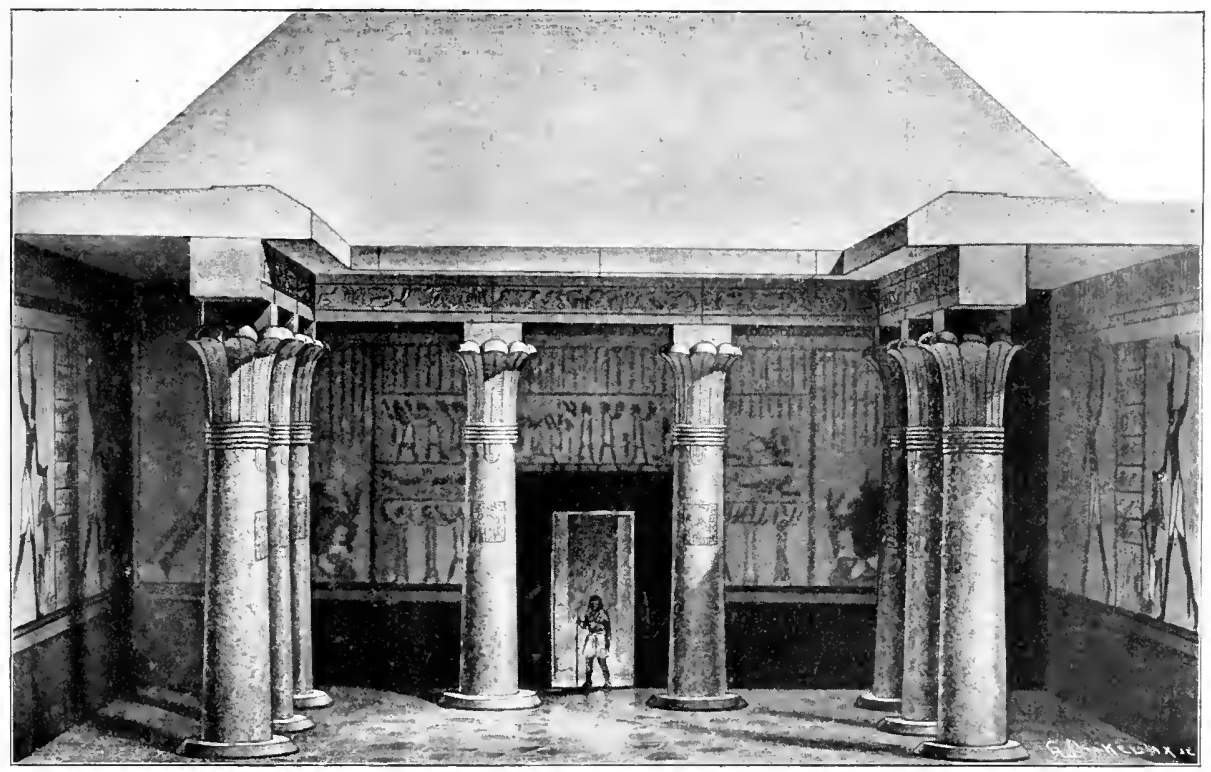

CENTRAL COURT OF THE PYRAMID-TEMPLE OF SAHURE, AS RESTORED BY BORCHARDT 


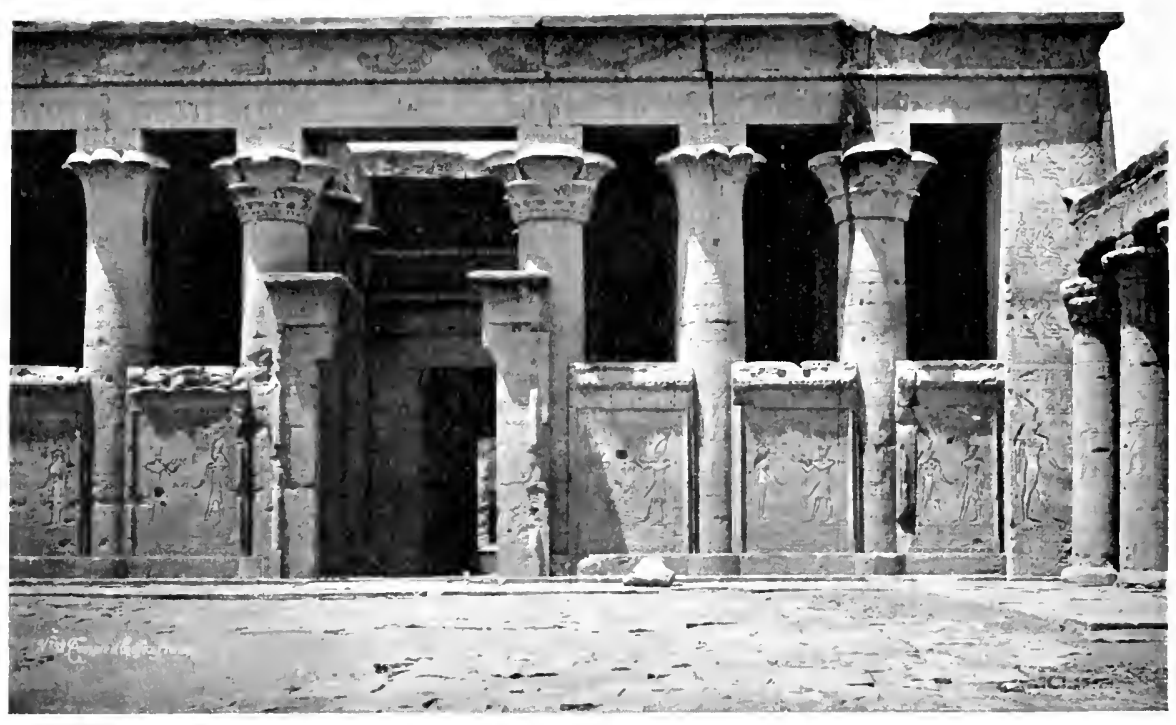

PRONAOS OF THE TENPLE OF HORUS AT EDFU 


\section{THE FIRST PHARAONIC MONUMENTS 65}

ment (24) represents two more enemies led captive and escorted by standards similar to those which we have examined on the palette of Narmer, or on the stern-ends of the barges painted on the primitive pottery. Similar standards are also carried by the hunters depicted on the palette, of which two fragments are in the British Museum and a third in the Louvre. (25) The animals tracked by the two bands of warriors are in all respects similar to those represented on several of the previously mentioned palettes.

A fragment in the Louvre (26) is closely allied to the palette of which one part is in the British Museum and the other at Oxford. Here the standards are represented " in action" seizing a rope " in their hands." The upper part of this fragment is occupied by a bull goring an enemy, which recalls one of the episodes in the Narmer palette. It will be observed that the feet of the bull are stylised in the same manner as the feet of the furniture which we dealt with earlier. On one face, crenelated enclosures, in which are hieroglyphic signs, indicate the names of the towns vanquished by the conqueror.

Finally a fragment in Cairo (27) details on one face a whole series of names of towns, and on the other are set out spoils brought from Libya. (28) Three successive registers show sheep, asses and bulls. These animal figures are so crude and rough that the whole production looks like a lame copy of a good original. It may be compared with a bas-relief in the temple of Sahure, of the Vth dynasty, at Abusir. (29) Here again is seen set out spoils taken also from the Libyans, and the series of animals arranged in successive registers exactly reproduces sheep, asses and oxen in the same order as the Cairo fragment.

Representations which could likewise be called " imitative" are found on a certain number of utensils and various other objects : such is the knife in the Cairo Museum, with its handle of engraved gold; such also is the ivory comb in the Davis collection. (30)

We must also note the flint knives with ivory handles, the most important specimen of which is in the Louvre. (3I) If these flints are to be ranked with the wonderful neolithic 
implements of Upper Egypt, dated in Petrie's "Sequence Dates" about 60, and are consequently to be included amongst indigenous manufactures, the sculptures of the handles-the thematic character of which has been so ably demonstrated by Benedite (32)-find their continuation in the series of ivories from Hierakonpolis belonging to dynastic Egyptian art. The knife of Gebel-el-Arak deviates so much from the manner characteristic of the civilisation of Upper Egypt that some writers would seek for its origin outside the Nile Valley, as far off, indeed, as Elam (33). It presents, however, nothing which would exclude it from the scheme of Pharaonic civilisation. (34)

We will now leave these documents, which imitate in a more or less clumsy fashion the productions of a more accomplished art, and revert to the question of Egyptian art as it appears clearly in dated documents of the earliest dynasties. In his book on Egyptian Art in the "Ars Una" series Maspero expresses himself as follows : (35) "When the Memphite dynasties arose (the IIIrd dynasty is the first Memphite) it (art) was already in full possession of its ruling ideas, its conventions, its formulx, its technique, all the features which gave it originality and character." This clear and concise statement we may take as a sure guide, but we will, however, add one remark further, and that from henceforth Egyptian art teids to crystallise into formulæ; in reality its period of formation and progress is left behind, it can only remain stationary or deteriorate. If we seek the cause of this fact, we shall most probably find it principally bound up in the influence of religion. Art is inherent in the service of the religious and funerary rites which the Egyptians had inherited from their forefathers and which they had the greatest scruples in modifying. For thousands of years they repeated the same acts, dictated by the ritual which passed almost without alteration from age to age.

Without insisting now on these ideas, which would involve us in considerable elaboration, it is needful to illustrate by a few examples the persistence of forms and motives.

The royal tomb of Naqada is adorned, as is well known, 
by projecting pilasters and recessed niches. This architectural arrangement passes on throughout the ages. Professor Meyer remarks that "were it not certain, from the evidence of the objects found, that this tomb dates from the time of Menes, we should certainly place it at a later date-the commencement of the IIIrd dynasty." (36) As a matter of fact, the tombs of this epoch supply us with a whole series of very characteristic examples. Two tombs of the Vth dynasty at Saqqara reproduce in stone, at the end of the chapel, the general arrangement of the exterior walls of the Naqada tomb. In the latter monument the upper part of the walls has disappeared. Here, on the contrary, in the tombs of Sabu (37) and of Niankh-Re, (38) the upper decoration is composed of two flowers or two leaves. This feature, which likewise figures on the architectural portion of the stele of the Serpent King, proves by the evidence that the bottom of the rectangle containing the royal name really has the value of a monumental design. Its forms, the origin of which will occupy us in the next chapter, are preserved throughout the ages, and, by way of a typical example, it is sufficient to observe that the Horus name of King Sesostris I, of the XIIth dynasty, in the pyramidtemple at Lisht, copies them exactly. (39)

But it might be objected that we have to do with a stereotyped model which has been repeated indefinitely by pure tradition, as forming an integral part of the royal protocol. We will, then, take another case, which deals with an architectural element which might be called living, in the sense that nothing prevents its being altered. The pyramid-temple of Sahure at Abusir furnishes the oldest example in the nature of a dactyliform capital ; that is to say, decorated with palms. (40) The tomb of Tehuti-hetep at El-Bersheh, of the XIIth dynasty, shows us a column whose capital is identical with that of the Vth dynasty. (4I) At Tell-el-Amarna, the ruins of the palace of Amenophis IV, of the XVIIIth dynasty, once more give us an identical capital. (42) If we pass over a long period to the GræcoRoman age, the pronaos of the temple of Edfu demonstrates that the old model had not ceased to be used, and the archi- 
tects contented themselves with copying it as nearly as possible. (43)

The same may be said of a pictorial motif. In the temple of Sahure is represented a procession of personages bearing tables of offerings for the deceased king. (44) We see there men and women bringing their tribute to the royal tomb: some of them have above their heads hieroglyphic signs denoting the different regions or provinces from which they have come. The men have a peculiar aspect, recalling the form which the Egyptians gave to the Nile-god, and for this reason these men are often spoken of as "Niles." The fleshy parts of these beings are fat, thereby indicating abundance and riches. The breast is strongly accentuated, the belly protrudes in heavy folds of fatness; the clothing is reduced to a mere girdle, from the front of which are suspended flaps of cloth forming a kind of fringe. A monument of the XIIth dynasty, the granite table of offerings from the temple of Sesostris I at Lisht, repeats this procession of "Niles" in the same attitude and form. (45) At the beginning of the XVIIIth dynasty, in the temple of Deir-elBahari, (46) we come across the series of men and women figured in the same manner, with the geographical standards once more above their heads, and although the sculptor has given these figures neater and more slender contours, at the same time he has not failed to indicate the distended breasts of the Nile figures, nor yet to draw the belly bulging over the girdle, thereby reducing the loin-cloth to a mere hanging fringe. The temple of Seti I at Abydos, of the XIXth dynasty, supplies some fine examples of these pictures of "Niles," this time in a kneeling attitude. (47) One might quote countless other instances, of which none departs from the general rule, although many of these figures, at a later date, show plainly the deplorable decline in the art of drawing in Egypt. Thus it is that the "Niles" in the cella of the temple of Kalâbshi, (48) built by the Emperor Augustus, repeat the same idea, but render it clumsily and carelessly.

In connection with these processions of offering-bearers it is curious to compare a picture of the Ancient Empire 
with another of the Roman period. In the one we see the staid and severe outlines in the tomb of Ptah-hetep II, (49) of simple and sure draughtsmanship ; in the other, a female offering-bearer at Kom-Ombo, ( $5 \mathrm{c}$ ) heavy, gross and so overloaded with detail that it would seem as though the artist were afraid to leave a single inch of the stone unused. The rule is visible equally in the one and in the other, and it would seem that both cases were inspired by a single original model, but the execution differs to such a degree that one would scarcely venture to say, on comparing the two monuments, that Egyptian art had never changed at all in the course of its age-long history.

But the most striking example of artistic forms, fixed in early times and persisting, is certainly that furnished by the hieroglyphic system. As is well known, the hieroglyphs form a script in which all sorts of beings and objects are represented : men, animals, plants, buildings, furniture, divers utensils, etc., etc.

If the origin of this writing be considered from the artistic point of view, two hypotheses present themselves. The first, which I hasten to declare absurd, is the following : that writing initiated art ; that is to say, that a people having formed the idea of representing their ideas by pictures would by this means have acquired the material for graphic pictures which would only have to be increased to put their owners in possession of an almost complete art. The other hypothesis, evidently the only acceptable one, is at the same time full of important considerations. The invention of pictographic characters could have been possible only among people whose artistic develcpment was sufficient to give them the conception of fixing their ideas for their contemporaries as well as for posterity by means of picture writing. In this case the very forms of hieroglyphs themselves bear valuable witness to the artistic level which the Egyptians had attained at the time when the system was inaugurated.

It will be remarked that the hieroglyphs show precisely that use of conventions which the Egyptians employed in historic times : although they generally drew the figures in 
profile, they represented as full-face such details as would not be adequately represented by the silhouette: such as the head of the owl, the tails of the birds, the wings of a bird in flight, or the shoulders of a man. They drew the whole picture in plan when dealing, for example, with a lizard, or a scorpion, which are, so to speak, quite flat animals of which a silhouette would not be sufficiently characteristic.

We must not forget that the hieroglyphs, when we first meet with them on the Ist dynasty monuments, have no longer the simple pictographic value which they had originally. They have acquired phonetic values which postulates, as Professor Sethe pointed out, a previous usage of several centuries. We can thus see that, by arguing from the hieroglyphs, we can push far back into the past for the origin of artistic forms, which were already completely fixed at the beginning of the Ist dynasty.

A number of illustrations of hieroglyphs, taken from different periods, show to what extent the characters of this writing, which is above all monumental, have been precisely conserved. The quadrupeds in the tomb of Ptah-hetep I, of the Vth dynasty (5 I) -antelopes, oxen, asses, sheep-are outlined with remarkable knowledge and precision. One may say the same of the birds-eagles, falcons, owls, etc. (52) For the Middle Empire we may take as examples the birds of Beni Hasan, (53) then the various signs in the tomb of Tehuti-hetep at El-Bersheh. (54) As to the New Empire hieroglyphs, in the temple of Deir-el-Bahari, (55) the forms are still the same throughout, and we may be sure that they were designed from the same patterns, handed down from generation to generation. In the Saïte period models of hieroglyphs are often found engraved on soft stone. (56) A falcon of this period may be profitably compared with the falcon on the stele of the Serpent King. (57)

When we come to look at the miserable hieroglyphs of the temple built by the Emperor Augustus at Dendur, in Nubia, (58) we are appalled by the lamentable caricatures produced by the sculptors, who were nevertheless in the service of the great Roman Emperor. If we knew nothing of the chronology of Egyptian monuments, might we not 
be inclined to believe that the Dendur hieroglyphs are rude and clumsy attempts, preceding by several centuries the fine and noble figure of the falcon on the stele of the Serpent King?

This, in short, we may say is the whole history of Egyptian art. We determine, in fact, between the Ist dynasty and the Roman epoch the various periods when after a brilliant display the best traditions undergo a spell of relapse or even eclipse; then we consider the final and hopeless decadence of the Roman epoch, when everything decisively fades away, and we then have a brief indication of the manner in which are to be solved the broad lines of the historical problem raised by the art of ancient Egypt.

It may not be out of place, finally, to cite a very curious example of the persistence of a craft which has remained immovable and has resisted the vicissitudes of the ages. In a tomb of the Ist dynasty at Tarkan, Professor Petrie found a fragment of matwork, which he placed on a modern Egyptian mat. (59) The photograph, which depicts the two specimens side by side, proves the extent to which, when no need for change arises, Egypt is capable of conserving for more than sixty centuries an unchanging tradition.

\section{BIBLIOGRAPHY.}

I. Borchardt, L., Das Grab des Menes, in the Zeitschrift für ägyptische Sprache, t. 36 (1898), pp. 87-105, with 5 plates.

2. Capart, J., Primitive Art in Egypt, figs. I 83-4.

3. Petrie, W. M. F., Researches in Sinai, London, I906, pl. XLII; Gardiner, A. H., and Peet, T. E., The Inscriptions of Sinai, Part I, London, I 9 I 7, pl. I, I $a$.

4. Bénédite, G., La Stele dite du roi Serpent, in the Monuments Piot, t. xii., I905, pp. 5-18, and pl. I.

5. Quibell, J. E., Hierakonpolis, Part I, London, I900, pl. II.

6. Ibid., pls. XXXIX-XLI.

7. Capart, J., Primitive Art in Egypt, p. I7 I, fig. I 33, No. 3.

8. Ibid., fig. I 22.

9. Morgan, J. de, Recherches sur les Origines de l'Egypte. Ethnographie primitive et tombeau royal de Négadah, Paris, I897, figs. 698, 699, p. I 92.

ro. Quibell, J. E., The Tomb of Hesy (Excavations at Sagqara, I9I I-I 2), Cairo, I9I3, pl. XI.

I I. Capart, J., Primitive Art in Egypt, fig. 107. 
12. Amelineau, E., Les Nouvelles Fouilles d'Abydos, 1895-6. Compterendu in exienso, Paris, I 899, pl. XXXII.

13. Petrie, W. M. F., The Arts and Crafts of Ancient Egypt, London, I 909, pp. I08 seq.

14. Myers-Lexikon, Hieroglyphen, p. 3 I 5.

I 5. Sethe, K., Beiträge zur altesten Geschichte Aegyptens: I. Die "Horusdiener," in the Untersuchungen zur Geschichte und AltertumskundeAegyptens, t. iii., Leipzig, I903, p. I I .

16. Encyclopedia Britannica, I t th edition, s.v. Egypt, p. 6I.

17. Meyer, E., Geschichte des Altertums, I, 2, 3 rd edition, Stuttgart and Berlin, I9I 3, p. I०2.

I 8. Capart, J., Les Origines de lo Civilisation égyptienne, Bruxelles, I9I4· Reprinted from the Bulletin de lo Societe d'Anthropologie de Bruxelles, t. xxxiii.

I 9. The same process has been revealed in the case of the $X X V$ th Ethiopian dynasty by the recent excavations of Reisner. See Discovery of the Tombs of the Egyption XXVth Dynasty at El-Kurru in Dongola Province, in the Sudan Notes and Records, t. ii., I 919 , pp. 247 and sqq.

20. Compare the reliefs in Naville, E., and Hall, H. R., The Eleventh Dyrasty Temple at Deir-el-Bahari, Part I, London, 1907, and the relief of King Se-ankh-ka-ra in the Abbott Collection; Williams (Mrs.), Two Reliefs in the Abbott Collection, in the New York Historical Society, Quarterly Bulletin, t. ii., I 9 I 8, pp. I4-2I, with 2 figs.

21. Capart, J., Primitive Art in Egypt, figs I7 I, 172.

22. Ibid., figs. I73, 174 .

23. Ibid., figs. I 79 , I 80 .

24. Ibid., figs. 177,178 .

25. Ibid., fig. I70.

26. Ibid., figs. 181,182 .

27. Ibid., figs. 175,176 .

28. Sethe, K., Zur Erklärung einiger Denkmäler aus der Frïhzeit der ägyptischen Kultur, in the Zeitschrift für ägypt. Spr., t. lii., I9I4, pp. 55-60 and 3 figs.

29. Borchardt, L., Das Grabdenkmal des Königs Sa'hu-re', t. ii., Die Wandbilder, Leipzig, I 9 3 , pl. I and p. I 3 .

30. Bénédite, G., The Carnarvon Ivory, in the Fournal of Egyptian Arche. ology, t. v., I9 18, pl. XXXIII.

3. Bénédite, G., Le Coutear de Gebel el-'Arak, in the Monuments Piot, t. xxii., I9 16, FP. I-34, with pl. I.

32. Bénédite, G., The Carnarvon Irory, in the Fournal of Egyptian Archaology, t. v., I 918, pp. I-I 5, 225-4I, with pls. I, XXXII-XXXIV.

33. Petrie, W. M. F., Egypt and Mesopotamia, in Ancient Egypt, I917, pp. 26-36, with i 2 figs.

34. Capart, J., Le "Pseudo-Gilgamesh" figuré sur le couteau egyptien de Gebel el-'Arak, in the Comptes-rendus des seances de l'Academie des Inscriptions et $B$ lles-Lettres, I919, pp. 404-18, with 7 figs.

35. Maspero, G., Ars Una, Egypt, English Edition, I921, p. 23.

36. Meyer, E., Chronologie egyptienne, traduit par A. Moret, Paris, I 912

18 I n. 2 . 
37. Mariette, A., Voyage dans le Haute-Egypte, Cairo, I878, t. i., pl. 5.

38. Ibid., pl. 8.

39. Gautier, J. E., and Jéquier, G., Mémoire sur les Fouilles de Licht, in the Mémoires de l'Institut frangais d'archeologie orientale, Cairo, 1902, fig. 6, p. I 2.

40. Borchardt, L., Das Grabdenkmal des Königs Sa'hu-re', i., Der Bau, Leipzig, 1910, pl. 6.

41. Newberry, P. E., El Bersheh, Part I, London, I894, pl. IV.

42. Petrie, W. M. F., Tell-el-Amarna, London, I 894, pl. VI.

43. Béchard, M., L'Egypte et le Nubie, Paris, i 877, fl. CIX.

44. Borchardt, L., Das Grabdenknal des Königs, $S a^{\prime} h u-r e$, ii., Die Wandbilder, Leipzig, I9I3, pl. 29-30.

45. Gautier, J. E., and Jequier, G., Memoire sur les Fouilles de Licht, Cairo, I902, pl. 8 and pp. 22-6.

46. Naville, E., The Temple of Deir-el-Bahari, Part V, London, 1906, pl. CXXVIII.

47. Capart, J., Le Temple de Séti I, Brussels, I912, pl. XV.

48. Gauthier, H., Le Temple da Kalabchah, Cairo, I9I I, pl. III, and sqq.

49. Mariette, A., Voyage dans la Haute Egypte, Cairo, 1878, t. i, pl. 7.

50. von Bissing, F. W., Einführung in die Geschichte der Aegyptischen Kunst, Berlin, 1908, pl. XXVIII, n. 2.

5I. Davies, N. de G., The Mastaba of Ptahketep and Akhethetep, Part I, London, I 900 , pl. VI

52. Ibid., pls. VII-VIII.

53. Griffith, F. L1., Beni Hasan, Part III, London, I 896 , pl. II.

54. Griffith, F. L1., A Collection of Hieroglyphs, London, I898, pls. VIII, IX.

55. Ibid., pls. I-IV.

56. Edgar, C. C., Sculptors' Studies and Unfinished Works, Cairo, 1906, pl. XXXIV and sqq.

57. von Bissing, F. W., Denkmäler ägyptischer Skulptur, Munich, I 906, pl. $125 a$.

58. Blackman, A. M., The Temple of Dendîr, Cairo, I9I I, pl. CXIII,

59. Petrie, W. M. F., Tarkan I and Memphis V, London, 19i 3, pl. X. Nos. 10, II. 


\section{ARCHITECTURAL HIEROGLYPHS AND KINDRED SUBJECTS}

$\checkmark$ INCE the signs employed in writing have preserved for us pictures which belong to the farthest reaches of Pharaonic civilisation, it is not without importance now to examine such signs as represent buildings or parts of buildings, for therein lies the opportunity of discovering some of the fundamental elements of Egyptian architecture.

Upon a single plate in one of Griffith's works (I) is collected a number of architectural hieroglyphs of the Ancient Empire. The simplest is the plan of a house, traced as a rectangle with an opening in the front part which corresponds to the doorway. In reality it is rather an enclosure than a house. Two variants show on the upper part a series of rearing serpents, which are a frequent border to walls, as we shall see. Two specimens represent a sort of rudimentary labyrinth, constituting a walled enclosure, with a partition, which, whilst concealing the real entrance, forms a sort of corridor. Another sign, thrice repeated side by side, represents a large rectangular enclosure with a smaller construction in one angle. 'This denotes, as a hieroglyph, a castle drawn within a precinct. A crenelated cnclosure contains in its interior a building which the inscriptions call a palace. We next meet with a more complex construction. It is a sort of pavilion the sides of which are covered with intercrossing lines. On the upper part is a cornice, characteristic of Egyptian architecture, and a door opens below. Another similar erection seems to be sheltered by a roof upheld on two forked stakes. We notice the sign for the granary thrice repeated, in the form of a circular construction ending 
in a dome, evidently made of kneaded earth or of clay, or perhaps of bricks. The pyramid is easily recognised, and need not detain us. Two signs depict a sort of kiosk, or tent, supported by a column, the sides of which are drawn in imitation of matting. As a separate part, we observe first of all a column, with a tenon for fitting on its upper end, then two pillars of polygonal form also ending in tenons. In one case, as we see from the illustration, the sides are slightly grooved with parallel channellings.

The stele of the Serpent King (2) depicts an important architectural framework. The rectangle, surmounted by the falcon, and ending at the base in an arrangement of vertical and horizontal lines, occurs over and over again in the inscriptions of offerings in the tombs of the Ist dynasty. The scheme of decoration, however, is sometimes reduced to a few strokes, carelessly drawn. In the example of the Serpent King, on the contrary, the indication of the details is very carefully worked, so that we can discern three towering blocks with doorways between them.

The explanation of several other hieroglyphic signs which are more complex must be worked out in connection with the study of the architecture of the Ancient Empire.

It will be observed from this rapid survey that the buildings represented by the hieroglyphs are, for the most part, simple constructions, implying, above all, the use of soft materials : wood, plaited straw, mud or bricks. The buildings of this kind having disappeared, generally without leaving the slightest traces, we must have recourse to pictured representations of them if we would reconstruct them. Sometimes, however, we have enlarged copies of them made of more durable material. As stone constructions, they have survived to our own days, not easily recognisable at first sight.

Several drawn figures, principally of religious edificestabernacles or sanctuaries-deserve our attention. One wall, in one of the Osiris chambers, in the temple of Seti I at Abydos, supplies us with two such examples. (3) The statue of the god is enclosed in a kind of chapel, the side partitions of which have been omitted, evidently in order that the observer may see what is happening within. Two 
cornices, one above the other, each surmounted by rows of serpents, or urai, mark he positions of the anterior and posterior partitions, or, to be more exact, the lateral walls, since the chapel is viewed from one side. An incurved line passes above the higher cornice and rests in front upon an upright: this indicates the pole on which the roof is supported. The slightly projecting spur in front gives the profile of the cavetto-cornice which spreads over the door. The latter is represented as open, but it is reduced to the size of a narrow board, just sufficient to mark the leaf of the door, without sacrificing any part of the wall-space to drawing the door in its full extent. In the same series of reliefs, just above the preceding, a sacred emblem is seen set up in a similar chapel. The king, as officiating priest, is in the sanctuary, but he stands outside the chapel holding in his hand a censer the end of which penetrates into the interior.

The god Ptah, the chief god of Memphis, is often represented in a lightly constructed shrine, evidently made of wood. In an example, also in the Abydos temple, the details may be plainly seen. (4) This time the door is reduced to a tiny leaf affixed to the upper part of the front roof-support, in such a way as not to hide the figure of the king, whose hands are thrust forward into the interior of the shrine. It will be observed that, by a curious inconsistency, the king's arms are shown in front of the door-post of the chapel instead of behind it. As in the first instance, the side walls are omitted. Elsewhere, as we can see from the treatment of detail, these walls are of woven matting, as in the tomb of Urana II at Sheikh Said (Vth dynasty). (5)

Certain funcrary bas-reliefs acquaint us with the light kiosks, in which the offerings made to the soul of the dead were deposited. These constructions, made of extremely light and fragile materials, were probably set up along the route of the funeral cortège. A bas-relief at Berlin, (6) for instance, shows constructions of this kind, where vegetable elements play the greatest part. The study of the origin of the column will explain certain details of this representation. 

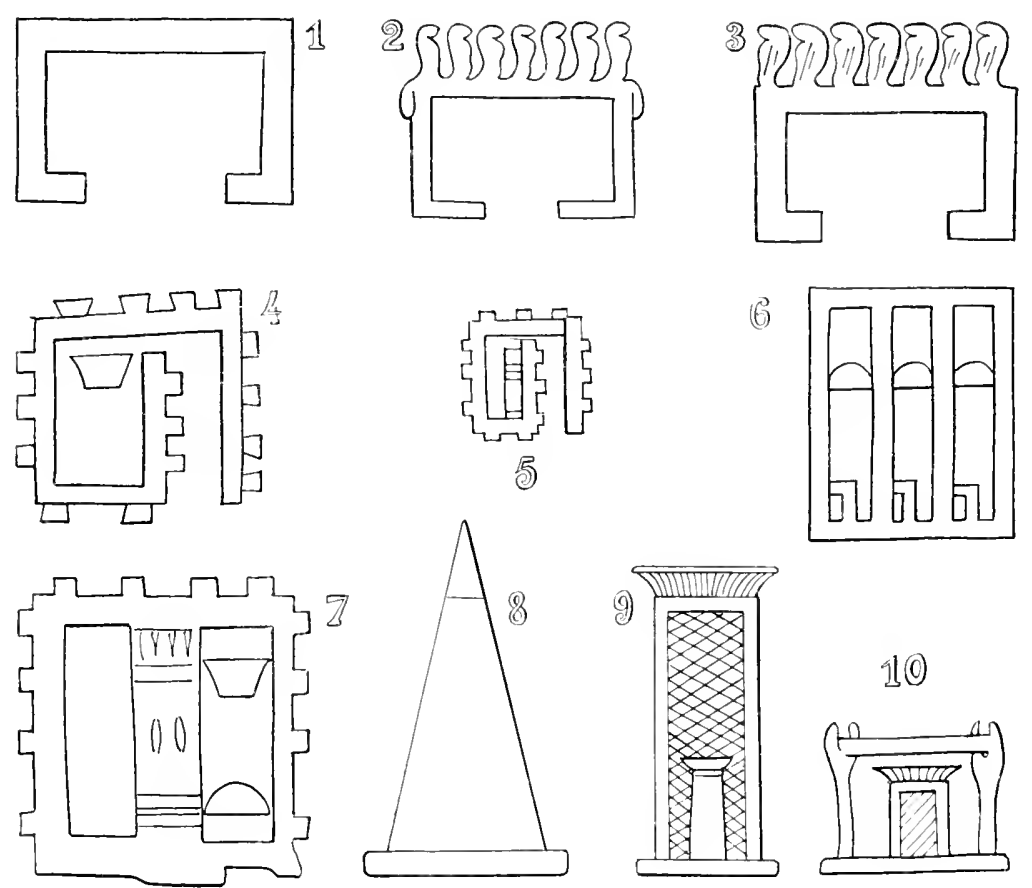

(G)
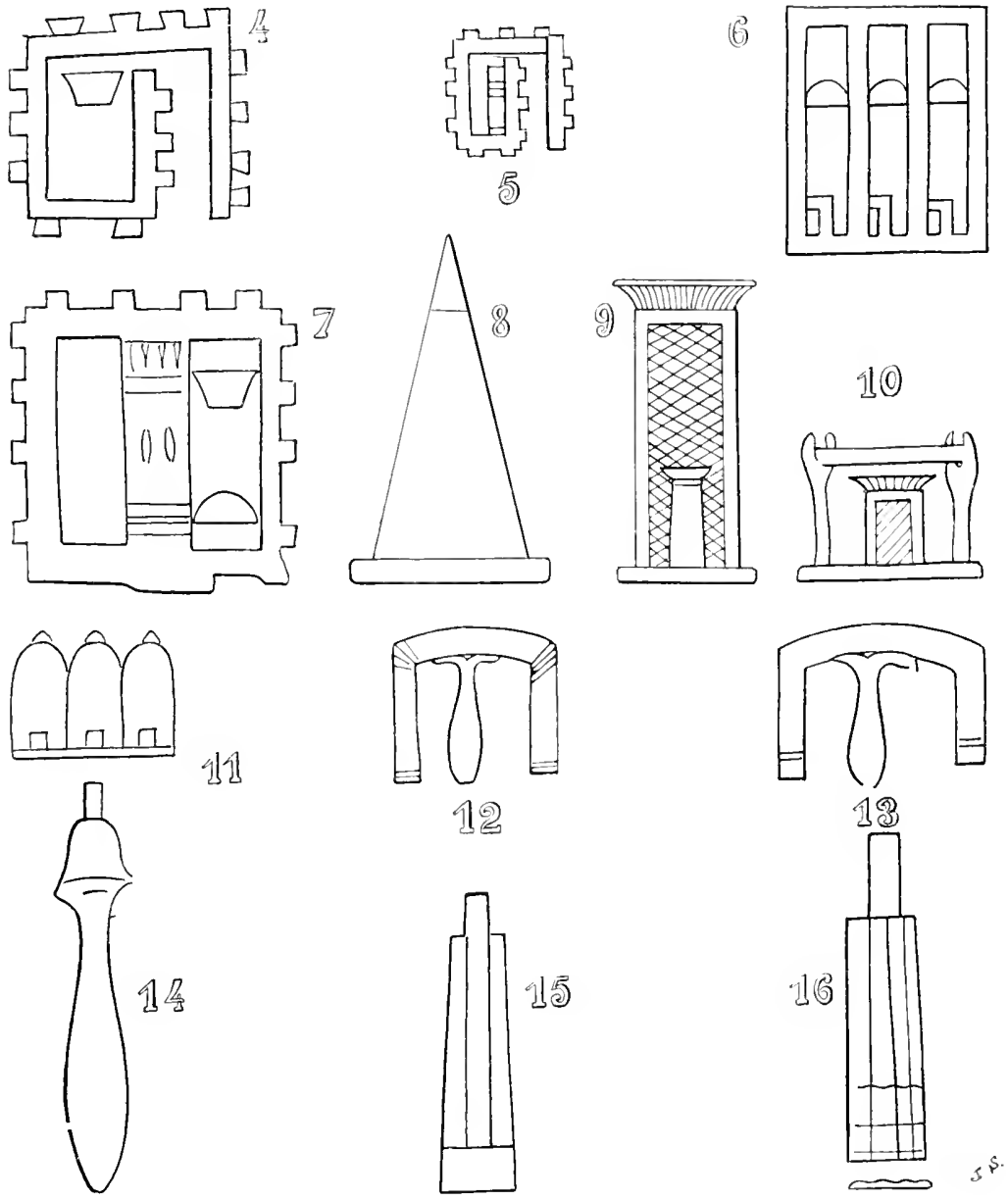


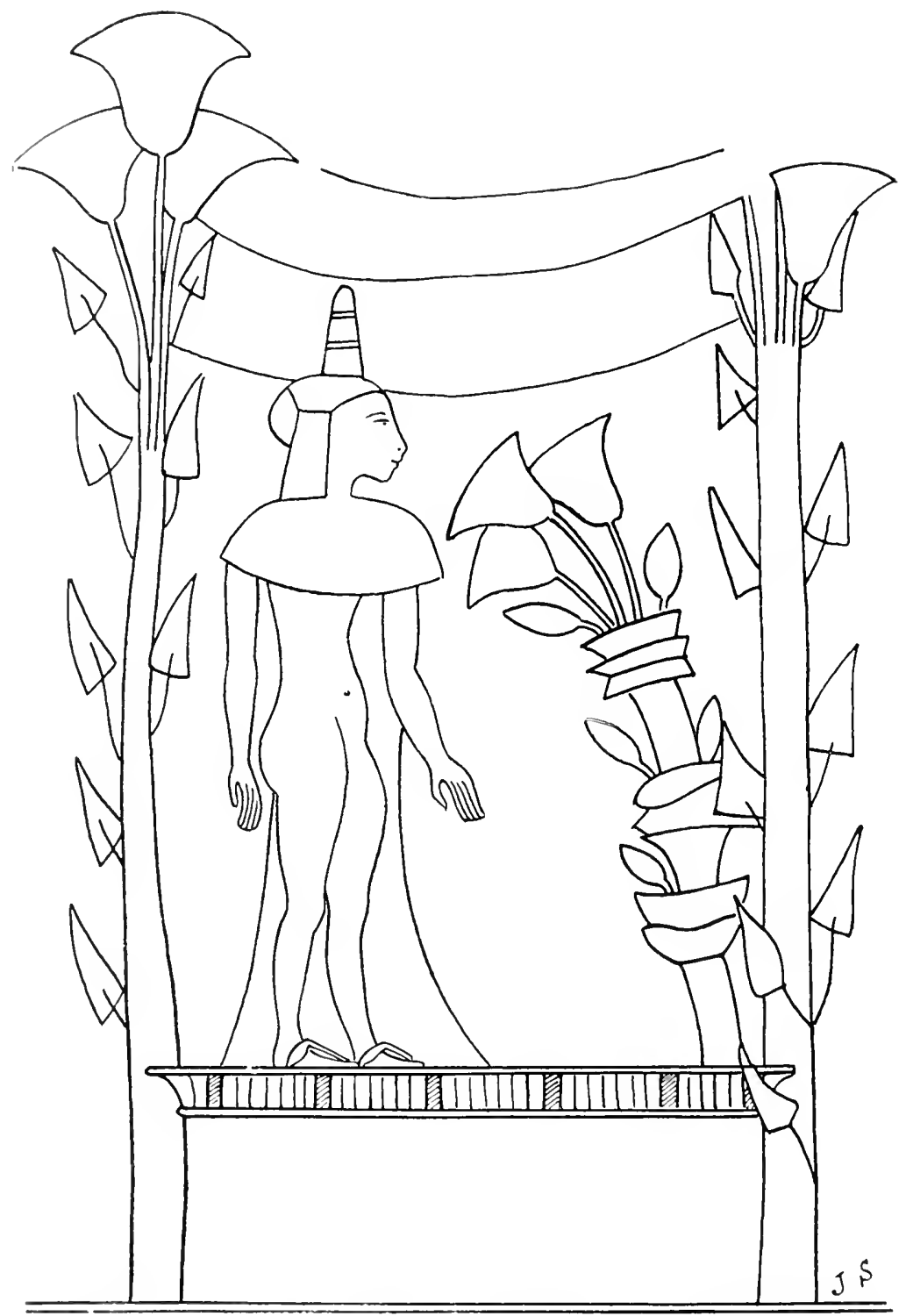

LIGHT CANOIP IN THE ROYAL TOMB AT TELL-EL-AMARNA 


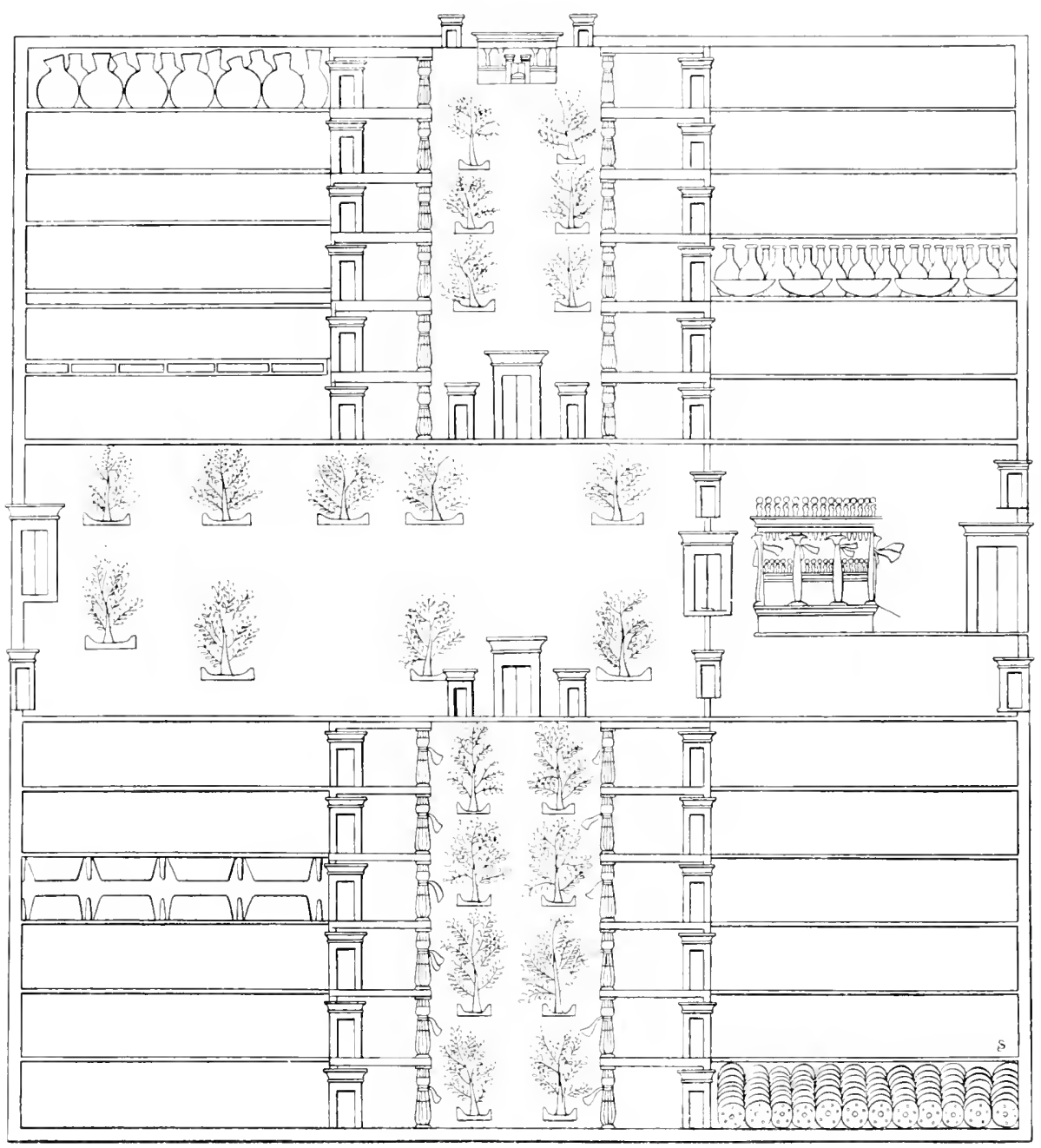

STOREHOUSES OF THE TEMPLE AT TELL-EL-AMARIA 


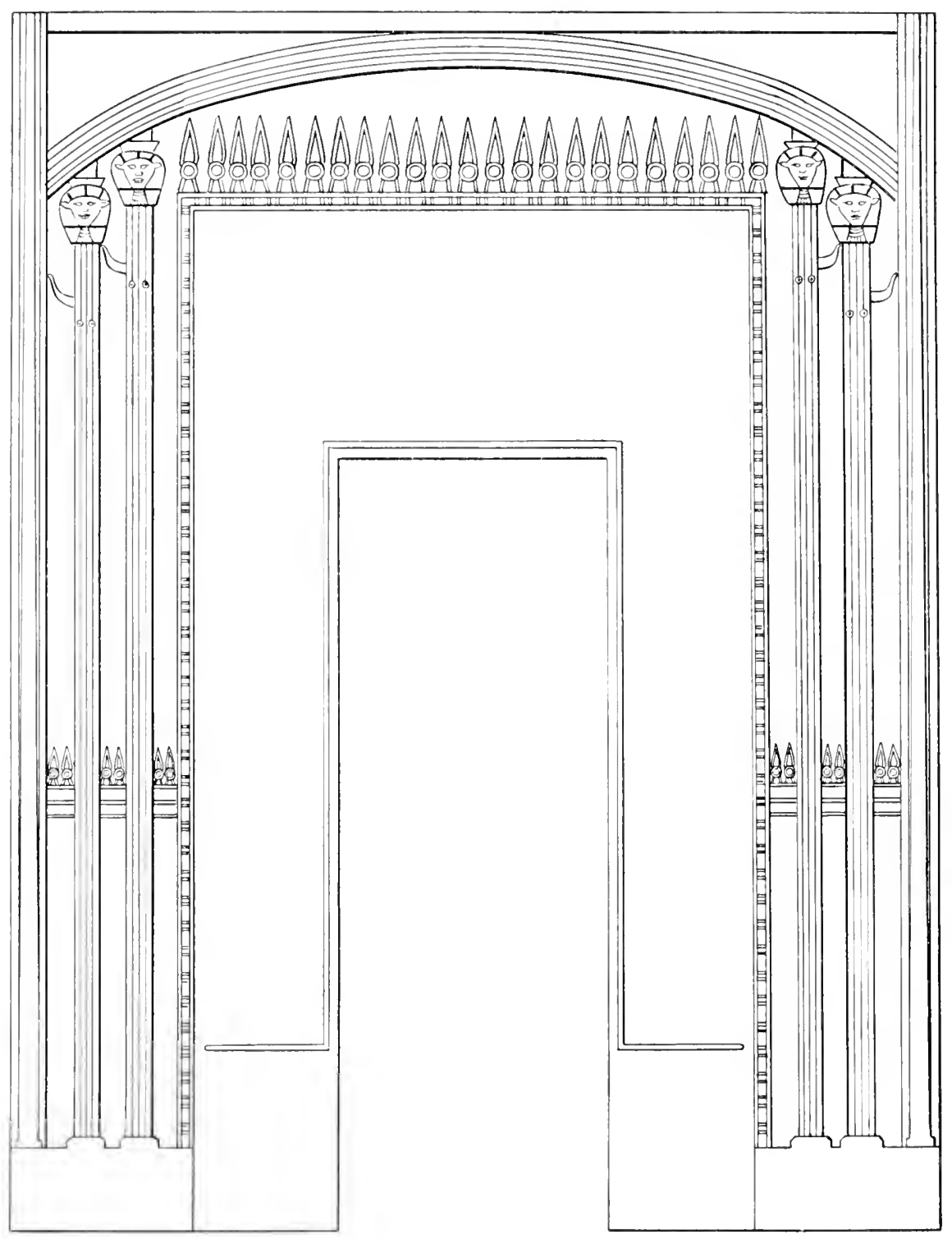


The tomb of Amenophis IV at Tell-el-Amarna presents a series of sculptures devoted to the death and funeral rites of a princess. We witness, amongst other things, a scene of lamentation which is enacted before the statue of the dead girl. (7) This latter is placed under a light canopy, composed of uprights supporting a skin or a mat.

This type of construction was not destined only to religious or funerary uses. In reality, in the cult of the gods and of the dead, the Egyptians merely borrowed from the usages of the living. They delighted, as a matter of fact, to erect in their gardens little pavilions, made of light materials, for recreation or rest. A tomb at Tell-el-Amarna (8) shows Amenophis IV attended by the queen and the princesses : the king is sitting under a kind of canopy with a double cornice, surmounted by a row of serpents. The two columns which serve as supports are of a very complicated type. From the lower edge of the cornice hang garlands of flowers. On the walls of the tomb of the high-priest Meryra at Tell-el-Amarna a garden is depicted in the form of a cross, dividing the storehouses of the temple into four groups. (9) In this garden is a pavilion of the same kind, supported this time by four little columns of a floral type, with a cornice surmounted by serpents. Furthermore, the columns are joined by a sort of balustrade or low wall also surmounted by a frieze of urai. It is probable that in the first case the two central columns and the wall between them were omitted in order to show more clearly the persons within. (IO) None of these kiosks, I may repeat, as fragile as they are graceful and elegant, have been preserved, but the Egyptians have bequeathed to us more massive copies of them in "everlasting" materials, such as the famous kiosk of the Island of Philæ.

The desire not to abandon the forms of these light constructions of joinery, which were in a sense sacred, has given rise to many curious arrangements in buildings erected with heavy materials, of which we may now cite one example. In the Hathor sanctuary at Deir-el-Bahari, built in the early XVIIIth dynasty, a façade, or rather a door-frame, carefully mimics a wooden construction. (I I) Even a cursory 
examination is enough to show that it is not appropriate to the position it occupies, and that its proportions are such as to justify the thought that it is rather the result of a conventional idea than a part of a well-thought-out architectural scheme. In the central part the door and its framing are surrounded by a border decoration, while the top is decked with a frieze the origin of which we shall study later on. This first part alone makes up a complete structure, which is placed entire under a roof upheld by columns. The columns, which are of polygonal type, are surmounted by heads of the goddess Hathor, to whom the sanctuary is dedicated. Curiously enough, near the tops of the pillars and on the pillars themselves are designed two bosses which recall breasts, as if the entire column were intended to represent the goddess. It will be observed also that horns are affixed to the pillars, and indeed the goddess Hathor is often depicted in the form of a cow. The drawing of the walls between the columns completes the whole, and shows that we must probably consider the construction as a chapel surrounded by a colonnade on which rests a roof : an arrangement frequently met with in the planning of the XVIIIth dynasty temples.

The most important of these architectural designs, rendered in relief upon a wall, is furnished by the stelæ of the tombs, especially those of the Ancient Empire, to which the second part of this chapter will be devoted.

In the tomb of Ptah-hetep I at Saqqara, one of the walls brings the two most frequent types together side by side. (I 2) It is only necessary to glance at the photographs to understand at once why one should be called an ornamented stele, and the other a simple, or ordinary, stele.

The ornamented stele (I 3 ) is characterised by a series of projecting pilasters with recessed niches, and by a series of battens and spaces which look like hatchwork. On either side the uprights enclose a central cavity, which we may, at least provisionally, call a door. Above this is a grating corresponding well to a window, doubtless intended to light the interior of the building.

One can scarcely fail to notice immediately the analogy 
which this ornamented stele presents with the decoration of the stele of the Serpent King, as well as with the arrangement of the outer walls of the royal tomb of Naqada. As a matter of fact the ornamented stele occurs, as we have already said, as a general theme, in a whole series of Egyptian documents.

Let us now take up the problem in fuller detail.

The sarcophagus discovered in the chamber of the pyramid of King Mycerinus (I4) is decorated entirely on its four faces with the motif of the ornamented stele; this is thrice repeated on each of the long sides and once on each of the short sides. Each face ends in a projecting ridge surmounted by the cornice. We could instance, perhaps, half a dozen sarcophagi of grandees of the Ancient Empire which display similar devices. Thus, on the sarcophagus of Khufu-Ankh in Cairo Museum, (15) whilst the two short sides show almost the same design as the coffin of Mycerinus, each of the long sides gives the motif of the stele once only, but on a broader scale. It must therefore be assumed that on the sarcophagus of Mycerinus we witness the use of architectural elements in a condensed form following the precedent which we saw in the case of the representation of the door in the shrines of the temple of Abydos.

The fact that sarcophagi are thus decorated on all four sides proves that we are dealing with a kind of imitation of a self-contained structure, and in fact the large monuments of the Ancient Empire display the same type applied on a considerable scale. The Shounet-ez-Zebib at Abydos, which some consider to be a fortress, but which is more probably a funerary monument, is a large enclosure built of bricks whose exterior walls show the arrangement of pilasters and niches. (I6) In the interior, the remains of a building have been discovered. The royal tomb of Naqada (I7) consists of a central nucleus, made up of a burial-chamber and four chambers which are the storerooms : once the dead had been laid to rest and the walls bricked up, a great retaining wall was set up, the outer surface of which again conforms to the arrangement we are dealing with. The free space between the central core 
and the retaining wall was later divided up by partition walls. As these abut upon the walled-up doorways, it is certain that the tomb, properly so called, was built first, before the walls were begun which enclose the whole.

A certain number of Ancient Empire tombs repeat the same series of pilasters and niches on all four faces, whilst in others its use is confined to one façade only, or even to part of a façade, preferably that into which opens the door leading to the chapel dedicated to the funerary cult. Whether the wall be of brickwork or stone, the arrangement remains the same. Where the walls are of bricks, these are covered over with a coating on which all the details are carefully painted.

The same architectural decoration extending over the whole wall-surface is sometimes found inside the monuments, as in the sepulchral chamber of the pyramid of Unas around the sarcophagus : (18) or again in the basement, as in the sanctuary of one of the Beni-Hasan tombs. (19) But more often only parts of it were represented, usually confined to one or two doorways and their framing. For the two doors it will suffice to go back to the monument which we already know so well - the stele of the Serpent King. We can now have no hesitation in identifying what the lower part of it represents.

Why did the builders confine themselves to two doors? or rather why were two made instead of one? In Egypt we frequently observe the repetition of two similar elements. It is thus that the kings had two tombs, and that it was a frequent practice to place two statues of the deceased in the tomb-chapel. The origin of this reduplication must evidently be sought in the customs of Egyptian royalty : there was not simply a kingdom of Egypt, but one kingdom of Upper Egypt and another of Lower Egypt, although both were united under one sceptre and ruled by one and the same person. "Pharaoh" in Egyptian really means " the great double house." Thus the whole administration is divided into two parts : even in the religious cult it was never neglected to represent the share of the two Egypts in offerings to the gods. It is therefore natural to set up 


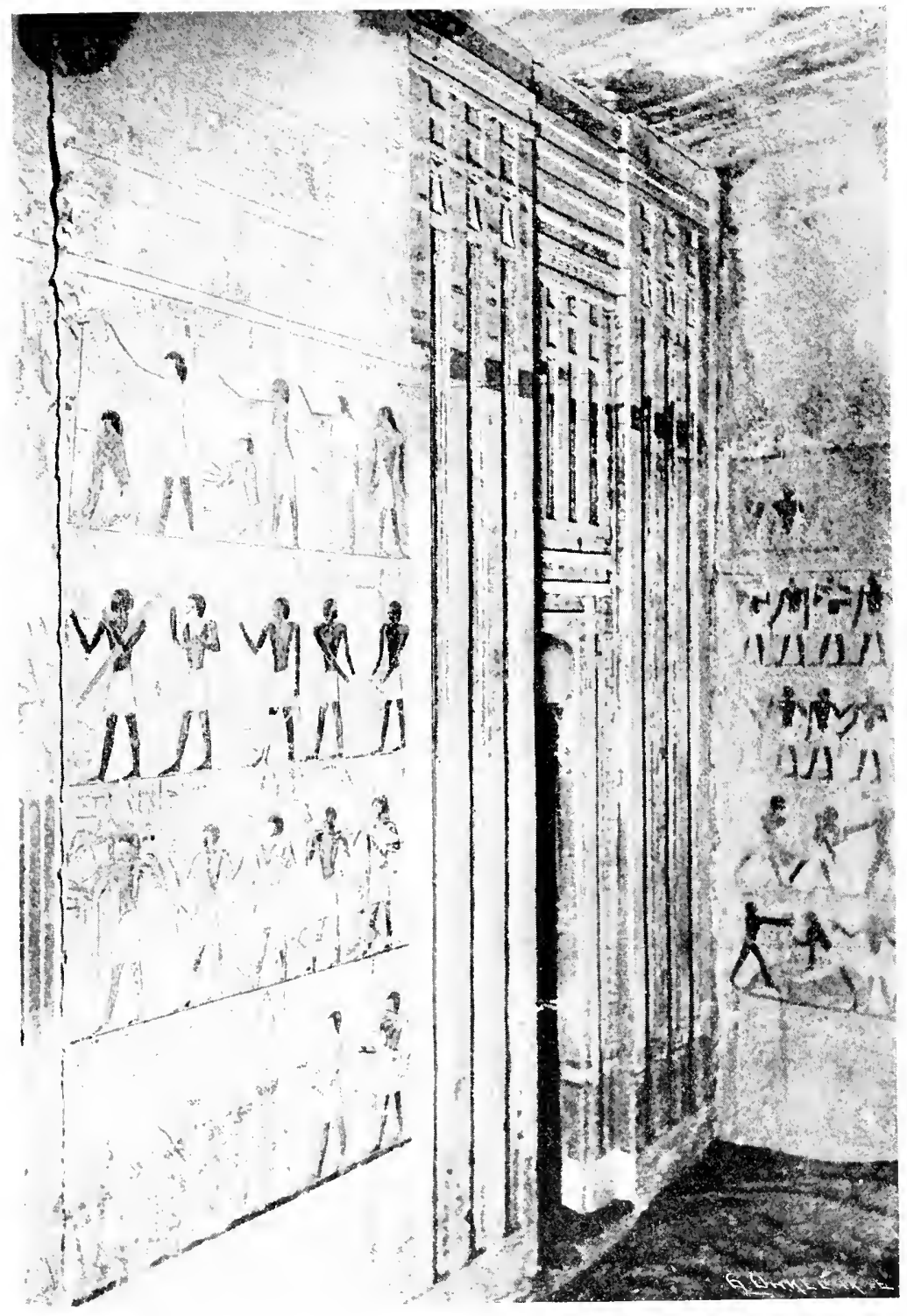




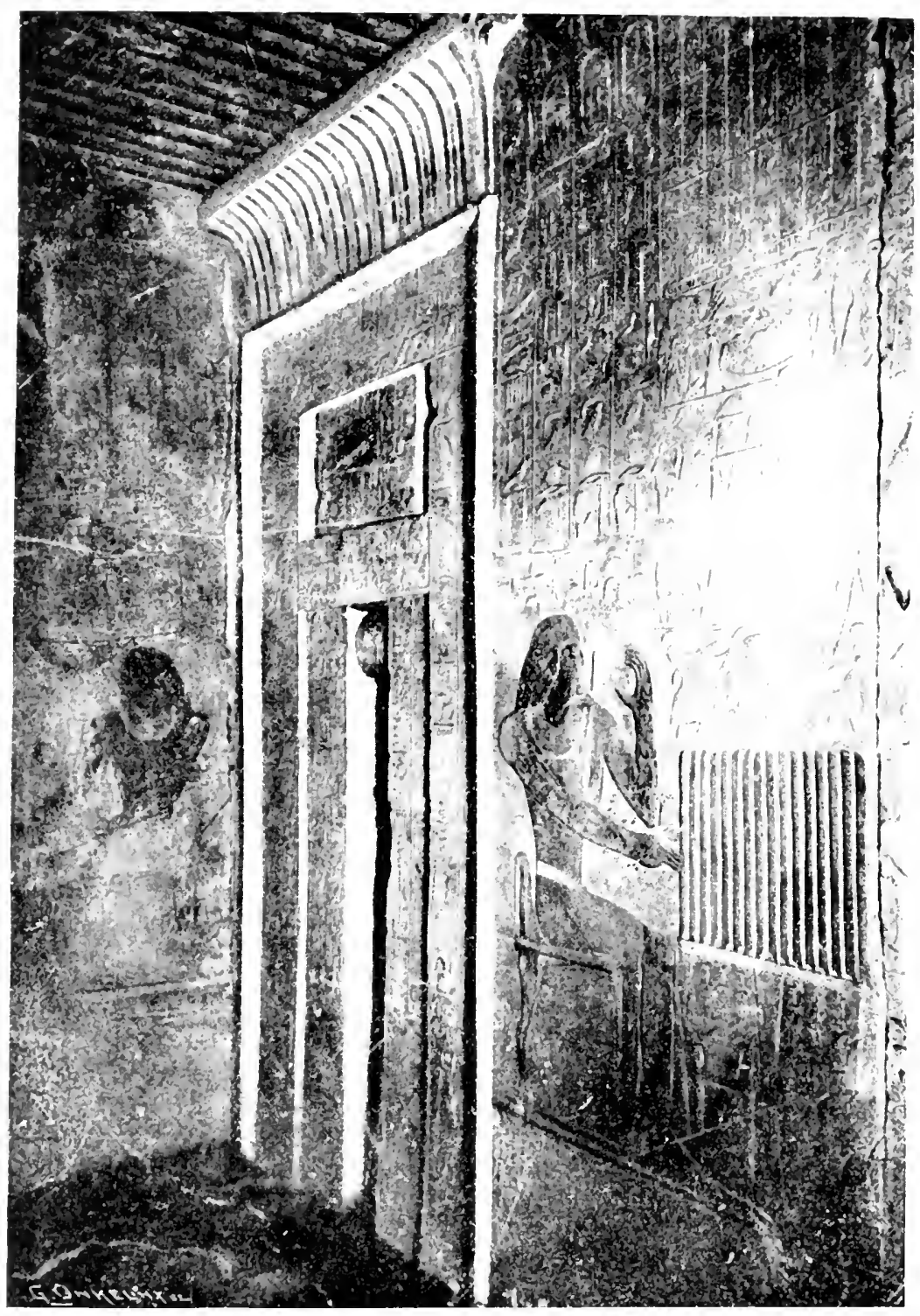




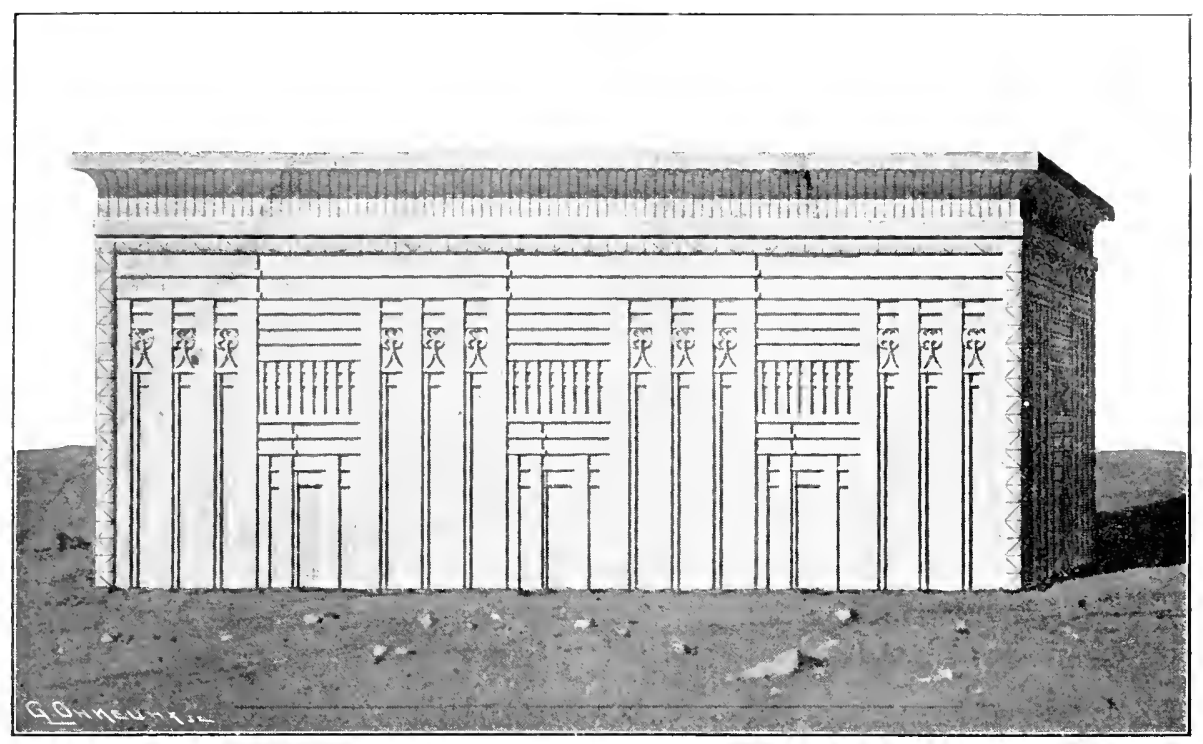

THE SARCOPHAGUS OF KING MYCERINUS 

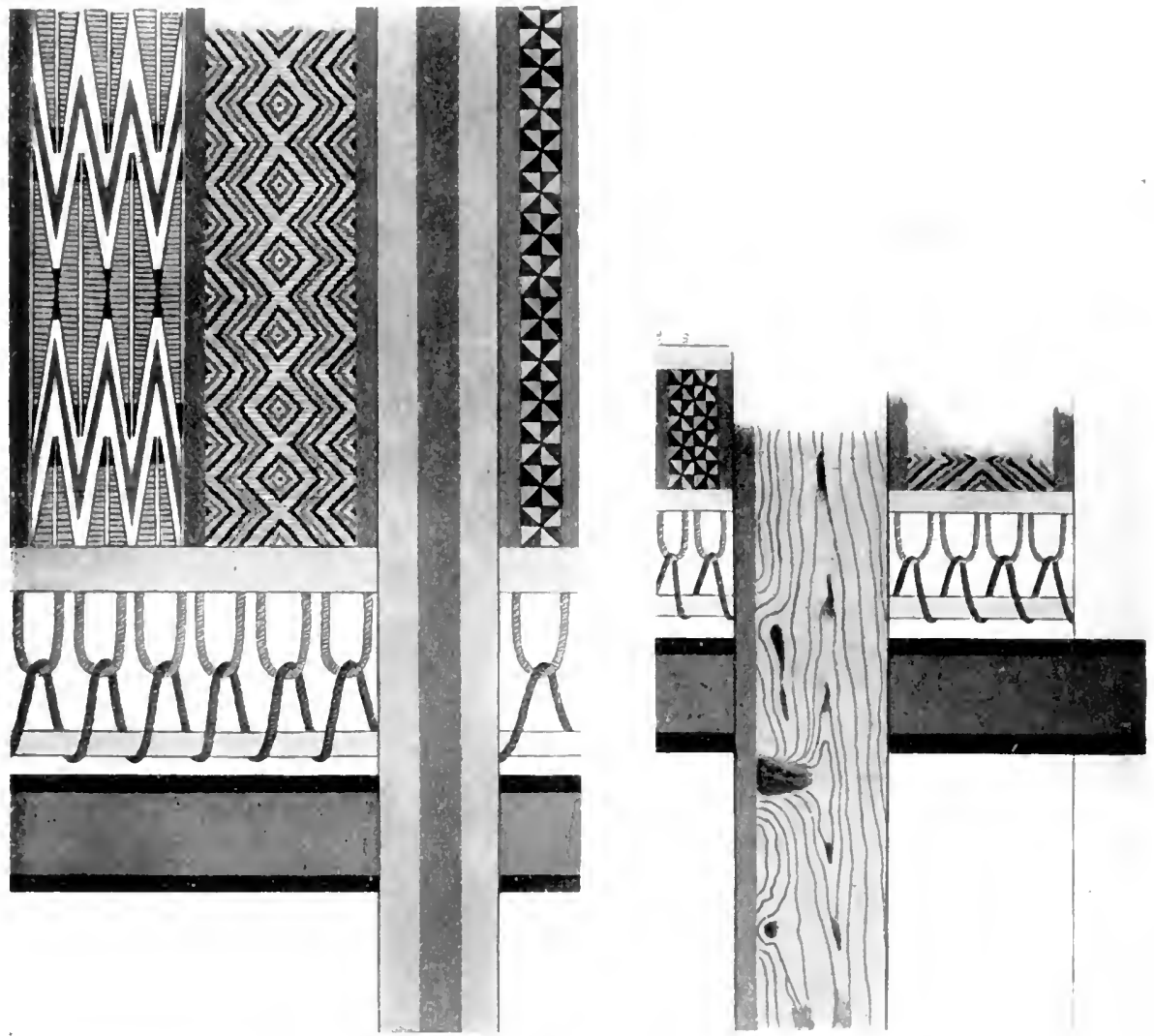
two ornamented stelæ in the royal monuments. For persons of high rank he same thing was done, in conformity with the rule which dominated all the Egyptian funerary rites. These latter actually began by being exclusively appropriated to the person of the sovereign ; little by little they passed to members of the royal family and to the high dignitaries before they were conceded to those who had deserved favour : finally, little by little they again passed on by "contagion" to the whole Egyptian nation. It is by virtue of this principle that in the tombs of Sabu or of Niankh-Re, (20) to mention only these instances, the end wall of the chapel is occupied by a double architectural decoration. It is through this, also, that in the tomb of a person known as Situ the two ornamented stelæ, now in Cairo Museum, (2 I) were found. The presence of a very characteristic motif is there detected, composed of two flowers combined as a sort of heraldic device, and which occurs everywhere on the monuments. It is set off by a framing, which makes an opening in which it stands out in relief. It will be observed also that in this example the central niche is closed by a door of which the upper and lower pivots have been carefully indicated.

But often the niche-motif is represented only once, as we have already seen in the mastaba of Ptah-hetep. The delineation of only one of the elements is equivalent, so it would seem, to the complete architectural representation. There might be, however, another explanation. That would be the belief that there really were constructions of this kind, of very varying dimensions, from a tomb which measures hundreds of yards in length down to chapels only a few feet across, but all nevertheless reproducing the same general forms, and such might well have been in conformity with Egyptian customs.

A single motif is sometimes repeated in several examples, one beside the other, which cannot fail to recall the great and complex monuments which we considered first of all, but such repetition need not imply absolute identity. Indeed, it is not so much a case of a continuous motif as of a simple motif multiplied indefinitely without at any time losing its 
individuality. We might quote as instances the Horus names on the containing wall of the temple of Sesostris I at Lisht, (22) or the decorated stelæ on the sides of certain Middle Empire coffins. (23)

We must now examine a detail which is characteristic of the whole of this series of representations-the door-posts, or rather such of them as are ornamented with paintings wherein imitation of matwork or of woven fabrics stretched on straps or bands has long been recognised. On the stele of Ptah-hetep, (24) one can clearly see the straps which pass through staples and are bound round a cross-piece to which the matwork or cloth is attached. On a stele from Abusir (25) the straps can be seen attached to small wooden cross-bars, which are affixed to the principal posts. These details, indicated by painting, show us, further, that we are really dealing with wooden erections made up of posts of different sizes, and fitted together in such a way as to make a kind of kiosk or verandah with open-work decoration.

Thus, on the main framework were stretched the matting or cloths which have just been alluded to, so as to shelter the inside from the sun or the wind. Wherever the tomb is built of bricks plastered with stucco, the painter has imitated with great care the grain and the knots of a piece of wood on the surface of the principal posts. (26) It is difficult to aver, as several authors would, that this niche-formation was originally derived from the use of brickwork.

A wooden coffin from the necropolis of Tarkan, datable to the Ist dynasty, furnishes an example which adds a most valuable detail. $(27)$ The panels in which the doors open are cross-tied with round cross-bars. The interior would thus appear as firmly shut in by a barrier upon which, at heights varying according to need, pieces of matting or cloth could be affixed But if the ornamented stele is without doubt a complete abridged representation of a building, the nature of the latter must be determined. Le Page Renouf (28) demonstrated long ago that the formulæ of the texts show a strict relationship between the sereh-which 
is the name of the ornamented stele-and various words signifying "seat" or "throne." Moreover, I think I can recognise in the constructions we are discussing the royal Throne-Room, which may perhaps be compared with the apadana of the Persians. The appearance of this architectural type in the tomb-pictures bears witness to the spread of royal funerary rites to more and more extensive classes of the Egyptian population.

We now pass on to examine the simple and ordinary stele, and we will begin by comparing it with the ornamented stele. The wall of the tomb of Ptah-hetep shows them side by side, a clear indication that one must be considered as the variant of the other. In the Ancient Empire tombs two simple stelæ are found in place of the two varieties in the tomb of Ptah-hetep. We shall discern the same fundamental elements in both types: the central door framed by the jambs. Above the door, in the ornamented stele there is a window of straight grooves : in the simple stele there is a central decorated panel, but on either side of it is a groove. There are besides intermediate types, where on a simple stele we find, for example, on the right and left of the door an upright with a floral decoration in open-work, (29) or again, on each side of the upper panel a decorated device. (30) Accordingly we can have no hesitation in saying that the two stelæ are but one and the same idea, but with variations in decoration; both are copies of buildings.

The simple stele is probably the shrine which contained the statue. Let us then consult the tomb-reliefs of the Ancient Empire which throw light upon this point. In the mastaba at Leyden we witness the transport of the statue to the tomb. (3I) It is placed upright in a sort of large cupboard, the door of which, in two leaves, is wide open. On the upper part is the usual cornice. The shrine is drawn upon a sledge by oxen, and a priest burns incense before the effigy of the dead. To cross the water, the shrine is placed upon a boat, and this time its doors are shut.

The shrine in question will immediately be recognised in the tomb of Ay at Tell-el-Amarna, (32) where the 
innermost chamber, which contains the statue of the deceased, is preceded by a door the general aspect of which reproduces the form of naos of the Ancient Empire. The tomb of Rames, also at Tell-el-Amarna, (33) gives a variant which is frequent elsewhere, but very instructive. Here the chamber hewn out of the mountain and reserved for the statue has been dispensed with. The group of the deceased and his wife has been sculptured in the rock and framed by a doorway. We can scarcely interpret otherwise the simple stelix of the Ancient Empire, where we see a statue of the dead in relief in the central niche. Thus we may examine, for instance, the stele of Itti-Ankhars in the Cairo Museum. (34) Could one hesitate to designate it as the representation of the shrine containing the deceased's statue, simply because the construction which frames it is rather more complicated? In the stele of Ankhars, the door of the shrine is open and the statue visible, whilst in the stele of Nefer-hetep-s, for example, in the tomb of $\mathrm{Ti},(35)$ the two leaves of the door are shut.

In the ornamented stele the same relation is to be found in the structure with closed and with open doors. Most often, as we have seen, the two leaves of the door are shut, and the details of the bolts are represented by painting. In one tomb, that of Hesi at Saqqara, on the back of each of the niches a wooden panel was placed, each of which bore a figure of the deceased. (36)

The Egyptian texts generally designate the stelæ by the word "rut" or " ruti," generally translated " door" or "double door," and the determinative of the word is sometimes a copy of the characteristic form of the ordinary stele. In one case, in the tomb of $\mathrm{Ti}$ (Corridor I, east wall) (37), the same design determines the word "ro-per," which properly means "temple." Here we have a confirmation of the view we have just expressed, according to which the stele has not only the value of a façade or a door, as is often held, but a complete building of which only the façade is represented.

The simple stele is a naos of religious origin, and the ornamented stele shows the administration to the dead of 
royal rites which bears witness to the identification of the dead with the god.

We must now finally examine a third type, which is akin to the two first. This time, a building is still concerned, but one whose open-work sides show a greater complexity in the details of the carved devices.

We will begin by considering three representations of funerary constructions which are designed on the sarcophagus of Kauit, which comes from an XIth dynasty tomb at Deirel-Bahari. (38) The first is a rectangular construction manifestly closely allied to the ornamented stelæ, and surmounted by a cornice. The second represents on its lower portion two large niches or doors, surmounted by a panel divided into several sections and filled with carvings imitating the forms or hieroglyphs or amulets. The third would seem to be viewed from the side, judging by the curvature of the upper part, and on the whole somewhat resembles the second specimen. Its lower part is divided in the same manner, whilst the open-work decoration, instead of being enclosed in a rectangle, is bounded above by a curved line. It will be further observed that this third construction would seem to be standing upon two feet. It is then a kind of large cupboard or shrine in which the statue of Princess Kauit could be enclosed.

It fortunately so happens that in the XIth dynasty temple at Deir-el-Bahari we have a copy in stone of the funerary shrine of the princesses whose vaults were discovered in the precincts of the temple. The study of the restorations, so carefully made by Madame Naville, is extremely instructive. It would seem that probably the representation of the third shrine, on the sarcophagus of Kauit, gives us a view of the original piece of furniture made of wood, of which the two others are the counterparts wrought in stone: one picture would render the front view, the other would show the lateral view. Now if we look at the façade of the shrine of Princess Sadhe, (39) we shall clearly identify the general forms of the first shrine. On the lateral face of that of Aashait (40) we shall recognise the outlines of the second shrine, but with the difference that the circular form 
on the upper part of the open-work decoration has been kept. The painting of the fragments is again evidence as to the imitation of woodwork. All the texture of wood has been carefully reproduced on the surface of the stone. (4I) The same care has been taken to vary the appearance of the openwork decoration, marking the general framework as of one kind of wood, and showing by different tints the use of substances of various colours for the open-work ornamentation. (42) Ivory also enters into the composition of these decorations, where we find as the principal devices falcon heads, "dad "-amulets, little polygonal columns, and finally the floral designs to which we drew attention on the ornamented stelæ.

Similar constructions occur from time to time amongst the monuments of later periods : such is the stele which occupies the central position on the end wall of the sanctuary of the temple of Seti I at Abydos. (43) Prisse copied from the monuments of the New Empire constructions, which are analogous in all respects. (44) One tomb at Tell-elAmarna, that of Tutu, (45) gives one more very instructive example copied in stone. This time it is a case of a niche at the back of which was placed a statue of the deceased, which specifies, if it were still necessary, the purpose of the shrine.

In addition, we may in conclusion compare two paintings from the Theban tombs. One shows a wall occupied by a niche, hewn out to contain the statue, and which, upon its upper portion, is painted in imitation of lattice-work. (46) On each side persons advance towards it bearing funerary offerings. We may compare this arrangement with that of one of the walls in the tomb of Nakht: (47) it will be observed that the general manipulation of the design is identical. But here the niche with its upper decoration in open-work is replaced by a simple stele, such as was customary under the Ancient Empire, and which we have analysed above. This last comparison proves the identity in the function of the three types-decorated stelæ, ordinary stelæ, and open-work chapels. All three are really funerary shrines in which the cult-statues were placed, and it were better 
not to speak of them any more as stelæ in the form of false doors, destined exclusively for the use of the soul. One may search in vain in the texts for any passage which would confirm this interpretation.

\section{BIBLIOGRAPHY.}

I. In Davies, N. de G., The Mastaba of Ptahhetep and Akhethetep, Part I, London, I900, pl. XII.

2. Bénédite, G., La Stèle dite du Roi Serpent, in the Monuments Piot, t. xii., 1905 , pl. I.

3. Capart, J., Le Temple de Séti Ier, Brussels, I9I2, pl. XX.

4. Ibid., pl. XXV.

5. Davies, N. de G., The Rock Tombs of Sheikh Saïd, London, r 9or, pl. XV.

6. Puchstein, O., Die Ionische Säule, Leipzig, 1907, figs. 22-4.

7. Bouriant, U., G. Legrain and G. Jéquier, Monuments pour servir à l'Étude du Culte d'Atoncu en Egypte, t. I., Cairo, I903, pl. X.

8. Davies, N. de G., The Rock Tombs of El Amarna, Part II, London, I905, pl. XXXII.

9. Ibid., Part I, London, I903, pl. XXXI.

10. Compare the same pavilion with four or five columns, ibid., Part III, London, I905, pl. XIV (empty), and Part II, pl. XXXVII (occupied by the royal family). pl. CIII.

I I. Naville, E., The Temple of Deir-el-Bahari, Part IV, London, Igor,

I 2. Davies, N. de G., The Mastaba of Ptahketep and Akhethetep, Part I, London, I900, pl. II, and the photographs of pl. XXIX.

I3. Ibid., pl. XIX.

I4. Maspero, G., The Dawon of Civilization, London, I 896, p. 377.

15. Grébaut, E., and G. Maspero, Le Musée Egyptien, t. i., Cairo, I890I900, pl. XXI.

16. Ayrton, E. R., C. T. Currelly and A. E. P. Weigall, Abydos, Part III, 1904, London, r 904, pl. VI.

17. Borchardt, L., Das Grab des Menes, in the Zeilschrift für äegyptische Sprache, t. xxvi., I 898 , pl. XIV-XV.

18. Maspero, G., The Dawn of Civilization, London, I910, p. 437.

19. Newberry, P. E., Beni-Hasan, Part I, London, I893, pl. XXXVI.

20. Mariette, A., Voyage dans la Haute Egypte, Cairo, I 878, t. i., pl. 5 and 8.

21. Maspero, G., Guide du Visiteur au Musée du Caire, 191 5, 4th edition, fig. 7 , p. 20.

22. Gautier, J. E., and G. Jéquier, Ménoire sur les Fouilles de Licht, Cairo, 1902, p. I 2.

23. Lacau, P., Sarcophages antérieurs au Nouvel Empire, Cairo, 1905, pl. XIIII.

24. Davies, N. de G., The Mastaba of Ptahhetep and Akhethetep, Part I, London, ig00, pl. XX. 
25. Borchardt, L., Das Grabdenkmal des Königs Ne-User-Ré, Leipzig, I907, pl. 24.

26. Quibell, J. E., The Tomb of Hesy, Cairo, I913, pl. VIII.

27. Petrie, W. M. F., Tarkan I and Memphis V, London, I 91 3, pl. XXVIII.

28. The Horus Standard and the Seat of Horus, in the Proceedings of the Society of Biblical Archeology, t. xiv., I891-92, pp. 17-22. Reprinted in The Life Work of Sir Peter Le Page Renouf, t. ii, pp. 435-40.

29. Lepsius, R., Denkmäler, I, pl. 4I. Tomb I5.

30. Mastaba of Neferartnef at Brussels.

31. Boeser, P. A. A., Beschryving van de Egyptische Verzameling, t. i., Leiden, 1905, pl. IX.

32. Davies, N. de G., The Rock Tombs of El Amarna, Part V, London, I 908 , pl. XX.

33. Ibid., Part IV., London, 1906, pl. XLV.

34. Murray, M. A., Sagqara Mastabas, I, London, I905, pls. XIX and XXXV.

Maspero, G., Guide du Visiteur au Muske du Caire, 4th edition, I9I5, fig. 5 , p. 18.

35. Steindorff, G., Das Grab des Ti, Leipzig, I9I3, pl. 45.

36. Quibell, J. E., The Tomb of Hesy, Cairo, 1913, pl. V.

37. Steindorff, G., Das Grab des Ti, Leipzig, I913, pl. 3 I.

38. Naville, E., and H. R. Hall, The XIth Dynasty Temple at Deir-elBahari, Part I, London, 1907, pl. XX.

39. Naville, E., The XIth Dynasty Temple at Deir-el-Bahari, Part II, London, I9ro, pl. XI.

40. Ibid., pl. XIV.

4I. Ibid., pl. XIII.

42. Ibid., pls. XV. and XIX.

43. Capart, Jean, Le Temple de Seti Ier, Brussels, I 9 I 2, pls. XVI and XVII.

44. Prisse d'Avennes, Histoire de l'Art égyptien, Paris, I 878, t. i., pl. I 2.

45. Davies, N. de G., The Rock Tombs of El Amarna, Part VI, London, 1908, pls. XXXVI and XII.

46. Tomb of Menna. Maspero, G., The Struggle of the Nations, 2nd edition, London, I910, p. 519.

47. Davies, N. de G., The Tomb of Nakht at Thebes, New York, 1917, pls. VIII and IX. 


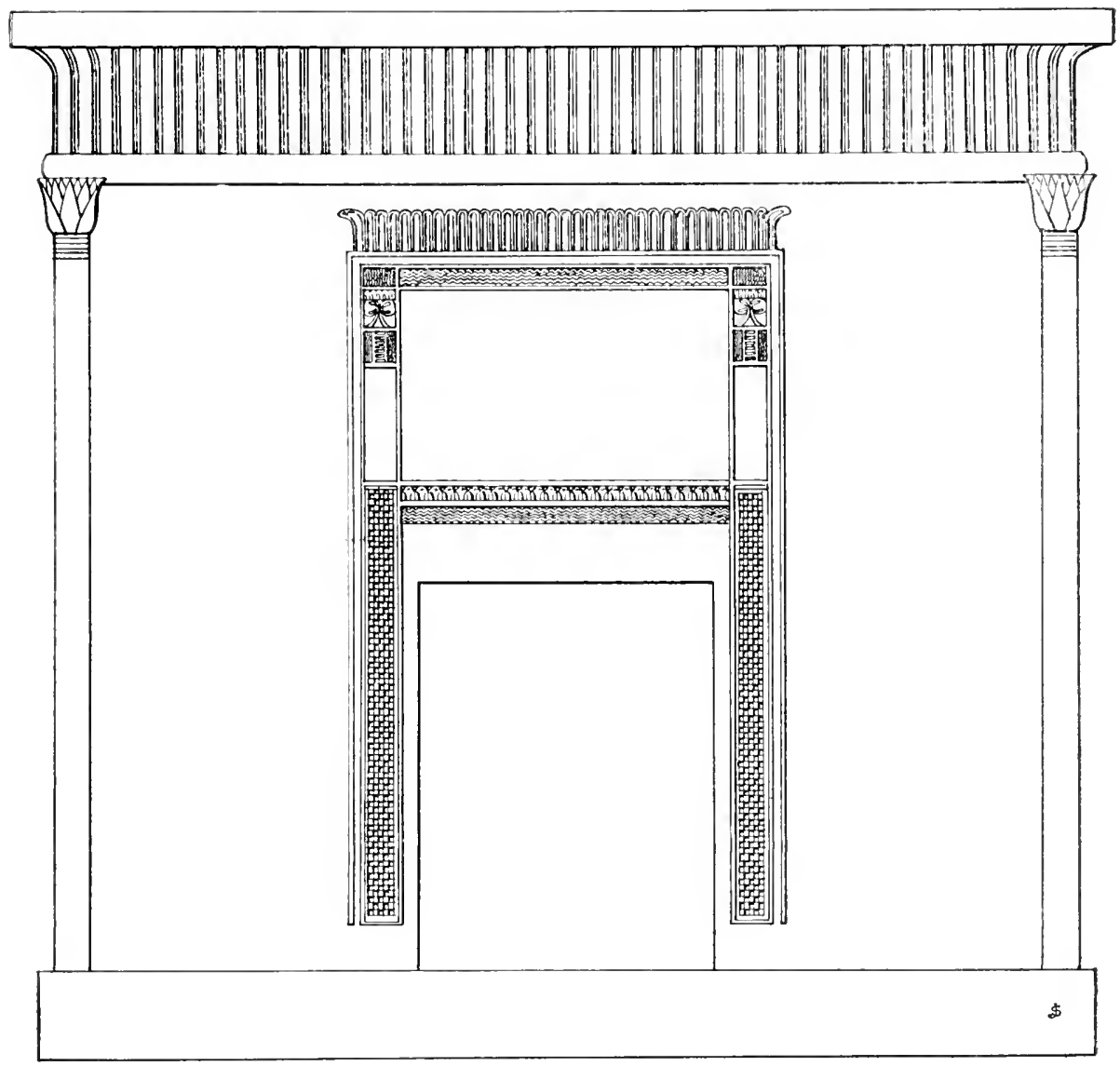




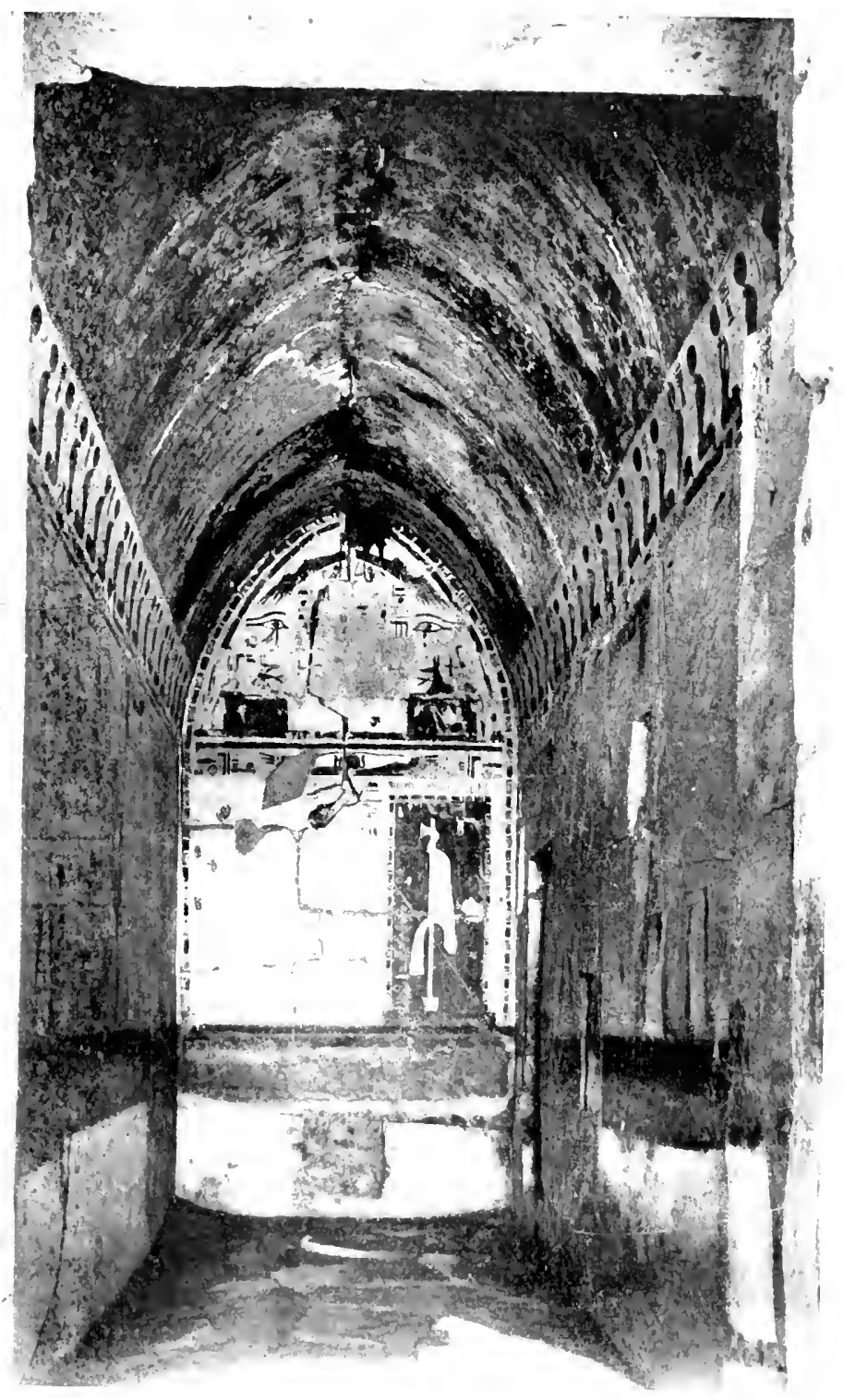

CIIALL OF INIBIS AT DEIR-LL-BAHARI

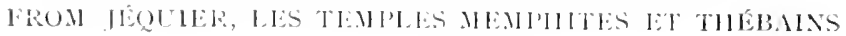




\section{MATERIALS AND ELEMENTS OF BUILDING}

HE Egyptians used clay extensively not only in the industrial arts, such as pottery, but also for building.

1 It was used principally as daub or as bricks.

Mud.-It would seem that mud-building is the most ancient type, for one can trace its technical forms copied in other types: thus, according to most authorities, the Egyptian gorge ${ }^{1}$ owes its origin to the incurvation produced by the pressure of the roof upon a building made of mud. The mud is applied to a framework of palm-branches, the tops of which, standing out free, are pushed outwards by the beams which form the roof. The torus, in the form of a fillet, was originally a kind of straw padding placed at the angles of the building to strengthen them. (I)

Little models of dwellings are often found, especially in the tombs of the Middle Empire, and these reproduce the forms of the mud-built houses such as are made to this day by the natives of Egypt. (2)

Granaries, which were cylindrical buildings capped by a little dome, figure among the hieroglyphs. Granaries of this type are shown, for example, in a painted representation of the house of Anena, at Thebes. (3) The enclosing wall is bounded on its upper surface by an undulating line, which certainly indicates mud, for if the wall were of brick, battlements would have been traced by an angular line. Beyond, first the rectangular house of worked materials is seen, and

I I am obliged to retain the word gorge, as we have no English equivalent which expresses the special meaning here implied. The characteristic form of Egyptian buildings is produced by sides which slant slightly inwards, and at the narrowest point-the gorgp-is a ridge above which the comice spreads outwards.-TransLator. 
then the two granaries and a large building with a bulging roof, which served perhaps as a storehouse. These three last buildings, as well as the containing wall, seem clearly to be designated as of mudwork.

Bricks.-The brick makes an early appearance in the Egyptian tombs. From the time of the Ist dynasty its use becomes quite customary. Egyptian brick is made of mud mixed with sand and straw, then worked into elongated blocks and hardened by the sun. A picture in the tomb of Rekhmara at Thebes shows a brickworks in full activity. (4) Workmen are bringing the mud from a pool or a marsh, turning it out in heaps upon the ground, working it up with a hoe, then moulding the bricks, which are laid out in straight lines. When they are dry, a labourer carries them to the place where building operations are in progress.

The dimensions vary according to the period: one might say, as a general rule, that the brick increased in size from the Vth to the XVIIth dynasties, and decreased perceptibly from the XXIst onwards. (5) The oldest specimens of baked bricks go back only to the XXIInd dynasty. Bricks are frequently found bearing a mark or inscription stamped upon them. More rarely bricks contain foundation tablets of stone or enamelled earthenware, upon which are inscribed the name of the king who erected the building, the indication of the edifice in which they were used, or the name of a functionary. (6)

Bricks are laid either in horizontal courses or in incurved courses : this curving of the courses has sometimes been accounted for by the slackening of the string which served as a guiding-line for the masons. This explanation, however, is contradicted by the presence of courses in which the curving is inverted. Some great walls actually show bays in which the incurvation is alternately upwards and downwards. Choisy said that "the object of these undulations is to prevent the mass from sliding on the ground and the courses upon one another." (7) Petrie considers that this arrangement in curved courses might have given rise to the custom of building certain walls at a slope.

Leaving aside the pilastered walls of the ancient tombs, 
which we have already explained, it may be said that walls were generally uniform without any sort of special decoration arising out of the use of the materials. One brick building of late period, however, reproduced by Prisse d'Avennes, (8) has its outer walls ornamented by a system of niches similar to those which we have considered in the ancient monuments.

Sometimes between the courses of bricks the presence of layers of palm-leaves or matting is observed, evidently intended to drain the crude brick masonry. (9)

From the earliest times the Egyptians knew the use of brick vaulting. The vaulting attaches to two fundamental types : corbelled vaulting and semicircular vaulting. An archaic tomb at Naga-ed-Derr (Io) furnishes an excellent example of the first type : the bricks jut slightly one above another to the point at which they meet at the top, the addition of courses of brickwork above this arching imparting a certain solidarity to the whole. It would be difficult to trace how this type passed into the semicircular, which became quite a common custom, certainly from the IIIrd dynasty. At Meidûm (I I) semicircular work is combined with corbelling: the first layers of the masonry are laid on the corbel principle, and the free space is then filled in with bricks making a series of keystones.

In one of the plates in Garstang's book on the IIIrd dynasty are collected several very characteristic specimens of brick archings. (12) In one case it can be seen how several large blocks of mud placed in a polygonal position support a range of brickwork which marks out a regular vault. Is this one of the stages leading towards the invention of semicircular vaulting?

If the vaulting of these tombs strikes us as tentative or clumsy, one can scarcely say the same of the admirable work in the tomb of Adu I at Dendereh, which dates from the VIth dynasty. (I 3) An archway composed of three layers of bricks upholds without yielding the weight of a considerable mass of masonry.

It would seem that arch-formation was used by the ancients as extensively as it is by Arab builders of modern 
Egypt. It is met with under various forms in the storehouses of the Ramesseum at Thebes. (I 4)

We shall observe later on that the Egyptians often copied this form of vaulting in their stone buildings; which is not to say-be it noted-that they made stone vaulting. Sometimes the copy displays a perfectly semicircular vault; (I 5) sometimes, on the contrary, it is akin to the pointed arch, or ogee, as for instance in the chapel of Thutmosis I at Deir-el-Bahari; in the Anubis chapel of the same temple the copy is of a true ogee. (I6) In other cases the ceilings of chambers hewn in the rock copy elliptical vaulting; for example, in the tomb of Ramesses IV at Thebes, or again in the sanctuary of the temple of Es-Sebua in Nubia of the time of Ramesses II, where the curve of the vault is completely flattened. (I 7) The oldest vaulting is probably to be found in one of the Ethiopian chapels at Medinet-Habu. (I 8)

In the time of the New Empire, square spaces covered by a brick cupola are found. M. Piéron (19) has described a curious tomb with a cupola upon penditives, at Thebes, which he places between the XVIIth and XXth dynasties; at Abydos a brick tomb of the XXVIth dynasty is likewise surmounted by a cupola. (20)

Bricks were generally covered with coating, or painted plastering. Excavations at the Ist dynasty sites have brought to light quantities of glazed bricks which made the outer covering. (21) On the backs of some are tenons or slots by which they were affixed to the wall or attached to one another, perhaps by means of wires. The visible surface of these bricks is plain, or ornamented in imitation of the pattern of matting. The inner chamber of a pyramid of the beginning of the IIIrd dynasty was entirely covered with similar decoration. (22)

Wood.-Egypt grows but few kinds of wood which are usable for building. It is therefore not surprising to observe that the Egyptian texts have handed down to us accounts of expeditions sent out, principally to Syria, in order to procure wood for joinery. The papyrus of Unamunu is the most celebrated of the stories of this kind. 
It is, however, more surprising to note that these expeditions were made from the Ancient Empire onwards. Professor Sethe has proved that certain boats of this far-off period owe their specific names to the intercourse which Egypt maintained with the Syrian coast.

Wood was used, as we have seen, amongst other things for the construction of light kiosks or more or less complicated structures in joinery. It would seem that wood was likewise employed for panelling. A IVth dynasty tomb-that of Prince Merab, (23) a contemporary of Cheops-shows on the top of the dado, above which are arranged representations, a veritable panelling made of boards, the painting of which carefully picks out the grain ng. One might even ask whether we are not justified in thinking, on the authority of this example, that the yellow band so often painted on the walls of the Ancient Empire tombs might be an imitation of a wooden post let into the brickwork of the walls.

Rare woods were employed by the Egyptians in furniture, especially in inlay-work. We might here recall the open-work devices in the constructions which we studied in the previous chapter.

Finally, wood is often used in sculpture, and the texts mention statues made of different varieties of wood. The pictures which show the Southern races carrying tribute frequently display the bringing of logs of ebony.

Stone.-Stone occurs abundantly in Egypt and in the neighbouring desert: the quarries, which were worked from very early times, afford numerous varieties of limestone, sandstone, and granite. At Tura and Masara limestone was worked: at Hatnub (Tell-el-Amarna) was a rich deposit of alabaster. At Gebel-el-Ahmar is found red sandstone; at Silsileh, ordinary sandstone; at Syene or Assuan, several varieties of granite. In the Delta, in the Kankah region, a belt of basalt appears. In the Arabian desert a whole series of hard stones occurs, amongst others diorite and what the Egyptians called "Bekhen stone," which is a black gritty schist.

Egyptian sculptors made use of all these materials, and 
did not shrink from attacking the very hardest stones, even obsidian, quartz and petrified wood.

The inscriptions left by the Egyptians in the quarries furnish valuable data. The minister, Uni, narrates in his tomb inscription a memorable expedition to the Assuan quarries under the VIth dynasty.

M. Montet has re-edited and carefully studied the inscriptions of the Hammamat valley, (24) called by the Egyptians Rohanu, and which connects the Nile Valley with the Red Sea, above Koptos and Koseir. The following interesting facts are borrowed from this author: Six expeditions to the valley took place under the reign of Darius from his twenty-sixth to thirtieth years; three expeditions under Amenemhat III (XIIth dynasty); only two under Sesostris III ; and two again under Ramesses IV (XXth dynasty). Under Sesostris I eighty blocks were put on the quay at Koptos; under Sesostris II, two hundred blocks. The mode of working is described as follows : When the commander of the expedition had fixed his choice upon a boulder which seemed suitable for the monument he had in contemplation, it was pushed down the mountain-side, thence to be dragged by manual power. But as the success of this operation was often preceded by several failures in consequence of the stone breaking in the course of its downward rush, in the year 19 of Amenemhat III, the clerk of the works, Meri, conceived the idea of building up an inclined ramp, which made it possible for him to transport six statues. The commemorative inscriptions give information as to the number of men required for these expeditions. The eighty stones of Sesostris I necessitated three shifts, one of two thousand, another of five hundred, and the third of a thousand men, and the journey, which a single caravan can now accomplish in three days, was completed in fourteen. Under Mentuhotep II (XIth dynasty) three thousand men took part in an expedition sent out to find suitable stone for the cover of a sarcophagus. On the second day of a certain month the miraculous intervention of a gazelle led to the discovery of the appropriate block; on the I 5 th a commemorative monument was erected; on the 23 rd the stone 
was successfully detached from the mountain-side, and on the $27^{\text {th }}$ was ready to be carried away. Inscriptions of the same kind are written on the granite blocks of the Assuan quarries.

When, instead of using blocks of stone already detached from the matrix, the Egyptians came to work a hard bed of stone, they cut grooves, marking out blocks of regular measurements, which were parted from the matrix by means of wedges saturated with water or by means of fire. On the Gizeh plateau, near the pyramids, the clearest traces of such methods of working have been found. (25) A typical example is furnished by the remains of the workings of an open quarry near Kertassi in Nubia, (26) whence came the majority of the sandstone blocks used in the building of the temples on the Island of Philæ. In other places the working was accomplished by excavating the interior of the mountainside, which gave rise to the great chambers supported by a series of pillars which were left standing as part of the rock itself.

Metals.-Copper appears rarely in the form of small objects in the primitive tombs of Upper Egypt, but is freely used in the Ancient Empire. Bronze is commonly employed, particularly from the commencement of the Middle Empire. Copper and bronze were worked with the hammer or cast in moulds. The Egyptians made metal vases from the Ist dynasty onwards, and copper statues from the VIth dynasty.

The use of iron is quite exceptional, but gold, electrum and silver were frequently used in jewellery and in inlaywork. Iron was not freely employed until Roman times. Copper came from Sinai, and the precious metals chiefly from the region of the Upper Nile.

Various Materials.-Industrial art made use of quite a number of other materials : ivory, leather, wicker-work, and vitreous pastes. It is as well to observe that transparent glass and blown glass did not make their appearance until the Roman Period.

Use of Materials in Architecture.-The Egyptians often combined different materials : brick and wood or brick and 
stone. The great brick tomb of Naqada was roofed with wooden joists. In many temples the main construction was of brickwork, whilst stone was reserved for door-frames. Sometimes, again, the first part of a building is constructed of bricks, whilst the centre or posterior chambers are of stone. Different kinds of stone may be employed in one and the same building. The core, for example, is of limestone and the casing of granite. We may instance the fine granite doorway of the temple of Deir-el-Bahari, made of three huge blocks which are framed by walls of white limestone. In the temple of Sahure at Abusir the pavements and lower chambers are of basalt, the walls of limestone, and the columns and door-frames of granite.

Sometimes an edifice, built on to the side of a mountain, is continued into the interior of it, one portion of its chambers being then an excavation. The temple of Wady-es-Sebua (27) displays two courts, with their containing walls and pylons of brickwork; the third court, as well as its pylon of stone, and the hypostyle hall and sanctuary excavated in the mountain. When an edifice is built partly in front of a mountain and partly hewn into it, it constitutes what is known as a hemispeos; the temple of Wady-es-Sebua is one example, that of Deir-el-Bahari is another.

Again, an edifice may be entirely rock-hewn. The largest temple of Ramesses II, that of Abusimbel, is the best-known of the type to which the name speos has been applied. This kind of excavation was used mainly for tombs, which the Egyptians hewed in great numbers in the mountain-sides. Later on we shall meet with examples, of which the tombs of Beni-Hasan are certainly the most celebrated examples. It is quite possible that small buildings of brick were constructed against the mountains, but if so all traces of them have entirely disappeared.

In some places rock-cut tombs have been left unfinished, and by their means we can trace the method of working employed by the ancient Egyptians. They began by cutting the upper part, which was completed before deepening the excavation down to floor-level. Thus in certain tombs finished columns may be seen in one half of a chamber, 


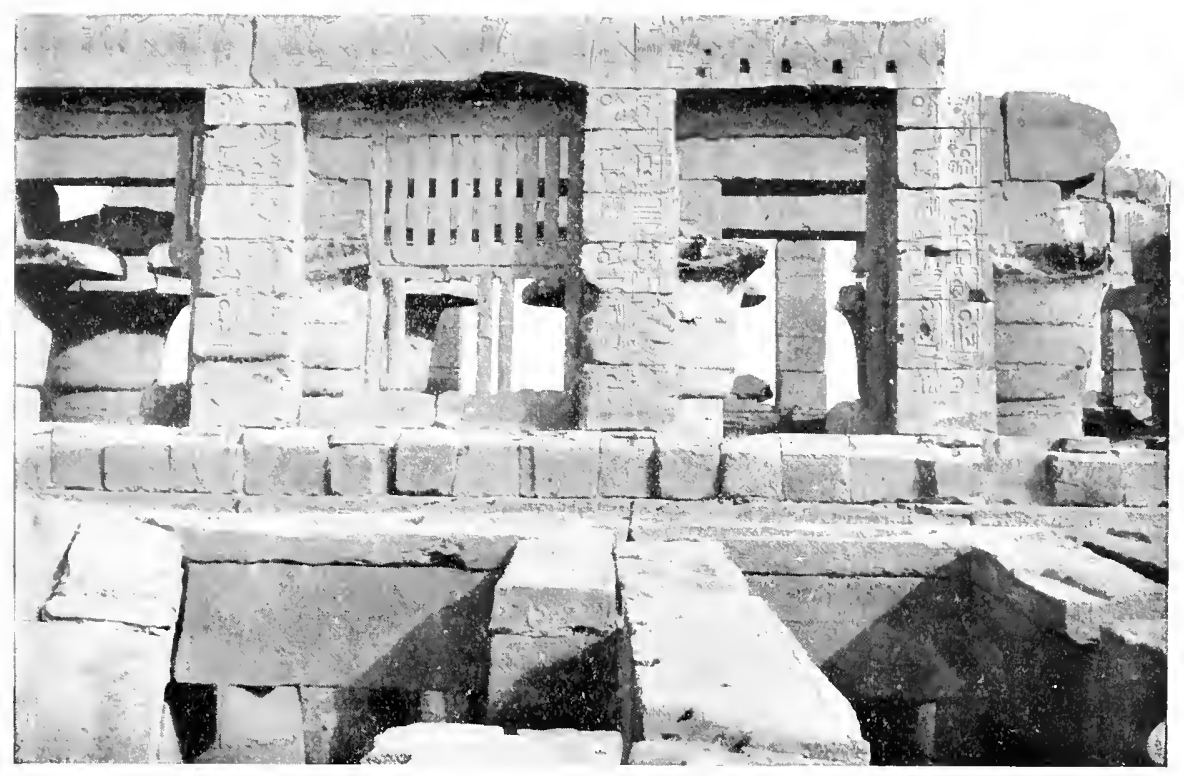

WINDOWS IN THE HYPOSTYLE HALL AT KARNAK 


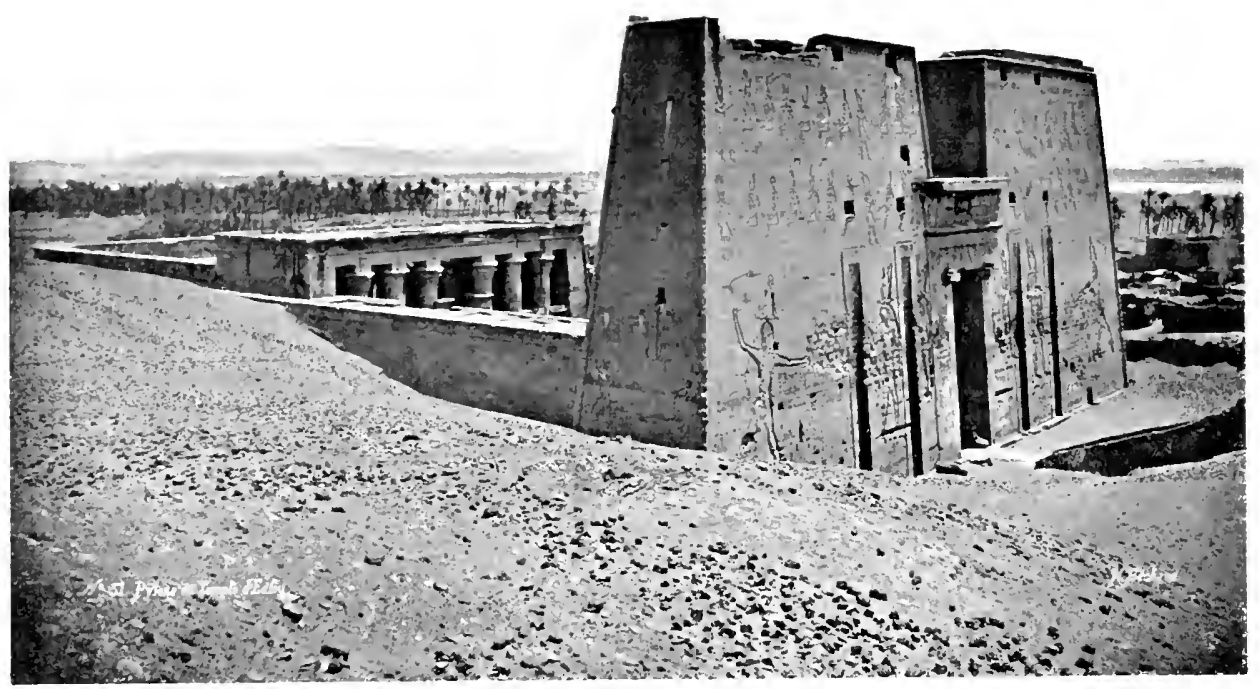




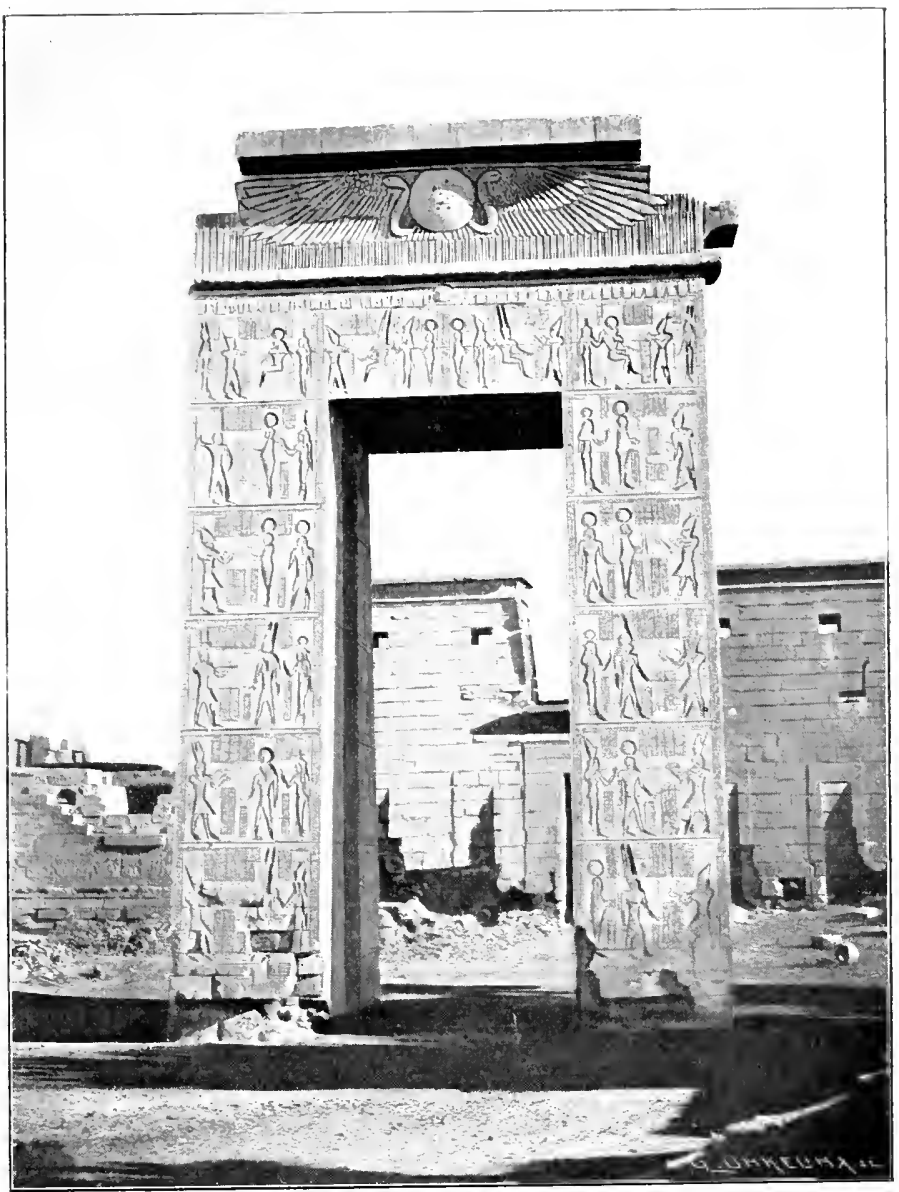

PROPYLON OF THE TEMPLE OF KHONSU AT KARNAK 


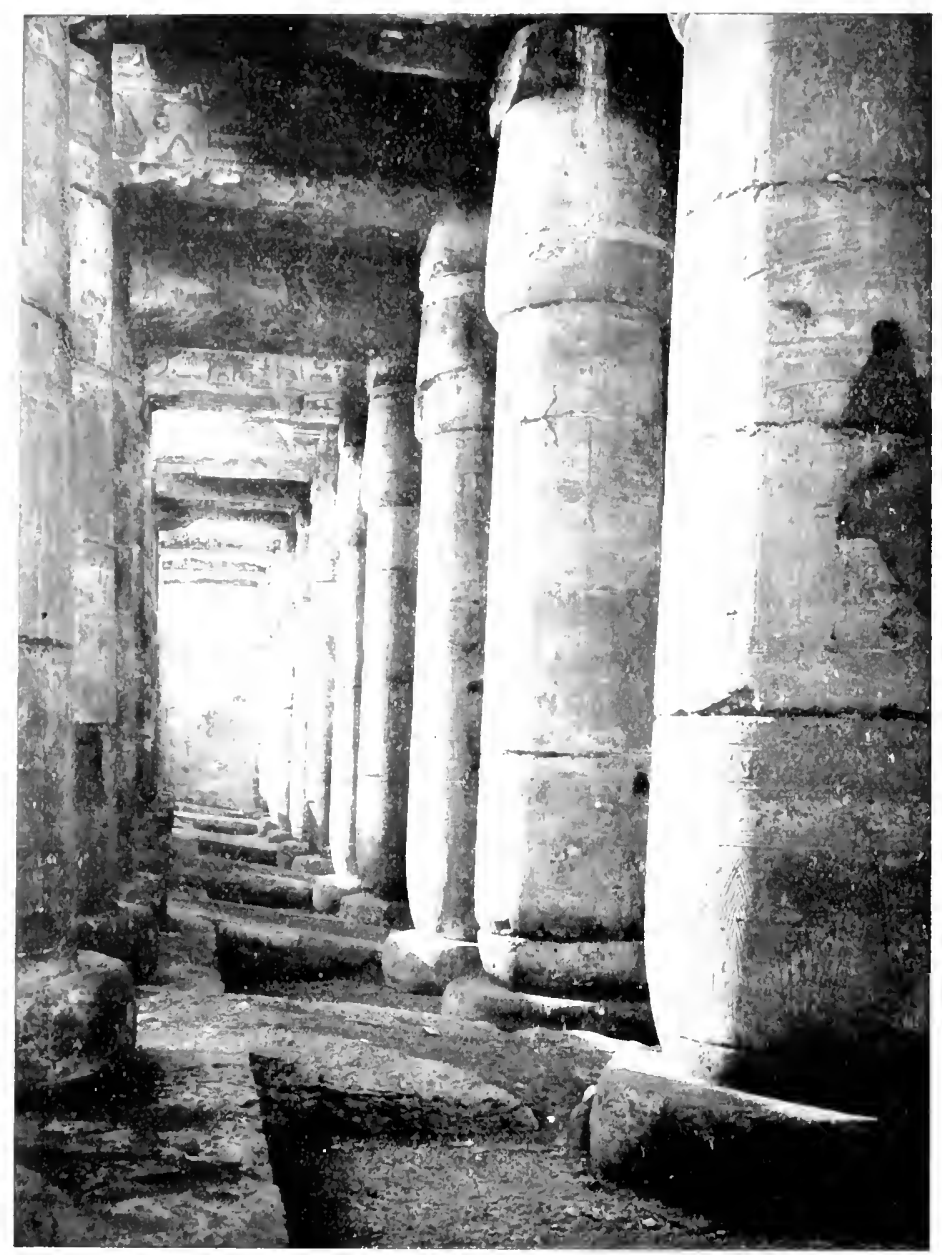

SECOND HYPOSTYLE HALL OF TIIE TEMILE OF SETI I A'I ABYDOS 
whilst in the other half only the upper portion has been cut out of the mass of rock. (28)

Dressing.-In stone buildings the walls are usually made with clean-cut joints without ties of any sort. Sometimes, however, metal clamps were used or dovetails of sycomorewood. (29) When mortar was used, it consisted of lime or of sand and lime mixed; in late times it was made of sand or of lime and pounded bricks. The exterior dressing is sometimes regular, but just as often irregular, blocks of very different sizes being laid one beside the other. The irregularity of this dressing was concealed beneath a coating of plaster which gave the wall a homogeneous appearance.

Foundations.-Generally the foundations are of very slight depth. The soil of the Nile Valley, compact and tough, undergoes contraction when the waters recede, which leaves it incapable of compression: the weight of the materials causes it to attain its maximum degree of settlement and assures a firm seating for the building. Unhappily, owing to the progressive raising of the Nile Valley, infiltrated water is reaching the foundations of edifices more and more, and their solidity is thus seriously threatened. During recent years the Egyptian Service of Antiquities has had to contend against the risks of destruction of the Egyptian temples whose foundations had been weakened in this way. One can see, for example, by a photograph of one of the walls of the temple of Debod in Nubia, (30) taken before the works of restoration were carried out, how the building was sinking into the shifting soil and the lower parts of the walls falling into ruin. The same state of affairs obtained at Maharraka. (3r) The exterior walls were decaying and exposing the inner parts of the building, and, if strict measures had not been taken in good time, the rows of columns would have fallen over like a set of ninepins.

The texts and bas-reliefs afford numerous details as to the foundation ceremonies of the Ancient Egyptians. (32) The king, accompanied by priests and priestesses who impersonated divinities, laid the first stone, made an offering to the gods of specimens of the building materials, and consecrated under the angles foundation deposits consisting 
of pottery, model tools, amulets, and tablets bearing commemorative inscriptions. (33)

Technical Processes. - When one considers the great size of the materials used by the ancient Egyptians in their monuments-stones of huge size, statues and sarcophagi of almost fabulous weight-one cannot help asking how they managed to place in position such huge masses. In the pyramid-temple of Khephren granite blocks will be observed in the vestibule, weighing 38 and 42 tons, and in one case I 50 tons. In the temple itself on the plateau, there is one granite block of a cubic capacity of more than 170 cubic metres and a weight exceeding 400 tons. (34) The architraves to the hypostyle hall at Karnak measure over 9 metres in length, their cubic volume is 3 I cubic metres, and their weight 60 tons. The pillars in the Osireion at Abydos weigh 90 tons. (35) The celebrated sarcophagi of the sacred bulls in the Serapeum at Memphis weigh 60 tons. (36) The colossus of Ramesses II, which lies shattered in the courtyard of the Ramesseum at Thebes, was I7.5 metres in height and weighed more than I,000 tons.

How did the Egyptians manage to transport and set in position such huge masses? The mechanical appliances which they had at their disposal, as far as we know them, seem to have been very limited. A machine for irrigation purposes, similar to the modern shadouf, proves at least that they understood the functions of levers. We shall presently see that they probably also knew the action of the crane, but in most cases it seems clear that they used nothing but the power of human arms.

Pictures of dragging blocks of stone or monuments are rare, and they are generally concerned with the transport of funerary statues of no great size. They were placed on sledges drawn by a gang of men, and the gliding was assisted by watering the ground. Upon one stele in a quarry, as an exception, a block of stone is scen on a sledge drawn by oxen. (37) In the temple of Deir-el-Bahari a bas-relief is devoted to the transport of two great obelisks of Queen Hatshepsut. The two monuments are laid end to end upon the same barge towed by a regular flotilla of boats. (38) 
The tomb of Tehuti-hetep at El-Bersheh contains the celebrated scene of the transport of a colossus. (39) It may be gathered from the accompanying texts that this alabaster statue weighed about 50 tons. It is placed upon a sledge drawn by $\mathrm{I} 72$ men. It is probably incorrect to imagine that the Egyptian draughtsmen wished to represent the exact number of men required for the transport ; they merely sought to convey the impression of a great number of men pulling simultaneously at the ropes which gave the motive power to the sledge, for in this case I 72 men would scarcely make up a sufficient crew. We have actually seen, in connection with working the quarries, the mention of very high numbers. The composer of the inscription perhaps tried to rectify the discrepancy between the weight and the number of men who shifted it by stating that their enthusiasm was so great that each man pulled like a thousand.

A passage in the Papyrus Anastasi No. I (40) would be of first-rate importance for the study of these questions, if it were possible to solve with greater accuracy the different problems enunciated by the technical terms employed. A scribe writing a sarcastic letter to one of his rivals sets him some constructional problems which he hopes his rival will be quite unequal to solving. The principal question is concerned with a brick ramp which had to serve for the erection of an obelisk. It would seem that the Egyptians frequently made use of these ramps, and excavations amongst Ancient Empire monuments have sometimes led to the discovery of traces of them.

The selfsame system was revived, in our own times, by Legrain, in the works of reconstruction and consolidation which he carried out in the hypostyle hall at Karnak. The problem, a difficult one, was to make good the foundations of the columns which had shifted, but in order to do that he had first to lift off the architraves and then in succession the stone drums of which the pillars were built; it was not until this had been done that it became possible to reset the foundations solidly in concrete, then to refit the successive parts of the columns and replace the architraves. These latter were, as we have seen, blocks of very consider- 
able weight and size. Legrain had recourse to the following method : he filled up the hall with earth and sand to the level of the architraves, he then made an inclined plane, and succeeded in sliding the blocks off on rollers one after another down to the ground level; and afterwards, by reversing the process, he accomplished the restoration in perfect order. Never, however, was any other power employed than the muscles of his Karnak workmen.

Against the inner face of the great pylon of Karnak were discovered the remains of brick stagings which were used in the course of its building. (4I) As a stone edifice rose up, so it was surrounded in one way or another by another construction of crude bricks which rose up step by step in time with it, forming a sort of gigantic staircase on which the materials were raised without excessive difficulty. When the builders had reached the top of the walls the edifice was hidden from view within this casing of crude bricks, and now began the work of the sculptors who had to complete the decorative work. In proportion to the advancement of their work, the brick scaffolding was taken down stage by stage. It is thus that in an angle of the court of the Bubastides at Karnak, where the capitals of the portico are only rough-hewn, the columns are still masked in a mass of crude bricks.

In Choisy's work (42) on the art of building of the Egyptians will be found mention of an apparatus known as the oscillating elevator, which must have assisted the Egyptians in the erection of their monuments. Models of this contrivance have been found with other models of tools in the foundation deposits of several temples.

We know from a Saqqara tomb of the Persian period that in some cases the Egyptians made use of sand in the process of setting in position the colossal lid of a sarcophagus. (43) There we see a most ingenious arrangement of cavities filled with sand in which rested the ends of the posts which upheld the lid. By letting out the sand from below, the posts sank slowly down in the cavities, and finally lowered the lid into its place with great precision.

Borchardt has called attention to the presence of grooves 
in the upper part of the pedestals of obelisks and statues. (44) Of these grooves, some served to prevent the monument from slipping during its sharp movement, whilst others were probably employed in the use of a system of stops to hold the mass in its place during erection.

M. Hölscher, in his careful architectural study of the temple of Khephren at Gizeh, has observed a whole series of indications by which we can reconstruct the very ingenious working of grips for lifting blocks operated by means of a crane. (45)

\section{BIBLIOGRAPHY.}

I. Petrie, W. M. F., The Sources and Growth of Architecture in Egypt, in the Fournal of the Royal Institute of British Architects, Third Series, vol. viii., n. I4, I $90 \mathrm{I}, \mathrm{pp}$. 34I sqq. The Arts and Crafts of Ancient Egyptians, Edinburgh and London, I909, p. 63. See for another explanation Lethaby, W. R., Architecture (Home University Library), London, p. 29.

2. Petrie, W. M. F., Gizeh and Rifeh. London, I907.

3. Wreszinski, W., Atlas zur altägyptischen Kulturgeschichte, Leipzig, I9I4, pl. 60.

4. Newberry, P. E., The Life of Rekhmara, London, igoo, pl. XXI.

5. Petrie, W. M. F., Egyptian Bricks, in the Journal of the Archcological Institute, vol. 40, I882 (The Domestic Remains of Ancient Egypt).

6. Petrie, W. M. F., Abydos, Part II, London, I903, p. 20.

7. Choisy, A., L'Art de bâtir chez les Egyptiens, Paris, I904, p. 4 I.

8. Prisse d'Avennes, Histoire de l'Art égytien, Paris, 1878, t. i., pl. 46.

9. Choisy, A., op. cit., p. I3.

Io. Reisner, G. A., The Early Dynastic Cemeteries of Naga-ed-Dêr, Leipzig, I908, pl. $65 a$.

II. Petrie, W. M. F., Medum, London, I892, pl. VII.

I 2. Garstang, J., Tombs of the Third Egyptian Dynasty, London, I904, pl. I 4 .

I 3. Petrie, W. M. F., Dendereh, London, I 900 , Frontispiece.

14. Choisy, A., loc. cit., pl. XI ; Baraize, E., Déblaiement du Ramesseum, in the Annales du Service des Antiquite's, t. viii., I 907 , pp. I98 sqq.

15. Jéquier, G., Les Temples memphites et thebains, Paris, ig20, pl. 36 n. 2 .

16. Ibid., pl. $35, \mathrm{n}$. I and 2.

17. Maspero, G., Les Temples immergés de la Nubie. Rapports relatifs a la consolidation des temples, Cairo, I9I I, pl. CXXIX, b.

I 8. Daressy, G., Notice explicative des ruines de Medinet Habou, Cairo, I $897, \mathrm{PP} \cdot 35-36$. 
I 9. Piéron, H., Un Tombeau egyptien à coupole sur pendentifs, in the Bulletin de l'Institut franfais d'archéologie orientale, Cairo, t. vi., I908, pp. 173-I77 and plate.

20. Mace, A. C., in Randall-MacIver, D., and A. C. Mace, El Amrah and Abydos, London, I902, p. 65 and pl. XXVIII.

2 I. Petrie, W. M. F., Abydos, Part II, London, I903, pl. VIII.

22. Maspern, G., The Dawn of Civilization, $5^{\text {th }}$ edition, London, r9ro, p. 243.

23. I.epsius, R., Denkmäler, Part II, pl. I9.

24. Couyat, J., et P. Montet, Les Inscriptions hiéroglypliques et hiératiques du Ouâdi Hammâmât, Cairo, I 9 I 2.

25. Hölscher, U., Das Grabdenkmal des Königs Chephren, Leipzig, I 9 1 2, fig. I 9, p. 33 .

26. Röder, G., Debod bis Bab Kalabsche, Cairo, r9i r, pl. 66.

27. Gauthier, H., Le Temple de Ouâdi es-Seboua, Cairo, I9I 2, pl. A.

28. Bouriant, U., G. Legrain, et G. Jéquier, Monuments pour servir à l'étude du culte d'Atonou en Egypte, Cairo, I903, pl. XXXVI.

29. Leemans, C., Aegyptische Monumenten von het nederlandsche Museen te Leyden, II, Leyden, 1846, pl. 89, n. I 49.

30. Maspero, G., Les Temples immergés de la Nubie. Rapports relatifs à la consolidation des temples, Cairo, I9I I, pl. XLII.

3 I. Ibid., pls. XCIX-CI.

32. Lefébure, E., Rites égyptiens. Construction et protection des édifices, Paris, I 890 .

33. Petrie, W. M. F., Koptos, London, I 896 , pl. XVI ; Abydos, Part II, London, I903, pls. LXII-LXIII ; Naville, E., The Temple of Deir-el-Bahari, Part VI, London, I908, pl. CLXVIII, etc.

34. Hölscher, U., Das Grabilenkmal des Königs Chephren, Leipzig, I 9 I 2, Pp. 40 and 52 .

35. Borchardt, L., Die diesfährigen Ausgrabungen des englischen Egype Exploration Fund in Aegypten (I9I3-I 4) in Klio, I9 I 5, Pp. 498 sq9.

36. Linant-bey, Poids d'un des sarcophages de la Tombe d'Apis, in Mariette, A., Le Sérapeum de Memphis, Paris, I 882, p. I I 3 .

37. Lepsius, R., Denkmäler, Part III, pl. 3 .

38. Naville, E., Transport of Obelisks, in the Ariheological Report of the Egypt Exploration Fund, I 895-I896, pp. 6-I 3 and plate.

39. Newberry, P. E., El Bersheh, Part I, London, i 894, pl. XV.

40. Gardiner, A. H., Egyptian Hieratic Texts, Part I, Leipzig, I9I I, pp. 31* $34^{*}$; Barber, F. M., An Ancient Egyptian Mechanical Problem, in T'he Open Court, Chicago, December 1912.

41. Choisy, A., L'Art de bâtir chez les Egyptiens, Paris, I904, p. 89.

42. Ibid., pp. 80 sqq.

43. Barsanti, A., Note sur le procédé qui servait à descendre sur le cuve le gros convercle des sarcophages en calcaire, in the Annales du Service des Antiquites, t. i., I900, pp. $283-284$.

Capart, Jean, Un probléme de mécanique éguptienne, in the Annales de la Societé d'archélogie de Bruxclles, t. xv, I90I, pp. 232-235.

44. Borchardt, L., Zur Baugeschichte des Amenstempels von Karnak, in 
the Untersuchungen zur Geschichte und Altertumskunde Aegyptens, by Sethe, t. v., Leipzig, I912, pp. 15-17; Die Aufstallung der Memnonkolosse, in the Zeitschrift für Aegyptische Sprache, t. xlv., 1908, pp. 32-34.

45. Hölscher, U., Das Grabdenkmal des Königs Chephren, Leipzig, I 91 2, pp. $74-76$.

See too for the questions of Egyptian mechanics:

Barber, F. M., The Mechanical Triumphs of the Ancient Egyptians, London, 1900, and Zimmer, G. F., Engineering of Antiquity, London, no date (I9I4). 


\section{CHAPTER VII \\ FUNDAMENTAL FORMS IN ARCHITECTURE}

\section{The Pillar.}

W

E must now endeavour to define as far as possible the general characters of Egyptian architecture. If we consider as a whole the monuments which have been preserved, we are immediately struck by the fact that the architecture of Ancient Egypt has produced above all massive structures with little exterior architectural adornment. The forms may be said to be of the simplest : thus in the pyramid or the mastaba the outer walls slope inwards, and end, in the first case, in an apex, and, in the second case, in a rectangular platform of an area less than that of the base of the monument. The architectural masses, on the contrary, may be looked upon as complexes, in the sense that buildings may present a series of constructions of different sizes abutting one upon another: thus upon the pyramid or mastaba abut the buildings which constitute the temples or funerary chapels. In Borchardt's restoration of the temple of Sahure (I) will be found a typical example of this aspect of architecture. One will be struck by the paucity of openings : a few slits in the walls serve as windows, and a great rectangle cut out of the roof marks out the portico court.

The only ornamentations noticeable at first sight are the cornices and the torus, and even these have no true value as ornaments, since they are derived from the process of building. This kind of decoration appears on the tops of the walls as well as over doorways. The cornice was 


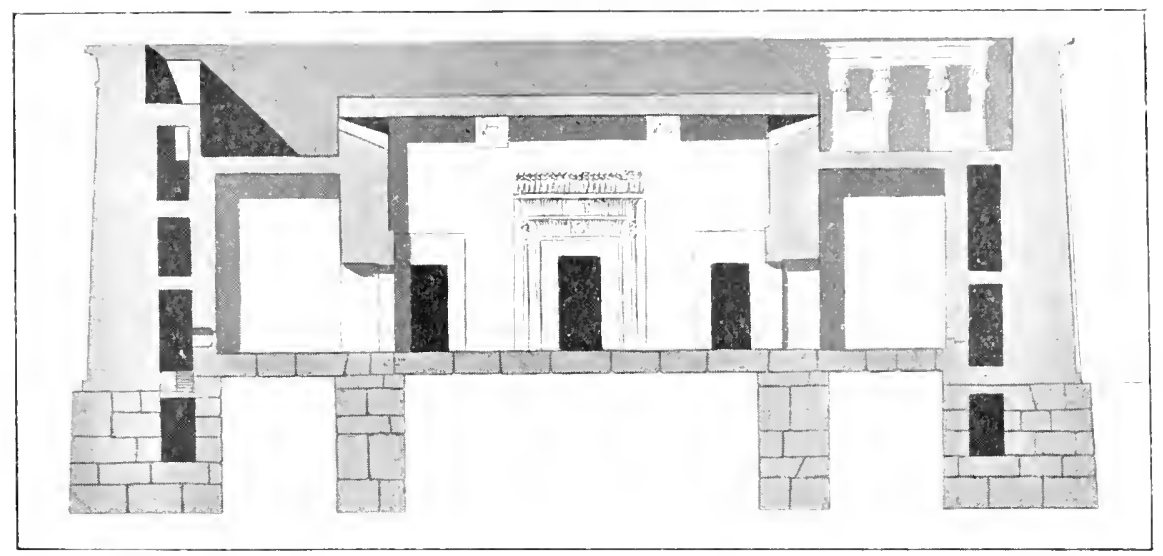




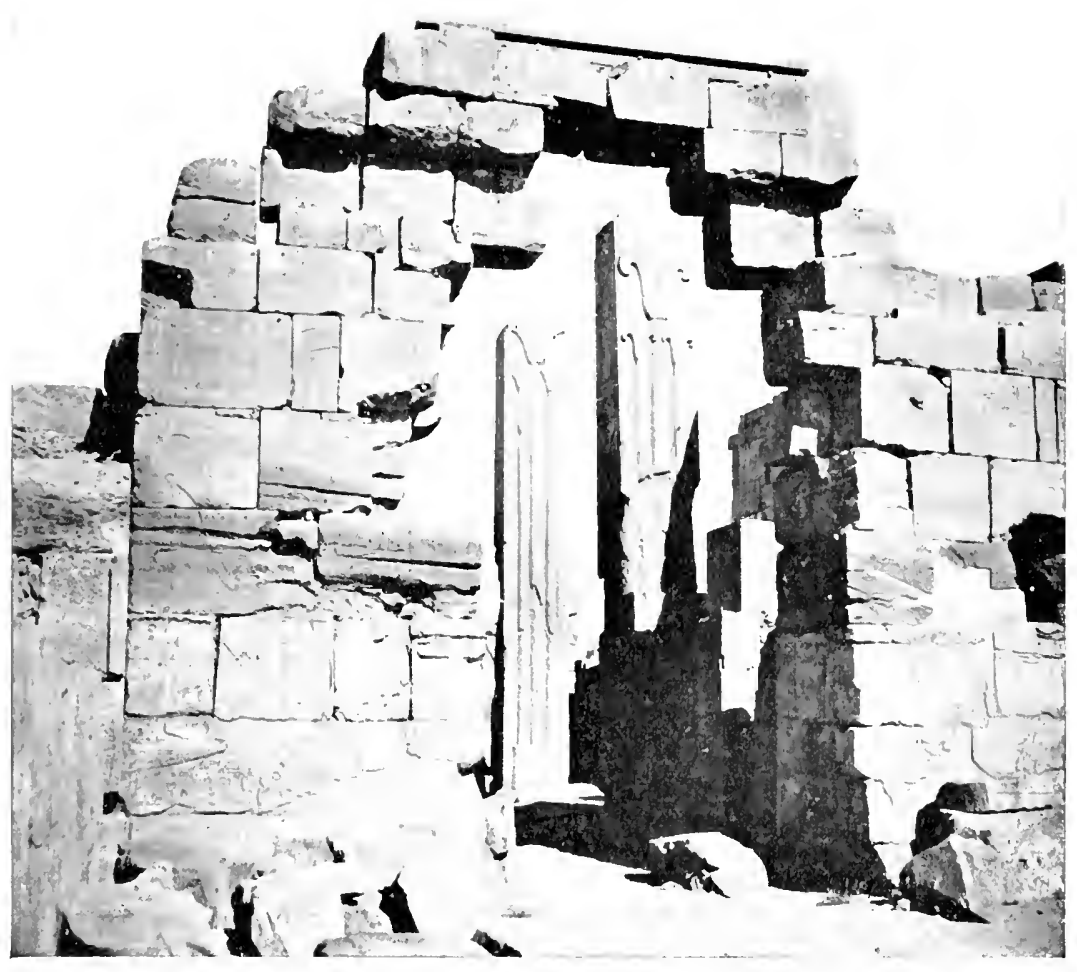


often surmounted by a frieze of sacred serpents or rearing urei, their heads crowned with the solar disk. In the gorge were designed palm-leaves or a series of royal cartouches. The winged disk, commonly placed on the door-lintels, sometimes spreads widely over the gorge itself. (2)

An element whose outline breaks the monotony of the great buildings is the pylon, which consists of a doorway flanked by two high towers. The towers probably owe their form to the storied buildings in mud or brick : Egyptian architecture in Upper Egypt copies this arrangement even in our own times. We may observe that in the temple of Abusimbel recent excavations have led to the discovery of a little sanctuary the general form of which reproduces the arrangement of the pylon, but without a door. (3) One is tempted to question whether the door is really an essential element in the pylon, or whether the anomaly shown in the case of the Abusimbel temple can be explained by some local peculiarity. In most temples, at least from the time of the New Empire, the pylon becomes the dominating feature under the form of a gigantic portal, whose towers exceed in height the level of all the surrounding structures.

The great pylon of the Edfu temple (4) affords an opportunity of analysing the general form and of seeing particularly how the door, conceived as a separate element, is sandwiched in between two great lateral piles. In the faces of each of these long vertical grooves rise nearly to mid-height; and above, rectangular openings are pierced right through the masonry. Originally long wooden masts were set in these grooves, where they were fixed by means of cables passing through the openings. Several bas-reliefs give very precise representations of this. (5) These masts, wrapped about by a kind of bandage and set up before the pylon, seem to have served as emblems or badges denoting sacred buildings, if it be true, as there is every reason to think, that the hieroglyphic sign for "god" in Egypt represents a mast surmounted by one or several bandages as a flap. In each of the towers a staircase of forty-two steps gives access to the platform above. Small openings serve to light the stairway passage. 
The monumental doorways which stand in front of the pylons are called propylons, and they are chiefly known in connection with the Ptolemaic period. At the present day they appear isolated, although they really formed the entrances to the great boundary walls of brick which marked out the sacred precincts of the temple. Their form is identical with that of the doorways in the interior of the edifices; it is probably merely by chance that we find them only in late times.

The thickness or embrasure of Egyptian doorways is generally very deep. Recesses were sunk in the thickness to receive the open leaves of the door. An example at Wady-es-Sebua is interesting in connection with the decoration which was placed upon the embrasures. (6) The door of the sanctuary was a single one, and on the side to which it was hinged and on to which it opened back it sufficed to inscribe a series of royal titles; but on the opposite side, which was never hidden by the open door, a figure of the god of the sanctuary was drawn coming out to meet the king, extending a hand towards him and holding the symbol of life to his nostrils.

Looking down the principal axis of an Egyptian temple, through all the doorways, which are generally set in line, a progressive rise in the ground-level is noticed. This change of level may be scarcely noticeable, as, for instance, at Kalabshi, (7) where a gentle slope before each door compensates for this difference in plane. In other temples the elevation is more considerable, and necessitates a system of ramps or stairs, as, for example, at Deir-el-Bahari (8) or at Wady-es-Sebua. (9) Here the first stone pylon is erected on a terrace which is reached by a wide stairway; the second pylon is placed upon a less elevated terrace, access to which is again given by a staircase, divided into two bays by a ramp between them. (IO) It is probable that this type of double staircase with a central ramp was brought about by the exigencies of moving the sacred shrines, which were brought out from the inner chambers of the temple on the occasion of certain festivals.

The difference of level might have been explained by 
the lie of the land itself were it not that we meet with it where there is no sign of a cause to require it. Thus, in the court of the temple of Khonsu at Karnak, one gets the impression at first sight that all the columns are of the same model and of the same dimensions. The architraves which they uphold run at an even height on closer inspection. However, it will be noticed that the columns at the lower end of the court are longer by several inches than those at the upper end. This is, to our ideas, an offence against good taste and the notions of symmetry. The fact is strange enough, but it appears to be more so when this elevation is made, not in a courtyard, but within a great hall. In the second hypostyle hall of the temple of Seti I at Abydos (I I) the two first rows of columns are at one level and the third at another, slightly higher : ramps, placed at regular intervals, take up the difference. Even in the internal parts of a building where the floor spaces are extremely confined an elevation of the ground will be noticed from door to door, for example, in the rooms which immediately precede the sanctuary at Edfu. The central naos occupies the highest level, and one might well ask if this is not indeed the end at which the architects aimed--an end which was so important to them as to waive all other considerations.

The upward movement of the ground-level has its counterpart in the inverse movement of the roof-level, which is particularly noticeable at Edfu. It will be observed that a rather high wall forms a parapet around the posterior part of the temple, forming an esplanade entirely hidden from prying eyes without. We must observe that it was upon this esplanade that were constructed little shrines used in the cult-ceremonies performed in the open air but quite screened from the profane gaze.

Ceilings were formed by great slabs resting on the architraves. The Egyptians, by the decoration of their ceilings, sought as far as possible to suppress the notion that the edifice was shut in on its upper part. They actually painted on the slabs the blue sky sprinkled with stars, or sometimes they designed large figures of birds in flight. (I2)

The drainage of rain-water was regulated by the 
arrangement of the slabs, which were sometimes gently inclined or even cut out in a manner appropriate to the purpose. The water, which was drawn off in a prevailing direction by this means, poured out through a series of gargoyles. We find them in the temples of late period, (I 3) where they occur in the form of the forequarters of lions whose bodies are merged in the wall at a fixed height exactly corresponding with the level of the roof-slabs, which are bordered by rather a high parapet. A hole and a spout cut between the paws of the animal allow the water to pour off. A few years ago a fragment of a similar gargoyle was discovered at the solar temple of Abu-Gorab, of the Vth dynasty, attesting the antiquity of this type. (I 4)

The lighting of the interior chambers is effected by narrow slits pierced in the walls or by splayed openings in the roofing stones, or again by the use of true windows. Thus, in the vestibule of the temple of Khephren, (I 5) the granite blocks which form the top of the lateral walls have been so carved as to admit beams of light into the hypostyle hall. One might almost ask if this latter method did not lead the architects towards the idea of slightly lifting the roofing slabs. By making them rest on blocks interposed here and there between the ceiling and the tops of the walls they thus gave rise to a series of square openings lighting the hall from the sides. In the case of a hall with several rows of columns it was sufficient to revert to this method for the roofing slabs of the central nave, which consequently led to a difference in level between the ceiling of the central nave and those of the lateral aisles. This may be clearly discerned in the case of the hypostyle hall of the Ramesseum at Thebes. (I6) The more pronounced this difference of level becomes, the more the windows are enlarged. This measure exceeded itself, for after seeking to admit light to the interior, steps had to be taken to prevent too great an intensity of illumination. This is why the opening of the window is filled with a sort of grille carved out of stone, which recalls the window-like constructions in the ornamented stelæ. The hypostyle hall at Karnak furnishes a good example of this type of obstructed window. (17) It 
will be noticed, moreover, that these differences of level which appear to be dependent upon the practical exigencies of lighting, have given rise to the basilica plan employed by the Egyptians at least from the time of the New Empire. A hypostyle hall, whose central nave is higher than the lateral bays, actually unites the fundamental elements of the basilica, such as was built in later times by the Greek and Roman architects. Hypostyle halls were often preceded by a columned courtyard and by porticoes which correspond exactly to the atrium and narthex of Christian basilicas.

One might believe that it was likewise these practical considerations of isolation and lighting which gave rise to two architectural elements : the façade opening and the half-door, which one may see, for example, in the façade of the hypostyle hall at Edfu. (18) Instead of closing in the hall by an outer wall reaching up to the ceiling, the builders contented themselves with building between the columns a wall of about one-third of their height, but high enough to conceal all that went on inside the hall. In this case there was no occasion to cause any difference in level between the central and lateral bays, and the columns are all of equal size. In order to close the screen thus devised between the court and the hall, two masonry jambs were erected between the two midmost columns, forming the embrasure of a double door, with sufficient protrusion towards the top to allow of the fitting of the upper pivots of the doors. Each of the buttresses so formed terminates in a cornice, and we thus have a sort of doorway, but without a lintel. (19)

The necessity of roofing-in spaces too broad to be capable of being spanned by a single beam, whether of wood or stone, as well as the need to shade certain façades by means of a portico, has given rise to architectural supports-pillars and columns.

The pillar, in its simplest form, is derived directly from the use of materials in the form of regular posts of a given height-posts set up vertically form pillars : laid horizontally, they become architraves. This is clearly seen in the case of the granite pillars in the vestibule of the temple of Khephren at Gizeh. (20) Huge posts are set upright on 
the pavement without any kind of pedestal : the architraves rest upon them without any element interposed between them. The erection thus formed, which already holds solidly together by dint of sheer weight, is further secured by metal clamps fastening the architraves end to end at the point where they meet in the centre of the pillar. (2I)

The square pillar, which at Gizeh is of considerable thickness, is used in slenderer proportions in the temple of Amada ; (22) this time, however, a slightly raised base is interposed between the ground and the pillar, as though the aim were to give by way of support a sufficient splay to prevent the earth being forced out by the weight supported above. This base, which here has a more or less logical value, is so raised in other cases as to form a true pedestal, in the temple of Derr, for instance, (23) where, however, architraves, pillars and pedestals are carved out of the rock.

A small temple of Amenophis II at Karnak (24) demonstrates the use of square pillars surmounted by a cornice. This would be quite admissible if, the pillar being considered as a piece of wall, the architrave had rested directly on the upper edge of the cornice; but the Egyptian architects interposed between them a square stone, serving as an abacus, which conveys the impression that the pillar continues upwards inside the cornice. The same feature is to be found in the tomb of Tutu at Tell-el-Amarna, (25) where square pillars with a cornice near the top are of one piece with the wall and appear to support the ends of the great cross-beams (" appear to support," because in reality the whole tomb is carved out of the solid rock). In connection with these pillars enclosed in a wall, it is interesting to note that the exterior walls of the portico at Amada are built up as if they were between pillars, thereby forming, both within and without, a series of panels separated by pilasters. (26)

The square pillar is often decorated with sculptured or painted scenes, generally depicting the king in the presence of some divinity. In the temple of Karnak, in front of the sanctuary, two granite pillars rear themselves which conform 
to this type, but with this peculiarity-that they present two faces ornamented by floral devices in very high relief. (27)

On the southern pillar are the plants which symbolise Upper Egypt, which are called, for want of a better name, lilies; the northern pillar displays the papyrus plant, the symbol of Lower Egypt. It is possible-indeed, several archæologists believe-that these pillars served as pedestals for statues of gods; might they not have been, however, the remains of an ancient construction as Borchardt would have it? (28)

Some temples have square pillars bearing reliefs of the sistrum of Hathor, as, for instance, the small Ptolemaic temple of Deir-el-Medineh. (29)

It would seem that the origin of square pillars is to be sought in the craft of the stone-worker. The supports which the quarrymen have left from place to place to stay up the roof in quarries hewn out of the mountain-side have merely been imitated in buildings. When, on the contrary, we meet with a polygonal pillar, with more or less numerous faces, we are tempted to infer a prototype of wood. Indeed, we have seen that the polygonal pillar figures amongst the ancient hieroglyphs, and that its upper part ends in a tenon, and further, that each of its faces bears a groove or channelling, all of which imply imitation of woodworking.

The polygonal pillar, in miniature size, is also frequently reproduced in wood or ivory. It is to be found combined with other forms in the hatchwork of windows. Thus, in the sanctuary of Aashait, in the XIth dynasty temple of Deirel-Bahari, (30) the painted stone imitation of a windowgrating displays a multitude of open-work devices: the floral motif of the ornamented stelæ, rows of falcon heads, the amulette called dad or didiu, and finally polygonal pillars, placed in pairs.

The most ancient eight-sided pillar appears in the tomb of Ptah-hetep I at Saqqara. (3I) Again, we find it in the XIth dynasty temple at Deir-el-Bahari, (32) where the stone is sandstone covered with a whitish plaster. The pillar at Deir-el-Bahari rests upon a round basis sculptured on the surface of a square block which is in one piece with the 
floor-slabs. The façade of the tomb of Chnumhetep II at Beni-Hasan (33) displays the use of polygonal pillars with twelve faces. The top is separated from the architrave by a square flat abacus, which juts out above the four oriented faces of the pillar. (I call "oriented faces" the four faces which adjoin the ends of the two axes of the pillar.)

In the New Empire, the polygonal pillar is used principally at Deir-el-Bahari and at Karnak. (34) In the colonnade and porticoes of Anubis at Deir-el-Bahari the sixteensided pillars are slender and of elegant proportions, recalling Greek architecture perhaps even more than the pillars of Beni-Hasan. Indeed, we know that Champollion, and other archæologists after him, gave the name of "Protodoric" to the Beni-Hasan pillars. Without entering here into any discussion as to whether or no Greek architecture owes anything to Egyptian, we will content ourselves by noting that the architects of the Middle and New Empires employed an architectural element which at once suggests the idea of comparison with the forms of classic art. The first Greek emigrants to reach Egypt must have seen these monuments; and can this knowledge, therefore, have in any way favoured the development of Doric architecture? It would be equally rash to affirm or to deny it too summarily, for the polygonal pillar can quite easily be conceived to have attained independent, though similar, development both in the Nile Valley and upon Greek soil.

The pillars of the Anubis portico at Deir-el-Bahari rest upon circular bases, and the upper parts terminate in abaci all cut in a piece from the same block from which the sixteensided pillar emerges. The surfaces of the four oriented faces of the pillar are flush with the faces of the abacus. In other words, drawn in plan the sixteen-sided polygon is described exactly in the square of the abacus.

In the temple of Seti I at Abydos, in the third row of columns in the second hypostyle hall, we come across a new and rather singular development. (35) The polygonal pillar, with its four oriented faces, absolutely flat, is nevertheless transformed into a kind of round pillar, if one might so express it. In point of fact, between the four faces, where 


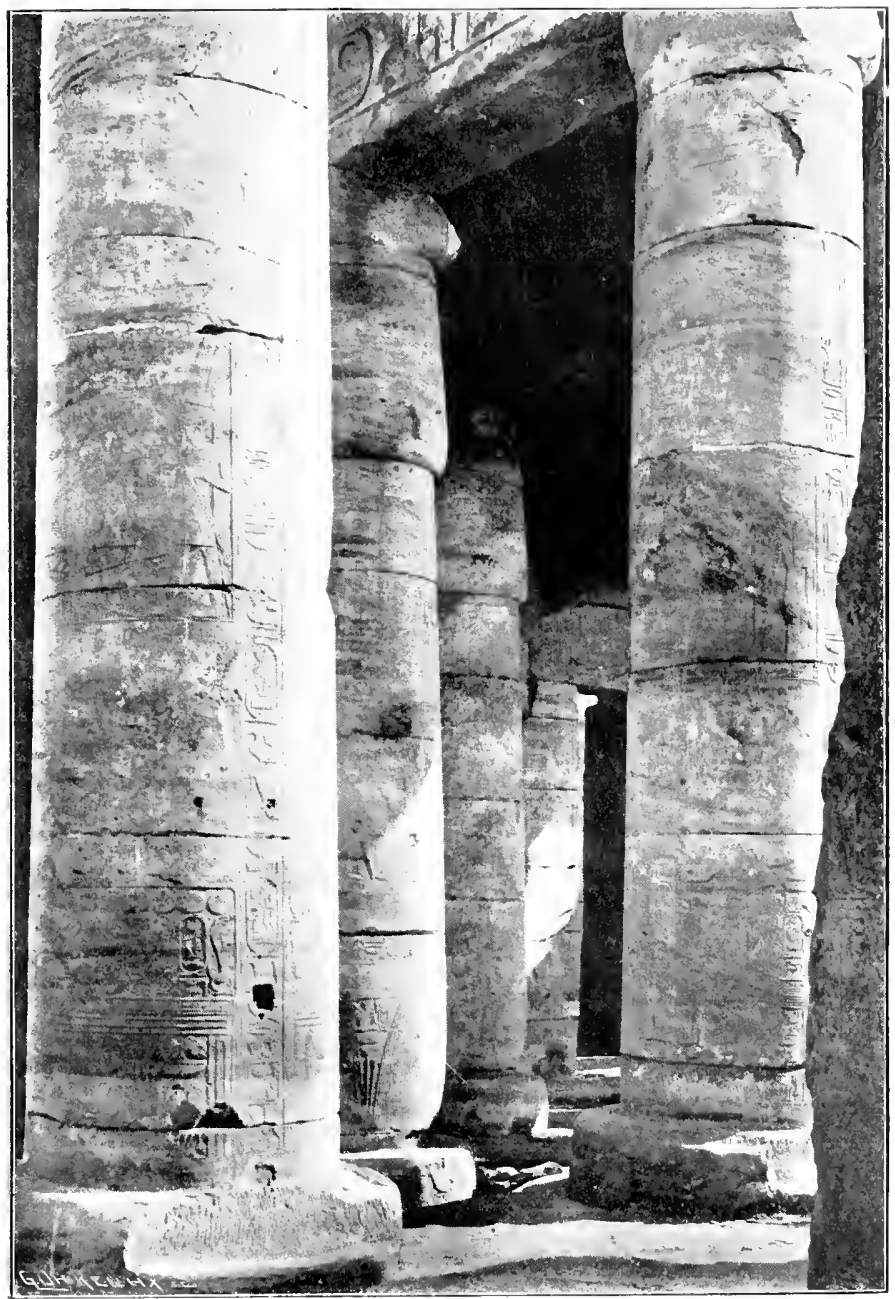

PILLARS IN THE SECOND HY'POSTYLE HALL OF SETI I AT ABYDOS 


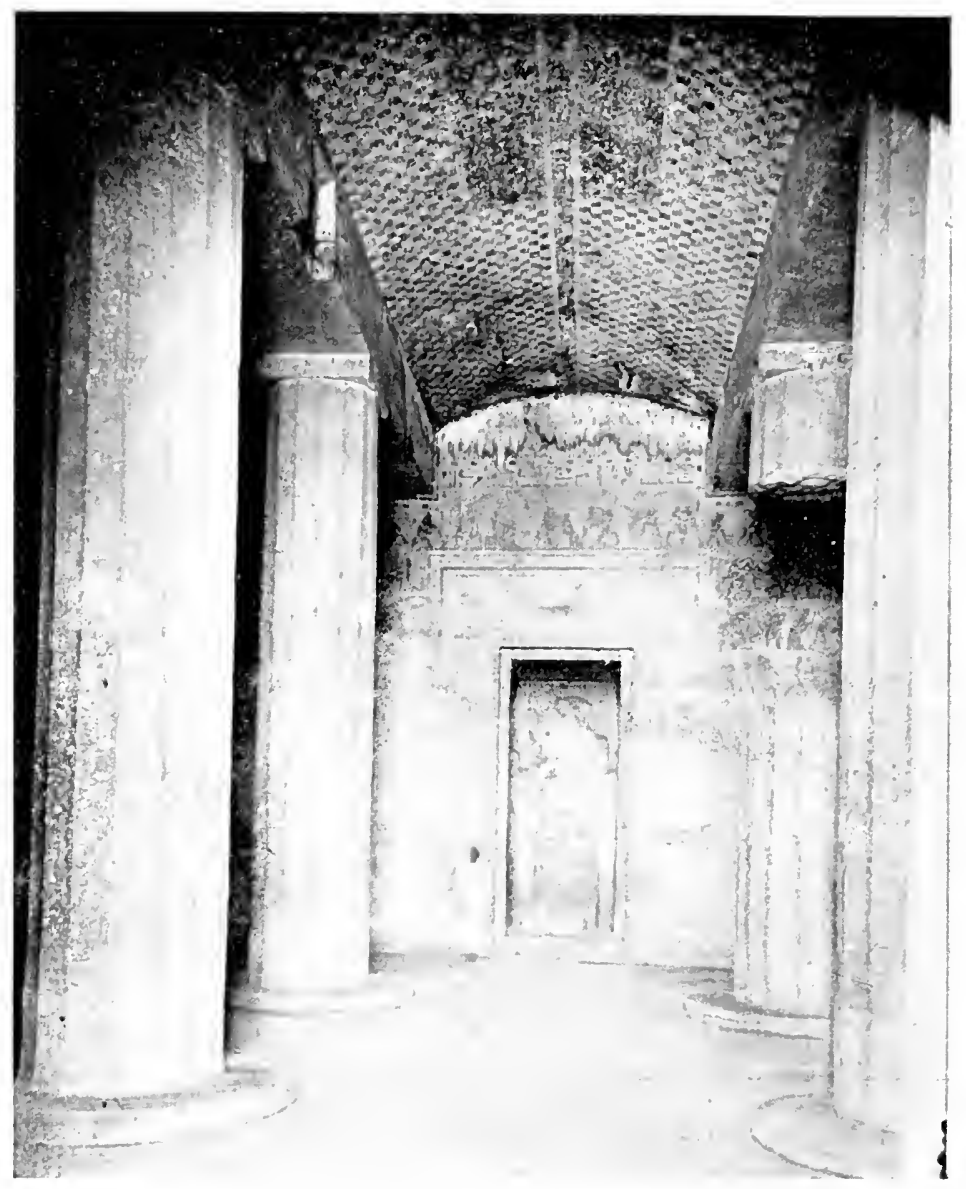




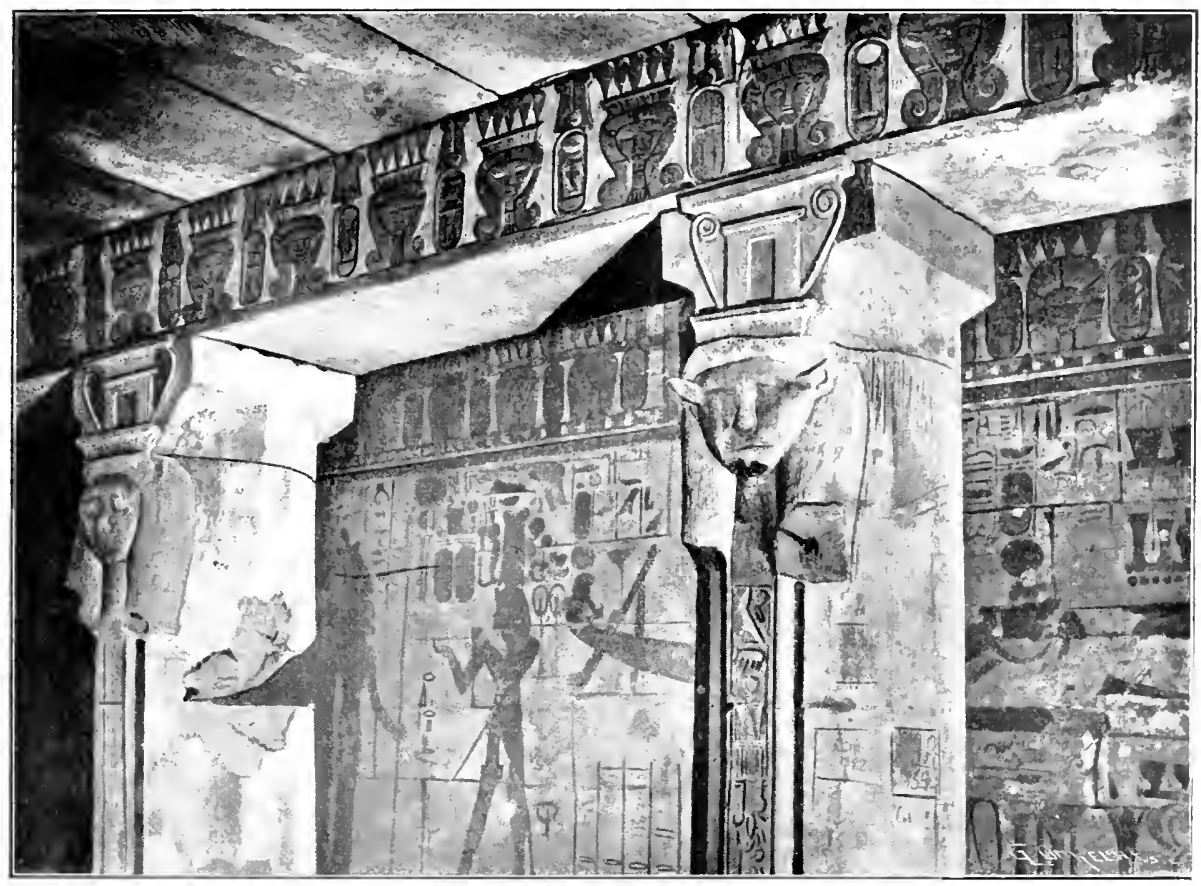

HATHOR PILLARS IN THE TEMPLE OF AMENOPHIS III AT EI-KAB 

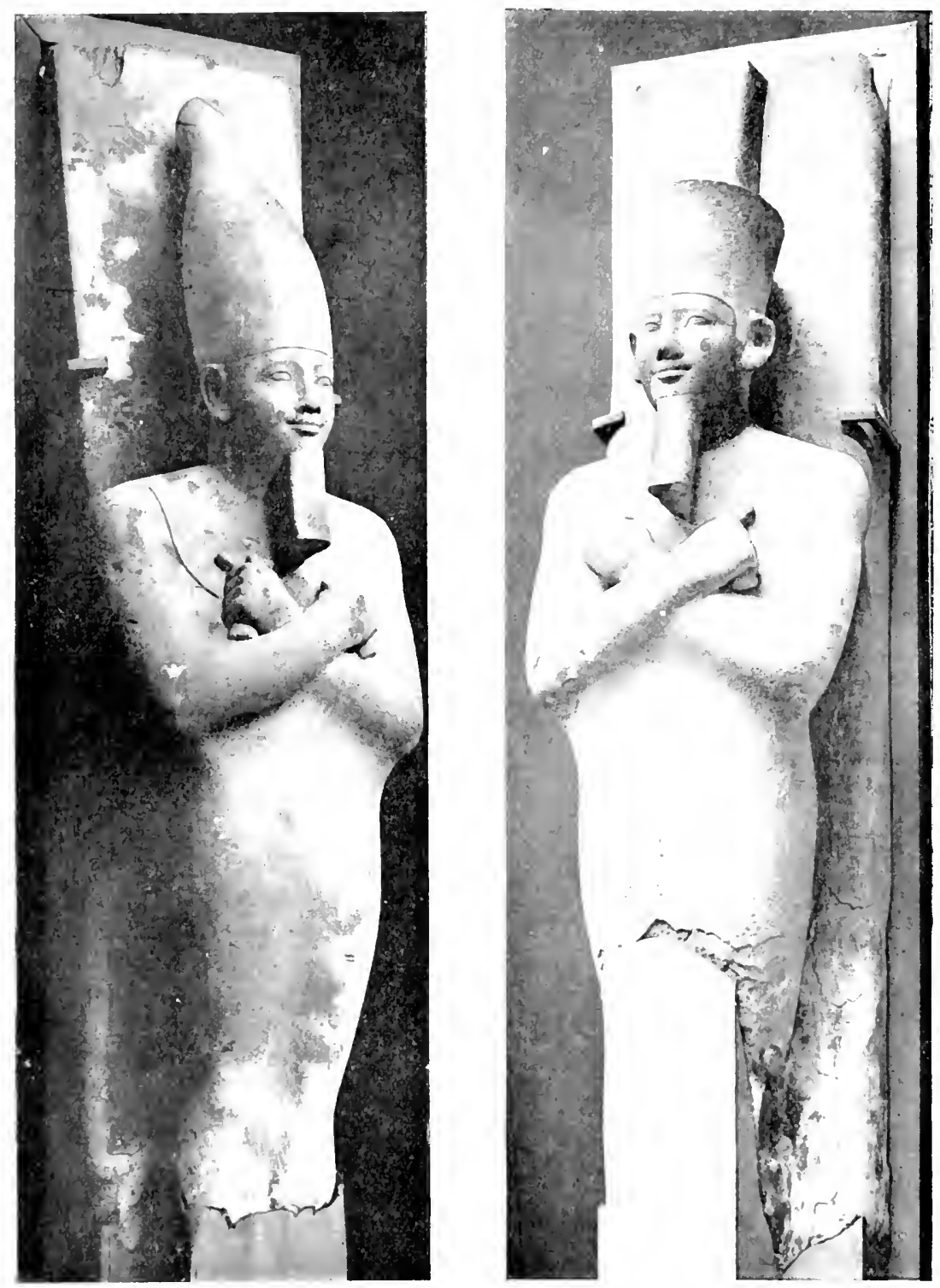

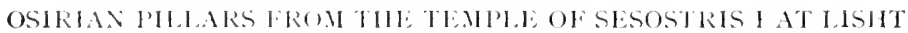

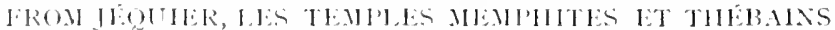


we ought to find a certain number of facettes, all the edges have been rubbed down in such a way as to form an even surface on which fine reliefs are engraved. These latter are interrupted four times by a long band of inscriptions running from top to bottom of the flat surfaces, which, with the abacus, are the survivals of the primitive pillar.

In all the examples which we have examined hitherto the faces of the polygonal pillar are plane surfaces, which would imply a prototype in stone, whilst the grooved pillars are derived from the imitation of wood. One might well ask, however, whether the fundamental form is not after all derived from wood and that the difficulty of transposition into stone led to the suppression of the grooving. This would be quite in harmony with the ancient hieroglyphic pictures of pillars alluded to in a previous chapter.

In rare instances we find stone pillars with grooves contemporary with pillars with flat faces. At Beni-Hasan, in the tomb of Ameni-Amenemhet I (XIIth dynasty) there is a hall with four grooved pillars with sixteen faces resting on broad round bases. (36) In the façade of the tomb of Chnumhetep IV another grooved pillar with sixteen faces is preserved almost intact. (37)

In the temple of Ramesses II, at Beit-el-Walî, (38) a curious pillar is to be found which seems to be a compromise between the two types: it has twenty-four faces, of which four are broad and flat and twenty narrow and grooved. The four flat faces are adorned each with a long line of inscriptions which separates the four groups of groovings. At the uppermost part, just before the abacus is reached, the different faces come to an end and give place to a smooth circular band. The same thing will be observed at the lower end.

Before leaving this point we have still to mention several cases in which masks of the goddess Hathor are attached to the upper end of the pillar; for instance, in the temple of Amenophis III at El Kab. (39) It will be remembered that in Hathor sanctuary at Deir-el-Bahari we called attention, in connection with decorative architecture, to the pillars surmounted by heads of the same goddess, and upon 
which were fixed two protuberances in imitation of breasts, as well as horns.

There now remains for our consideration a last type of pillar-the Osirian pillar. This name is applied to these pillars on account of the great royal effigies, portraying the king in the guise of the god Osiris, which stand affixed to rectangular or square pillars. Hölscher, in his architectural restoration of the temple of Khephren at Gizeh, (40) considers that from certain indications the deduction may be drawn that the court was adorned with a series of these pillars. The most ancient specimen preserved to us dates from the beginning of the Middle Empire, for the temple of Sesostris I at Lisht furnishes several instances. (4I) This type appears to have been reserved exclusively to the temples dedicated to the cult of the kings. Amongst the most celebrated examples it will suffice to cite the great colossi of Ramesses II at the Ramesseum. The king is represented standing upright, with arms crossed over the breast grasping the royal insignia-sceptre and flail-the body completely wrapped in a shroud, closely swathed, like the windingsheet of a mummy. Side by side with the traditional type, the temple of Medinet Habu shows a curious variant. (42) In the first court the pillars are flanked by great figures of the king, standing erect, clothed this time in the garments of the living : the legs are visible and detached, although placed together instead of following the usual attitude of the statues in which the left leg is generally advanced. At the side smaller figures represent members of the royal family.

We must not, however, compare these Osirian pillars to caryatides, for the human figure plays no architectural part : it does not uphold the superstructure, and is simply placed against a pillar which performs its function independently of the sculptured figure. It would seem that we have nothing but an artifice to replace the great royal statues which adorn other temples set up between the columns of the portico; for example, in the court of Ramesses II at Luxor.

In Ethiopian architecture the pillars are ornamented with colossal figures of the god Bes. (43) 


\section{BIBLIOGRAPHY.}

I. Borchardt, L., Das Grabdenkmal des Königs $S a^{\prime} h u-R e^{6}$. I. Der Bau, Leipzig, I9 10, pl. 5 .

2. Prisse d'Avennes, Histoire de l'Art égyptien, Paris, I 878, t. i., pl. 55.

3. Maspero, G., Les Temples immergés de la Nubie. Rapports relatifs à la consolidation des temples, Cairo, I9I I, pl. CLIX.

4. Mariette, A., Voyage dans la Haute Egypte, Cairo, 1878, t. ii., pl. 67.

5. Lepsius, R., Denkmäler, Part III, pl. 243.

6. Gauthier, H., Le Temple de Ouadi es-Sebouâ, Le Caire, I9 I 2, pl. LVIII.

7. Gauthier, H., Le Temple de Kalabchah, Cairo, I9I I, pl. LXIIa.

8. Naville, E., The Temple of Deir-el-Bahari, Part VI, London, Igo8, pl. CLXXIII.

9. Prisse d'Avennes, Histoire de l'Art égyptien, Parjs, i 878 , t. i., pl. $4^{8 .}$

Io. Maspero, G., Les Temples immergés de la Nubie. Rapports relatifs a la consolidation des temples, Cairo, I 9 I I, pls. CXVI and CXIV.

I I. Capart, J., Le Temple de Séti I'r, Bruxelles, I9 I 2, pl. VI.

12. Prisse d'Avennes, Histoire de l'Art égyptien, Paris, I 876, t. i., pl. 35.

13. Mariette, A., Voyage dans la Hante Egypte, Cairo, I878, t. ii., pl. 70.

I 4. Borchardt, L., Das Re-Heiligtum des Königs Ne-Woser-Re. I. Dar Bau, Berlin, I 905, figs. $49-50$, p. 55 .

I 5. Hölscher, U., Das Grabdenknal des Königs Chephren, Leipzig, I9I 2, pl. IX ; Jéquier, G., Les Temples memphites et thébains des origines à la fin de la XVIII dynastie, Paris, I920, pl. 4, n. I.

16. Lepsius, R., Denkmäler, Part I, pl. 90.

I 7. Capart, J., l'Art égyptier, t. ii., Bruxelles, I9 r r, pl. I49.

I 8. Ibid., pl. I93.

I 9. Mariette, A., Voyage dans la Haute Egypte, Cairo, i 878, t. ii., pl. 69.

20. Jéquier, G., Les Temples memphites et thébaines des origines à la fin de la XVIIIe dynastie, Paris, I920, pls. 3 and 4 .

21. Hölscher, U., Das Grabdenkmal des Königs Chephren, Leipzig, I 9 I 2 , fig. 26, p. 43 .

22. Maspero, G., Les Temples immergés de la Nubie. Rapports relatifs à la consolidation des temples, Cairo, I9I I, pl. CXXXIV.

23. Blackman, A. M., The Temple of Derr, Cairo, I9i 3, pl. XXVIIIa.

24. Prisse d'Avennes, Histoire de l'Art égyptien, Paris, I878, t. i., pl. I6; Jéquier, G., Les Temples memphites et thébains des origines à la fin de lo XVIIIe dynastie, Paris, I920, pl. 60 .

25. Davies, N. de G., The Rock Tombs of El Amarna, Part VI, London, I 908, pl. XXXVI.

26. Gauthier, H., Le Temple d'Amada, Cairo, i 9 I 3, pl. A and pl. I.

27. Prisse d'Avennes, Histoire de l'Art égyptien, Paris, I 878 , t. i., pl. I4.

28. Borchardt, L., Zur Baugeschichte des Amonstempels von Karnak, Leipzig, I905, P. 32 .

29. Prisse d'Avennes, Histoire de l'Art égyptien, Paris, r 878 , t. i., pl. 36. 30. Naville, E., The XIth Dynasty Temple at Deir-el-Bahari, Part II, London, I9ro, pl. XV. 
31. Davies, N. de G., The Mastaba of Ptahhetep and Akhethetep, Part II London, I $9 \circ \mathrm{I}$, pl. II.

32. Jéquier, G., Les Temples memphites et thébains des origines à la XVIII dynastie, Paris, I 920 , pl. 14, n. 2.

33. Newberry, P. E., Beni-Hasan, Part I, London, I 893, pl. XXII.

34. Naville, E., The Temple of Deir-el-Bahari, Part II, London, I872, pls. XXX-XXXI ; Jéquier, G., Les Temples memphites et thébains, Paris, I920, pls. 30-32; Karnak, ibid., pl. 53, n. I.

35. Caulfield, A. St. G., The Temple of the Kings at Abydos, London, I902, pl. XI ; Capart, J., Le Temple de Séti Ier, Brussels, I9I2, pl. VII.

36. Newberry, P. E., Beni-Hasan, Part I, London, I893, pls. III-VI.

37. Ibid., pl. XXXIX.

38. Prisse d'Avennes, Histoire de l'Art egyptien, Paris, 1878, t. i., pl. 42. 39. Tylor, J. J., Wall Drawings and Monuments of El Kab. The Temple of Amenhetep III, London, I898, frontispiece.

40. Hölscher, U., Das Grabdenkmal des Königs Chephren, Leipzig, I9I2, fig. 16, p. 28.

4I. Gautier, J. E., et G. Jéquier, Memoire sur les fouilles de Licht, Cairo, I902, fig. 38 , p. 39.

42. Prisse d'Avennes, Histoire de l'Art égyptien, Paris, I 878, t. i., pl. 44. 43. Lepsius, R., Denkmäler, Part V, pl. 6. 


\section{FUNDAMENTAL FORMS IN ARCHITECTURE-continued}

\section{The Column.}

$7 \mathrm{HE}$ most original element of Egyptian architecture is certainly the floral column, which imparts to the

1 ancient Egyptian monuments a character which is quite their own. Without entering into an inquiry as to why the Egyptians gave most of their columns a form borrowed from plant life, it will be sufficient for our purpose to examine the different types created by the architects and to analyse the forms as we find them.

The whole question has been involved in extraordinary confusion by different writers, and in turning the pages of the various manuals it is astonishing to note the uncertain and promiscuous terminology employed: the words "lotiform" and "papyriform" are applied to the same columns by different authors. The merit of having reduced this chaos to order and of having defined the characteristics which allow us to draw up hard and fast distinctions is due to Borchardt. (I) Starting with the analysis of the plants which served the Egyptians for models, he shows us how to discern without ambiguity what belongs to the lotus and to the papyrus respectively, and moreover we are shown by him how to identify in each case the particular species from which the forms have been copied.

Lotus. - Two different species of lotus are very frequently represented on the Egyptian monuments : Nymphea lotus, or the white lotus, and Nymphaa carulea, or the blue lotus. As to Nelumbium speciosum, or the red lotus, it does not 
make its appearance until we come down to the monuments of the latest period. The lotus has a round stem, and its sepals and petals are of equal length. In the white lotus they are rather broad and of a roundish form, whilst in the blue lotus they are narrower and longer, and lanceolate in form. The lotus flower is often represented either fully open or as just emerging from the bud, and these two stages in the growth of the flower have given rise to two types of lotiform columns: one with an open and the other with a closed capital. This may best be seen on the columns represented by paintings which portray architectural subjects. (2) An entablature rests, in one case, on the open calyx of a white lotus, and in the other case on a half-open bud of the blue lotus. At the upper end of the shaft the little buds, which bend outwards, are bound together with bands. The presence of these little flowers would seem to indicate that we are dealing with a compound column instead of a simple one. As a matter of fact, both types are met with : the simple column consisting of a single stem ending in a single flower, and the compound column, composed of a number of stems bound in a sheaf, and ending naturally in a number of flowers. On a bas-relief in the Berlin Museum (3) some attendants may be seen busying themselves with the beasts entrusted to their care. They are sheltered by a light shed supported by simple lotiform columns with closed capitals. It is evident that the column, which rests upon a slightly raised base, is composed of a single stem and a single flower. Beneath the flower there is no trace of bands or of smaller flowers. The whole effect is simply of a roof supported on a number of lotus flowers stuck into the earth. In a similar scene in the tomb of $\mathrm{Ti}$ (4) an awning is supported by a row of columns of the same type, but here the shaft is of three stems tied together at the top with bands which hold in the small flowers. It is fairly certain that here we have a compound lotiform column, ending really in several half-open flowers. Egyptian graphic conventions are enough to explain that it was considered sufficient to draw only one flower.

The oldest lotiform column found intact is in the Cairo 
Museum. (5) It comes from the mastaba of Ptah-Shepshes at Abusir, and dates from the Vth dynasty. It is a compound or fasciculated column composed of six stems and of as many half-open buds. Between the main stems, and passing under the bands, are several little lotus flowers, which, by the necessity of stoneworking, adhere to the mass of the capital.

It will be clearly seen that the petals and sepals of the flowers reach the same height, and that they just abut upon the slab which forms the abacus. No other examples of lotiform columns are known amongst the monuments of the Ancient Empire.

In the Middle Empire we meet the lotiform column again in the tombs of Beni-Hasan. The example in the tomb of Khety (No. I7) will enable us to analyse all the special features of this type. (6) The column rests on a wide circular base; the shaft is composed of four stems which taper markedly from the base towards the capital; the stems are exactly circular in section; upon the capital the four buds show the outlines of the sepals and of the petals, though less clearly than the Ancient Empire example ; the whole is more massive, and follows the natural forms less closely. The same may be said of the small intermediate flowers, which have become a simple wavy stem, as though the sculptor was not quite sure of what he had to do.

We are ignorant of the reason which prevented the lotiform column from playing a more favourite part in Egyptian architecture. It may almost be said to have disappeared completely after the Middle Empire, and it is not until Ptolemaic times that we meet with the lotus flower again in the composite capitals of the period. In the example found by Petrie at Memphis, (7) the abacus appears to be supported upon the tips of a group of closed buds; in the space left free by the buds are drawn open blue lotus flowers, and towards the lower part little lotus buds are grouped here and there; the bands which tie the whole bundle are brought down a little below the flowers in such a way as to expose part of the stems. As we shall see later on, this 
last detail is sufficient to $f x$ the date of this capital and to assign it to late times. Another capital, figured by Prisse, (8) displays a veritable bouquet of open lotus flowers arranged in two rows. The new position of the little flowers on the large ones is quite against the ancient use of them, between the principal stems.

Papyrus.-Two varieties of papyrus are frequently represented on Egyptian monuments : Cyperus papyrus and Papyrus alopecuroïdes.

Cyperus papyrus.-A fragment of painting from a hunting-scene in one of the Beni-Hasan tombs (9) gives us an instructive example of the two fundamental ways in which the Egyptians represented the Cyperus papyrus. Here we see a certain number of plants with their bells closed and of others with the flowers completely open. The flower is formed of several triangular sepals and a considerable amount of bloom which is fused into one mass, the sepals reaching about one-third of the height of the bloom. When the flower is completely open its general form is bell-shaped, which has caused the name "campaniform" to be applied sometimes to columns inspired by this model. When, on the other hand, the flower is still closed, its outline may easily be confounded with that of lotus buds which are just beginning to open. This will explain why the two have so often been confused, although the sepals afford the clearest means of distinguishing them : in the lotus they reach to the top of the flower; in the papyrus they stop at about one-third of the height.

A number of paintings and bas-reliefs of various periods represent the gathering of papyrus, which the Egyptians put to a multitude of different uses. The plants, when plucked, are tied in bundles. An example in the tomb of Puimre (10) will serve as a specimen. A man carries on his back a tightly tied bundle which at the lower end shows perceptible narrowing. It is evident that at one pull a plant has been uprooted with all its divergent stems, and that in tying it up tightly by a cord the characteristic bulge is produced quite naturally at the base of the bundle.

If we now turn to a column in the tomb of Ay at Tell- 

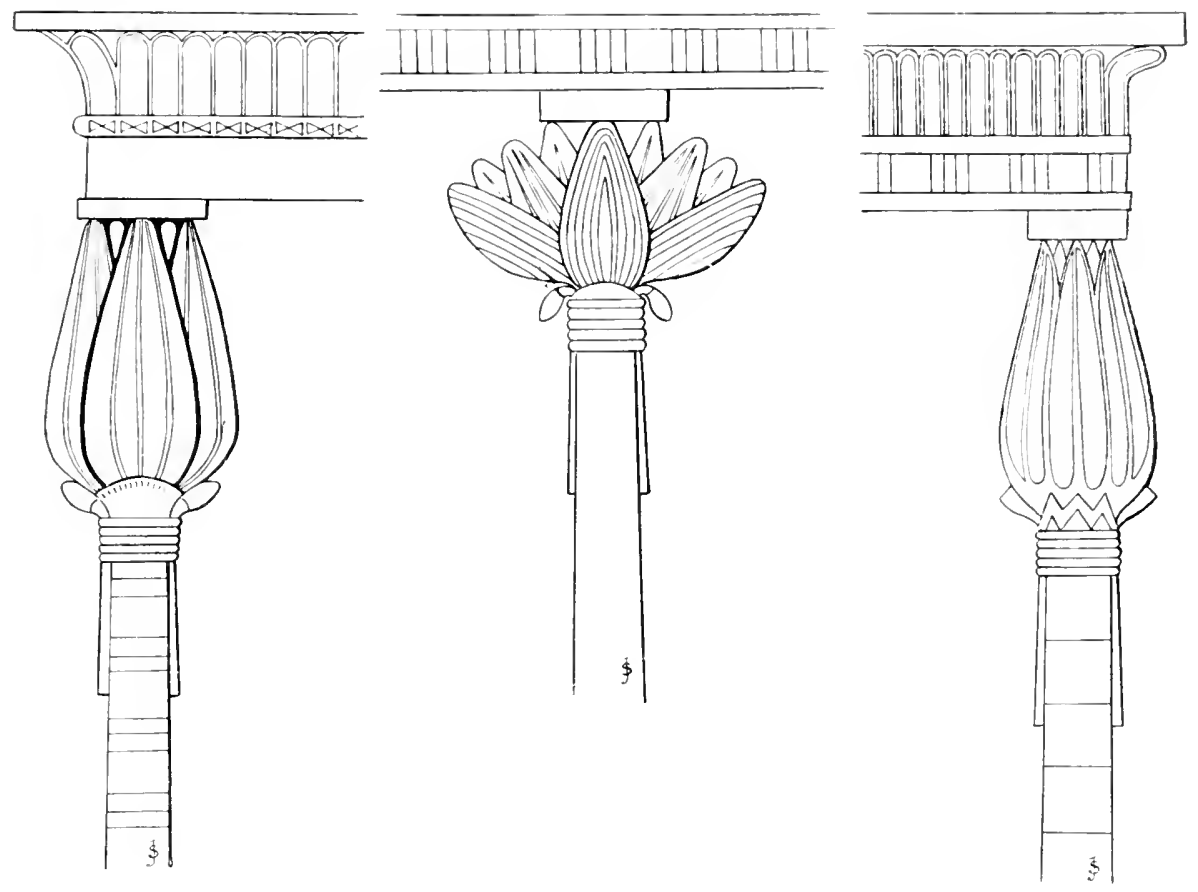


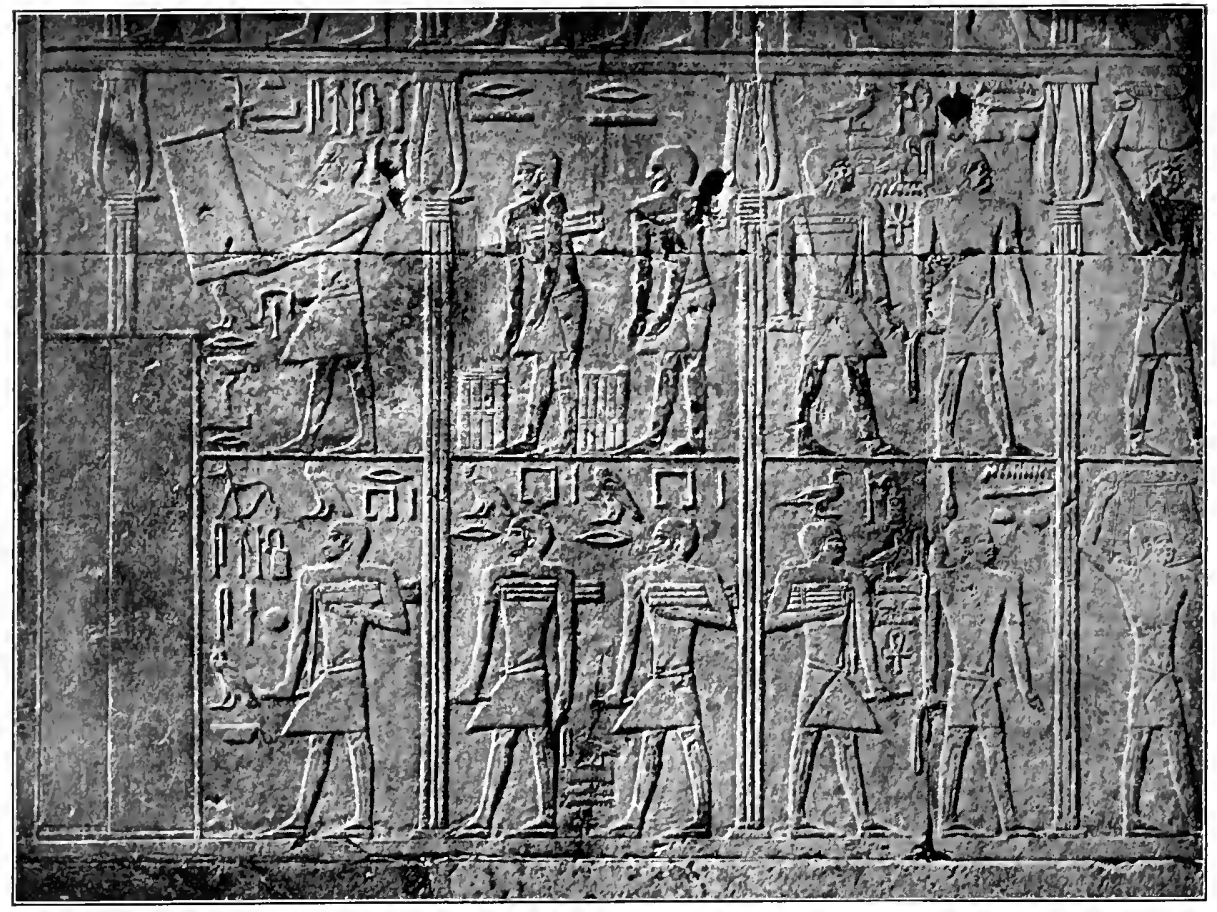

LOTIRUR COLUMNS IN AN ANCIENT DMIJRE REIEEF

IN THE TONH OI' TI 


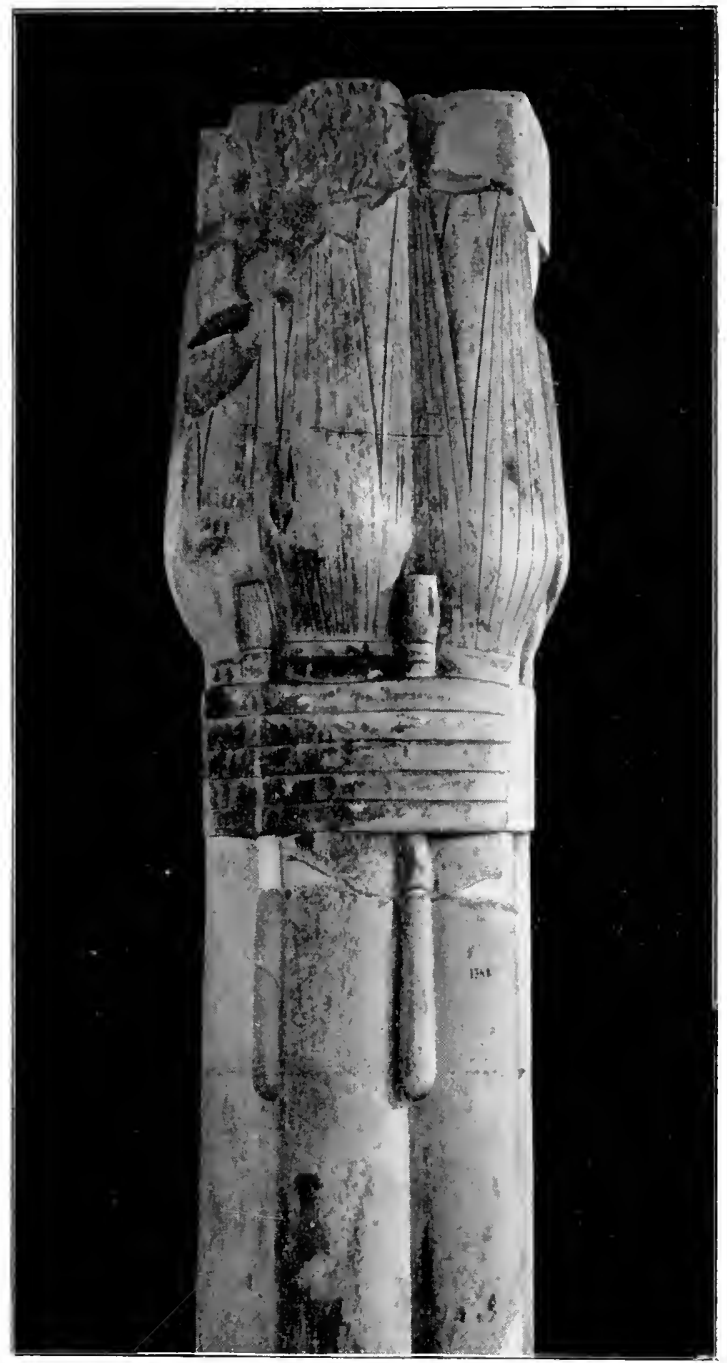

LOTIFORM COLUMN FROM THE MASTAB.I OF PTAH-SHEPSHES 


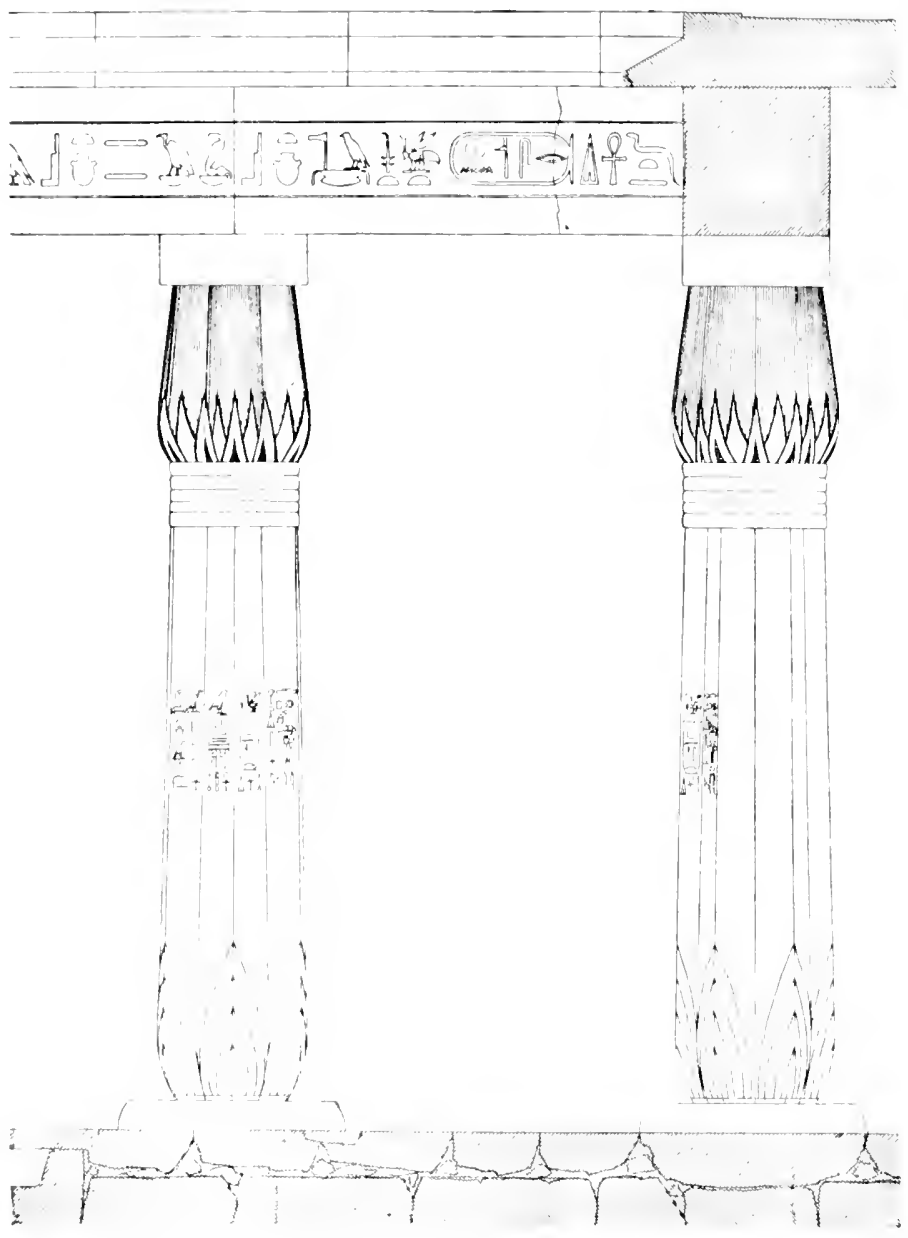

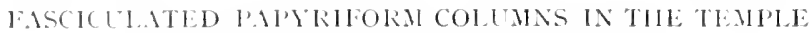
OI NELSERRE AFER BORCHARDT 
el-Amarna, (I I) it will at once be apparent how exactly the fasciculated or bunched papyriform column reproduces the general form of a clump of papyrus. The only important difference is that in imitation of what we have already noted in the case of the lotiform column, under the bands at the upper end were inserted a series of short stems tied in threes and which have their own tying-bands, and these are represented a little above the bands which hold the principal sheaf together. In this example the column is made up of a certain number of separate groups of stems. Each of these groups is usually treated as a single stem, and in this light we must now analyse the papyriform column as it is most commonly met with.

The fasciculated papyriform column rests on a circular base cut with a slight bevel. It normally consists of eight stems whose section, instead of being round as in the lotus, is sharply triangular, which also corresponds with the natural form of the stem. From the capital downwards the shaft enlarges down to a point near the base where it narrows down in the way whose origin we have just explained. The lower part of each of the stems is ornamented with a triangular decoration in imitation of the root leaves and leaflets at the foot of the plant. Above the bands is a number of closed blooms, one to each of the stems below, and likewise ornamented with the triangular device, this time in imitation of sepals. This decoration is broken by the bundles of little stems, each of which is fixed by bands of its own. All this involves a complex play of horizontal, vertical and transverse lines on the upper part of the column which is quite original. The papyriform columns just described really constitute the most characteristic order of Egyptian architecture.

Examples of all periods are extant, and afford the materials for tracing a progressive development. In the temple of Neuserré, of the Vth dynasty, two varieties already make their appearance : one, in the valley portico, (12) is of a slender, angulated and sinewy type; the other, which is met with in the upper temple court, (13) is of a heavier, rounder and more inflated type. Both types persist down 
to the New Empire, where the second is finally superseded. In the temple of Karnak, in the hall known as the botanic garden, (14) four columns of Tuthmosis III might well pass as elegant and slender specimens of classic papyriform. The great court or the hypostyle hall of Amenophis III at Luxor present the same type in profusion. (I 5) In this last case, however, the small subsidiary stems are not so sharply distinguished from the main stems : they form on the upper part, both above and below the bands, a smooth fillet on which the details are only just indicated by faint marks. The column is fasciculated or bunched from the base to the top, but it is encircled at three-quarter height by a smooth and continuous belt.

This concealment of original forms extends very rapidly to other parts of the column. In the tomb of Tutu at Tellel-Amarna, (I6) although the column shows all the elements of the sheaf at its upper end, the whole of the lower part is entirely masked by a smooth surface. It certainly might be supposed that the sculptor had left his work unfinished and that he had simply blocked out the shaft, were it not for the fact that the column, under this form-smooth from the base even to the top of the capital-becomes quite customary from the beginning of the XIXth dynasty. The columns in the hypostyle hall of Seti I at Abydos, (I 7) and those of the court of Ramesses II at Luxor, are typical examples. This concealment of forms has not, however, done away with the characteristic narrowing near the base which alone is sufficient to recall clearly what the original form really was. On the smooth surfaces thus obtained there was perfect freedom for the development of ornamentation, of inscriptions and even of bas-reliefs. Part of this ornamentation is related to the primitive form : thus near the base the triangular devices are maintained which recall the root-leaves; higher up, the intermediate stems are traced one beside the other, dividing the circumference of the column into a number of small rectangular surfaces which are distinguished from one another by being painted different colours. (18) This sector of vertical elements is cut off by the original large bands, whilst above, on the bulbous part 
of the capital, the groups of small stems are traced, separated by a pointed decoration which recalls the sepals of the flower. Sometimes, as in the hypostyle hall at Karnak, (19) the decoration proper to the origin of the forms is more and more encroached upon. The small stems have disappeared beneath a series of cartouches; royal titles are spread over the bands ; on the bulbous part, where the usual details are carved, they are at once obliterated by another series of royal cartouches. Indeed, had we no other columns preserved than those of this kind, it would be absolutely hopeless to attempt to discover that their origin was related to any kind of vegetal species whatever.

Hitherto we have dealt only with fasciculated papyriform columns with closed capitals, but there are also columns of the same type with open capitals.

Thanks to the numerous fragments which he found, Petrie was able to reconstitute an open-capitaled papyriform column from the palace of Amenophis IV at Tell-elAmarna. (20) Here the bundle of stems is tied by several bands arranged at different heights, the last of which-and this is a noteworthy point-is placed some little distance below the base of the flowers. The open flower is not a form which lends itself readily to grouping, for the extremity of each flower is contrariwise to that of its neighbour. It may be added that the Tell-el-Amarna example would appear to be unique.

From time to time, in the New Empire temples, large papyriform columns with open capitals are met with; the stems are fused together and united, and the capital appears as a single open flower-bell. We may instance the colonnade of Tut-Ankh-Amon at Luxor, (2 I) or the central nave of the hypostyle hall of the Ramesseum, (22) or, again, that of Karnak. (23) The columns show a slight narrowing towards the base and under the capital a series of bands ; these two elements bespeak the fact that in reality, although the column is simple, it is conceived as having been originally fasciculated. The details of the capital (24) would seem to show some intention of recalling the composite character of the whole, and on the surface of the great flower-bell is 
carved or painted a series of little stems, which in their turn end in open blooms.

We must now note a particular case of the use of papyriform columns with open capitals, and that is, although they appear to be generally reserved for the central naves of hypostyle halls, they are used in one of the porticoes of the first court of the temple of Medinet-Habu, (25) but there they are of a more squat and solid form.

The open-capitaled papyriform column continues to be used after the New Empire without undergoing any appreciable modification. It is employed, for example, in the portico of the Ethiopian King Taharka in the first court at Karnak, (26) or, again, in the hypostyle hall of the GræcoRoman temple at Kom-Ombo. In this last the slight contraction and the lance-leaf decoration at the base is just perceptible, sufficient to distinguish, even in the merest fragment, between the papyriform and lotiform types. The ruins of the Sudanese temple of Musanwarat-es-Sofra (27) have columns of a still more recent period, which might rank as the last development of the open papyriform type, although in this case they have been channelled in a manner which is manifestly due to the influence of Greek architecture.

Cyperus alopecuroides (28).-The distinction between this plant and Cyperus papyrus is clearly shown by the paintings on the pavement of the palace of Amenophis IV at Tell-elAmarna. (29) The profile of the flower is bounded by three long sepals between which the bloom is marked by a mass of colour which lies well below the ends of the sepals. This is just the reverse of what happens in the case of Cyperus papyrus. The capitals in the hypostyle hall of the temple of Esneh (30) give a clear example of how this variety of papyrus is turned to account in architecture. Here we have a composite capital of late period in which the floral decoration is set out in several levels.

Composite Floral Capitals.-Amongst the architectural paintings of the New Empire, the artists often painted little columns whose capitals are formed in a very strange manner. It would seem that one type of capital is blended with others 


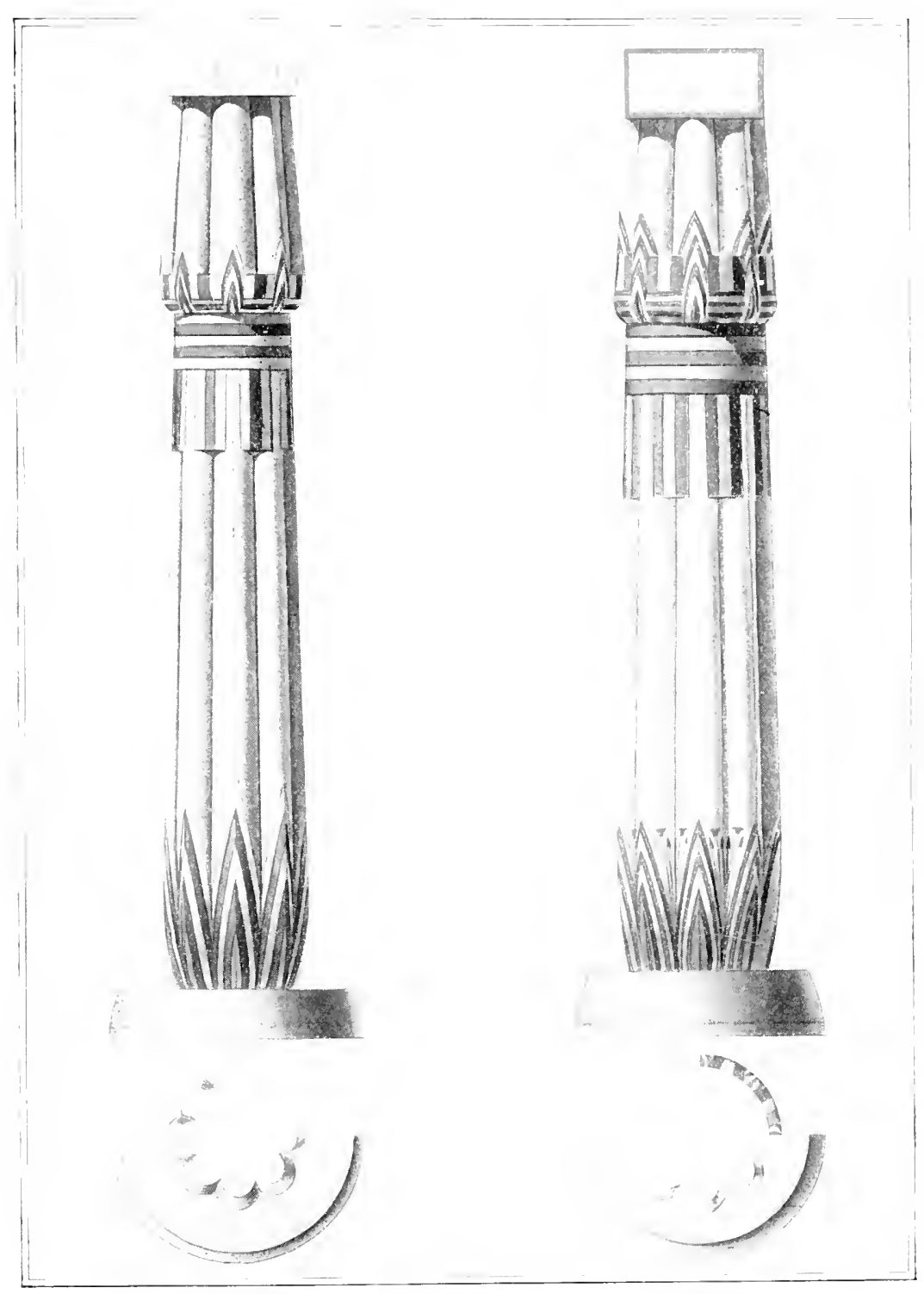

TYPICAL FASCICULATED PAPYRIFORI COLUMNS OF THE XVIIIT DINASTY 


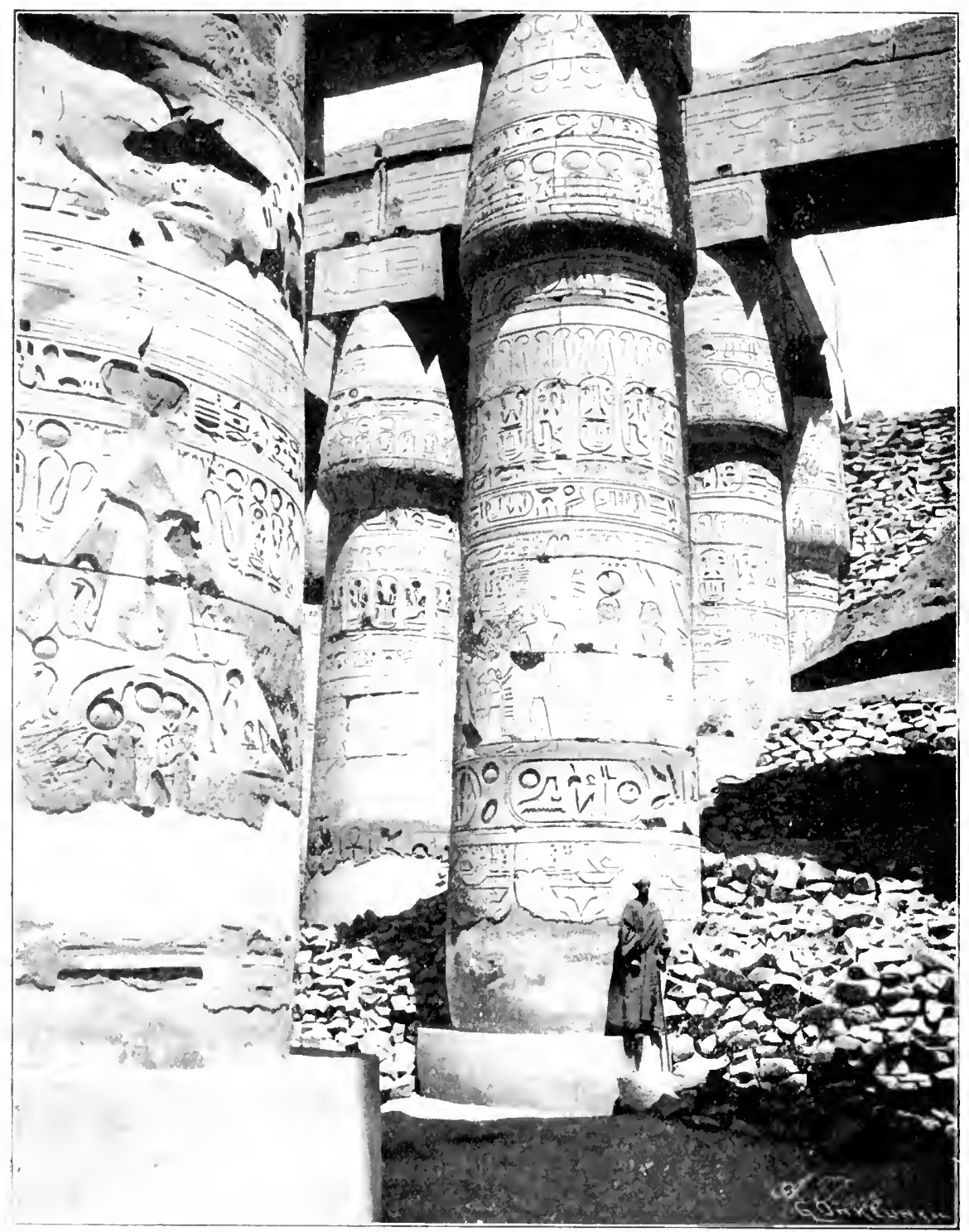


PLATE XIIII

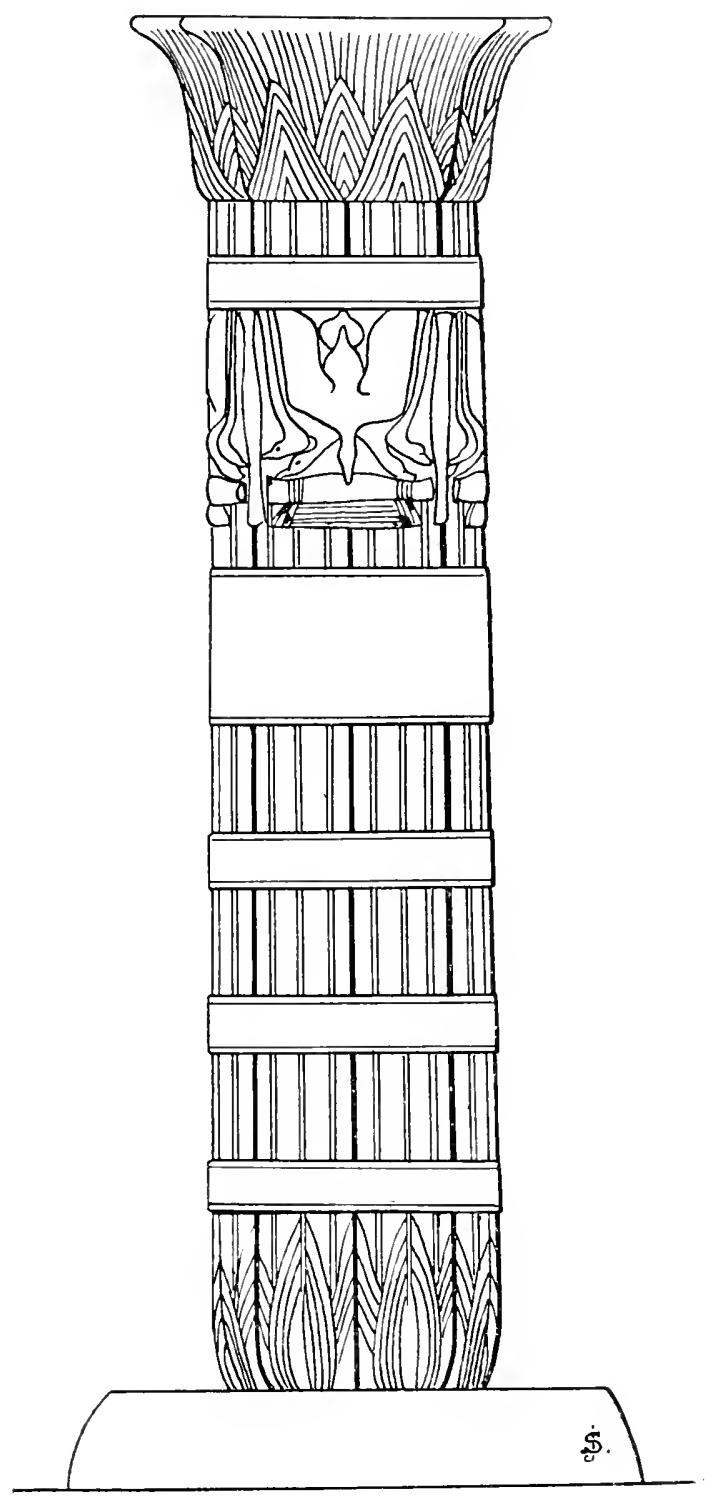




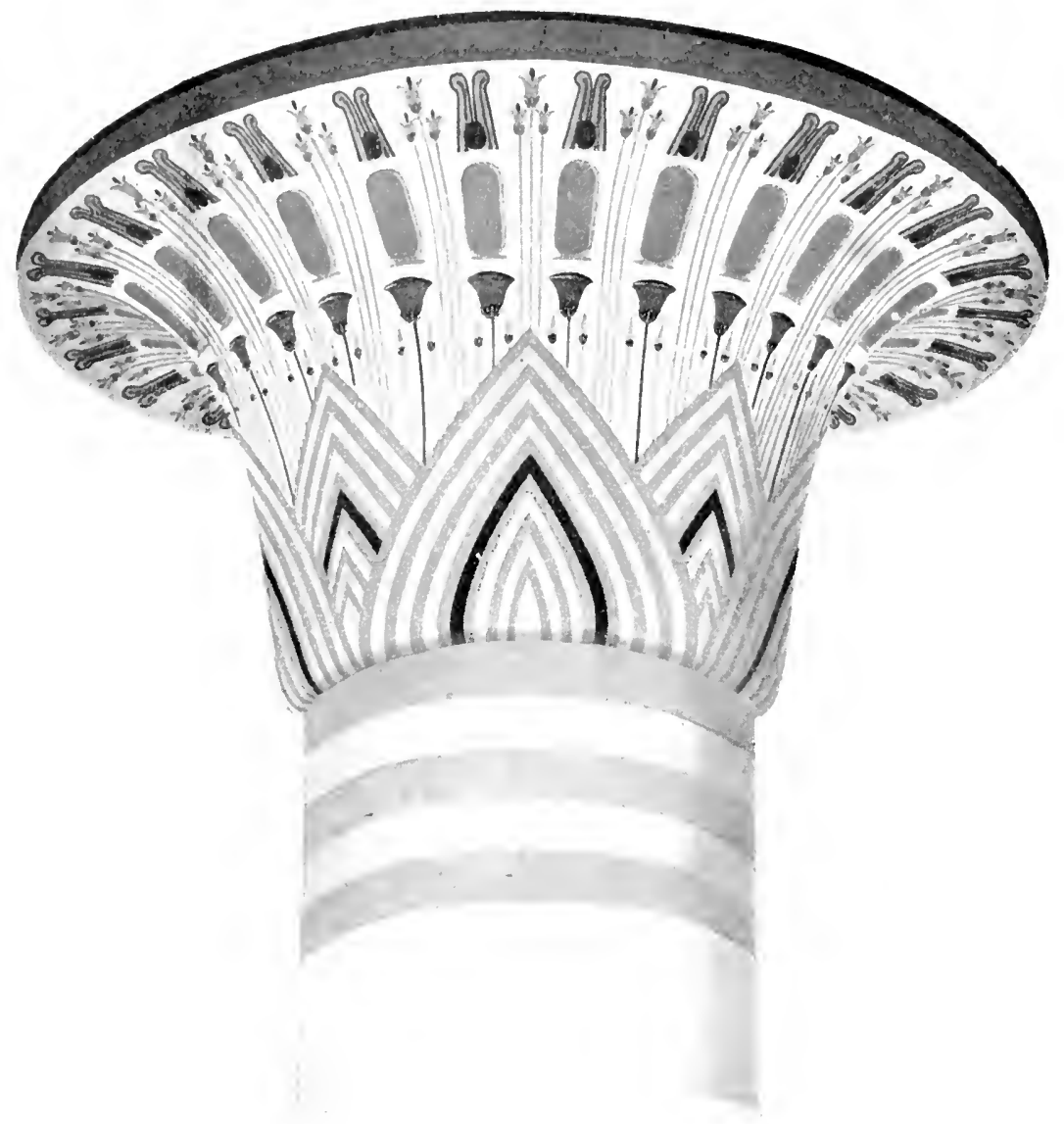

CAPITAL, OF COLUMN IN THE HYPOSTYLE HALL AT KARNAK 
of different types. (3I) It has long been asked to what reality this "dream architecture" could correspond. Here we may see a column with its closed papyriform capital surmounted by a half-open lotiform capital, then by a capital of the so-called "lily " type, and finally by an open papyriform capital decked with blooms. There we find a first capital, lotiform, a second of lilies, a third of open papyrus, and between the second and the third more lotus flowers which bend outwards. By means of certain graphic methods employed by the Egyptians we can obtain a simple interpretation of what appears to us an outrage on equilibrium. When the Egyptians wished to show what was spread out on a table or contained in a basket, being unable to display the different objects sufficiently clearly for their liking by proper perspective, they drew them carefully piled up one upon another above the upper edge of the table or receptacle. Here again, confronted with the problem of drawing a composite floral capital, the Egyptian draughtsman separates it into component elements, which he places one above the other. (32) The paintings of the New Empire thus first show us the use of capitals, which become the preponderating element in the buildings of late times. (33)

In theory it is postulated that the composite capital should presuppose a shaft made up of multiple stems, as we have just seen in the case of fasciculated columns, whether lotiform or papyriform. The remains of the portico of Medamût show two columns with composite capitals in which the bands stop at some distance below the capital proper and the stems of the flowers in the capital pass right down to the base. On the contrary, more often than not in buildings of late period the same thing occurs as happened when, in the XIXth dynasty, the forms of the papyriform columns were atrophied (see above, p. 122). The shafts are consequently absolutely smooth, or else constitute a compact mass the upper end of which terminates by the spreading of the bunched flowers whose multiple stems appear only above the bands.

One of the porticoes of the temple of Isis at Philæ presents quite a series of varieties of columns. (34) The bases no 
longer show any trace of contraction, even when the capital is decorated with papyrus flowers, but they all, however, bear the lanceolate decoration. The greater part of the shaft is covered with religious scenes and inscriptions. It will at once be noticed that all the capitals are different, whilst in earlier periods one type was usually employed for all the columns in a portico. In a single capital sometimes flowers and buds are arranged in three or four levels, and again both species of papyrus are sometimes combined; slight details of flowers or of fruits are sculptured on the sepals of the largest and most massive flowers. (35) There is a sort of passion to fill in as much as possible and to leave absolutely no surface undecorated. The fine simplicity of the oldest forms gives place to an exuberance of detail, just as the Renaissance ended by falling into Rococo.

Phonix dactylifera. - The palm column persisted throughout Egyptian history without appreciable modification, from the time of the example in the temple of Sahure (Vth dynasty) past the column of Tehuti-hetep at El-Bersheh (XIIth dynasty) and the capital in the palace of Amenophis IV (XVIIIth dynasty) down to the hypostyle hall at Edfu (Græco-Roman period). (36) A characteristic detail must be observed : (37) the bands which encircle the upper end of the shaft, arranged in the same manner as in the other orders, have the addition of a buckle, the significance of which has not been fully explained. It will be noted also that in late times, following the usual practice, the bands are sometimes lowered beneath the capital; in the free space thus obtained between the bands and the palms, a series of triangles is drawn, evidently imitating the ends of fallen leaves, as well as bunches of dates. In this case it is quite clear that the entire column is conceived as a palmtree, all of whose elements are copied exactly.

Lily, or Fleur-de-lis.-We have already encountered on one of the pillars of Tuthmosis III at Karnak, as well as on some of the composite capitals, the representation of a flower which has been called, for want of a more precise name, the fleur-de-lis, or lily. A wooden capital of this type, belong- 
ing to the Middle Empire, was discovered by Garstang at Beni-Hasan. (38) Architectural drawings, on the contrary, frequently depict the lily capital.

One author has suggested that we should see in this floral type an adaptation of the palm-tree. Without being quite convinced by the demonstation of Wurz, (39) it must be admitted that there is something of interest in this idea. It is certainly a fact that many of the characters of the socalled lily, as it is rendered, for example, in the Ptolemaic capitals, (40) recall the palm-leaf.

Columns with "Inverted Bells."-In the hypostyle hall called the Festival Hall of Tuthmosis III at Karnak, an abnormal type of column is to be found. (4I) The shaft is round, splays widely at its upper end, and on the broad surface of this splay rests what appears to be an open papyrus capital upside down. It has long been recognised that this type of column reproduces on a large scale the little columns which we found amongst the hieroglyphs with a tenon for jointing on its upper end. The column of Tuthmosis III might be compared with the upright of a light naos which is figured in the tomb of $\mathrm{Ti}$ (in the scene showing the transport of statuary). (42) This comparison, however, does not explain the origin of the form. It is probable that Schaefer is right in seeing here an imitation of a kind of club or sceptre. (43)

Hathor Columns. - The Hathor column consists of a round shaft surmounted by heads of the goddess Hathor, which are in turn surmounted by a kind of little shrine. This column is copied from a sacred instrument known as the sistrum. The ceiling of the hypostyle hall of the Dendereh temple is supported on several rows of columns of this type. (44)

Columns with Multiple Capitals.-The Egyptians also employed columns with strange combinations. Thus, in the temple called the Birth House, between the two pylons of the great temple of Isis at Philæ, there are floral columns with composite capitals surmounted with Hathor heads. (45) This freak might perhaps be explained by the fact that the colonnade in question served at once as the colonnade to the 
court of the temple of Isis (the portico on the other side of the court has foral columns with composite capitals) as well as to the little temple of the Birth, which demanded Hathor columns. The two capitals had been simply placed one on the other upon one and the same shaft. But a similar reason should have been discovered for other cases of such multiple capitals. (46)

Another variety shows raised above a floral capital a cubical stone on the faces of which are figures of the god Bes ; this is to be found, for instance, in the Birth-temple at Dendereh. (47)

In the famous kiosk at Philæ (48) the foral columns are surmounted by abaci of disproportionate size, and this is really because the shrine was never finished, and consequently the figures of the god Bes or the Hathor-masks have never been sculptured on the abaci.

To this series of combinations must be added a pillar in the temple of Ben-Naga in the Sudan; (49) the four faces were sculptured with figures of Bes, above which in each case was a Hathor-mask.

\section{BIBLIOGRAPHY.}

I. Borchardt, L., Die aegytitische Pflanzensäule, Berlin, r 897 ; see before: Joret, Charles, Le Papyrus et sa représentation sur les monuments de l'ancienne Egypte, in the Melanges Wahlund, 1896, pp. 273-80.

2. Prisse d'Avennes, Histoire de l'Art dgyptien, Paris, I878, t. i., pl. 20.

3. Klebs, L., Die Reliefs des alten Reiches, Heidelberg, 1915, fig. 53, p. 65 .

4. Marictte, A., Voyage dans la Haule Egypte, Cairo, i 878, t. i., pl. 10.

5. Jéquier, G., Les Temples memphites et thebains, Paris, 1920, pl. 7, n. 3 .

6. Newberry, P. E., Beni-Hasan, Part II, London, I 894, pl. X.

7. Petrie, W. M. F., The Palace of Apries (Memphis II), London, I909, pl. XVIII.

8. Prisse d'Avennes, Histoire de l'Art égyptien, Paris, 1 878, t. i., pl. 26.

9. Carter, H., M. W. Blackden, Percy Brown and Percy Buckman, BeniHasan, Part IV, London, 1900, pl. V.

ı. Wreszinski, W., Atlas zur altaegyptischen Kulturgeschichte, Leipzig, 1914, pl. 30.

II. Davies, N. de G., The Rock Tombs of El Amarna, Part VI, London, 1908, pl. XXXVII. 


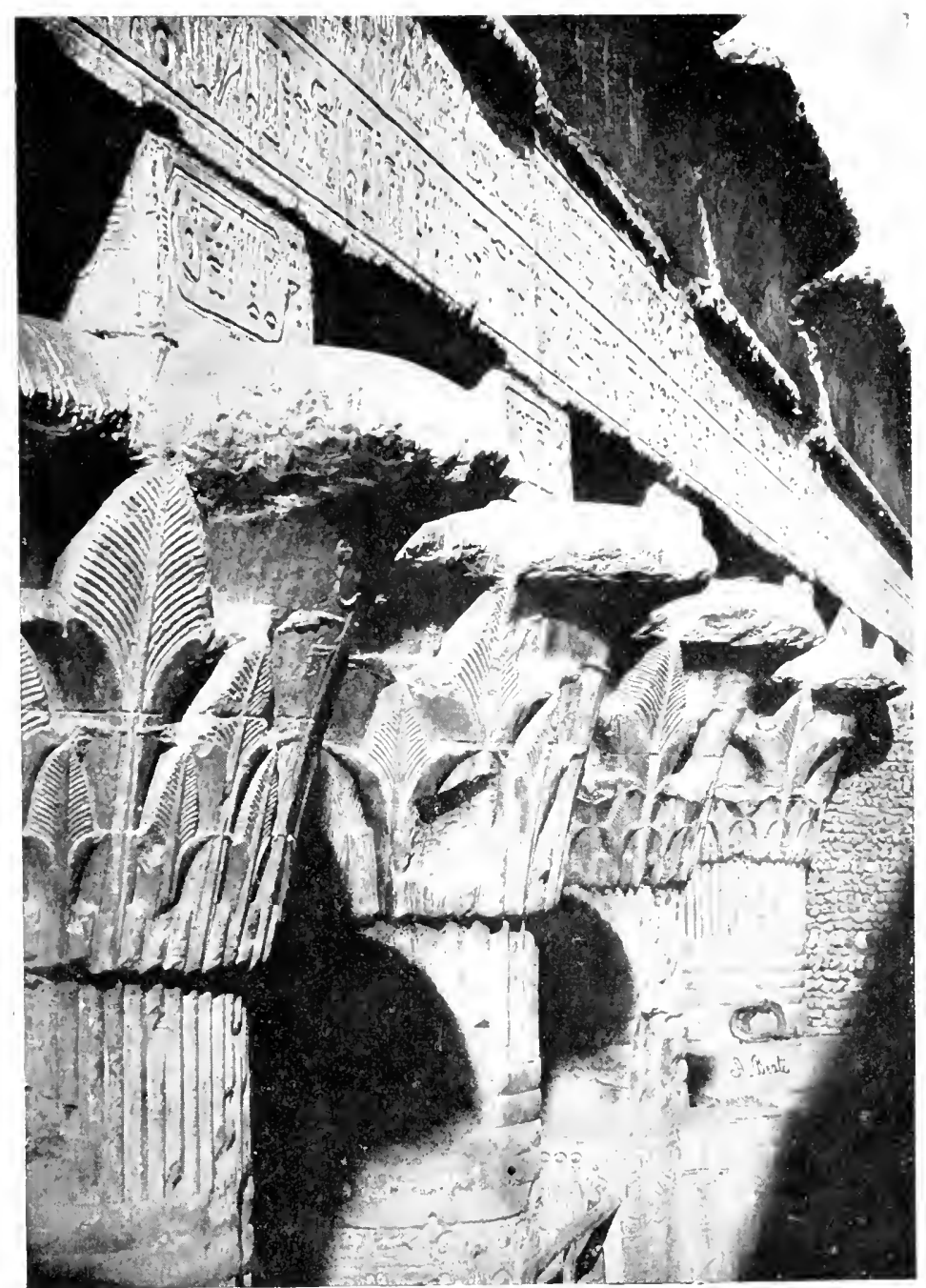




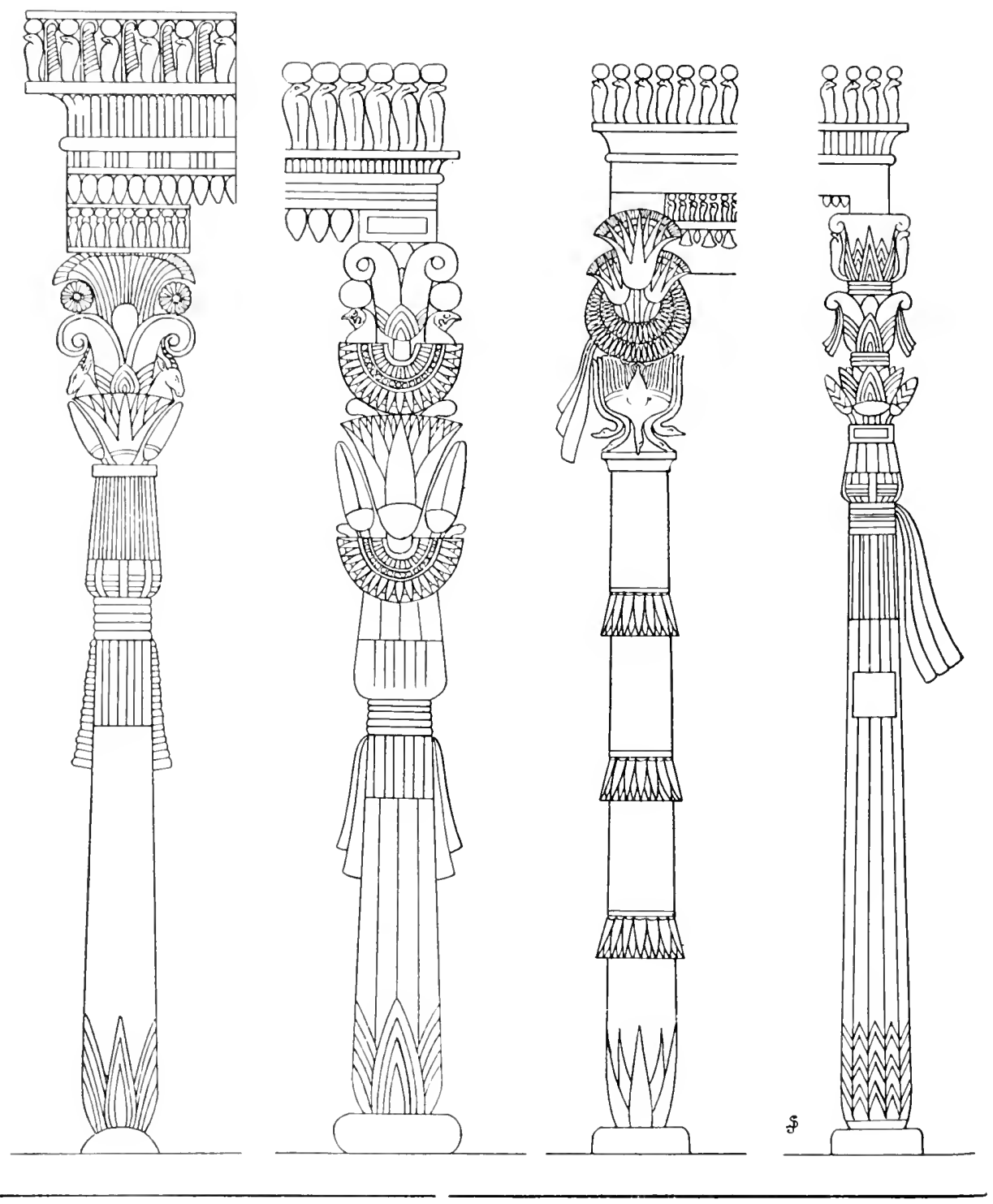




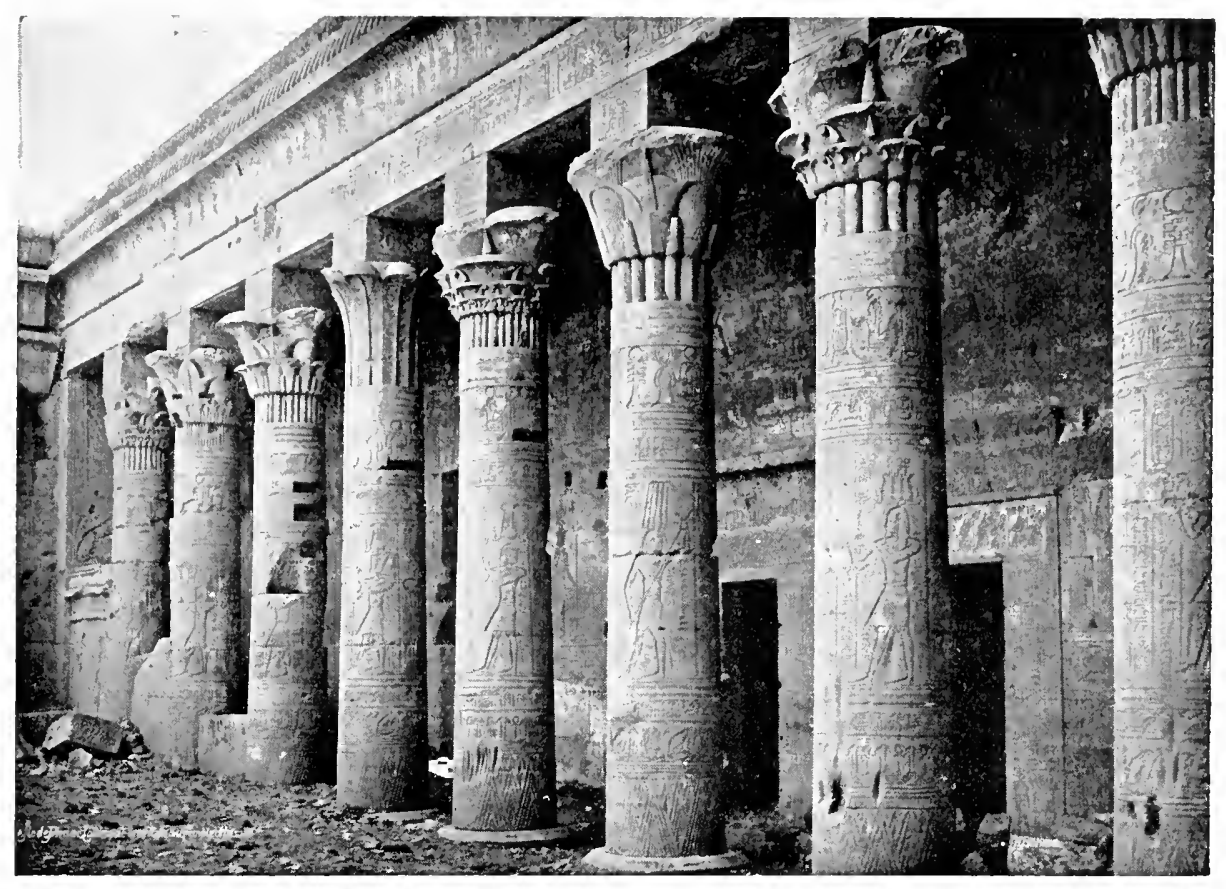

PORTICO OF THE TEMPLE OF ISIS AT PHILA 


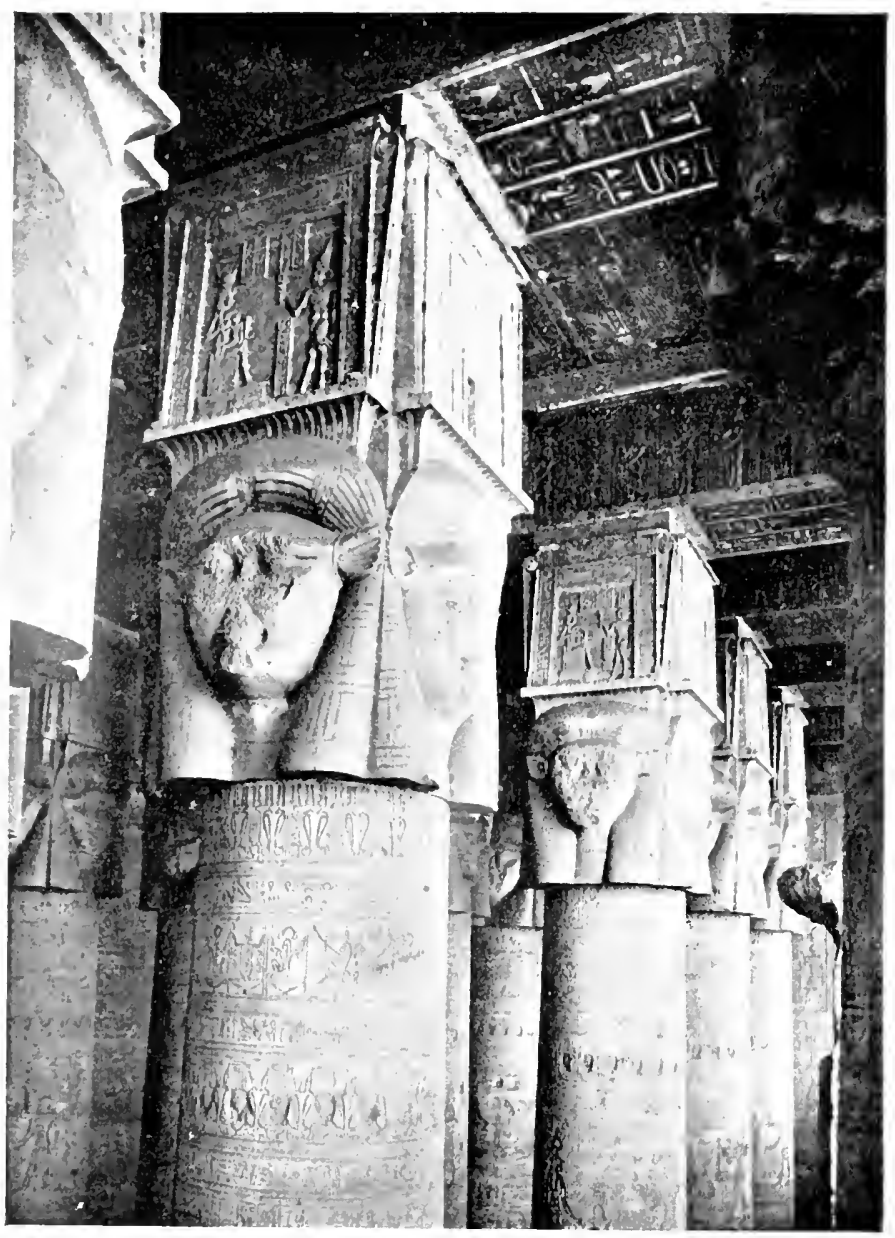

HYOSTYLE HALL OF THE DENDERA TEMPLE 


\section{FORMS IN ARCHITECTURE}

12. Borchardt, L., Das Grabdenkmal des Königs Ne-User-Re, Leipzig, I 907 , pl. 3 .

13. Ibid., pl. I3.

14. Mariette, A., Voyage dans la Haute Egypte, Cairo, I 878 , t. ii., pl. 47.

15. Jéquier, G., Les Temples memphites et thébains, Paris, 1920, pls. $65-70$.

16. Davies, N. de G., The Rock Tombs of El Amarna, Part VI, London, I908, pls. XXXV-XXXVI.

17. Capart, J., Le Temple de Séti Ier, Brussels, 19I2, pl. VI.

18. Lepsius, R., Denkmäler, Part I, pl. 90.

19. Béchard, and A. Palmiéri, L'Egypte et le Nubie, Paris, I887, pls. LXXXV-LXXXVIII.

20. Petrie, W. M. F., Tell-el-Amarna, London, 1894, pl. VII.

21. Jéquier, G., Les Temples memphites et thébains, Paris, 1920, pls. 62-64.

22. Lepsius, R., Denkmäler, Part I, pl. 90.

23. Ibid., pl. 80 . and 43 .

24. Prisse d'Avennes, Histoire de l'Art égyptien, Paris, I 878 , t. i., pls. 23

25. Hölscher, U., Das hohe Tor von Medinet Habu, Leipzig, I 9 I o, fig. 44, p. 49 .

26. Mariette, A., Voyage dans lo Haute Egypte, Cairo, 1878, t. ii., pl. 4 I.

27. Lepsius, R., Denkmäler, Part I, pl. 1396.

28. Borchardt, L., Die Cyperussäule, in the Zeitschrift für ägyptische Sprache t. xl., 1902-3, pp. 36-49.

29. Petrie, W. M. F., Tell-el-Amarna, London, I 894 , pl. III, n. 3 .

30. Mariette, A., Voyage dans la Haute Egypte, Cairo, 1878, t. ii., pl. 66.

31. Prisse d'Avennes, Histoire de l'Art égyptien, Paris, 1878, t. i, pls. 17-19.

32. But see Petrie, W. M. F., Tell-el-Amarna, London, 1984, pl. IX.

33. Köster, A., Die ägyptische PRanzensäule der Spätzeit, in the Recueil de travaux relatifs à la philologie et à "archéologie égyptiennes et assyriennes t. 25, 1903, pp. 86-1 19.

34. Mariette, A., Voyage dans la Haute Egypte, Cairo, I878, t. ii., pl. 82 .

35. Prisse d'Avennes, Histoire de l'Art égyptien, Paris, I878, t. i, pls. 58-61.

36. See Chapter IV, p. 67-8.

37. Prisse d'Avennes, Histoire de l'Art égytien, Paris, 1878, t. i., pl. 27.

38. Garstang, J., The Burial Customs of Ancient Egypt, London, 1907, fig. 139 , p. 141 .

39. Wurz, R., Spirale urd Volute, vol. i., Munich, I914, See fig. Io6, p. 48 .

40. Prisse d'Avennes, Histoire de l'Art égyptien, Paris, t. i., pl. 25.

4I. Jéquier, G., Les Temples memphites et thébains, Paris, 1920, pl. 50.

42. Steindorff, G., Das Grab des Ti, Leipzig, 19 13, pl. 70.

43. Puchstein, O., Die Ionische Säule, Leipzig, I907, p. 29.

44. Mariette, A., Voyage dans la Haute Egypte, Cairo, 1878, t. i., pl. 35 ; Wilkinson, G., The Architecture of Ancient Egypt, London, 1850, pl. XIII.

45. Béchard and A. Palmiéri, L'Egypte et la Nubie, Paris, I887, pl. CXXVII. 
46. See for an example the Temple of Nectanebo at Philx, in Prisse d'Avennes, Histoire de l'Art égyptien, Paris, 1878, t. i,, pl. 47.

47. Wilkinson, G., The Architecture of Ancient Egypt, London, I850, pl. XIII.

48. Lyons, H. G., A Report on the Island of and Temples of Phila, Cairo, 1 896, pls. 1 7-19.

49. Lepsius, R., Denkmäler, Part I, pl. I 392. 
CONCERNING COLUMNS AND THE TRANSPOSITION OF THE FORMS PROPER TO ONE MATERIAL INTO ANOTHER

$\mathrm{N}$ the previous chapter we studied Egyptian columns, and particularly floral columns, from the point of view I of their forms. We have now to investigate the considerations which led the Egyptians to choose for their architectural supports one form rather than another.

There is a preliminary point which must be cleared up forthwith. Are we entitled to say in general terms that the Egyptian column, and particularly the floral column, considered in the light of its forms, plays primarily a constructive part? In other words : is the form of the column adapted to its supporting function, and are the different elements of which it is composed more or less directly connected with this architectural end? Borchardt(I) replies to the question in these words: "The Egyptian floral column owes its origin solely to a decorative idea. . . . There is absolutely no expression therein of the idea of construction or of supporting." This theory has been disputed, and some writers have categorically affirmed that the floral column consisted of an internal core which was simply enveloped with the plants. (2) In his rejoinder Borchardt (3) insists and declares that " the Egyptian considered his floral columns as standing up free and that he consequently adorned them." What the German archæologist affirms amounts to this : he credits the Egyptians with the idea of setting up in their buildings a series of decorative elements which play the accessory constructive 
part of architectural supports. This point of view has some confirmation in the fact noted in a previous chapter, namely, that the Egyptian ceilings were ornamented with stars and with birds in flight. The Egyptian, raising his eyes in the hypostyle hall of a temple, could almost forget that his view was limited by a series of great slabs resting on the upper ends of the columns. But why, then, even if this theory be admitted, should the forms we have just analysed be chosen : floral columns, Hathor columns, and columns the shape of sceptres or clubs?

In order to answer this question, it will be interesting to examine a certain number of objects which play an important part in Egyptian cult and which belong to the series of ensigns which occur in the religious history of many countries. (4)

The best-known sacred object which stands solidly on the ground and rises towards the sky is the obelisk. (5) Obelisks usually occur in pairs : they were set up on either side of the doorways of temples, or, at times, even of tombs. (6) In the Ancient Empire these were of very small proportions. An important part was played by obelisks in the solar temples. For the Middle Empire we may instance the obelisk of Sesostris in the temple of Heliopolis; and for the New Empire we might cite the two obelisks at Luxor and the group of obelisks of Tuthmosis I, Hatshepsut and Tuthmosis III which stands before the granite sanctuary at Karnak.

Obelisks are not mere ornaments; they were considered as divinities " of flesh and bone" who needed food offerings which the religious texts meticulously prescribed. The erection of an obelisk constituted a cult ceremony of which representations may be found in the bas-reliefs of the temples.

If the obelisk by its large dimensions has attracted general attention, the same cannot be said of the whole series of staves, standards or sceptres figured amongst the scenes in the temple of Seti I at Abydos, to mention but one example. (7) We may see there a staff surmounted by a head decked in an enormous wig. The sacred staff is held 
upright by two little royal figures in a kneeling posture. It is the fetish of the god Osiris : the king, assisted by a priestess who impersonates the goddess Isis, is in the act of anointing the forehead of the image. At the side is an ensign which recalls those of primitive times; it supports an ibis, and is likewise supported by two small figures of the king. A little farther on, the king makes homage before a great sceptre which is connected, as the text tells us, with the god Thoth. Beside this, the figure of a falcon is set up on a raised perch; these two emblems are supported each by a kneeling figure of the king. A little farther on again, the king offers fillets or bandages to the emblem called the dad or did $\hat{u}$, which is dressed in a skirt; in the following scene the king, assisted by a priestess who impersonates Isis, performs the ceremony known in the texts as "raising the Dad."

Upon a square pillar from the tomb of a high-priest of Ptah in the Florence Museum, (8) on one of the faces may be seen the deceased carrying on his shoulders the dad or did $\hat{u}$. Upon another face he advances holding in his hand a wand, the end of which, high above his head, terminates with the head of a lioness surmounted by the solar disk.

One can now appreciate how it was that Schaefer could recognise in the curious columns of the Festival Hall of Tuthmosis III at Karnak gigantic sceptres or clubs. One is bound to admit also that in the pillars at Leiden, (9) which bear on one of their faces the picture of the didî, the dominating idea is not to decorate an architectural element, but rather to represent a sacred object.

A bas-relief in the Cairo Museum affords a particularly interesting case. (10) This time the staff is surmounted by a characteristic Hathor head wearing a complicated symbolic head-dress, made up of horns, the solar disk, plumes and urei. Here also, as in the Abydos sanctuary, two small figures of the king support the sacred emblem. Here again is the form of the magical instrument, the sistrum, which the queens or princesses brandished during the cult ceremonies. (II) The sistrum borrows its general form from the principal fetish of the goddess Hathor under the form 
of the staff which we have just examined. When we meet with a column which exactly copies the shape of the sistrum, as at Sedeinga (XVIIIth dynasty)(12) or at Dendereh (Græco-Roman age), we can affirm without hesitation that the Hathor column has no other pretension than to be an exact copy of a religious object, for the architects could easily adapt the emblem in this way. On the Hathor pillar at Deir-el-Medineh (I 3) it was considered sufficient simply to draw the sistrum just as the did $\hat{u}$ was drawn on the face of the pillar as we saw a little while ago.

It is probable that to the Hathor emblems are related the curious pilasters which are sculptured on each side of the entrance-door of the tomb of Ramesses III at Thebes, (I 4) the equivalent of which has not been found in architecture. Here the staff is surmounted simply by a cow's head, which, as is well known, is one of the principal forms of the goddess Hathor.

From what has been said it follows that many of the Egyptian columns probably imitate cult-emblems stuck in the ground and standing free. Is it not possible to discover something of the same kind in the case of the largest class of Egyptian columns; that is to say, the floral columns? Can we not find among the religious or funerary scenes an object which will recall in its general aspect the vegetal forms of the columns?

Let us revert to a scene in the tomb of Amenophis IV to which reference has already been made. (I 5) We witness in one of the bas-reliefs the episode of the death of Princess Maket-Aten : a statue of the dead girl is placed within a shrine the canopy of which is supported on floral columns. Before the statue itself is set up a large bouquet, the elements of which are arranged in layers, and which reaches to the height of the head of the statue. We can immediately perceive the analogy which the little columns of the shrine bear to the bouquet. In a processional scene in the temple of Ramesses II at Luxor or at Abydos (I6) these are bearers carrying similar bouquets. We find one placed beside the sacred barque in the sanctuary of the temple of Derr ; (I7) in the basement of the sanctuary at Kalabsheh (I8) the 
Nile figures are accompanied in each case by a large bouquet fixed in the ground. Two examples noted by Prisse d'Avennes (I9) show us in detail how these large bouquets are made up. On the upper stems of papyrus plants flowers of different kinds are attached and grouped in successive layers.

From the examination of these monuments it is clear that the bouquets play a part in Egyptian cult and that they form part of the customary offerings. But we may go further even than that. In the bas-relief of the tomb of Amenophis IV which portrays the sunrise is depicted a view of the temple of Tell-el-Amarna. (20) Before the façade, priests are seen in the very act of fixing bouquets of this kind in the ground in regular rows.

Bearing this in mind, we shall not be surprised to find in front of the façades of certain temples isolated floral columns for the architectural purpose of which we may search in vain. This is the case, for example, before the pylon of the late temple of Medinet Habu, where columns fulfil almost the same function as obelisks. (2r). The Theban temple of $\mathrm{Ptah}$ gives us another instance, where there are four floral columns in front of the pylon set in two rows and joined by a low wall. (22)

It remains to be shown that the Egyptians conceived the rather curious idea of using these floral groups as an architectural element for the support of a roof. In proof of this fact we may examine the bas-relief in the Berlin Museum which portrays a funerary episode of the highpriest of Ptah, in which we observe a number of small funerary tents containing provisions. (23) The supports from which hangs the matting which makes up the shrine itself are in the form of bouquets. In front of one of these tents which is in course of erection a man advances bearing in his arms several similar bouquets.

If this series of deductions be admitted, it will be recognised that there is no ground for solving the problem of the floral column otherwise than that of other forms of column : we can, moreover, recognise in it the use of cult objects set up in the ground, which quite definitely precludes any 
real search on the part of the architects for a decorative motive.

These large tapering bouquets necessarily underwent modification when they had to be adapted for architectural building, properly so-called. And this brings us into contact with a most important question in the study of Egyptian art : the problem of transposing a form of one material into another, and particularly the copying of objects of fragile material in durable material. This transition manifestly cannot be carried out without modifications and simplifications. And further, we have already seen that in architectural drawings certain kinds of floral columns are shown which have not been found in stone, the lotiform column with an open capital for example. When the transposition was to be made the strangest means were employed : the pillar of a VIth dynasty tomb at Zawiet-elMaietin is virtually an architectural monstrosity. (24) There we see a lotiform column with an open capital carefully sculptured in relief, which shows that the architect was obliged to have recourse to this almost childish subterfuge in order to remain true to a form which he had no idea how to render in stone.

The problem which has confronted the architects of different ages has been rather that of copying into stone forms already existing in light structures than of combining new types. Floral columns with a wealth of detail in which stucco has played its part have existed from the Ancient Empire times, as certain remains discovered at Abusir show. (25) Drawings also represent floral columns from the time of the IVth dynasty, whilst the Vth dynasty temples show us for the first time the use of stone for this purpose. We have likewise seen that columns with composite capitals are represented in drawings of the New Empire, although they are not known in stone until, at the earliest, during the Saite period.

The form of brick arches copied in stone affords a still further example which may appropriately be quoted here. (26) From the beginning of the Ist dynasty the Egyptians built brick arches with keystones. When in the stone-built 
PLATE XLIX

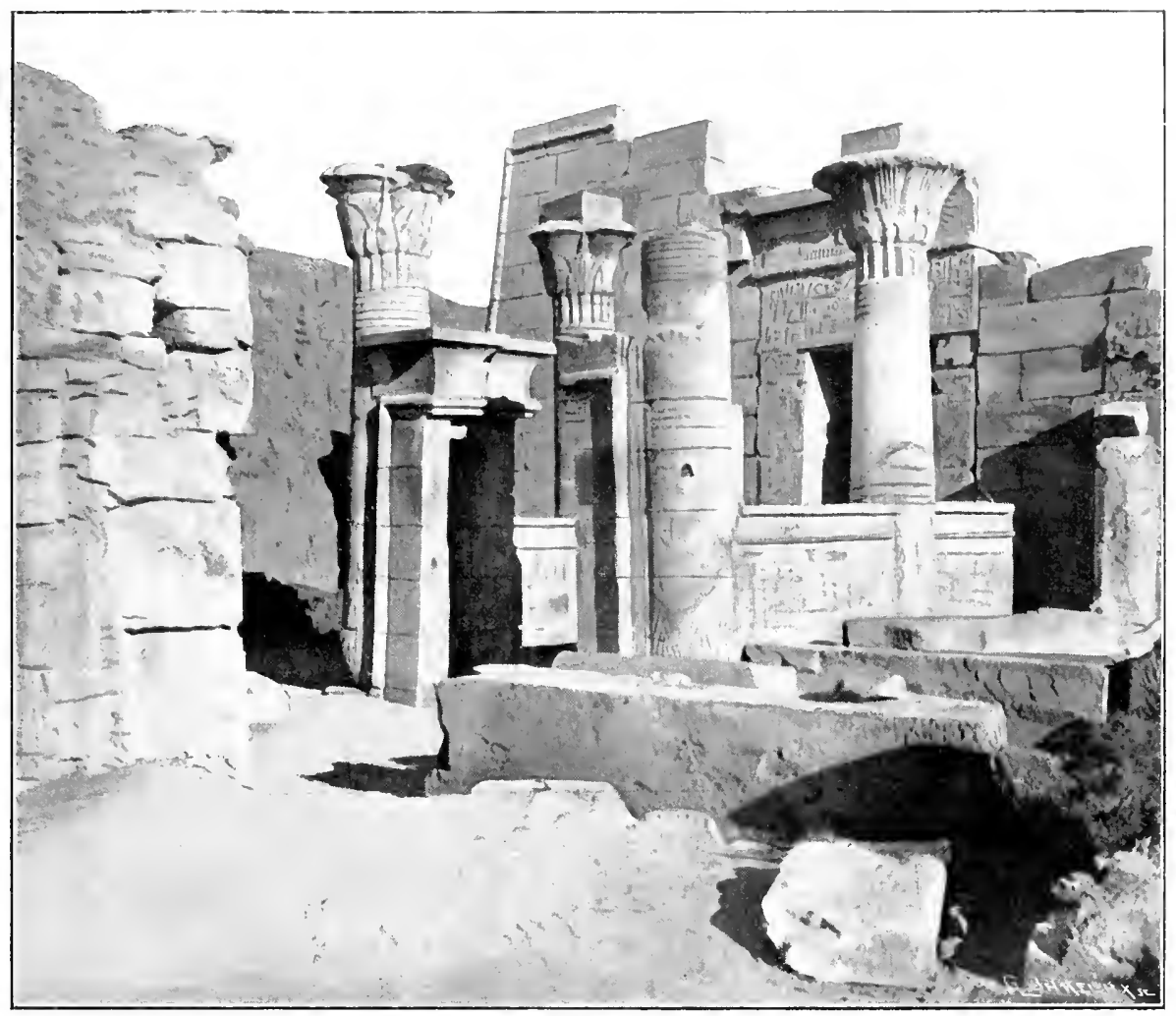




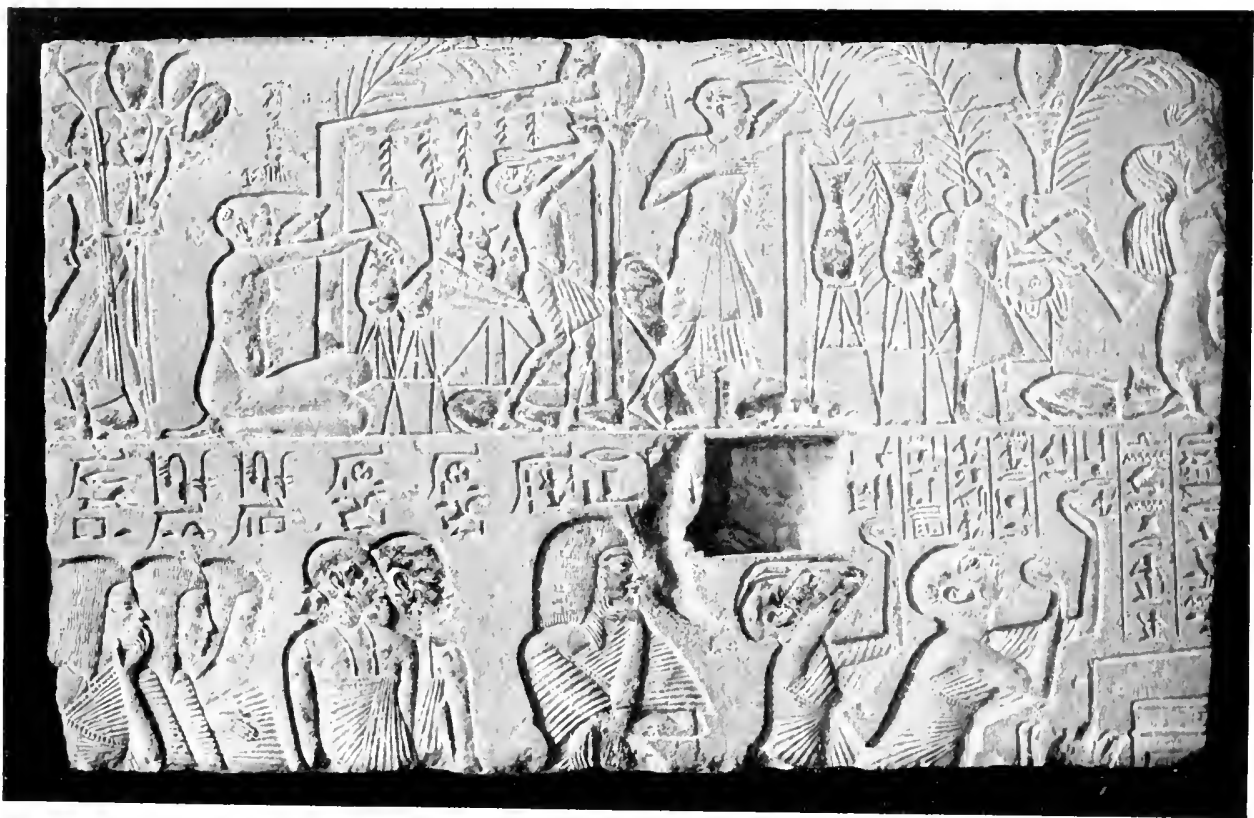

S.IALL IUNERARY TENTS REPRESENTED ON A BAS-RELIEF IN THE IBERLIN MUSEUM 


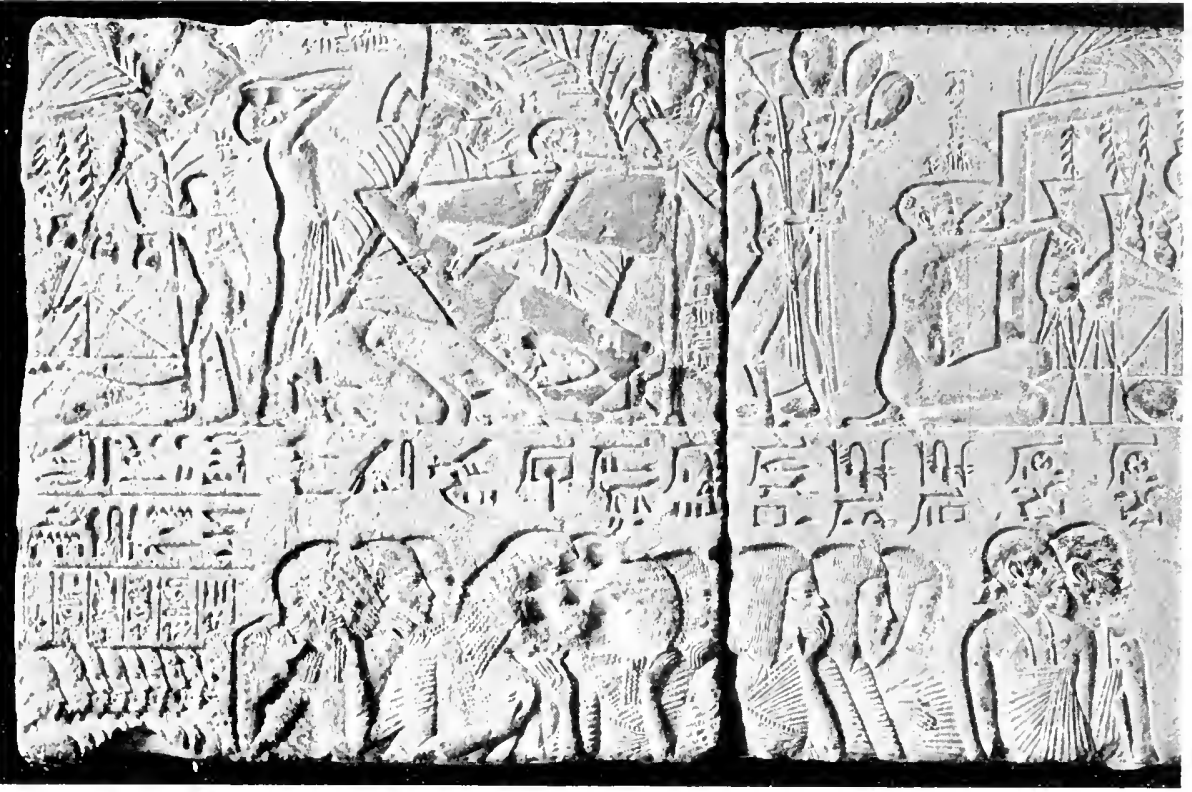


PLATE LII

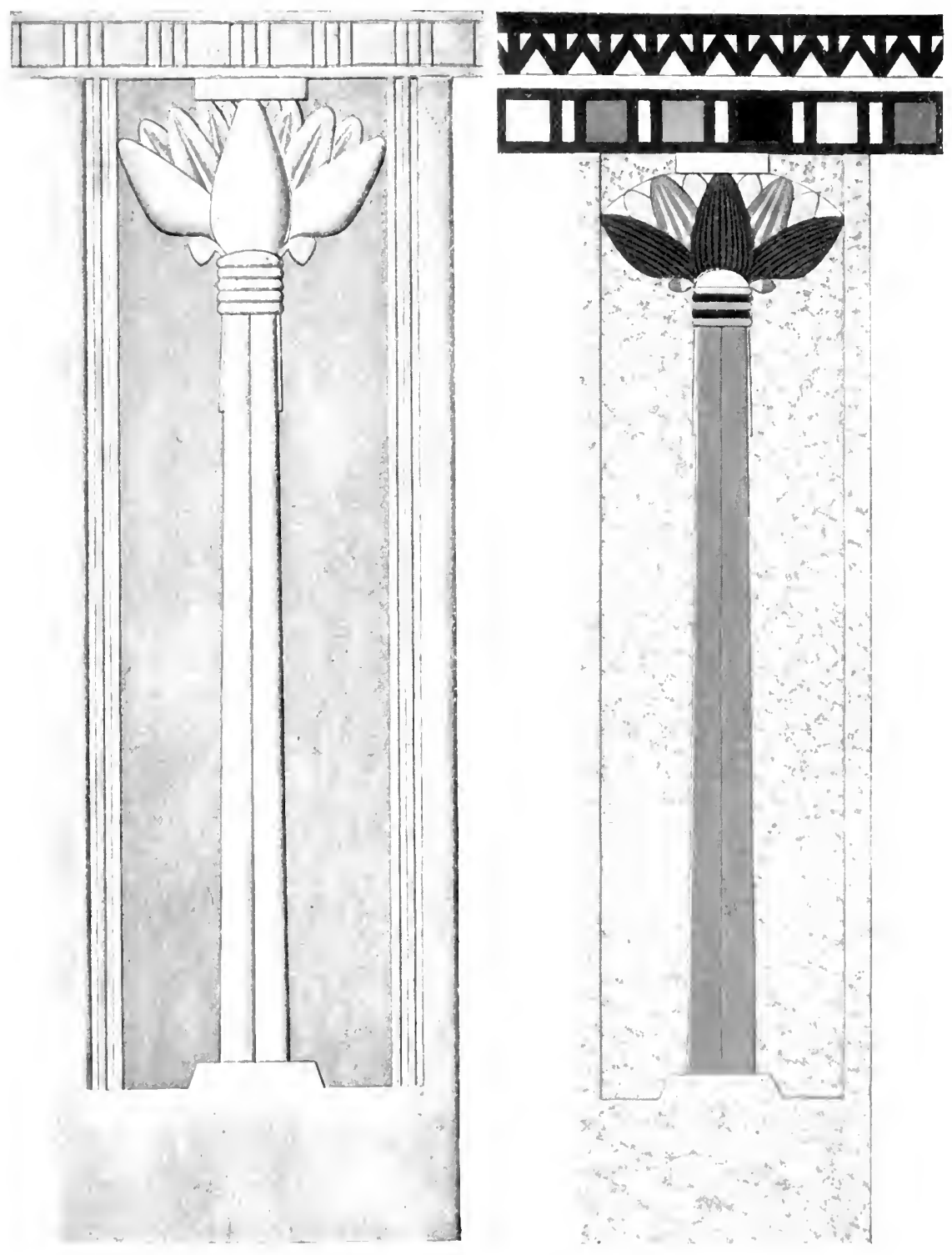


temples they aimed at copying the forms thus obtained, they failed to understand that the stones had to be arranged in a manner corresponding to the arrangement of the bricks. Instead, they superposed a series of blocks on the corbel principle, and then had to trim off the ends of these blocks so as to make a perfect semicircle. This may be seen, for instance, in the Chapel of Offerings at Deir-el-Bahari or in the sanctuaries of the temple of Seti I at Abydos.

Certain types of naos betray at first sight evidences that they are copied from one material into another, and this occurs down to the latest times. The granite naos of Euergetes II and Cleopatra at Debod shows this quite clearly. (27) It copies a shrine which is itself placed under a canopy supported by slender columns, and which recalls a hieroglyph of the Ancient Empire which already expressed the same notion.

These few examples will enable us to understand that there existed in Ancient Egypt an architecture which is not quite the same as the architecture which has come down to us. This architecture, which we perceive throughout the drawings of architectural representations, might be called that of "the living," as opposed to the other, which is rather that of the gods and of the dead. Thus the Egyptians made abundant use of brick, wood and stucco for building their palaces and houses, but these flimsy and ephemeral materials would not meet the needs of almost unlimited durability which the houses of the gods or of the dead manifestly required. Numerous historical texts prove that one of the first cares of the builder kings was to replace by stone buildings the brick or wooden temples which their predecessors had erected and which were falling into ruin.

A Theban painting is very instructive in this respect. (28) We see represented there a house of slender and elegant proportions. It is a domicile which consists of a groundfloor, an upper storey, and a gallery supported on little columns. In the foreground is a broad balcony. A portico with tall slender papyriform columns with open capitals shades the house, the whole of which appears to be underneath a roof supported by columns. Draperies are suspended from 
the cornice. The more one reads the general descriptions of Egyptian architecture in the various handbooks, which are often very summary, the more one realises that they do not fit in with this picture in the least degree. We should be tempted to say, with every appearance of reason, that the vast and majestic monuments which have come down to us through all the ages really give us no more than a faint echo of the real creations of the architecture of ancient Egypt. Desiring, for practical reasons, to build for all eternity, without at the same time renewing all the traditional themes, the Egyptian architects were obliged to deform their works, and to make them heavier even to the point of modifying their character fundamentally. We might imagine, by way of comparison, the absurdity of a modern architect who persisted, in the stone buildings, upon copying the forms which would be combined in the architecture of a building of steel construction. We have, then, to rid ourselves as far as possible of a veritable optical illusion when we examine the greater number of the architectural productions of Egypt, at least in their first development.

The same question is equally in evidence when we begin to study sculpture. Here, with a stone original before us, we have to ask ourselves whether the forms were combined in this material or if they owe their origin to wood, to ivory, or even to metal. The conditions under which these materials are preserved differ so much that they must be taken into account in any attempt to reconstruct what may have taken place in ancient times. The causes of destruction of statues are numerous. Egypt, possessing no metalliferous strata, had always to import the raw material from abroad, and consequently all objects of metal were liable to be melted down and recast. If a bronze statuette of late period could tell us its history, it might perhaps tell us that it had come down from age to age through many different forms. It is not at all surprising that metal statues are so rare. Wood, on the other hand, is liable to every possible cause of destruction : dampness, fire, and even the voracity of white ants. The very nature of the statues, moreover, which made them idols in the eyes of Christians and of 
Arabs, exposed them to complete destruction unless the material of which they were made was of extreme hardness. (29) It would be rash to attempt any kind of statistics in this place, but to gain some idea, it may be supposed that for every thousand metal statues scarcely one has been preserved, whilst in the case of stone statues it is quite possible that only Io per cent. have withstood all the causes of destruction. Thus the ancient numerical proportion would be completely reversed. Can anything analogous be quoted in the case of Greek art? How much actually remains of the masterpieces of the Ionian bronze-workers-of the works of Myron for instance-other than copies in stone made in Roman times?

Bearing these facts in mind, let us now examine a few Egyptian statues of different periods, beginning with the large metal statue of the Ancient Empire found at Hierakonpolis and representing the King Pepi and his son. (30) The bronze-worker could without any risk detach the arms from the body and separate the legs. In this statue there is no support calculated to impart solidity to it except the very nature of the metal itself, which suffices to attain this end. The same freedom of action could be obtained in wooden statues. But how is the same pose rendered in stone? The two statues of Sepa in the Louvre are manifest attempts to represent in model in the selfsame attitude. (3 I) In point of fact the left leg is advanced, but it is only advanced timidly, and thus gives the legs, which touch, absolutely monstrous proportions. The left arm, which grasps the staff and which ought to stand out freely in front, is placed in contact with the chest, so that the staff itself passes down the body and between the legs. The right arm is attached to the body throughout its length, the palm of the hand resting upon the thigh : between the thumb and the forefinger is inserted the sceptre or mace, which is sculptured in relief along the arm. Is it possible to doubt for a moment that we have here a clumsy example of transposition into stone of forms which had long been executed in wood, or perhaps even in metal?

The Egyptians, it is true, rapidly succeeded in perfecting 
the process and of ridding it of most of its clumsiness, but only by recourse to supports, such as dorsal pillars and tenons of stone fixing the members to one another or to the body. In one of the statues of Ra-nefer (32) the action is free and firm, and one might easily forget the high backplate which rises as far as the neck as well as the stone tenons inserted between the arms and the body. Now if we look at the statue in profile-a point of view which the Egyptians probably never contemplated, since the statue was destined to be stood in a niche-the artificiality is at once apparent. The Greeks solved the problem in the same way, but more elegantly, by means of certain accessories, such as drapery or the trunk of a tree. With regard to the arms, the Egyptians dropped the traditional position, and made them hang at full length on either side of the body. The hands, however, are not open, but are grasped about a sort of little baton as a substitute for the customary staff. (33) In this connection we may note that it is typical that the statues of women never hold the baton, but are always represented with open hands.

We may now conveniently cite some other examples. Amongst the statuettes representing servants, one of the most frequent is the miller grinding corn. It is known in wood (34), where naturally the arms are skilfully detached from the trunk. There is, it is true, a specimen at Cairo (35) which shows the same action in stone, but generally working in stone the sculptor has been less daring. (36) Fearing lest the arms should be broken in process of separating them, he has left between the grinding-stone, the arms and the body of the woman, a mass of unworked stone. This is even more noticeable in the figure of a woman standing upright, who is in the midst of the process of brewing beer. (37)

The same thing often occurs in later periods: the tenons are sometimes so well adjusted that they are scarcely perceptible to the eye, as in the beautiful statue of Ramesses II presenting a table of offerings, (38) while in another statue of the same king the whole effect is spoilt by the sculptor's lack of courage in cutting away the stone. (39) 
PLATE I,III

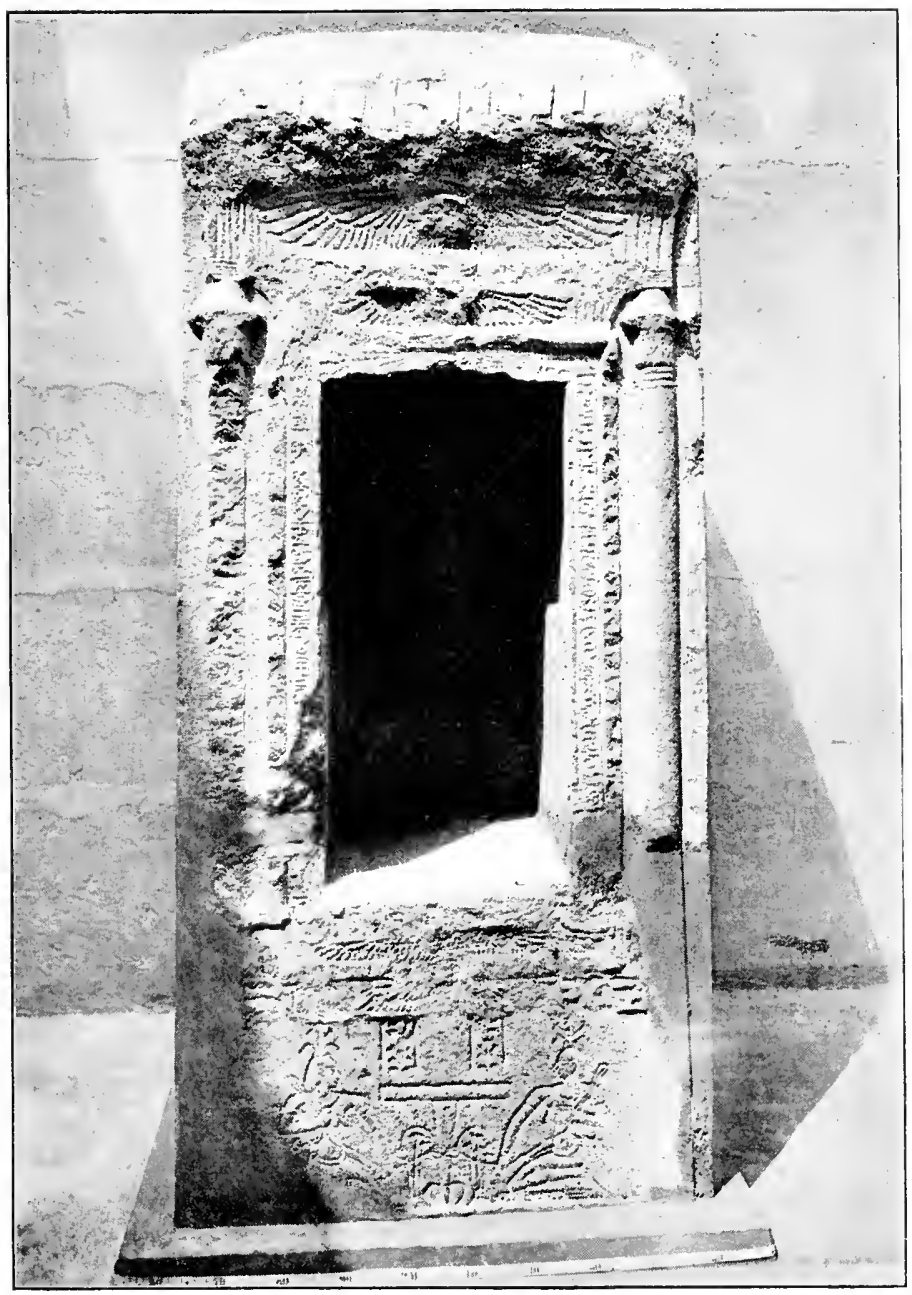




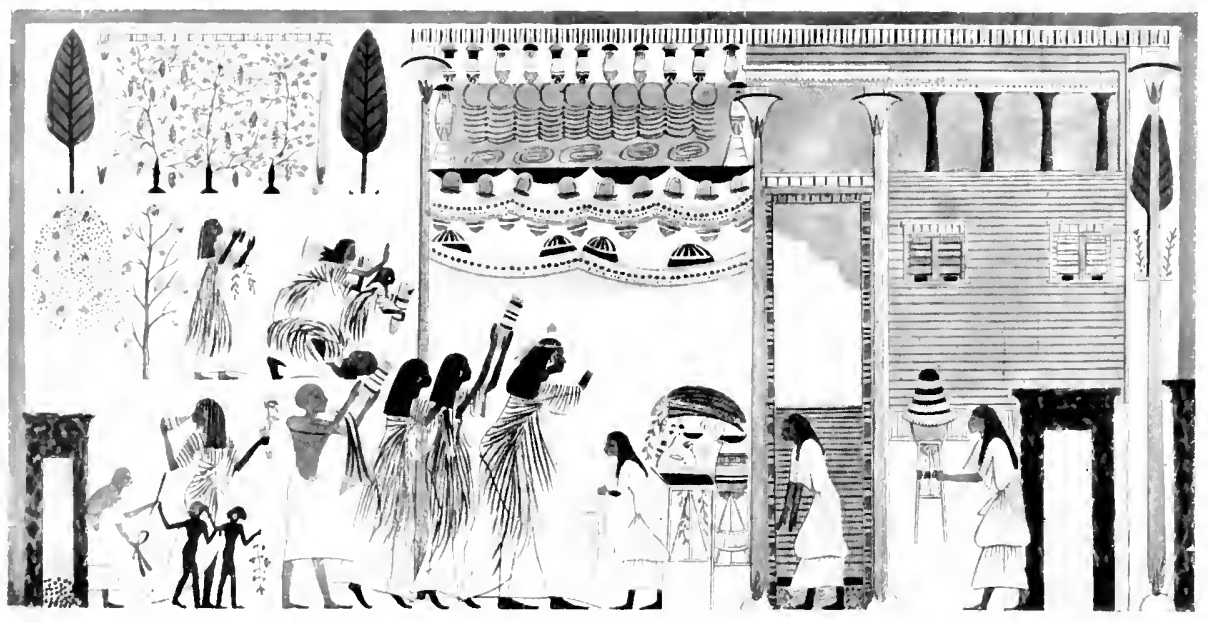


PLATE LV

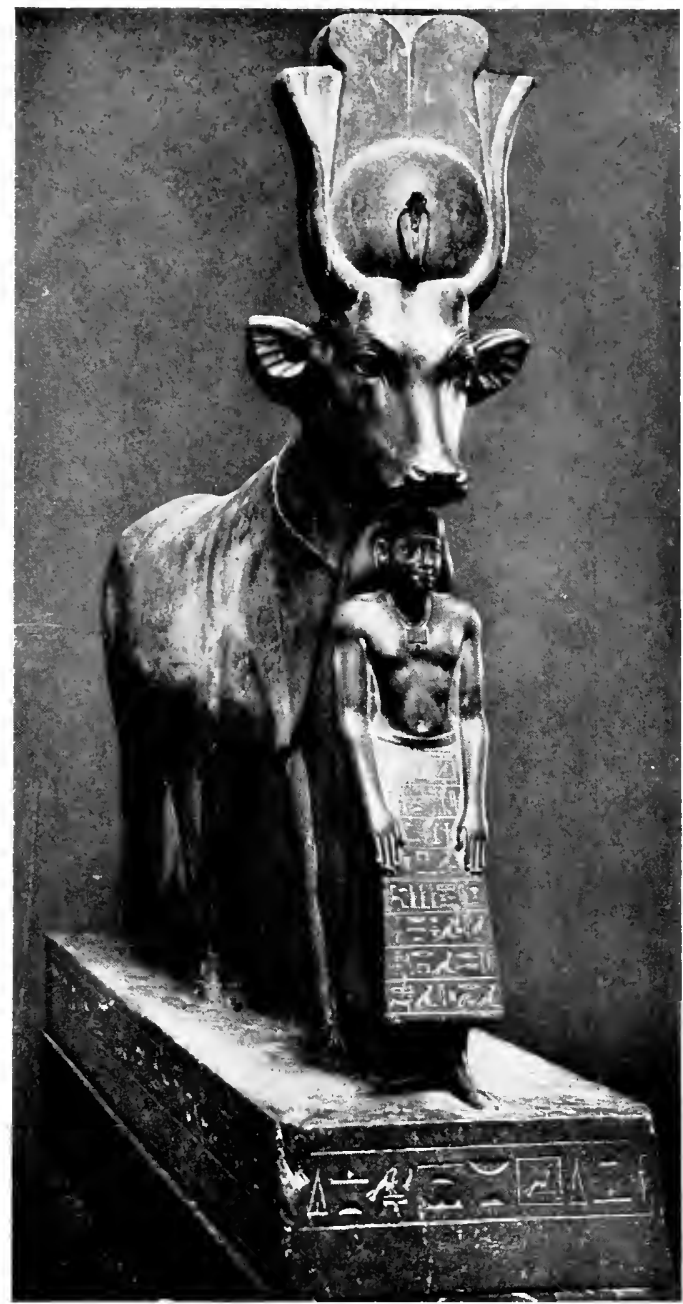

HATHOR-COIV OF THE SAITE PEIRIOD

FROM BISSING, DENKMÄLER ÄGYPTISCHER SCULPTIR 
PLATF LII

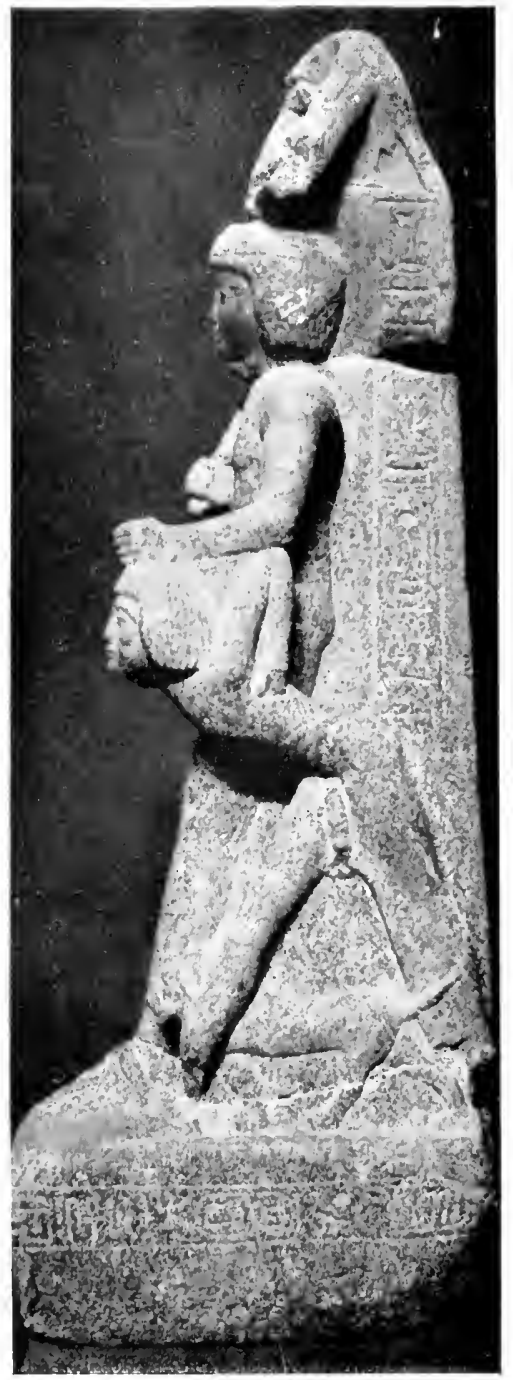


In figures of animals, when worked in stone, it is impossible to detach the legs, and a thick mass of stone is left between them, with the logical consequence of the representation of two legs on either side, which does not produce a happy effect. The fine sculpture of the cow of Amenophis II from Deir-el-Bahari (40) is to some extent spoilt by this feature if seen in side view. A sculptor of the Saite period has overcome the difficulty by carving on each side of the central mass all four legs of the cow, but this is rather a process in bas-relief than in the round. (4I)

If the rendering of isolated figures presented such difficulties, one will understand the position when groups in stone were concerned. These, moreover, are very rare. The figures, as we shall see, are juxtaposed rather than grouped; but a remarkable exception is furnished by a monument of Ramesses VI (42), in which an attempt is made to render a scene already known to us by the bas-reliefs : the king immolating a vanquished enemy with his club. The arm which should be raised above the head, brandishing the weapon, is carefully placed against the chest, as we have just seen in the case of the left arm of Sepa.

It is possible that difficulties of execution may explain in a similar way a process which we notice frequently in family groups, particularly in the Ancient Empire. The principal personage is represented in large dimensions, whilst on the lower part of the group are sculptured representations of the wife and children. (43)

We may instance a few examples of supports whereby it is possible to render elements which stand out from the principal mass of the statue, as, for example, the religious emblems held in the hands of kings or of priests. It will be remembered that on a pillar at Florence, to which reference was made earlier in this chapter, a high-priest of Ptah is seen holding a tall staff surmounted by the head of a lioness. Numerous statues of the New Empire show us persons holding staves surmounted by heads of various kinds. The staff itself is joined on to the body, which presents no difficulty; the sacred emblem is brought to the same level as the shoulder, in such a way that it is 
attached to the head of the figure. We may cite as an example a statue of Ramesses III holding a wand surmounted by a ram's head, (44) or a statue usurped by the first prophet of Amon, Seshonk, where the wand bears a head of the goddess Hathor. (45) The religious ensigns were often supported, as we have seen, by a kneeling figure. This type is likewise transposed into stone with even greater modifications. Senmut, the famous architect of the XVIIIth dynasty, is represented, in a statue found in the temple of Mut at Karnak, (46) in a kneeling posture, holding before him the upper part of a Hathor emblem. A thick block of stone, which makes the whole production heavy, is left between the emblem and the body of the man who holds it. Another example combines two different emblems : this is the statue of Horkheb, of the XXIInd dynasty, where the kneeling figure holds before it a kind of pedestal, bearing on its anterior face the upper part of the Hathor emblem and on the top a ram's head. (47)

\section{BIBLIOGRAPHY.}

I. Borchardt, L., Die ägyptische Pfanzensäule, Berlin, r 897, pp. 53 sqq.

2. Wilcken, U., Die Bedentung der ägyptischen Pfanzensäulen, in the Zeitschrift für ägyptische Sprache, t. 39, 1901, pp. 66-70.

3. Borchardt, L., Die Cyperussäule, in the Zeitschrift für ägyptische Sprache, t. 4 , $1902-3$, p. 49.

4. Spiegelberg, W., Der Stabkultus bei den Agyptern, in the Recueil de traraux, t. 25, 1903, pp. 184-90; Varia, \$LXXXII, zur ägyptischen Stabkultus, ibid., t. 28, 1906, pp. 163-5.

5. Gorringe, H. H., Egyptian Obelisks, London, 1885.

6. Bissing, F. W., Lesefrüchte, $\$ 38$. Obeliskenpaare vor Gräbern, in the Recueil de travaux, t. 34, 1912, pp. $2 \mathrm{I}-2$.

7. Capart, J., Le Temple de Séti Ier, Brussels, I9I2, pls. XXVIII-XXIX,

8. Milani, L. A., Il R. Museo Archeologica di Firenze, Florence, I9r2. t. ii., pl. I.

9. Boeser, P. A. A., Die Monumenten von het nieuwe Ryk. Part I, Graven, La Haye, I9I r, pl. XXVIII.

Io. Mariette, A., Abydos, t. ii., Paris, 1880, pl. 33; Steindorff, G., Die Blütezeit des Pharaonenreichs, Bielefeld, 1900, fig. 66, p. 77.

i I. Capart, J., Le Temple de Séti Ier, Brussels, i 9i 2, pl. XLVI.

12. Lepsius, R., Denkmäler, Part I, pls. I14-I5.

13. Prisse d'Avennes, Histoire de l'Art égyptien, Paris, 1878, t. i., pl. 36, 
14. Wilkinson, G., The Architecture of Ancient Egypt, London, I850, pl. XI, fig. 4 .

I 5. Chapter V, p. 77.

16. Mariette, A., Abydos, t. ii., Paris, r880, pl. 10.

17. Blackman, A. M., The Temple of Derr, Cairo, I913, pl. LXII.

I 8. Gauthier, H., Le Temple de Kalabchah, Cairo, I9I I, pl. III sqq. See Röder, G., Die Blumen der Isis von Phile, in the Zeitschrift für ägyptische Sprache, t. 48, I910, pp. I I 5-I 23.

19. Prisse d'Avennes, Histoire de 'Art égyptien, Paris, 1878, t. ii., pl. 68.

20. Bouriant, U., G. Legrain and G. Jéquier, Monuments pour servir à l'étude du culte d'Atonou en Egypte, t. i., Cairo, 1903, pl. I.

21. Mariette, A., Voyage dans la Haute Egypte, Cairo, 1878, t. ii., pl. 49 ,

22. Maspero, G., Egypi (Ars Una), London, r 92 I, fig. 435, p. 227.

23. Erman, A., Aus dem Grabe eines Hohenpriesters won Memphis, in the Zeitschrift für ägyptische Sprache, t. xxxiii., I 895, pls. I-II ; Puchstein, O., Die Ionische Säule, Leipzig, 1907, figs. 22-4, Pp. 20-r.

24. Lepsius, R., Denkmäler, Part I, pl. 57 ; Prisse d'Avennes, Histoire de ''Art égyptien, Paris, I878, t. i., pl. I 5 .

25. Borchardt, L., Das Grabdenkmal des Königs Nefer-ir-ke-re, Leipzig, 1909, fig. 20, p. 22.

26. See Chapter VI, pp. $9^{\mathrm{I}-2 .}$

27. Röder, G., Debod bis Bab Kalabache, Cairo, I9 I I, t. ii., pl. 36.

28. Rosellini, Monumenti cioili, pl. 68 ; Erman, A., Life in Ancient Egypt, London, I 894 , p. 176.

29. See Kugener, A., Vie de Sévere par Zacharie le Scholastique, in the Patrologia orientalis, by Graffin and Nan, t. ii., I, pp. I6 sqq.

30. Quibell, J. E., and F. W. Green, Hiérakonpolis, Part II, London, I902, pls. L-LII.

31. Bissing, F. W., Denkmäler ägyptischer Sculptur, Munich, 1914, pl. 5 .

32. Capart, Jean, Some Remarks on the Sheikh el-Beled, in the Journal of Egyptian Archa'ology, t. vi., I 920, pl. XXVI.

33. Spiegelberg, W., Varia, \$LXXXVIII. Der "Steinkern" in der Hand von Statuen, in the Recueil de travaux relatifs à la philologie et à l'archéologie égyptiennes, t. 28, r906, pp. 174-6.

34. Capart, Jean, Recueil de Monuments egyptiens, t. ii., Brussels, I905, pl. LIII.

35. Borchardt, L., Statuen und Statuetten von Königen und Privatleuten (Catalogue général), t. i., Cairo, IgI I, pl. 25, n. I I4.

36. Ibid., pl. 24, n. I Io.

37. Ibid., pl. 26, n. I 18.

38. Legrain, G., Statues et Statuettes de rois et de particuliers, t. ii., Cairo I 909, pl. IV.

39. Ibid., pl. VI.

40. Naville, E., The XIth Dynasty Temple at Deir-el-Bahari, Part I, London, I907, pls. XXIX-XXX.

4I. Bissing, F. W., Denkmäler ägyptischer Sculptur, Munich, I9 I4, pl. 73.

42. Legrain, G., Statues et Statuettes de rois et de particuliers, t. ii., Cairo, 
1909, pl. XV ; Bissing, F. W., Denkmäler ägyptischer Sculptur, Munich, I 914 pl. 55 b.

43. Borchardt, L., Statuen und Statuetten von Königen und Privatleuten, t. i., Cairo, I9Ir, pl. Ir, n. 44 ; pl. 16, n. 62, etc.

44. Legrain, G., Statues et Statuettes de rois et de particuliers, t. ii., Cairo, 1909, pl. XIII.

45. Ibid., t. iii., Cairo, 19I4, pl. III.

46. Benson, M., and J. Gourlay, The Temple of Mut in Asher, London, I 899, pl. XII, p. I 64.

47. Legrain, G., Statues et Statuettes de rois et de particuliers, t. iii., Cairo, I9I4, pl. XXIII. 


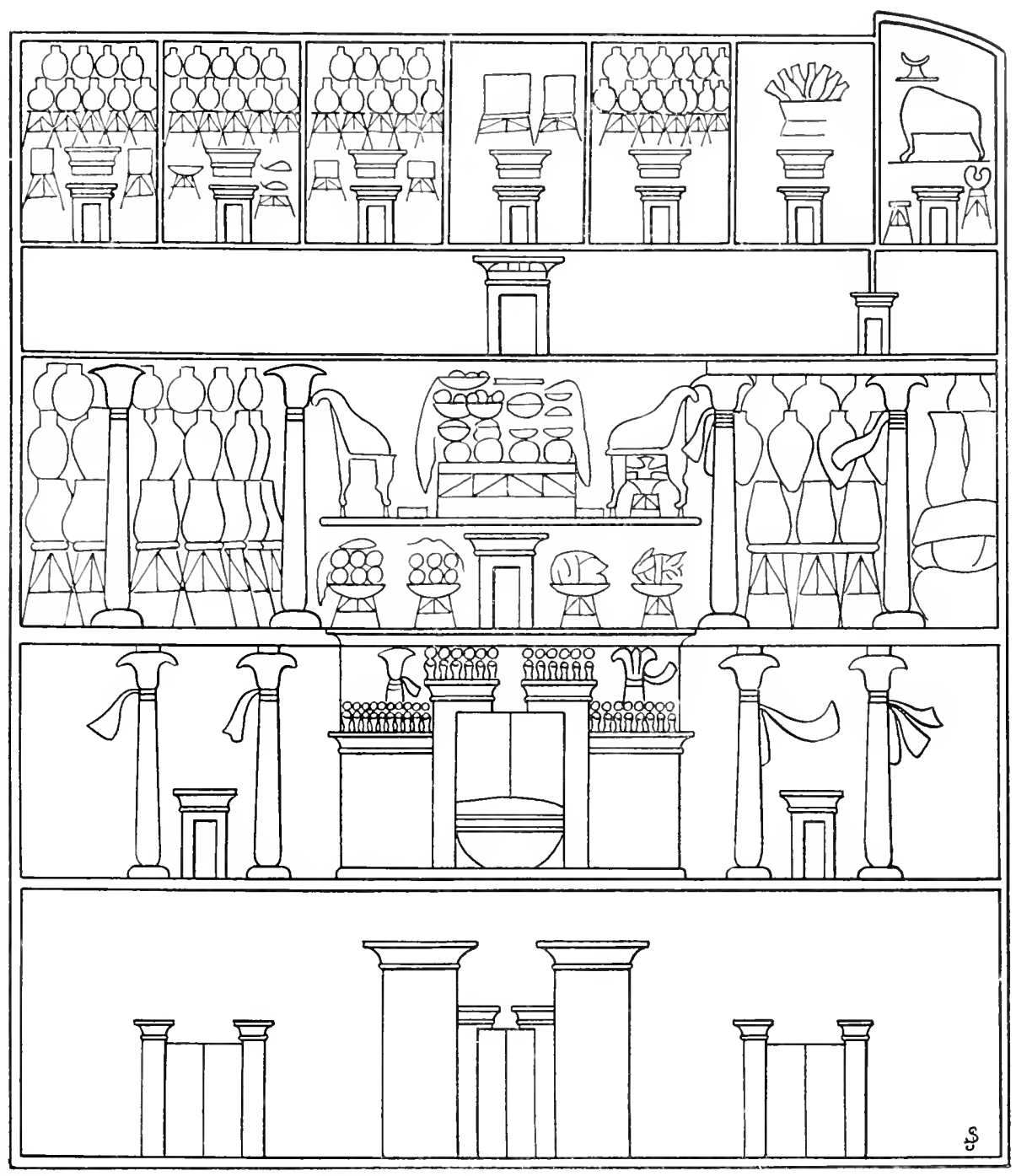

THE PALACE OF AMENOPHIS IV REPRESENTED FULL-FACE 


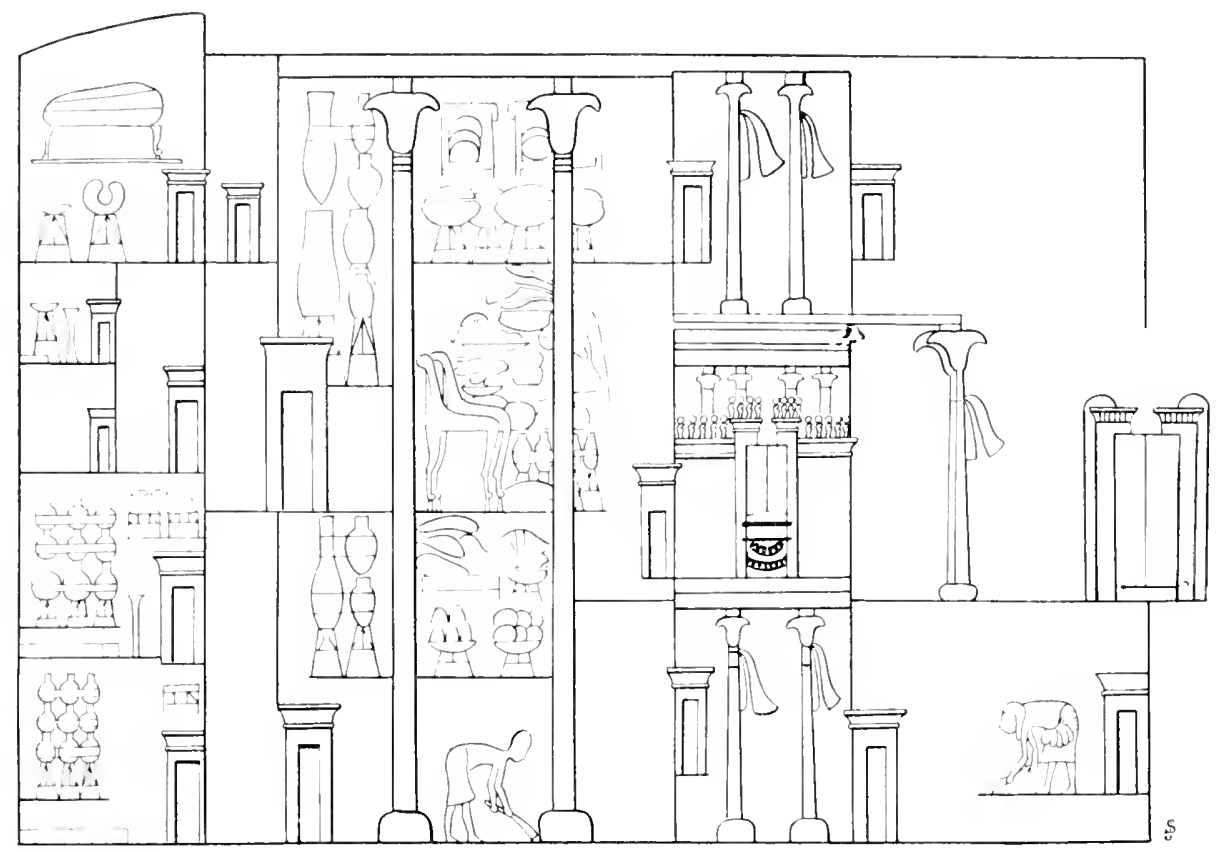




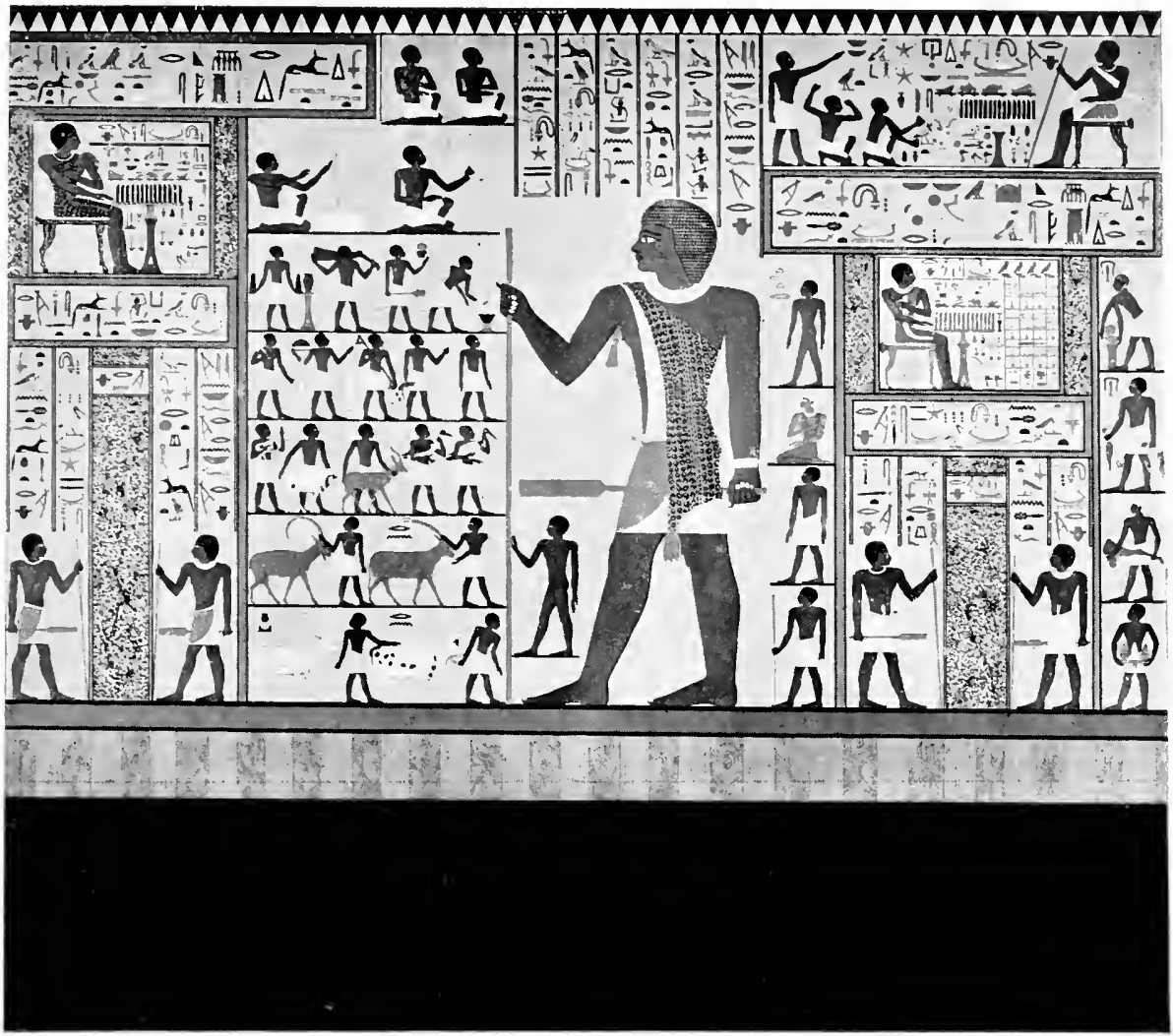




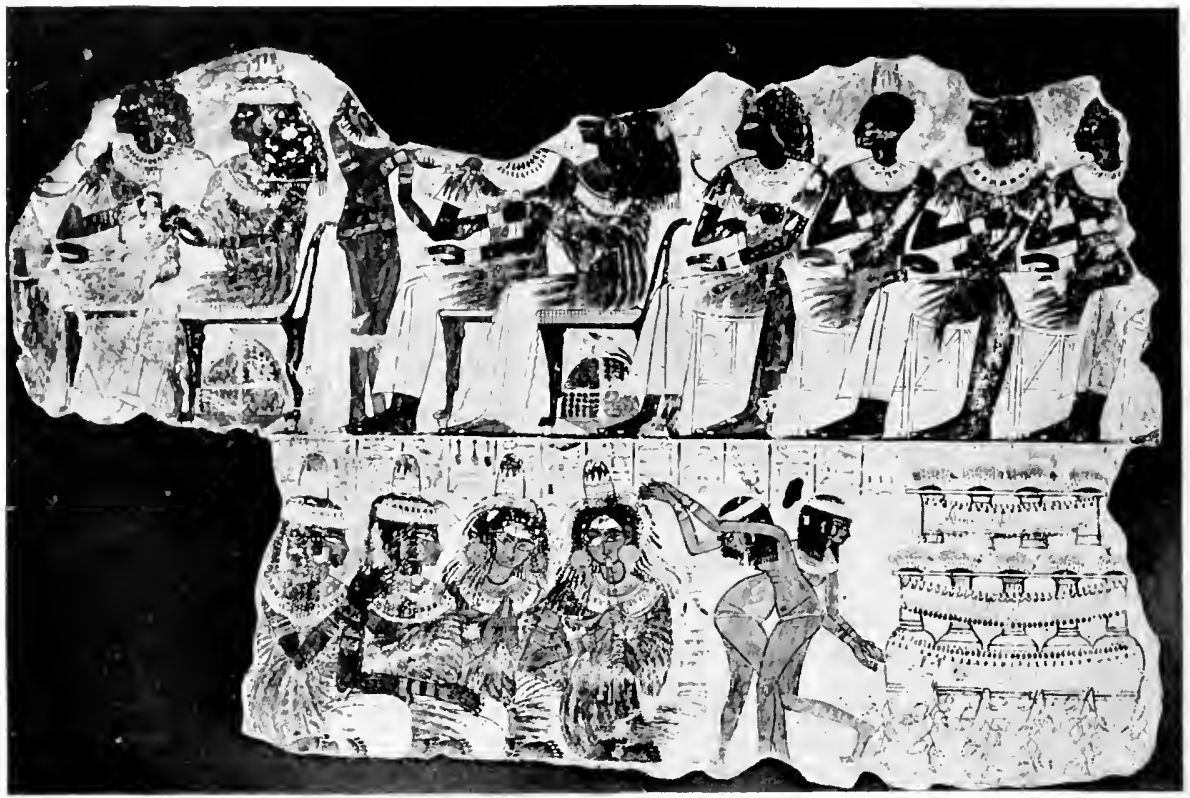


CHAPTER $\mathrm{X}$

\section{THE CONVENTIONS OF EGYPTIAN DRAWING}

\section{Plans.}

$\mathbf{W}$ HEN the Egyptians drew plans they combined various modern principles-plan, elevation and section. We will first of all take a purely theoretical case. If the Egyptians wished to draw a storechamber full of jars, they traced the plan just as we should ; then at the doorway they drew the outline of the door in elevation; finally they carefully filled all the free space with jars ranged one above the other. We will suppose that the door faces us as we look upon the plan, but if the door is in one of the lateral walls, instead of drawing it flat, the Egyptian preferred to stand it up, describing a quarter of a circle from the base, so that it stands upon the base-line facing the spectator, the details of the outline of its frame being carefully indicated. The examination of several examples will enable us to follow more accurately what has just been stated in general terms.

Egyptian plans have been discovered upon papyrus, upon limestone flakes, or upon potsherds (ostraka), and again-and these are important-upon the walls of tombs at Thebes and at Tell-el-Amarna. As specimens of simple plans we may cite the plan of a royal tomb, preserved in a papyrus in the Turin Museum, (I) and another on a slice of limestone in the Cairo Museum. (2) In the tomb of Nefer-renpet (a contemporary of Ramesses II) at Thebes, who was in charge of the treasury of Amon, the administration of the temple of the great Theban god is represented. (3) A great gateway, which is laid horizontally, opens out of an 
alley planted with trees. Within a large court may be seen different chambers, the doors of which are planned in three different directions: upwards, downwards and laterally. In the storehouses of the temple of Tell-el-Amarna, depicted in the tomb of Meryra, the buildings are arranged in four groups of rooms, separated by a cross-shaped courtyard planted with trees. (4) Here all the doors which would face the spectator in a picture of the site are traced standing upright; all the lateral doors, on the contrary, are turned as a pivot for a quarter of a turn before being drawn in the plan. It must also be observed how the porticoes which run along each range of storehouses are treated. The columns are placed on end one above the other, but separated by the architraves, which join them to the lintels of the doorways giving access to each of the rooms. (5)

Certain monuments at Tell-el-Amarna are represented several times-now seen in profile, now full-face, which enable us to make some interesting comparisons. It will be better for the moment to leave aside the extraordinarily complex representations of temples, in which many of the elements are extremely difficult to interpret by our modern conceptions, so we will confine ourselves to a description of the more simple representation of the palace of Amenophis IV depicted in the tomb of Meryra.

The first picture shows us the building full-face. (6) We will begin by studying its plan. The thing that meets the eye is a large court, then three rooms of almost equal size which fill the whole width of the building, after which is a large hall occupying the whole width; behind this is a corridor from which a series of chambers opens; at the end of the corridor a little antechamber gives access to the furthermost room. We must now examine the architectural details drawn upon the plan. Access to the building from the court is gained by a great porch in the centre, and on each side of it by a door of smaller proportions. At the end of the court is a large room of which the roof is supported by columns, and its anterior part, which is not completely walled up, is occupied by a balcony wherein the king sits on the occasion of festivals and receptions. 
The balcony-hall is flanked by two other chambers, the ceilings of which are upheld by open-capitaled papyriform columns. The great broad hall, with four columns in its width, is evidently the dining-room ; in the centre may be seen the table loaded with provisions, on either side of which are chairs. On stands and racks are arranged provisions and large jars. A single door leads from the diningroom to the corridor beyond. All the chambers which open directly upon the corridor seem to contain stores of various kinds, whilst the last, which is reached by a little vestibule at the end of the passage, is none other than the king's bedroom. Here the bed may be seen with its mattress and pillow.

Another picture shows the palace in profile. (7) Here again we see first the court, the plan of which is necessarily drawn this time lengthwise instead of broadwise. The great porch is turned round to face the spectator before being drawn in the plan. Below is a smaller door : the upper door, for some reason, has disappeared. In the axis of the great doorway we can recognise the balcony-hall, which is planned so as to present it full-face, but it has undergone considerable contraction in order to fit it into the available space. Here too an additional detail may be discerned, for the balcony is preceded by a portico, supported on two columns, which is omitted from the full-face picture. Above and below the balcony are the lateral chambers, with the doors leading to the court and to the dining-room, which are omitted in the first picture. We now come to the dining-room, the ceiling of which is supported by two rows of columns arranged lengthwise, which seems to imply that there were two rows of four columns each. It is noticeable the drawing indicates rather the type of the columns than their proportions. Their size in the picture is governed purely by the space available for them; accordingly they are foreshortened in the front-view picture and elongated in the profile view. In the centre we see the table and the two royal chairs, and as in the first picture they were placed symmetrically on either side, in this one they are evidently placed side by side. At the end of the corridor which 
leads to the farther rooms we find the little vestibule which gives access to the king's bedroom. There can be no doubt whatever but that both pictures represent one and the same domicile, and the arrangement of the various elements reveals in a particularly clear manner the conventional processes employed in Egyptian plan-drawing.

We have just seen one architectural part, the balconyhall, traced on the plan as having been partly turned round -a device which is often resorted to in depicting certain details. Thus, in a bas-relief of the temple of Luxor in which the façade of the temple is depicted, the royal colossi which adorn it are drawn in profile as though they were turned round in such a way as to look upon persons entering the building, although in reality these colossi, which have survived to this day, are seated with their backs to the structure of the pylon. Here the figures are turned symmetrically towards the interior; in the tomb of Amenhotep-si-se, on the face of a pylon the colossi are turned round so as to look outwards. (8)

Composition of the Human Form.-In drawing the human figure similar artifices were employed to those we have just dealt with in the case of architectural drawings : the Egyptian, in drawing a man in profile, nevertheless lays down in plan all such parts as do not appear to him to be sufficiently characteristic in silhouette; that is to say, the shoulder-line and part of the kilt. Moreover, he never omitted to draw the eye full-face on a head seen in profile. We will take as an example one of the panels of Hesi which dates from the end of the IIIrd dynasty, one of the earliest examples we have of large upright figures drawn with full detail. (9) The face is in profile, the chest also; the line of the back, too, is seen from the side, and the sculptor has been careful to indicate on the other side the nipple of the breast. The position of the navel shows that the belly is likewise in profile, whilst the shoulder-line, on which the collar-bones are carefully and symmetrically indicated, is absolutely full-face. Here we have a formally conceived process without any attempt to work in some transition between the different points of view. It is not a case of inexperience, as is often 
alleged; it is a habit learned by the draughtsmen in making architectural plans. The pose which we always find in statues in the round shows the subject in the attitude of walking, the left leg advanced, holding a staff in the right hand and a kind of sceptre or mace in the left. The walking figure looking towards the right is the normal and fundamental type. Any example, chosen haphazard from hundreds, would show the subject exactly in this position, but sometimes the clothing displays some variation. Instead of a tightly fitting kilt without folds, we may see a fuller kilt ending in a stiff boardlike piece projecting in front. This kind of projection, which is represented as triangular, is drawn in plan as facing the spectator, instead of being seen in profile. (IO)

It is interesting to compare two figures placed on the same wall and facing one another: for example, those in the tomb of Mer-ab in the Berlin Museum. (II) On the left we have the prince in the normal position looking towards the right : the detail of the hands shows with precision that the hand which grasps the long staff is really a left hand, whilst that which holds the sceptre is really a right hand. This conclusion is confirmed by the fact that the sceptre or mace in the right hand passes behind the body instead of in front. But in this case the left hand, that which holds the staff, ought, instead of showing the fingers, to show the back of the hand, and here we meet with one of the strangest faults of Egyptian drawing. The figure has really two right hands, one of which is attached to the left wrist. Now, if we look at the lower part of the figures, we shall see that the feet are treated in exactly the same manner, so that the left-hand picture of Prince Mer-ab has two left feet, and the right-hand picture two right feet. In the same way we see scribes depicted as writing with a left hand put on to a right arm. The cause of these mistakes has been lucidly explained by M. Pottier, who has shown that they are accounted for by drawing originally from a shadow.(12) A silhouette is of itself neither right nor left, and its determination is exclusively derived from the interior details and lines which are afterwards added. If 
the artist works in a mechanical way and without thinking out each figure, he is liable to fall into serious mistakes such as those we have just noticed. M. Pottier has also shown that the Egyptians transmitted their practices of drawing to the Greeks in the seventh century, and that the pupils, despite all their artistic genius, clung for a long time to the faults of their teachers.

It would be a mistake to imagine that the Egyptians invariably held to these figures, in which different parts seen from two different points of view are superposed without any regard to the difference which exists between the image so rendered and the real image produced by the body on the retina. In tombs of all periods there are what might be called attempts at representations which are more in keeping with our methods of drawing objects. Sometimes, as in the tomb of Horankhma at Saqqara, only half the process is abandoned. A stout man with a fat breast displays a right shoulder which is to all intents and purposes correctly articulated. But the left shoulder, which ought to be concealed by the right, has been drawn in by the draughtsman. It must be admitted that, thanks to the gesture of the figure, who is lifting a group of geese, this misplaced shoulder is hidden by wings and feathers. (13) Certain figures of persons turning round have given an excellent pretext for showing the shoulders full-face upon a body in profile. (I4) We can find no fault in the female figure who is turning round in the banqueting scene in the tomb of Nakht at Thebes, (1 5) but what an awkward movement we perceive in her neighbour, who is offering her an aromatic fruit to smell! Probably with the desire to unite this last figure to the group of women which follows, the artist has arranged the woman's arms in an absolutely impossible attitude. On the other hand, we cannot but unreservedly admire the little nude figure of the slave who bends forward to adjust the ear-ring of one of the ladies, and who is drawn in profile in an absolutely charming manner. Again, we may refer to the figures of young girls in the tomb of Menna: one, standing in the stern of a canoe laden with birds and bunches of flowers, turns round very gracefully. (I6) In the middle 
of the canoe a little naked girl stoops forward with a very natural movement to gather lotus flowers from the surface of the water. In the tomb of Rekhmara we witness a series of groups busying themselves with their mistresses' toilet. (I 7) We see the serving-maids hurrying around their mistresses from one side to the other, some of the figures being drawn on the usual conventional lines, whilst others are represented in perfectly accurate profile; once even, a back-view figure is drawn. (I 8)

A fragment of fresco in the British Museum shows two figures full-face, but this is quite exceptional. (19) Can it be maintained, in view of such examples as these, that the representation of full-face shoulders on a profile body is the result of inexperience in art and of feeble groping in the study of rendering the human figure? No, this process is quite conscious, voluntary and methodical.

Grouping of Figures.-Although countless scenes in reliefs of all periods are available for examination, we will confine our attention here to a few general remarks upon the relative proportions of the figures. It is probable that the fundamental principle was not so much the social importance of the subject as the desire to express the principal action in a clear and distinct manner, and to detach it from other details which were considered as accessory. Let us examine, for instance, a historic scene which shows Ramesses II conquering a Syrian town. (20) Our own historical painters never thought of composing their subject as the Egyptian artist did, but they did not succeed so well as the ancients in producing a picture so telling at first glance. The king, occupying the entire height of the panel, has grasped the Canaanean chief by the hair and is about to behead him. The enemy held fast by the king's right hand must be of the same height as his captor; for it would be absurd to represent the royal fist as falling upon a head of pigmy proportions. The vanquished chief brandishing his bow, placed at the upper end of the crenelated walls of the town, will thus be of the same size as the king. A stage lower down are represented characteristic types of the population : a priest burning incense, a woman lamenting, another with 
an infant, a warrior who has finished shooting with his bow makes a gesture of submission, a woman weeps, a dead man falls from the walls. Could one explain more clearly that the town is conquered and that it has surrendered to its captor? Towards the bottom of the scene, in the free space left between the body of the king and the walls of the fortress, one of the princes is represented who accompanied his father in the expedition.

A fine example of the adaptation of figures to the space available for decoration is afforded by the body of the chariot of Tuthmosis IV. (2I) In the centre stands out boldly the figure of the king fighting in his chariot drawn by a pair of galloping horses. The king has seized by the hair two of his foes who are themselves mounted in a chariot, which is partly hidden behind the horses of the royal team. In front and below, in the free space around the principal episode, is represented an indescribable mêlée, where we see a chariot in flight, and others hurled hither and thither in disorder, smashed, and flinging broadcast upon the ground their charioteers and soldiers transfixed by arrows. Certainly confusion reigns supreme, but it would be difficult to imagine a better means of expressing, in a single glance, the disorder wrought in the enemy's ranks by the triumphal advent of the king.

To introduce some semblance of order, the elements which seem so confused when drawn in mass are sometimes arranged in registers. Thus, for example, in a huntingscene in the tomb of Userhèt, (22) the deceased, shooting from his car in full gallop, has drawn his bow upon numerous animals which fly distractedly but which are nevertheless divided into a series of registers one above the other.

Arrangement of Figures in Groups.-A man and woman who are really one beside the other are drawn as though they were one behind the other. In such cases the two outlines are sharply distinguished from one another : sometimes, and more especially when dealing with exactly similar figures, one is placed over the other so that they almost coincide. In this case the contours follow one another closely, and are the only indication that there are several 


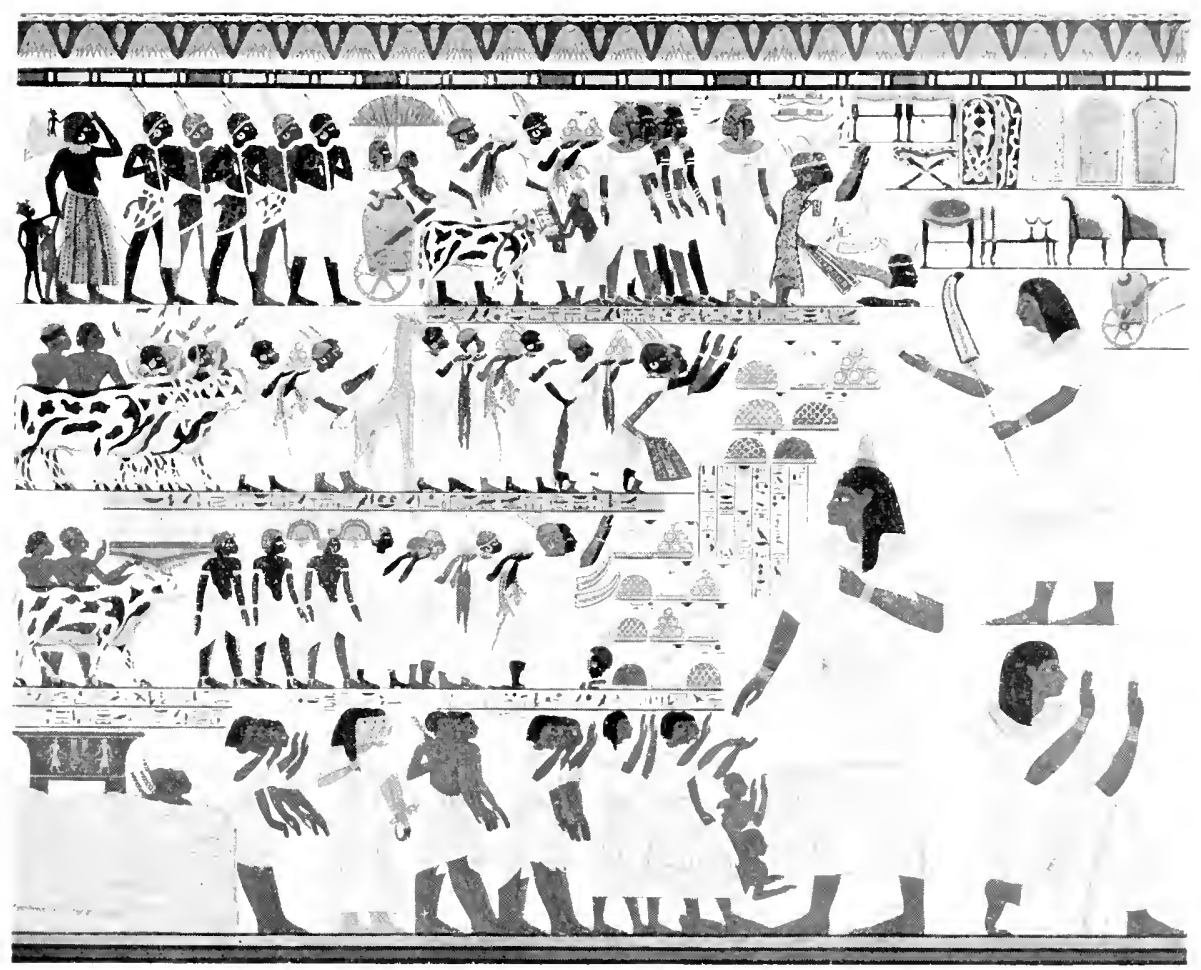




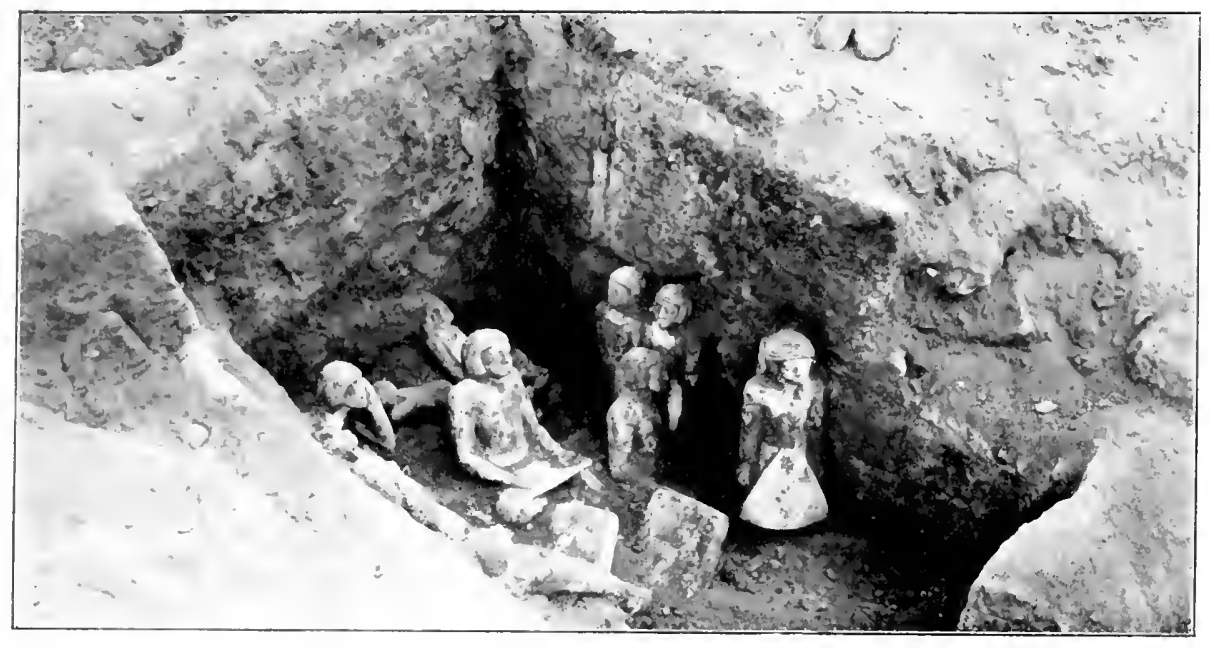

"SERDAB CONTAINING FUNEREAL STATULS EXCAVATIONS OF JUNKER AT GIZEH 


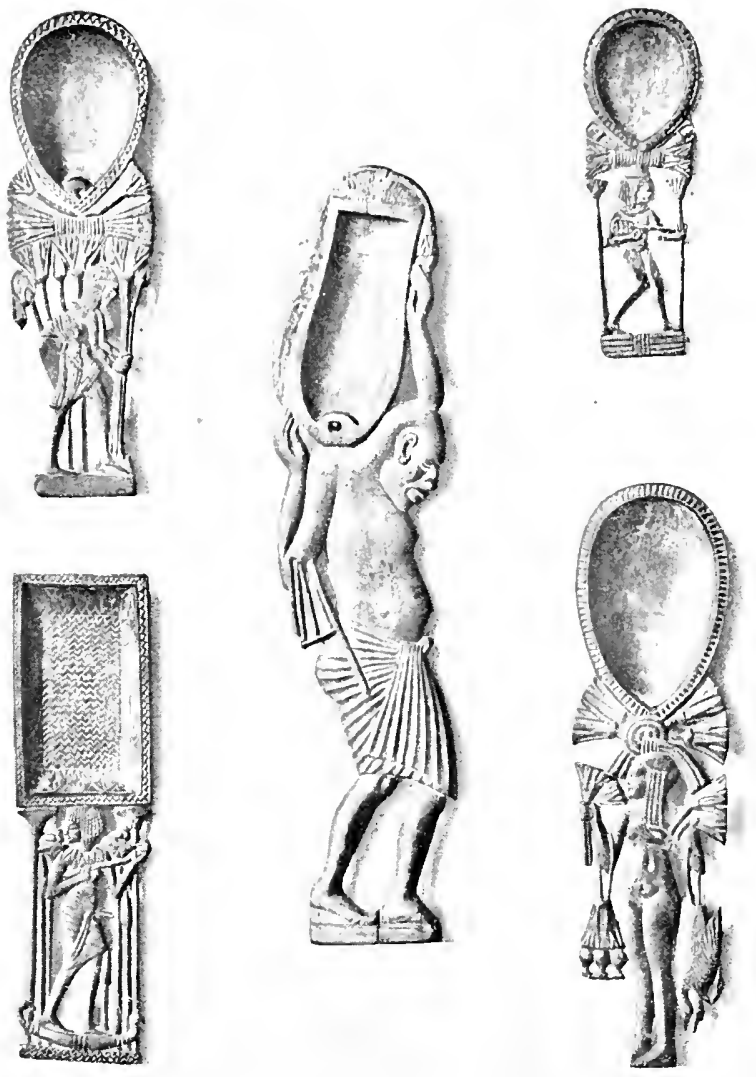


PLATE LXIV

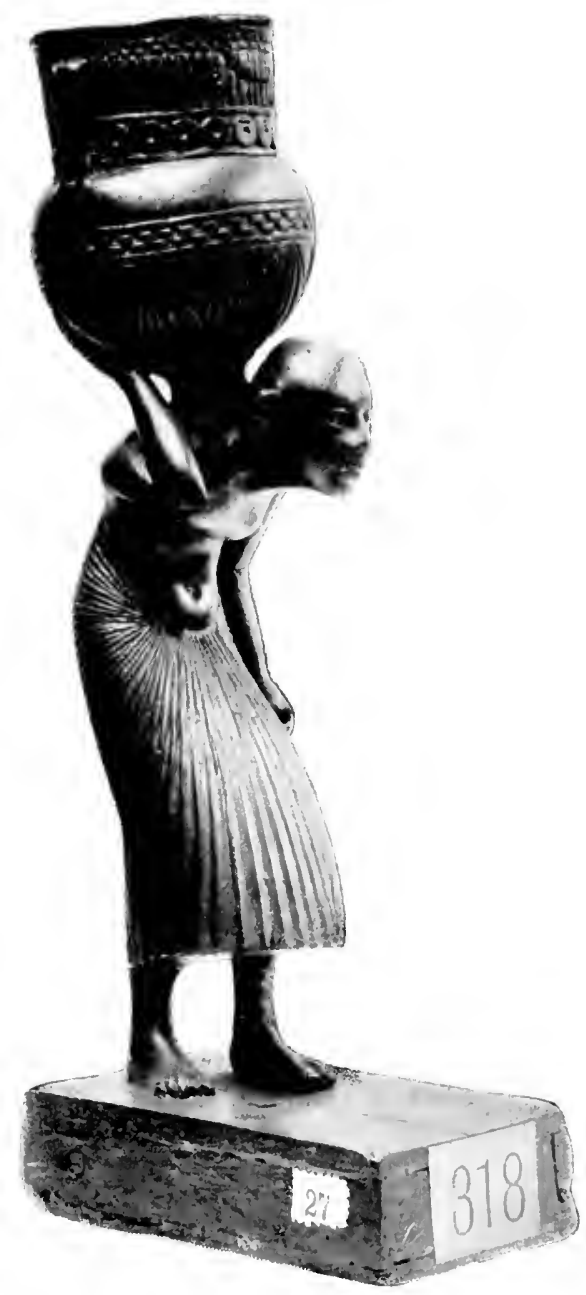


figures side by side. (23) One part of a scene in the tomb of Khaemhet at Thebes is a very instructive study in grouping, both of isolated figures and of groups of two, or even three or four. (24) The silhouettes fall slightly one behind the other, but the draughtsman has considered the figures as really having only two dimensions : otherwise one could not understand the arrangement of the arms of the sitting figures in relation to the bodies of the erect figures which preceded them. As a matter of fact, by this latter means the Egyptians gave effect to true perspective. They failed to understand, however, that the height of the heads must be progressively diminished and at the same time a vanishing line for the feet must be established. In this example (tomb of Khaemhet) the heads are not absolutely all of one height in each group : for some, a slight diminution, but for others, on the contrary, an augmentation in height is introduced-which is absolutely contradictory.

Some weird instances of grouping in outline are furnished by the great temples. The subject is of the king immolating his enemies in the presence of a presiding god. We have seen this theme treated simply in the time of the earliest dynasties, where the king was concerned with a single enemy. But as conquests extended to more and more numerous populations, it was desired to symbolise in a single picture the king's victory over all his foes, and the artifice adopted was to collect a veritable bevy of enemies into the king's grasp. A glance at an example of Tuthmosis III at Karnak (25) will show the whole idea far more clearly than any verbal description. It will be noted that in this group several of the enemies are represented full-face. The execution of some of the faces is such as to lead us to think that the sculptor would not have had much trouble, with a little application, in surmounting the difficulties which this theme presents.

Certain bas-reliefs show attempts to represent deep masses or crowds of people. The arrangement of the different ranks on successive planes is quite regular in the army of Ramesses II on the march, where a bird's-eye perspective is employed. (26) At Beit-el-Walî the tribe of negroes 
vanquished by Ramesses II is put to flight, and is shown dispersed hither and thither on the relief. (27) The group of wailing women in the tomb of Ramose shows an ingenious device to express the crowd of women who make lamentation as the funeral procession draws near. (28)

Complex Scenes.-Representation of different successive "grounds" is obtained by means of breaking up the scene into registers so as to indicate with as much precision and clearness as possible the elements which stretch farther and farther away from the spectator's eye. In the tomb of Ptah-hetep at Saqqara (29) is a scene with a river in the foreground with its plants and fish. On the surface of the stream float papyrus-skiffs the crews of which are fighting with quarter-staves. A little higher, in the marshy thickets of the river, we witness a scene of bird-snaring; farther on again, on dry land, boat-building is proceeding; and finally, in the background, is the desert with its wild animals. In the tomb of $\mathrm{Ti},(3 \circ)$ amongst the agricultural subjects, four successive registers depict the harvest scene in the following order from the top downwards : first, cutting corn ; second, binding sheaves, tying them up, whilst asses, with their drivers, come up in groups to be laden; third, the asses are laden and driven on; fourth, unloading is carried on and stacks built up.

In the tomb of Huy at Thebes, we see Ethiopians bringing tribute to the King of Egypt. The whole procession is broken up into four bands of equal height; at the end of the last band is drawn the doorway through which the whole procession has passed.

Representation of Landscape.-This is always quite summary, the artist being content with mere general and conventional indications. The most frequent subject is the garden, treated in plan with vegetation laid down regularly in four directions as in the tomb of Rekhmara, (31) where the trees, grouped around the pond, are laid down in the four directions (or rather in eight directions, as the trees at the angles lie diagonally). The picture is in a sense radiated in such a way as to suppose that the observer stands in the middle of the scene. Sometimes, however, all the elements 
are laid in one direction only. A comparison should be made between the gardens of Rekhmara and of Amenemheb. (32)

A hunting-ground is often characterised by gentle undulations on which from time to time very modest indications of vegetation occur. An example of this may be found in the temple of Sahure. (33)

In certain agricultural scenes the draughtsmen have attempted to depart from the severe alignment of regular registers, but with not very happy results. Thus, in the tombs of Nakht and of Khaemhèt the labourers are spread along a sinuous stretch of land upon which vegetation and pools of water are indicated. (34)

When the object was to portray historical scenes, as, for instance, the battle of Ramesses II against the Kheta, an attempt is made to recall the characteristics of a particular site, such as the town of Kadesh on the Orontes. (35) A bas-relief at Luxor belonging to a series of this kind gives us the only known example of a really complex landscape, where plants and trees of various species are scattered pellmell. (36) Finally, in the tomb of Amenemheb, the artist has made a daring attempt in the episode of the encounter with a big hyæna. All over the "ground" of the picture plants are scattered at different levels. (37)

We may say, briefly, that the Egyptians never drew according to our laws of perspective, but once their rules are unravelled and understood, their representations are as clear as our own, if indeed they do not permit of even greater precision in that they drew the aspects farthest from the eye with as much detail as those nearest. Nor must we forget that the object of their drawings was quite different from ours. The Egyptian's desire was not to show nature as it appears to our eyes under most different aspects; he sought above all things to depict nature in all its complexity, with such details as he deemed needful, by breaking it up into its component elements. $\mathrm{He}$ accomplished, in fact, more in the way of pictography than of art in its true sense.

Proportions of the Human Body.-It now remains to inquire whether the Egyptians observed the regular pro- 
portions of the human figure, having regard to the limits imposed by the conventions dealt with above. In several tombs, from the time of the Ancient Empire, some unfinished figures may be observed, drawn upon a background ruled in squares; sometimes instead of this network we find merely a few guiding lines, or merely a few points marked off. (38) Ought we to account for these lines and squares simply as a mechanical process of enlarging a drawing, or are they really for determining a canon of proportion? Various authors have successively affirmed and denied the existence of the canon. The recent researches of Edgar (39) have proved conclusively that the Egyptians used, in the course of ages, a succession of canons. The first, employed from the time of the Ancient Empire, divides an erect human figure over eighteen squares, the highest of which ends, not at the top of the head, but at the top of the brow, thus leaving the dome of the skull outside, as well as the head-dresses or crowns which the Egyptians monuments display in such great variety. The knee falls over the sixth square; the upper part of the legs over the ninth; the shoulders over the sixteenth; the nose over the seventeenth. The head, which occupies two squares, is thus one-eighth of the height of the rest of the body. Under the same system the sitting figure occupies fifteen squares, plus the dome of the head. Some good examples of figures drawn on squares may be seen in the tomb of Su-em-nut at Thebes. (40). Reference may also be made to an example of figures with guiding lines in the tomb of Akhethetep at Saqqara. (4 I)

The second canon, which is principally used from Saite times, although it may perhaps be met with from the time of the Ancient Empire, shows more elongated figures : the erect figure is divided over a much greater number of squares. The top of the brow is a fraction over No. $2 \mathrm{I}$; the mouth at 20 ; the shoulders at 19 ; and the knees at $7 \cdot(42)$

Various authors have attempted to discover the basis of these canons. Lepsius sought for it in the length of the foot; Wilkinson in the height of the foot; C. Blanc claims to have discovered it in the length of the medius.

It occurred to me to make investigations to see if in the 
numerous figures of offering-bearers, which show such variation in the position of the arms, these latter were drawn merely according to the fancy of the artist, or whether the various attitudes really followed any definite rule. I observed with surprise that if a circle be traced on the level of the elbow with the angle of the armpit as its centre, the different positions of the forearm around this circle coincide exactly with the width of the arm or with half this width. A similar result is obtained if the elbow is taken as centre, and the movement of the forearm noted. It corresponds always to a width equal to the thickness of the fist or to one-half of its thickness. (43)

The Egyptians must have used books of models in which the proportions were accurately indicated, and in which the decorators of a tomb could find a selection of figures and of attitudes detailed with precision. Fragments have actually been found, of late period it is true, of papyrus containing models of this kind. (44) Akin to these are the sculptors' models, of which several specimens are known perhaps already from the ancient kingdom (45), but more frequent from the time of the XVIIIth dynasty, $(46)$ and which are particularly usual in late times. We may refer to a few specially well-known examples : models of figures in relief of the XVIIIth dynasty at Munich (47) and at London, models of Saïte reliefs showing different states of work in the Cairo Museum ; figures of gods, animals and hieroglyphs, etc.

Various collections also contain sculptors' models in the round which show on the back and sides the division lines which Edgar has connected with the canons of proportion. (48) Finally, mention must be made of architectural models giving parts of buildings (for example, a column attached to the jamb of a doorway) or such details as a floral capital.

\section{BIBLIOGRAPHY.}

I. Carter, H., and Gardiner, A. H., The Tomb of Ramesses IV and the Turin Plan of a Royal Tomb, in the Fournal of Egyptian Archaology, t. iv., I917, Pp. I $30-58$, and pls. 29,30 . 
2. Daressy, G., Un Plan egyptien d'une tombe royale, in the Revue archéologique, t. xxxii., I 898, pp. 235-40.

3. Wreszinski, W., Atlas zur altägyptischen Kulturgeschichte, Leipzig, I9I 4 , pls. 73-5.

4. Davies, N. de G., The Rock Tombs of El-Amarna, Part I, London, I903, pl. $3 \mathrm{I}$.

5. Compare pl. 32 with a slightly different process.

6. Ibid., pl. 26.

7. Ibid., pl. I 8 .

8. Wreszinski, W., Atlas für altägyptische Kulturgeschichte. Leipzig, 1914, pl. 6.

9. Quibell, J. E., Excavations at Saqqara: The Tomb of Hesy, Cairo, I 913 , pl. 29.

I o. Compare the statue of Ti in Steindorff, G., Das Grab des $T i$, Leipzig, I 9 I 3 , pl. I42, with the relief in pl. 68.

I I. Lepsius, R., Denkmäler, Part II, pl. 2 I.

I 2. Pottier, E., Le dessin par ombre porté chez les Grecs, in the Revue des Etudes Grecques, t. xi., I 898, pp. 355-388.

I 3. Capart, J., Une Rue de Tombeaux à Sagqarah, Brussels, 1907, pl. 40.

14. Ibid., pl. 39. Blackman, A. M., The Rock Tombs of Meir, Part II, London, I9I 5, pl. 24.

I 5. Petrie, W. M. F., Les Arts et Metiers de l'ancienne Egypte, Brussels, I9I 2, fig. 74, p. 70. See, too, Davies, N. de G., Mural Paintings in the City of Akhetaton, in the Journal of Egyptian Archeology, t. vii., I92 r, pl. I.

16. Wreszinski, W., Atlas, etc., pl. 2.

1 7. Ibid., pls. I $0,89,90$.

I 8. Lepsius, R., Denkmäler, Part III, pl. 42 .

19. Wall Decorations of Egyption Tombs Illustrated from Examples in the British Museum, London, I9I4, pl. 4.

20. Rosellini, Monumenti storici, pl. 68.

21. Carter, H., and Newberry P. E., The Tomb of Thoutmôsis IV (Cat. Gen. du Musée du Caire), I904, pl. I I.

22. Wreszinski, W., Atlas, etc., pl. 26. See, too, Borchardt, L., Das Grabdenkmal de Königs Sahure, t. ii., Die Wandbilder, Leipzig, 1913, pl. I 7 .

23. Davies, N. de G., Rock Tombs of El-Amarna, Part II, London, I905, pl. 38 ; ibid., Part III, pl. I 3 .

24. Prisse d'Avennes, Histoire de l'art égyptien, Paris, I878, t. ii., pl. I8; Lepsius, Denkmäler, Part III, pl. 76.

25. Mariette, A., Voyage dans la Haute Egypte, Cairo, 1878, t. ii., pl. 48 See, too, Lepsius, Denkmäler, Part III, pl. 6I, and for Ramesses II, Rosellini Monumenti storici, pl. 79 .

26. Rosellini, Monumenti storici, pl. 96.

27. Ibid., pls. 74, 75 .

28. Wreszinski, W., Atlas, etc., pl. 8.

29. Paget, R. F. E., and Piric, A. A., The Tomb of Ptah-hetep, in Quibell, J. E., The Ramesseum, London, I 898, pl. 32 .

30. Steindorff, G., Das Grab des Ti, Leipzig, 1913, pl. I 24. 
3r. Wreszinski, W., Atlas, etc., pl. 3 .

32. Ibid., pl. 66.

33. Borchardt, L., Das Grabdenkmal des Königs Sahure, t. ii., Die Wandbilder, Leipzig, I9r 3 , pl. I7.

34. Davies, N. de G., The Tomb of Nakht at Thebes, New York, r 9 I7, pls. I 8 sqq., and p. 6I note. Prisse d'Avennes, Histoire de l'art égyptien, Paris, r 878 , t. ii., pl. 20 .

35. Breasted, J. H., The Battle of Kadesh, Chicago, I903.

36. Daressy, G., Notice explicative des ruines du temple de Louxor, Cairo, I 893, p. 26. One small part in Maspero, G., The Struggle of the Nations, London, r9I0, p. 273.

37. Wreszinski, W., Atlas, etc., pl. 2 r.

38. Lepsius, R., Proportionen in Grab des Ma-nefer, in the Denkmäler aus aegypten und aethiopien, Text, t. i., Leipzig, 1897, pp. 233-8.

39. Edgar, C. C., Remarks on Egyptian Sculptors' Models, in the Recueil de Travaux, t. 27, 1905, pp. 132-50; Sculptors' Studies and Unfinished Works (Cairo Catalogue), Cairo, r9o6.

40. Wreszinski, W., Atlas, etc., pl. 3r. See the study of E. Mackay, Proportion Squares on Tomb Walls in the Theban Necropolis, in the Journal of Egyptian Archeology, t. iv., 1917, pp. 74-85, and pls. I 5-8.

4I. Davies, N. de G., The Mastaba of Ptah-hetep, Part II, London, I 901 pl. 17.

42. Prisse d'Avennes, Histoire de l'art égyptien, Paris, I 878, t. ii., pl. 2.

43. See the figures of servants in Davies, N. de G., The Mastaba of Ptahhetep, Part II, London, I90 r, pl. 24, and the details on pls. 25-7.

44. Erman, A., Zeichnungen ägyptischer Kunstler grieschischer Zeit, in the Amtliche Berichte aus den Königlichen Kunstsammlungen, t. xxx., I909, No. 8, Col. 197-203, and figs. I I9-25. Borchardt, L., Sphinxzeichnungen eines ägytischen Bildhauers; ibid., t. xxxix., I918, No. 5, Col. ro5-rro, and figs. 34,35 .

45. Winlock, H. E., Bas-reliefs from the Egyptian Delta, in the Bulletin of the Metropolitan Museum of Art, New York, t. xii., I917, pp. 64-7, and 2 figs.

46. A great number found at 'Tell-el-Amarna and unfortunately not published before their dispersal. See Sale Catalogue of the Amherst Collection, London, Sotheby, I 92 I, Nos. 847-54.

47. Bissing, F. W., Denkmäler ägyptischer Skulptur, Munich, I 906, pl. I 24.

48. See the works of Edgar quoted above, No. 39, and recently Morgensen, M., Modeller og oversesstykker i Ny Carsberg Glypotek, in Fra Ny Carlsberg Glyptotekets Samlinger, Copenhagen, I 92 I, pp. I 5-38, with 33 figs. 


\section{CHAPTER XI}

\section{THE ARTISTIC IDEAS OF THE EGYPTIANS}

THE preceding chapters are intended to form a general introduction to the study of Egyptian art as a preliminary to the examination of its historical development. But this, in the present state of our knowledge, presents difficulties of which we must first convey a summary idea.

As a general observation, we may note that Egyptian art as a whole is known to us exclusively through archæological discoveries, and additions are made to various series of objects from year to year by the chance finds of excavators and under quite fortuitous conditions.

In so far as it is possible to study the architectural monuments which are preserved on the surface of the ground or recovered from the sands of the desert, or the innumerable objects of art exhumed from buildings or from tombs, archæologists have had to make the attempt to classify and understand them solely by their own exterior characters without any literary tradition whatever to aid them in the task. To speak briefly, it must always be regretted that Egypt has no Pausanias. This complicates the question of the æsthetic value by which Egyptian monuments have to be judged. Thus, we may possess numerous contemporary statues of one and the same king found in different temples, or, it may be, all in the same temple. It is impossible for us, in the absence of any literary indication-and unhappily the inscriptions on the statues themselves are absolutely mute on this point-to guess which pieces were considered the most beautiful or the best likenesses by contemporaries; nor can we tell which were the work of 


\section{ARTISTIC IDEAS OF THE EGYPTIANS I6I}

the same artist or which came from the same workshop, or even the same locality.

This is why we are scarcely in a position to answer a whole series of questions which arise: Did the Egyptians in the execution of their works of art bring those æsthetic considerations to bear which are characteristic of artistic work in modern times? What was the extent of their appreciation of the beautiful? What did they consider to be beautiful? Had they distinguished between the ideas of the beautiful and the good, the useful and the pleasant? If so, had they artists who aimed at the ideal, if not the realisation, of the beautiful ?

Alas! it is impossible to give exact replies to these questions, and as can be easily seen, they are questions of prime importance which all ought to be solved if we would pronounce any judgment of real value on Egyptian works of art. Without this judgment we run the risk of having to content ourselves in most cases with deciding how much in Egyptian art is in keeping with our own taste, rather than with being able to discern which works responded most fully to the end which their creators had in view.

It must not be expected to find all these delicate questions discussed here, for it would necessitate a vast accumulation of details and wide digressions. Consequently we must content ourselves with a few remarks merely to call attention to the existence of such problems, even though we cannot seek to clear them up entirely.

What was the end which the Egyptians had in mind in the production of their monuments? It is almost useless to repeat that the original purpose of architecture was essentially practical. Above all things, it was necessary to build houses for the living, for the gods, and for the dead : the first in light and temporary materials, the second and third in materials which were considered to be-in theory at leastimperishable. Diodorus has told us that the Egyptians called their houses inns and their tombs everlasting abodes. The Egyptian texts speak of the erection of temples " of millions of years" and of monuments and houses "for eternity." 
Curiously enough, the Egyptians were in the habit of giving proper names to their temples, or even to parts of a building-the door, for example. This leads us to believe that they considered the building as an animated being, or at least as animated by a living spirit. (I)

We have seen that the architectural forms are frequently due to technique, and also to ritual practices.

The interior arrangements correspond to the necessities of comfort or of special usages, and it is particularly noteworthy that in Egypt the house, the temple and the tomb present the most striking analogies. (2) When we study the plans of tombs, we observe therein somewhat strange complications which as a whole embody the idea of placing the dead in security from profanation-at lcast, conversely, the fear of the dead returning led the Egyptians to take special measures to prevent the dead from coming out. Practically all the royal tombs of the $\mathrm{Vth}$ and VIth dynasties were made upon the same plan, and the Arabs have pillaged them, one after the other, without hesitation. (3)

The fear of the dead actually does play a very important part in the funereal scheme of the ancient Egyptians. To see this we have but to refer to the incantations in the medical papyri, which are generally directed against the dead man or woman whose influence had produced the illness. (4) A great part of the funerary rites is derived from the desire to propitiate the soul of the dead-and even this in proportion to the terrestrial power of the deceased-and to procure for him in the tomb all that he could desire. In conformity with this intention, the Egyptians placed elaborate furniture and equipage in the tombs, which has to a great extent made it possible for us to reconstruct the material civilisation of Egypt. It was often considered enough to impart to the soul of the dead the illusion that it was possessed of numerous and abundant goods by the use of pictures, mostly painted or sculptured upon the walls of the tomb. (There is no essential difference, either from the point of view of purpose or of art, between the scenes painted in frescoes or sculptured in very light relief.)

The innumerable representations which we find upon 
the walls of temples and of tombs have then, above all, a religious or magical origin, an origin which, from the point of view of the living, is essentially practical. We must not be mistaken in the general character of the majority of these representations : even when they are placed upon the walls of a royal funerary temple they have not necessarily a personal character, and the commemoration idea, at least in the earliest periods, is not the dominating element in them. Thus, when we see an Egyptian king portrayed as the conqueror of all the neighbouring peoples of the Nile Valley, we are not thereby absolutely justified in drawing the conclusion that such and such a king made a raid into such and such a region. What it means-and this meaning is never lacking - is that the deceased king well knew himself to be irresistible, and that his appearance in any quarter of the world was tantamount to the complete submission of all possible enemies. It is true at times that these scenes really had a biographical significance; reliefs of this kind in the great temples of the New Empire are veritable pages from the annals in the strict sense of the word. We must beware, however, of any hasty generalisation, such as is often made in the cases of the tombs of private persons, whereby all reliefs and paintings are held to be a record of the life of the deceased. These paintings and bas-reliefs are not a reproduction of the life of such and such a noble or grandee. but rather a picture of a happy existence, considered in a general way, and of which the same episodes are faithfully copied from tomb to tomb-being nothing more than extracts from a book of models compiled as a standard of funerary decoration. (5) Here and there, and rarely, moreover, we come upon certain episodes which partake strictly of a biographical character. In such cases the idea is not so much to convey to posterity the pompous memory of an important event as to preserve for the benefit of the soul the remembrance of a glorious moment in its terrestrial existence.

If the majority of architectural monuments are dwellings inhabited by the spirits of the gods or of the dead, the real host of these buildings is the statue. Indeed, the Egyptian 
statues are living, they are " animated" in the etymological sense of the term; that is to say, imbued with the soul which has gained its entry by means of magical formulæ; the physical needs of a body of flesh and blood were accorded to them, and every care was taken to satisfy them.

A theological text from Memphis defines clearly the conception which was held of divine statues. (6) It is said of the god Ptah : "He fashioned the gods, created their cities, founded their provinces; he established the gods in their sanctuaries, and caused offerings of bread to be made to them; he founded their sanctuaries, he fashioned their bodies to the satisfaction of their hearts, and then the gods entered into their bodies of all kinds of wood, of stone and of metal." Nothing could express more clearly that when a body was fashioned in wood, stone or metal, the form of which is pleasing to the will of the divinity, the divinity comes and presides therein, in order to live in the sanctuary and to enjoy there the offerings which were renewed from time to time by periodical sacrifices. There is evidently an echo of this conception in the audacity of certain Egyptian conjurations which threaten the god who remains deaf to invocations with being deprived of what is necessary to nim in his sanctuary and with being allowed to die of hunger. This is, indeed, tantamount to affirming that the god is vulnerable in the person of his statue-body enshrined within the temple. (7)

It would be difficult to believe that the Egyptian kings considered that they animated the statues which portrayed them even during their lifetime, did we not know that they enjoyed the privilege, in common with the gods, of having several souls, any one of which could perfectly well incorporate itself in a statue. On more than one occasion kings have erected sanctuaries where their own statues, together with those of the gods, were the object of a special cult rendered by the king himself. Thus Ramesses II speaks of the monument which he set up for his living image in the land of Nubia. (8)

Royal statues were given a special name, which imparted a particular attribute to them, for we know that the Egyptians 


\section{ARTISTIC IDEAS OF THE EGYPTIANS I65}

considered the name as a sort of spirit enjoying a separate existence.

We are informed by the priestly decrees, which are principally known from those of the Ptolemaic period, that royal statues or groups of statues destined to receive divine honours were consecrated even during the lifetime of the kings they represented. (9) The decrees of Rosetta and of Philæ in the name of Ptolemy $V$ make the following assertions: First, in all the principal temples in the land a group is to be set up, representing the king receiving from the principal local god the sword of victory called "Ptolemy the Avenger of Egypt " ; secondly, in each of these places a wooden image of the king shall be kept in a sanctuary of gold of a particular form, and carried in processions with the other sanctuaries of this kind ; thirdly, the nobles shall have the right to possess in their houses a sanctuary with its statue and to participate in the festivals; fourthly, a statue of the queen shall be placed beside that of the king, receiving the sword from the local god; fifthly, the wooden image of the queen shall be associated with that of the king in the sanctuaries and processions; sixthly, the nobles shall likewise have the privilege of paying homage to the statues of the royal couple in their own houses.

The kings delighted to collect specimens of their effigies in certain temples, arranging the statues, for example, between the columns of one court as at Luxor.

Certain statues had particular forms which were directly connected with the offerings made to the gods. Thus a king holds in his hands an offering-table, or a cult-emblem, or other objects. (IO)

The benefits attaching to such consecration of statues seem to have been so efficacious that the kings did not hesitate to usurp the statues of their predecessors in order to appropriate for themselves both the merit and the profit. (I I) This habit, which seems somewhat shocking to our modern conceptions, sometimes raises difficulties as to the attribution of a work of art to such and such a sovereign or to such

and such a period. Thus it is known that monuments of the Ancient Empire were usurped by the Hyksos and then 
by the kings of the XIXth, and finally by those of the XXIst, dynasty. (12) Private persons of high rank followed the royal example in this respect, and we may refer to the strange case of a priest of Amon of the XXIInd dynasty who has left for us at Karnak four statues, of which two, which go back to the XIIth dynasty, have been purely and simply adapted for their new owner by means of inscriptions. (1 3)

A certain number of royal statues found in the temples had a funerary purpose. The souls of the dead kings came to animate them, or rather they found there a haven wherein to participate within the temple in the life of the guests of the gods.

It would seem that certain sovereigns sometimes consecrated a series of statues representing their ancestors. These images were carried in processions. (14) The funerary statues which were set up in the temples were replicas of those deposited in the tombs. (1 5) From numerous texts and from detailed scenes we learn that during the funeral ceremony the statues were made to play their part by the enactment of a magical rite known as "the opening of the mouth," and which was destined to unite the soul to its body for all eternity, and to endow the latter with the power of exercising all the functions of a body of flesh and bone. (I6)

$\mathrm{Up}$ to the present no representation has been found of the making of royal funerary statues, although, on the contrary, we meet with bas-reliefs depicting the preparation of funerary statues both in wood and in stone of private persons in several places. They were made at the same time as the rest of the funerary gear, with the furniture if of wood, and with the stone vases if of stone. (17) This would seem to indicate that there was no thought of making them a long time in advance, besides taking into account that it might perhaps be harmful to the individual they represented to prepare them before the time they could assume their magical functions in the temple or the tomb. Private individuals, in addition to the " statues of the double," as they are called, shut up in a tomb, could obtain permission by royal favour to place one or several statues in the temples of the gods. (I 8) It was seen that the Egyptians held it to be dangerous 
to make the statue in advance, for they were aware that modelled figures could be put to criminal uses; this is known, for example, from the Lee papyrus, which narrates that an Egyptian was sentenced to capital punishment for having made certain wax figures which might have served to cast a spell against the person of the sovereign. (I9) We may add in passing that the popular tales of the Egyptians afford numerous episodes in which wax figures of men or of animals became alive and responded to the commands or to the magical power of the magicians. (20)

Thus it will be understood that Egyptian statues might be considered to be, primarily, living bodies, animated by the spirits of a god, or of a man-generally of a dead manand it will therefore be appreciated that such a conception as this could modify the artistic point of view profoundly. Moreover, certain statues, made for the funeral ceremonies, were often hidden away for all eternity, shut in as they were by the masonry of that part of the tomb which is known as the "serdab." The sculptor of statues of the most ancient times appears to us not so much as an artist as a specialised workman, the assistant of the funerary priest, contributing by his skill to the successful conclusion of the ritual ceremonies which were indispensable for assuring to the deceased a continued existence beyond the grave. The success of this issue depended in a large measure upon the degree of perfection of the sculptor's work, since the body of wood, stone or metal had to be befitting to the soul of the dead, just as it was necessary in order that the divine statue should receive the soul of the god.

We may perhaps ask, At what moment does the sculptorcraftsman become an artist? Theoretically there are two stages in his activity: First, he strives in the first place to make from his model as exact a copy as possible, with a purely and exclusively religious or magical end in view ; secondly, he interprets a natural type, in conformity with a determined ideal of beauty. The transition from one stage to the other is extremely subtle, and quite exceptional circumstances would be required for us to perceive it. We can note a well-marked tendency towards idealisation of features under 
the Ancient Empire, which implies a conception of beauty. If we enter the studio of an XVIIIth dynasty sculptor at Tell-el-Amarna to inspect there the studies from life in course of execution, we can see in what manner he succeeded in interpreting nature by following a preconceived determination. In this case we are really in an artist's studio, and not merely in the workshop of a manufacturer of statues. (2 I)

Without entering into a consideration of the difficult problem of æsthetics, we may inquire whether it is not possible for us by a few simple facts to gather something of what we might call the sense of beauty in the Egyptians. The Egyptians were passionately fond of flowers, although the flora of Egypt is not a rich one. The lotus was employed in many different uses : on feast-days the Egyptians hung garlands of it from the walls, they tied it on to the cornices of kiosks and canopies, wound it round vases, and made collars and crowns of it. Decorative art here had but to copy habitual forms to produce fixed schemes of decoration in great abundance. (22) Jewellery long remained faithful to the forms which are offered by nature, as rich as they are simple.

Is it not to this love of flowers that the taste for brilliant and gaily coloured materials is due, a taste which manifests itself in those pieces of jewellery which are called " incrustations," in furniture combining materials of different colours, or in tapestry and matting of many various forms?

It is scarcely necessary to enlarge upon the charm which gathers round these feminine, elegant and gracious forms. Industrial art particularly has produced in this direction some remarkable types, which transform an object of common utility into something really fine, or at least pleasing to behold. When the ancient craftsman gives an unguentholder the form of a girl carrying a vase on her shoulder, (23) or of a swimmer who clutches at a duck, he evidently has more in mind than merely making for his customer an unguent-holder. The primary purpose has almost disappeared, and the maker's talent is concentrated on producing a pretty object to tempt the fair lady whose artistic taste is thereby revealed. Thus we have here an artist who 
creates the beautiful and, what is equally important, a clientèle which seeks artistic work. (24) If the Egyptians produced grotesque figures, such as those of the god Bes or of captive foreigners, their intention was to provoke ridicule, or to emphasise by contrast the superiority of gracious and beautiful forms.

We must not omit to take into account the part played by commerce in the development of the artistic sense of the Egyptians, particularly under the New Empire. We actually see neighbouring tribes bringing objects of industrial art as tribute. We must be cautious in using this argument, for certain facts show that the Egyptians sometimes represented, amongst the objects brought as tribute by foreigners, furniture and utensils obviously manufactured in Egypt out of raw material imported from tribute states. It is impossible to deny the influence exerted by the relations between Egypt and the Ægean peoples, (25) although it is probable that Egypt gave more than she received.

Let us refer for a moment once more to the general importance of the productions of industrial art, for it is these that have necessarily the greatest diffusion amongst the mass of the population. One might judge of the part played by artistic notions among a people by the everincreasing extension amongst the most diverse social classes of æsthetic considerations. Now in Egypt, when we examine the collars, or adornments in general, the stone vases, the ceramic vases, we shall observe that not a single form is due to mere chance. We perceive in the industries of all periods unmistakable tendencies, which, whilst preserving the general forms of the objects, modify and change them according to the occasional caprices of fashion and taste. We have already observed this in ancient times as affecting the fundamental ceramic types.

The king and his courtiers set the fashion; the influence of the capital, inasmuch as it was the court residence, always predominated in ancient Egypt. As a result of this, conditions necessary to the formation of real and distinct schools of art never existed in Egypt. Furthermore, we can observe that the various provincial towns were not always equally 
successful in their attempts to imitate the productions of the capital. Through lack of artists trained in the art traditions of the court, local artists had to suffice, and their productions are but faint echoes of the royal works which served as their models. (26)

The texts convey quite definite information as to the direct intervention of the kings in the execution of the monuments. They represent the sovereign in his own domain, inspired with the idea of improving or embellishing the buildings belonging to the gods or to the dead. (27) It is he who busies himself with the foundation, restoration, or enlargement of the temples. (28) We see the Pharaohs visiting works in progress and bestowing their approval upon the architects in charge. (29) The kings granted tombs to their favourites, and gave orders for the necessary stone, which was conveyed by the great barges which belonged to the court. (30) The Pharaoh Sahure, of the Vth dynasty, had two stones, which were destined for the tomb of a favourite, brought to the palace itself, where they were worked, sculptured and painted under the daily superintendence of the two high-priests of Memphis and their staff. (3I) When victorious military expeditions flooded Egypt with the tributes of the vanquished peoples, the king seized the opportunity to make artistic gifts to the temples, for example, in the shape of complex goldsmith's work. In a list of objects of this kind engraved upon a wall at Karnak, an inscription notes that certain vases were executed according to "the express desire of His Majesty." (32) Objects of art are likewise given by the king to great personages as a mark of satisfaction: the Louvre preserves, for instance, some engraved cups in gold and silver, given by Tuthmosis III to a functionary of the XVIIIth dynasty. (33)

The king also considered it a duty to preserve the traditional artistic forms : a stele of Neferhotep of the Middle Empire shows us the sovereign busying himself with a search amongst the ancient writings in order to ascertain what were the forms proper to divine images. He betakes himself to the priestly libraries to pore over the ancient books, and he expresses his desire to execute the statues 
in accordance with such directions as he might find in the documents. (34)

The Pharaoh also boasts of the care he takes to maintain artists. A stele of the 8 th year of Ramesses II, found at Heliopolis, tells us how, on the occasion of a visit to Heliopolis, the king in a walk among the mountains discovered an enormous block of granite, higher than an obelisk. (35) His Majesty issued the order to have it worked " by skilled artists of sure hand." The work lasted a year. "Behold, His Majesty rewarded the overseer of the work by much silver and gold, and the worthy artists who had laboured upon it by royal praises, for His Majesty inspected it day by day; and they, moreover, worked for His Majesty with hearts full of devotion for Ramesses II." The king then found a fresh quarry, from which he had numerous statues made, upon which he pronounces a long discourse to the artists and masons engaged upon the work. He praises their skill, their activity and their devotion to duty, in making statues which are destined for the temples and thereby to everlasting duration. The king, for his part, is not lacking in appreciation, and assures his workers that their needs will be well provided for and abundant supplies of meat, drink and raiment allotted to them, for he realises that enthusiasm can only grow upon " a full stomach." Indeed, the greater part of the inscription is devoted to a long enumeration of the gifts of necessities and of luxuries which the grateful sovereign will heap upon his sculptors as a reward for their energy and skill.

It is a striking fact that no sculptor's or artist's name is mentioned throughout this text. One might say in general terms that all Egyptian art is anonymous; the king only exists, and it is to him that the credit is accorded for the conception of the great monuments which he caused to be executed under the superintendence of functionaries called " overseers of the king's works," and who were at the same time invested with a whole series of other functions-political as well as military or sacerdotal. A certain number of biographical inscriptions provide us with interesting details of works thus executed by order of the king : we have noted 
some examples when speaking of the working of the quarries. (36)

Signed statues are extremely rare, (37) and it is only quite exceptionally that one can attribute several contemporary statues to a single name. Two sculptors of the time of Amenophis IV are known, thanks to a bas-relief which they have left in a quarry at Assuan, whilst the statues they made have disappeared. (38) A bas-relief at Tell-el-Amarna represents a sculptor's studio in full activity. (39) Several cases can also be quoted in which the name of a sculptor or of a painter who decorated such and such a tomb can be determined with some precision. (40) In the tomb of Prah-hetep at Saqqara, for instance, the author of the basreliefs is himself represented in one of the scenes. (4 I)

Art-teaching was probably carried out in the schools attached to the temples, where all the traditions of the profession were learned. The young draughtsman and sculptor, by a systematic training, was made to assimilate his rules and to copy his models. This obviously left very little scope for initiative, and the study of Egyptian art as a whole, moreover, shows that relatively little was done in the way of innovation in the course of the ages. One was reared from the earliest times upon a rich store of traditions, whose origins stretch back into the far-distant past. On the other hand, it is undeniable that the very constitution of this complex of forms and models can only be explained by a period of very intense artistic research which we are forced to carry back to the very beginning. Before it could be determined, for example, what was the best form to adopt in order to depict an owl, it must have been necessary to make a certain number of studies from nature of the owl, and one cannot mistake the exceptional importance of the part played by hieroglyphic writing in the fixing of forms.

It would be very desirable also to be able to examine the extremely interesting question of the traces left by the xsthetic ideas of the Egyptians in their language, but it is a vast and difficult subject, on which we can only make a few rapid remarks. In this connection it is interesting to note that the high-priests of Ptah were placed in direct 
relationship with art. We have already seen them occupied, under the direction of the king, with the execution of monuments. The literal translation of their title is "the great chief of the work," the word "work" being written with the sign which represents the particular tool which the Egyptians used for carving hard stones. (42) The word "workman" employs the same sign, and the word "art" likewise. Edward Meyer has suggested an attractive explanation of this fact. As the quarries of Toura, near Memphis, formed part of the temple property of Ptah, this god began by being the protecting deity of the stoneworkers and sculptors exploiting these quarries; hence, little by little, he became the patron of artists. (43) This would have been facilitated by the fact that the development of art under the Ancient Empire was limited to Memphis, the royal residence. The word "art" is likewise used in speaking of the functions of the priest who carries out the funerary rites. (44) Might it not, therefore, be supposed that the Egyptians attributed to the exercise of the arts a mysterious virtue similar to that possessed by ritual formulæ ?

The word which we generally translate by " monument" is connected with the root " to endure " or " to last."

The word "scribe" likewise is used to express the idea of "draughtsman" or "painter." When it was desired to set up a stele or statue, the first to be called upon were the scribes of "the house of life," by which is meant the priestly library, the college of priests, or even the university. (45)

One of the words for sculptor is identical with that for " smith." (46) Another designation of the sculptor is " he who makes to live." "To make a statue" could be expressed by using the verb mes, which means " to give birth " or "beget." The name of the King Tutankhamon literally means "the living statue of the god Amon." The word " copy" is also used to express " statue." To dedicate a statue or even a tombstone to anyone is called in Egyptian "to make his name live."

One and the same word is used to signify a "marvel," a "prodigy," and a "stone-quarry." The radical shepses, which is often employed to express the idea of " magnificent or 
luxurious objects," is employed equally for the noun "statue," or for the verb "to work in stone," and the hieroglyph itself seems to depict a stone statue. The radical $i a k h$, of which one of the fundamental senses is "to be a spirit," serves to convey the ideas of "brilliant," " excellent," " useful," " propitious," " pleasant." The radical zeser signifies "lofty," and also " superb," " precious," "well planned," "well done." Finally, the word nefer means "beautiful," but at the same time "good " and " agreeable." The Egyptian language does not appear to have drawn the sharp distinctions which are necessary for the creation of a terminology suitable for conveying clear and defined æsthetic ideas.

\section{BIBLIOGRAPHY.}

I. See for example the names of many of the doors in the temple of Amon at Karnak, in Mariette, A., Karnak, Leipzig, I875, pl. 38 and p. 58.

2. Steindorff, G., Hous und Tempel, in the Zeitschrift für ägyptische Sprache, t. xxxiv., I 896, pp. I07-I I, with 2 figs.

3. Maspero, G., Premier Rapport à l'Institut d'Egypte sur les fouilles executées en Egypte de I88I $\dot{a}$ I 885 , in the Études de mythologie et d'archoologie égyptiennes, t. i., Paris, I893, p. I5 I ; ibid., Les Inscriptions des Pyramides de Saqgarah, Paris, I894, p. 2.

4. Maspero, G., Causeries d'Egypte, Paris, 1907, pp. 229 sqq.

5. Nothing is more characteristic than the scenes curtailed by want of space with an explanatory text betraying the actual process of shortening. See Erman, A., Reden, Rufe und Lieder auf Gräberbildern des alten Reiches, Berlin, 1919, p. 3 I, No. 2, and p. 32, No. 7.

6. Erman, A., Ein Denkmal memphitischer Theologie, in the Sitzungsberichte der Königlich preussischen Akademie der Wissenschaften, Berlin, t. rliii., I 9 I I, P. 942.

7. Erman, A., Die ägyptische Religion, 2nd edition, Berlin, I909, pp. 172-3; Grapow, H., Bedrahungen der Gotten durch den verstorbenen, in the Zeitschrift, t. 49, I9I I, pp. 48-54; see, too, Pleyte, W., Étude sur un rouleau magique du Musée de Leide, Leiden, I 866, pp. I76 sq9.

8. Brestead, J. H., Ancient Records of Egypt, Chicago, 1906, t. iii., \$502, p. $2 \mathrm{I} 4$.

9. Sethe, K., Zur Geschichte und Erklarung der Rosettana, in the Nachrichten von der K. Gesellschaft der Wissenschaften zu Göttingen: Philologischhistorische Klasse, 1916, pp. 275-314.

I0. Pictures of such statues are given in Caulfield, A. St. G., The Temple of the Kings at Abydos, London, I902, pls. 4, 5, and I 5 .

I I. Daressy, G., Deux grandes Statues de Ramse's II, in the Annales du Service des Antizuités, t. xvii.,, 1917, p. 35; Maspero, G., Trois Statues colossales, in the Musée Egyptien, t. ii., Cairo, 1907, pp. 38-9. 


\section{ARTISTIC IDEAS OF THE EGYPTIANS 175}

12. Capart, J., Les Monuments dits Hycsos, Brussels, r9i4. See another example in Daressy, G., L'Art Tanite, in the Annales du Service, t. xrii., I9I7, p. 170 .

i3. Legrain, G., Statues et statuettes des rois et de particuliers, t. iii., Cairo I 914 , pls. I $3-17$.

I4. Rougé, E. de, Étude des Monuments du massif de Karnak, in the Mélanges d'archaologie égyptienne et assyrienne, t. i., I872, p. I 3 I ; Maspero, G., Histoire ancienne des peuples de l'Orient classique, t. i., Paris, I895, p. 233, No. I. See Lepsius, Denkmäler, Part III, pls. I6 3 and 2 I $3 a$.

I 5. Maspero, G., Le Double et les statues prophétiques, in the Etudes de mythologie et d'archéologie égyptiennes, t. i., Paris, I 893, pp. 77-9I.

16. Maspero, G., Le Rituel du Sacrifice funeraire, ibid., pp. 283-324.

17. Klebs, L., Die Reliefs des alten Reiches, Heidelberg, I91 5, pp. 81-82; Steindorff, G., Das Grab des Ti, Leipzig, I 9 I 3, pls. I 33, I 34.

I 8. Maspero, G., De quelques documents relatifs aux statues des morts, in the Etudes de mythologie, etc., t. i., Paris, r 893, pp. 53-75.

r9. Newberry, P. E., The Amherst Papyri, London, r 899 , Papyrus, No. V., pp. I 9-22.

20. Maspero, G., Popular Stories of Ancient Egypt, London, I91 5, pp. 25, I 26, I 59 .

21. Borchardt, L., Ausgrabungen in Tell-el-Amarna, I9I2-13, in the Mitteilungen der deutschen Orient-Gesellschaft, No. 52, October 191 3 ; Führer durch die Austellung von Funden aus der Ausgrabung I9 I 2-I 3, in Tell-el-Amorno Berlin, I9r3; Excavations at Tell-el-Amarna, in the Smithsonian Report for I9r 5, pp. 445-57 (reprinted, Washington, I92I). See the splendid plates in Fechheimer, H., Die Plastik der Aegypter, Berlin, $192 \mathrm{r}$.

22. Jéquier, G., Décoration égyptienne: Plafonds et frises végétales du nouvel empire thébain, Paris, I $9 \mathrm{r}$.

23. Prisse d'Avennes, Monuments Egyptiens, Paris, i 847 , pl. 48 .

24. Capart, J., L'Art et la parure féminine dans l'ancienne Egypte, in the Annales de la Société d'archéologie de Bruxelles, t. xxi., I 907, pp. 305-34.

25. Fimmen, D., Zeit und Douer der kretisch-mykenischen Kultur, Leipzig, 1909.

26. Kees, H., Studien zur ägyptischen Provinzialkunst, Leipzig, 1921 ; the new scene described, pp. 6, 7, is known by a tomb in the Memphite necropolis ; Daressy, G., Le Mastabo de Mera, Cairo, r898, p. 546.

27. See as an example the stele of Aahmes in Ayrton, E. R., and others, Abydos III, London, I904, pl. 52.

28. Lefebure, E., Rites égyptiens. Construction et protection des édifices, Paris, I 890 ; Baillet, J., La Régime pharaonique dans les rapports avec l'évolution de la morale en Egypt, Paris, I9 I3, t. i., pp. 59-65.

29. Breasted, J. H., Ancient Records, t. i., Chicago, 1906, \$\$242 sq?.

30. Ibid., $\$ 2$ 10 sqq.

3 r. Ibid., $\$ 237$ sqq.

32. Ibid.

33. Birch, S., Mémoire sur une patère égyptienne du Musée du Louvre (translated by Chabas), in Chabas, F., Euvres diverses, t. i., Paris, r 899, pp. 225-74; Vernier, E., La Bijouterie et la jocillerie égytiennes, Cairo, 1907, pl. 20. 
34. Breasted, J. H., Ancient Records, t. i., Chicago, 1906, \$\$ 753 sqg.

35. Ahmed bey Kamal, Stéle de l'an VIII de Ramsès II, in the Recueil de Travaux, t. $x \times x$., I 908, pp. 213-I 8. [I have paraphrased the inscription on this stele for the English edition, as the sequence of ideas and the peculiar method of phraseology in a literal translation of the Egyptian text cannot be happily expressed in modern English.-TRanslator.]

36. See also Breasted, J. H., Ancient Records, t. ii., Chicago, 1906, \$3 35 s99. and 372 sq9.

37. Legrain G., Statues et statuettes de rois et de particuliers, t. i., Cairo, 1906, pl. 75 and p. 78 .

38. Bissing, F. W., Denkmäler zur Geschichte der Kunst Amenophis IV, Munich, I9I 4, pl. I.

39. Davies, N. de G., The Rock Tombs of El-Amarna, Part III, London, 1905, pl. I 8 ; see Legrain, G, Trois Monuments de la fin de la XVIIIe dynastie, in the Musée Egyptien, t. ii., Cairo, 1907, pp. I sq9.

40. Erman, A., Bilder der Jahreszeiten, in the Zeitschrift, t. 38, 1900, pp. 107-8; Ein Maler des neuen Reiches, ibid., t. 42, 1905, Pp. I 28-3I ; Maspero, G., Notes de Voyage, $\$ X X I$, in the Annales du Service, t. xi., I 9 I I, pp. I 58-9; Röder, G., Namensunterschriften oon Kunstlern unter Tempelreliefs in Abu Simbel, in the Zeitschrift, t. 50, 1912, pp.76-8; Spiegelberg, W. Der Maler Heje, ibid., t. 54, 1918, pp. 77-9; Ein Kunstlerinschrift des neuen Reiches, in the Recueil de Travaux, t. 24, 1902, Pp. I 85-7; Steindorff, G., Das Lied aus Grab, in the Zeitschrift, t. 32, 1894, p. I 26.

41. Erman, A., Ein Kunstler des alten Reiches, in the Zeitschrift, t. 31, I 893, pp. 97-8 and pl. 2, with remarks by K. Sethe, ibid., pp. 99-100.

42. Quibell, J. E., Making of Stone Vases, in the Musée Egyptien, t. iii., Cairo, 1909, pl. 22 and pp. 25-7.

43. In Stolk, M., Ptah. Ein Beitrag zur Religionsgeschichte des alten Aegyplens, Berlin, I 91 I, p. I3.

44. Capart, J., Une Rue de Tombeaux à Sapgarah, Brussels, I907, pl. 22.

45. Capart, J., Un Roman vécu il y a $X X V$ siècles, Brussels, 1914, pp. I6I 7 ; Griffith, F. Ll., Catalogue of Demotic Papyri in the Fohn Rylands Library Manchester, I 909 , t. iii., p. $8 \mathrm{I}$.

46. See contra Sethe, K., Die angeblichen Schmiede des Horus von Edfu, in the Zeitschrift, t. 54, I918, pp. 50-4. 


\section{INDEX}

Abydos: Temple of Seti I-

Abnormal pillars in, I I 2

Shrine-decoration in, 86

Shrine in, 75

Shrine of Ptah in, 76

Fsthetics, I60, 172

Amru, description of Egypt by, 18

Arches (see also Vaulting)-

Various kinds in brick, $9 \mathrm{I}$

Art, Egyptian-

Anonymous, 171

Commemorative use of, $\mathrm{I}_{3}$

Religious and magical use of, r 62

Royal patronage of, 170

Teaching, 172

Beni-Hasan, tombs of, 36

Borchardt, L.-

On origin of columns, 13 t

Bricks-

Method of laying, 90

Plastering of, 92

Vaulting in, $9 \mathrm{I}$

Building materials-

Bricks, 90

Combination of different, 96

Metal, 95

Mud, 89

Stone, 93

Various, 95

Wood, 92

\section{Burials-}

Archaic, at Diospolis, 45

Early Nubian, 48

\section{Canopies-}

Berlin Museum, 76

Tell-el-Amarna, 77

\section{Ceilings, 107}

Choisy, A.-

On building appliances, too
Chronology, Egyptian, 40

Table of various systems, 42

Columns-

As cult objects, 132

Derived from sceptres, 133

Fasciculated, I2 I

Floral capitals, 124

Hathor-headed, 127

Inverted bells, 127

Isolated, 135

Lily, $\mathrm{I}=6$

Lotus, II7

Multiple capitals, I27

Origin of, I 31

Palm, 126

Papyrus, 120

Varieties of, at Philæ, I 25

Crane, use of, 100

Cupola-

In tomb at Abydos, 92

In tomb at Thebes, 92

Dad-column, 133

Dad-emblem, 85

Deir-el-Bahari-

XIth Dynasty Temple--

Shrines in, 85

Deir-el-Bahari, Great Temple--

Classic effect, 37

Hathor shrine in, 77

Ogee in, 92

Polygonal pillars in, 1 I 2

Transport of obelisks, $9^{\$}$

Destruction of monuments-

Causes of, 33,138

Doorways, 106

Drawing, conventions of, I 45

Dressing of stonework, 97

Dynasties, Egyptian-

Table of, 28 
Enamel, early, 60

Derived from copper, 60

Excavation-

Ancient methods of, $9^{6}$

Falcon-

Drawing of, 34

Fashion in Art, 169

Figures-

Archaic, 5

British Museum, ivory, $5^{\circ}$

Brussels Museum, 50

Early faïence, 60

Grouping of, 151

Oxford Ivory, 59

Flint implements, $5^{\circ}$

Flowers, Egyptian love of, 168

Foundations, 97

Furniture-

Chair legs from Naqada, 60

Chair legs from Abydos, 60

Gaming picces, 59

Gargoyles-

Ancient use of, 108

Griffith, F. Ll.-

On architectural hieroglyphs, 74

On arrangement of dynasties, $3 \mathrm{I}$

On origin of hieroglyphic writing, 61

Ground-level, changes in, 106

Hathor emblems, 134

Hathor heads, I 13

Hemispeos, definition of, 96

Hesi-

Gaming-pieces in tomb of, 59

Panels of, 34

Hieroglyphic writing-

Origin of, $6 r$

Hierakonpolis-

Monuments of Khasekhemui, $5^{\mathrm{S}}$

Royal tomb at, 52

Wall-decoration at, 52

Hieroglyphs-

Architectural, 74

Importance of, in Art, 70

House, Theban painting of, 137

Human form-

Conventional drawing of, 149

Proportions of, 155

Somctimes quite accurate, $15^{\circ}$
Imitative monuments, 64

Inundation, 2 I

Ivory knife-handles-

Cairo Museum, 53

Louvre, 65

Jewellery-

Dashur, 36

Illahun, 36

Karnak-

Size of hypostyle hall, 37

Kauit, sarcophagus of, 85

Khasekhemui, King-

Monuments of, $5^{8}$

Khephren, mask of, at Leipzig, 35

Temple of, 34, 98, ro9

Iandscape drawing, 154

Legrain, G.-

Repairs to Karnak temple, 99

lighting-

Appliances for, 108

Lotus-

Different kinds of, I 17

Manetho, 27

Maspero, G.-

Arrangement of dynasties by, 30

Description of Egypt by, 19

On Memphite Art, 66

Mastabas, 35

Matwork-

Architectural imitation of, 82

Meroitic pottery, 49

Metal-work, rarity of, $13^{8}$

Meyer, E.-

On pre-dynastic kings, 62

Models-

Papyrus containing, I 57

Sculptors', 157

Naqada-

Royal Tomb-

Construction of, 57

Pilasters and niches in, 67

Narmer, palettc of, 33

Details of, 57

Nile gods, 68

Obelisks, 132

Palermo stone, 27 
Palettes-

British Museum, 64

Cairo Museum, 65

Designs on, 64

Louvre, 64

Narmer, 33, 57

Slate, 53

Papyrus, Anastasi No. I-

Technical problems in, 99

Papyrus columns, 120

Papyrus plant-

Different kinds of, 120

Pepi I, metal statue of, 35

Perspective, ${ }^{1} 5^{2}$

Petrie, W. M. F.-

Chronology of, 42

Dating by sequence dates, 46

Discoveries at Diospolis, 45

Matwork from Tarkan, 7 I

Pharaonic monuments-

Earliest, $5^{6}$

Pillars-

General form of, $\mathrm{IO}_{4}$

Hathor-masks on, I I 3

Osirian, II4

Polygonal, in I

Proto-doric, 112

Square, 109

Plan-drawing, I45

Plans, Egyptian-

Of royal tombs, 145

At Tell-el-Amarna, $1+6$

Pottery-

"Boat" decoration of, 51

Dating of early, 46

Early Pharaonic, 56

Meroïtic, 49

Nubian, 48

Preservation of monuments-

Causes of, 32

Proportion squares, 156

Pylons, 105

Registers, use of, I 54

Renouf, P. Le Page-

On relation of words for "stele" and "seat," 82

Sarcophagi-

Stele designs on, 79

Sequence dates, 47

Serpent King, stele of, 34

Architectural designs on, 75

Description of, $5^{8}$
Sethe, K.-

On origin of hieroglyphic writing, 6 I

Shadouf, 23

Speos, definition of, 96

Statues-

Animated by gods or spirits, 164

Animated by kings, 164

Consecration of, $16_{5}$

Erected in temples, 165

Funerary, I 66

Groups, 14 I

Poses of, 139

Ptolemaic decrees on, 165

Technical details, 140

Steindorff, G.-

Arrangement of dynasties, by, $3 \mathrm{I}$

On origin of hieroglyphic writing, 61

Stelæ-

Egyptian word for, $8_{3}$

Simple and ornamented, 78

Simple, derived from shrine, 83

Reduplication of, 80

Stone-

Ancient records of quarrying, 94

Sources of various kinds, 93

\section{Tarkan-}

Ist dynasty, matwork from, 7 I

Technical processes, 98

Tiles-

Glazed, for walls, 92

Tuthmosis IV-

Designs on chariot of, $15^{2}$

\section{Vases-}

Early stone, $5^{\circ}$

Vaulting-

Brick, gI

Extensive use of, 9 I

Oldest in stone at Medinet-Mabu, 92

In temple of Es-Sebua, 92

In tomb of Ramesses IV, 92

Weight of stone monuments, 98

Windows, 108

Wood-

Foreign origin of, 93

Imitated in stone, 93

Use of, in building, 92

Use for inlay work, 93 
Printed in Great fintaim by

INWIN BROTHERS, LIMITED

LONDOX AND WOKING 




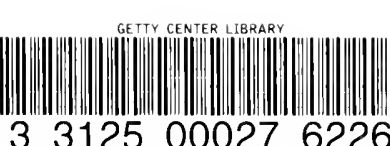




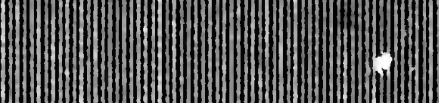

